\title{
Woody Feedstock 2018 State of Technology Report
}

\section{Damon S Hartley, David N Thompson, Hongqiang $\mathrm{Hu}$, Hao Cai}

September 2018

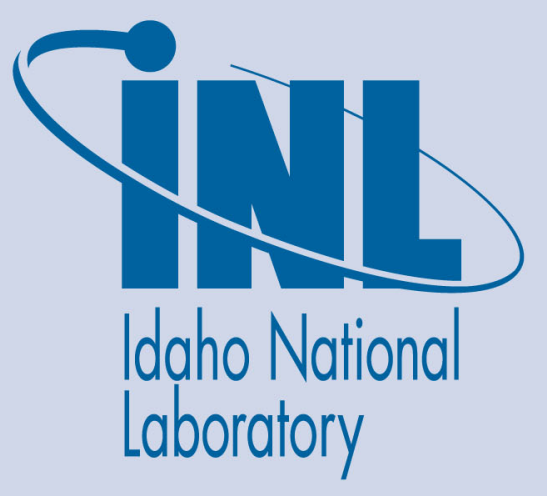

The INL is a U.S. Department of Energy National Laboratory operated by Battelle Energy Alliance 


\title{
Woody Feedstock 2018 State of Technology Report
}

\author{
Damon S Hartley, David N Thompson, Hongqiang Hu, Hao Cai
}

September 2018

Idaho National Laboratory Idaho Falls, Idaho 83415

http://www.inl.gov

Prepared for the U.S. Department of Energy

Office of Energy Efficiency and Renewable Energy

Under DOE Idaho Operations Office

Contract DE-AC07-05ID14517 


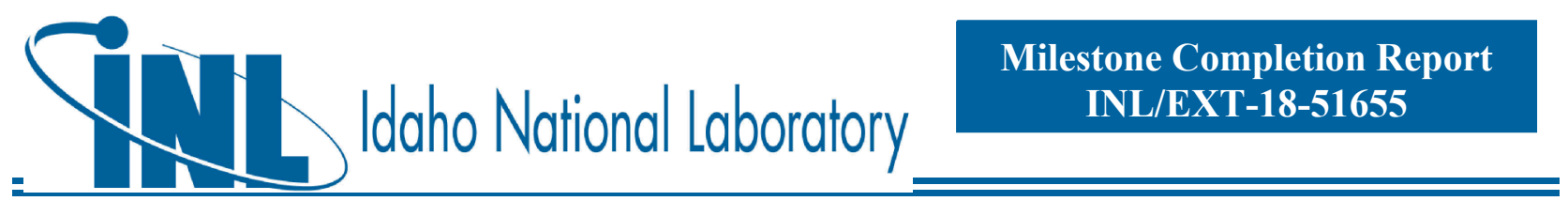

\section{WOODY FEEDSTOCK 2018 STATE OF TECHNOLOGY REPORT}

\section{Damon Hartley, David N. Thompson, Hongqiang Hu, and Hao Cai}

SEPTEMBER 30, 2018 


\begin{tabular}{|l|l|}
\hline BWD\#: 1.1.1.2.DL.1 & Completion Date: September 30, 2018 \\
Type: Milestone & Scheduled Completion: September 30, 2018 \\
WBS \#: 1.1.1.2 & Platform Area: Feedstock Supply and Logistics \\
\hline Milestone Title: & Woody Feedstock 2018 State of Technology Report \\
\hline Authors: & Damon Hartley, David N. Thompson, Hongqiang Hu, and Hao Cai \\
\hline $\begin{array}{l}\text { Project Name: Project } \\
\text { Leader: }\end{array}$ & $\begin{array}{l}\text { Feedstock Supply Chain Analysis } \\
\text { David N. Thompson }\end{array}$ \\
\hline Participating Researchers & $\begin{array}{l}\text { Tyler Westover, Neal Yancey, Jaya Tumuluru, Jeffrey Lacey, David } \\
\text { Thompson, and Vicki Thompson }\end{array}$ \\
\hline Key Words: & analysis, state of technology, feedstock, woody \\
\hline
\end{tabular}

\section{EXECUTIVE SUMMARY}

The U.S. Department of Energy promotes production of advanced liquid transportation fuels from lignocellulosic biomass by funding fundamental and applied research that advances the state of technology (SOT). As part of its involvement with this overall mission, Idaho National Laboratory completes annual SOT reports for biomass feedstock logistics. The purpose of the SOTs are to provide the status of feedstock supply system technology development for biomass to biofuels, based on actual data and experimental results relative to technical targets and cost goals from specific design cases.

The 2018 Woody Feedstock SOT presents the State of Technology for feedstock supply to three individual thermochemical conversion pathways that utilize woody feedstocks: Indirect Liquefaction (IDL), Catalytic Fast Pyrolysis (CFP), and Algal-blend Hydrothermal liquefaction (AHTL). The 2018 reactor throat delivered feedstock costs were found to be $\$ 63.76 /$ dry ton, $\$ 87.82 /$ dry ton and $\$ 70.31 /$ dry ton, respectively $(2016 \$$ ).

Additionally, 2022 projections are presented for each pathway. In 2022, the feedstock costs for IDL and AHTL are estimated to remain constant over the period, while the feedstock cost for CFP is projected to be reduced to $\$ 70.31$ dry ton due to the replacement of $75 \%$ of the clean pine with less costly forest residues and the application of stepwise air classification and leaching of the lights fraction, which improves the quality of the forest residue to match or exceed the quality of clean pine. 


\section{Table of Contents}

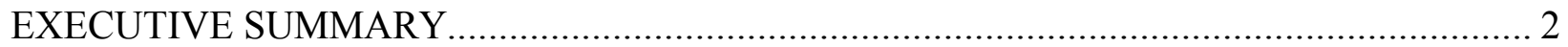

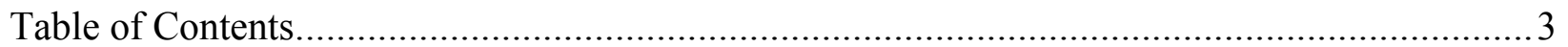

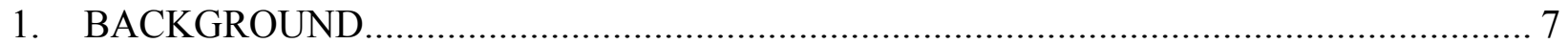

Progression of Feedstock Supply System Designs................................................. 7

2. DELIVERED FEEDSTOCK COST MODELS ....................................................... 9

2.1 Feedstock Supply Systems for Indirect Liquefaction (IDL) ...................................... 10

2.1.1 2018 SOT for Feedstock Supply to IDL.......................................................... 10

2.1.1.1 Description of Logistic System Designs.................................................... 10

2.1.1.2 Cost Summary and Energy Usage............................................................. 12

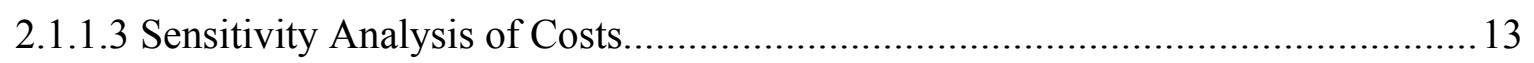

2.1.2 2022 Projection for Feedstock Supply to IDL ............................................. 15

2.1.2.1 Description of Logistic System Designs..................................................... 15

2.1.2.2 Cost Summary and Energy Usage........................................................... 16

2.1.2.3 Sensitivity Analysis of Costs......................................................................... 18

2.2 Feedstock Supply Systems for Catalytic Fast Pyrolysis (CFP)......................................20

2.2.1 2018 SOT for Feedstock Supply to CFP......................................................... 20

2.2.1.1 Description of Logistic System Designs................................................... 20

2.2.1.2 Cost Summary and Energy Usage....................................................... 22

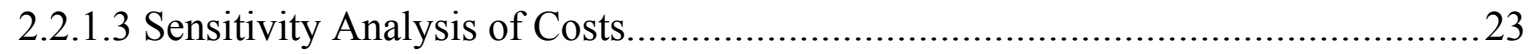

2.2.2 2022 Projection for Feedstock Supply to CFP................................................25

2.2.2.1 Description of Logistics System Designs.................................................25

2.2.2.2 Cost Summary and Energy Usage ........................................................... 27

2.2.2.3 Sensitivity Analysis of Costs.....................................................................2 28

2.3 Feedstock Supply Systems for Algal-blend Hydrothermal Liquefaction (AHTL)............ 31

2.3.1 2018 SOT for Logging Residue Supply to AHTL.......................................... 31

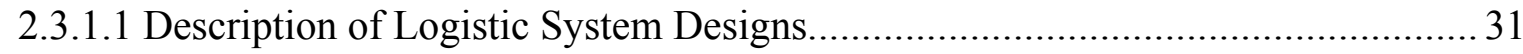

2.3.1.2 Cost Summary and Energy Usage........................................................... 33

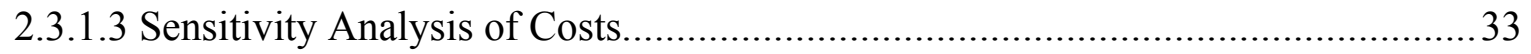

2.3.2 2022 Projection for Logging Residue Supply to AHTL ...................................... 36

2.3.2.1 Description of Logistic System Designs................................................ 36

2.3.2.2 Cost Summary and Energy Usage..................................................... 37 


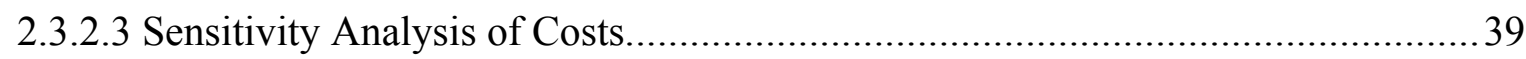

3. INDUSTRIAL RELEVANCE OF THE FEEDSTOCKS....................................................

4. QUALIFICATION OF THE FEEDSTOCKS FOR RENEWABLE IDENTIFICATION NUMBERS

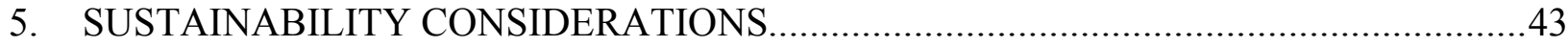

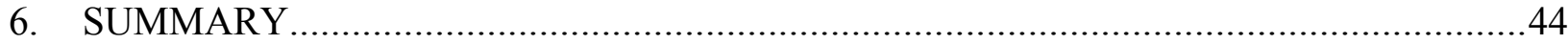



APPENDIX A - 2018 Woody State of Technology Feedstocks Logistics Design and

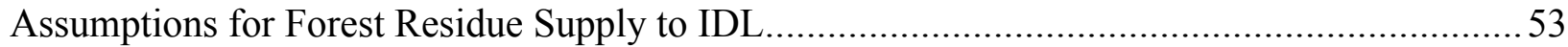

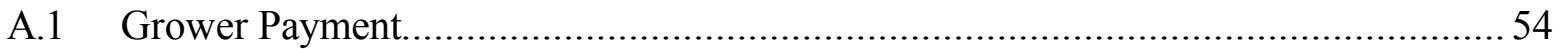

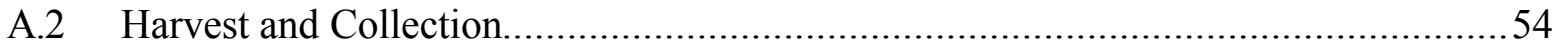

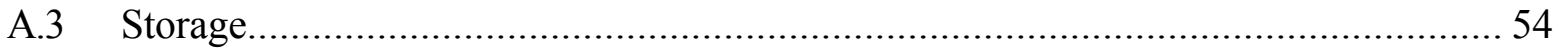

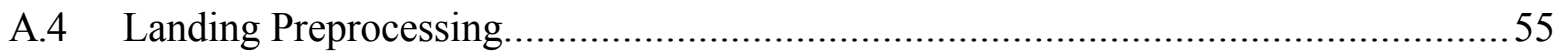

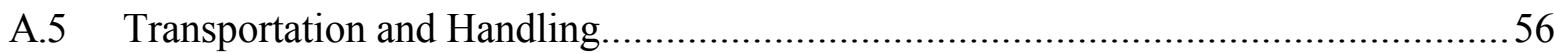

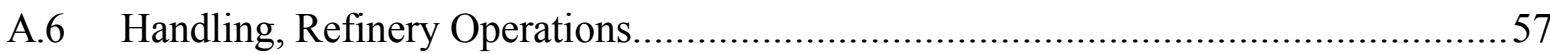

APPENDIX B - 2022 Projection for Woody Feedstock Logistics Design and Assumptions for

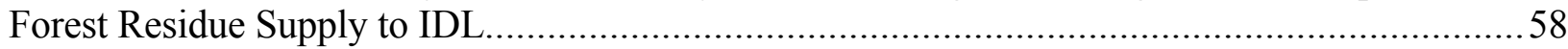

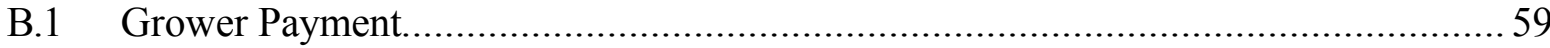

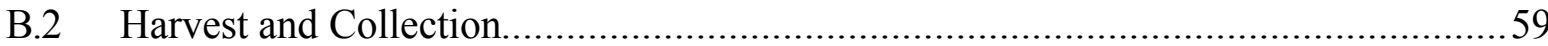

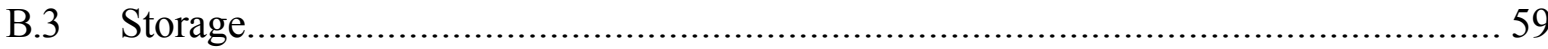

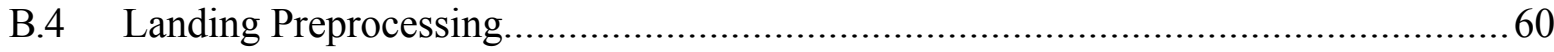

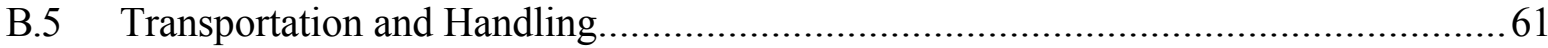

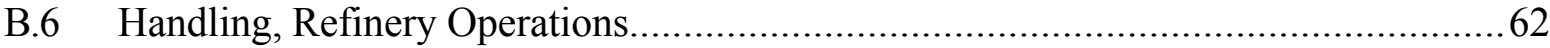

APPENDIX C - 2018 Woody State of Technology Feedstock Logistics Design and Assumptions

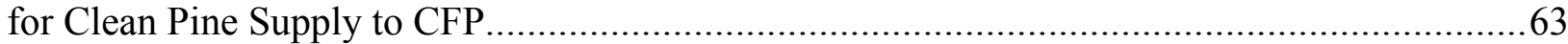

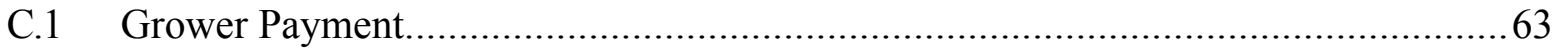

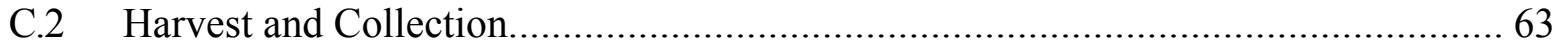

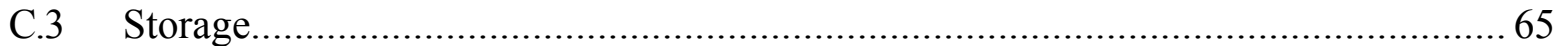

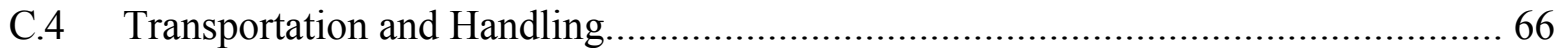



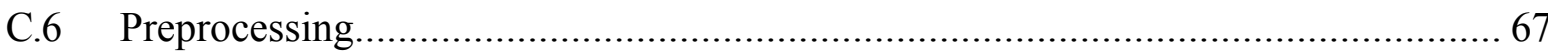

APPENDIX D - 2022 Projection for Woody Feedstock Logistics Design and Assumptions for Feedstock Supply to CFP 


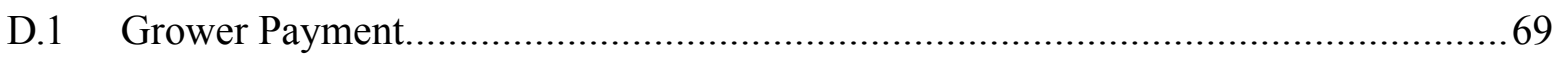

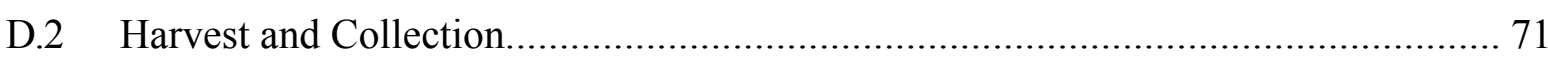

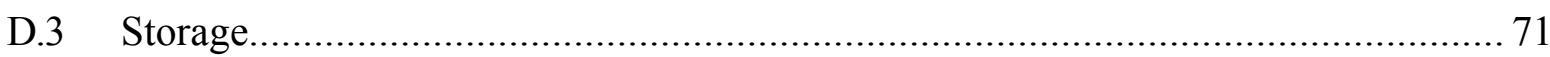

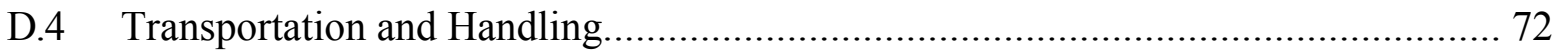

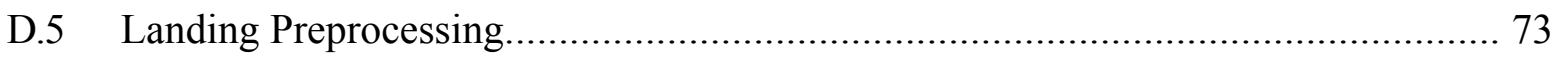

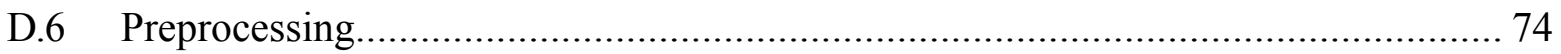

APPENDIX E - 2018 Woody State of Technology Feedstock Logistics Design and Assumptions

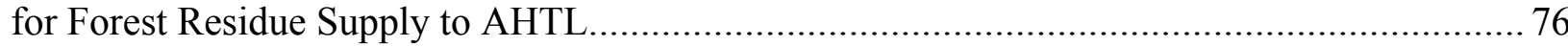

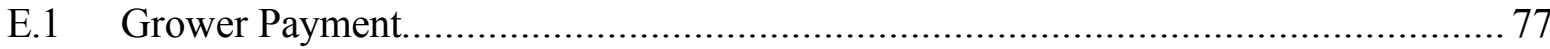

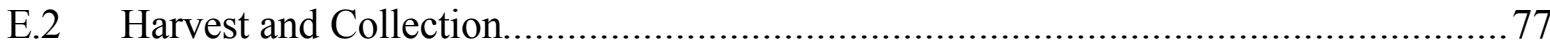

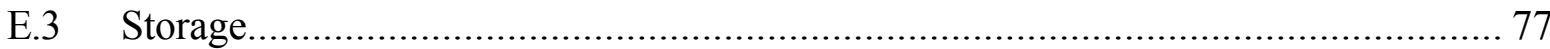

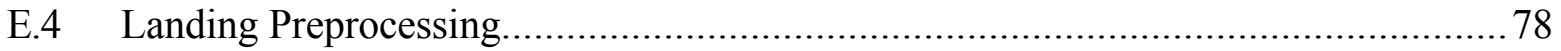

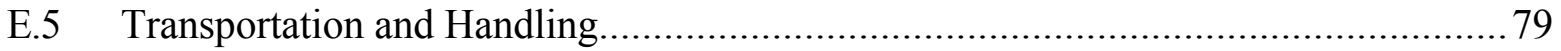

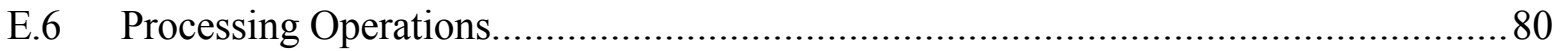

APPENDIX F - 2022 Projection for Woody Feedstock Logistics Design and Assumptions for



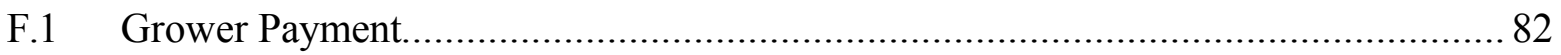

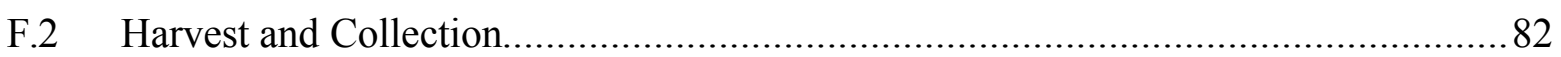

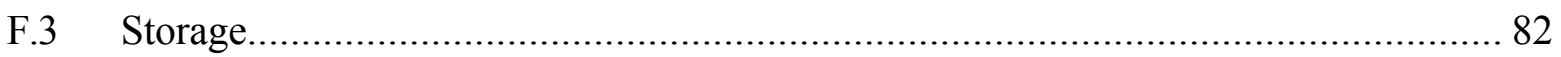

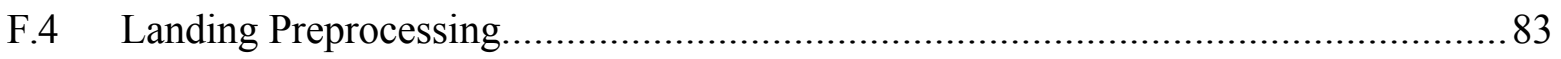

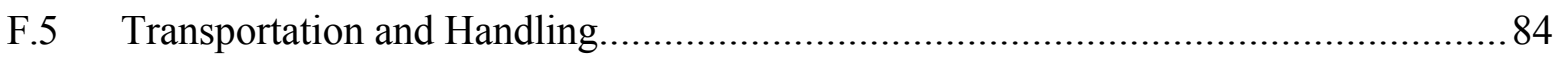

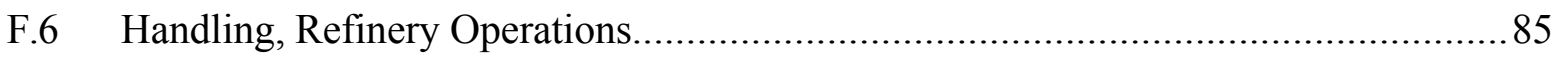

APPENDIX G - Process Flow Diagrams and Mass Balances for Supply of Forest Residues to

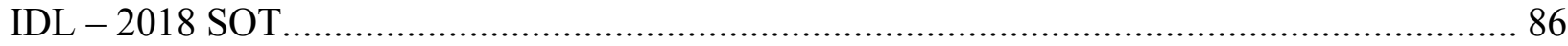

APPENDIX H - Process Flow Diagrams and Mass Balances for Supply of Forest Residues to IDL - 2022 Projection.

APPENDIX I - Process Flow Diagrams and Mass Balances for Supply of Clean Pine to CFP 2018 SOT.

APPENDIX J - Process Flow Diagrams and Mass Balances for Supply of a 25\% Clean Pine/75\% Logging Residue Blend to CFP - 2022 Projection.................................................... 107

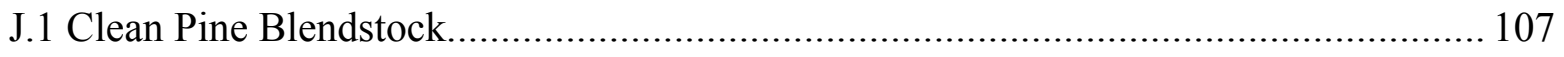

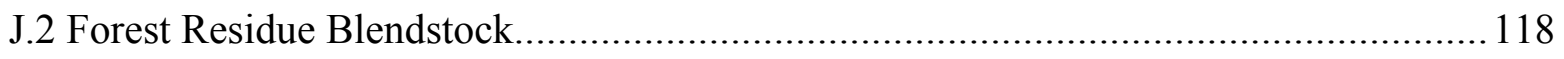
APPENDIX K - Process Flow Diagrams and Mass Balances for Supply of Logging Residues to AHTL - 2018 SOT. 


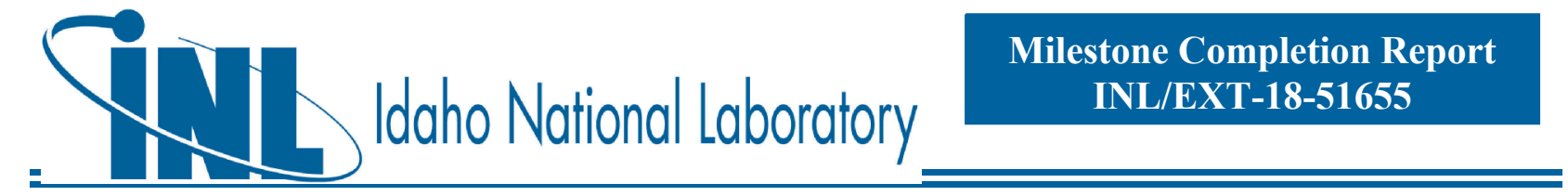

APPENDIX L - Process Flow Diagrams and Mass Balances for Supply of Logging Residues to AHTL - 2022 Projection... 131 


\section{BACKGROUND}

The U.S. Department of Energy (DOE) promotes production of advanced liquid transportation fuels from lignocellulosic biomass by funding fundamental and applied research that advances the state of technology (SOT) to transform renewable biomass into commercially viable biofuels. To gauge progress toward DOE objectives, the Bioenergy Technologies Office (BETO) sets cost and technology targets and an annual SOT report provides the status of technology relative to these goals with actual data and experimental results.

The BETO Feedstock Supply and Logistics Program developed performance targets that are directed at mobilizing large amounts of biomass. One target is to validate feedstock supply and logistics systems that can deliver feedstock at or below $\$ 85.51 /$ dry ton (2016 $\$$, including both grower payment and logistics cost through in-feed of the conversion reactor (USDOE 2017).

Feedstocks are essential to achieving BETO goals because the cost, quality, and quantity of feedstock available and accessible at any given time limits the maximum amount of biofuels that can be produced. The 2016 U.S. Billion Ton report (USDOE 2016) provides several biomass supply scenarios that show potential biomass resources that could be developed under different sets of assumptions regarding yield improvements over time. Some of these scenarios lead to a sustainable national supply of more than 1 billion tons of biomass per year by the year 2030 .

In accordance with the 2017 Multi-Year Program Plan (USDOE 2017), terrestrial feedstock supply and logistics focuses on (1) reducing the delivered cost of sustainably produced biomass, (2) preserving and improving the physical and chemical quality parameters of harvested biomass to meet the individual needs of biorefineries and other biomass users, and (3) expanding the quantity of feedstock materials accessible to the bioenergy industry. This is done by identifying, developing, demonstrating, and verifying efficient and economical integrated systems for harvest and collection, storage, handling, transport, and preprocessing raw biomass from a variety of crops to reliably deliver the required supplies of high-quality, affordable feedstocks to biorefineries as the industry expands. The elements of cost, quality, and quantity are key considerations when developing advanced feedstock supply concepts and systems (USDOE 2015).

\section{Progression of Feedstock Supply System Designs}

Feedstock supply systems are highly complex organizations of operations required to move and transform biomass from a raw form at the point of production into a formatted, onspec feedstock at the throat of the reactor. Feedstock logistics can be broken down into unit operations, including harvest and collection; storage; transportation; preprocessing; and queuing and handling. Designing economic and environmentally sustainable feedstock supply systems, while providing necessary resource quantities at the appropriate quality, is critical to growth of the bioenergy industry. 
Research on feedstock supply systems aims to reduce delivered cost, improve or preserve feedstock quality, and expands access to biomass resources. Through 2012, BETO-funded research on feedstock supply systems focused on improving conventional feedstock supply systems. Conventional feedstock supply system designs rely on existing technology and systems to supply feedstock to biorefineries (Figure 1). Conventional designs tend to be vertically integrated, with a specific conversion process or biorefinery; they also place all burden of adapting to feedstock variability on the biorefinery. Within the constraints of local supply, equipment availability, and permitting requirements, biorefineries strive to optimize efficiencies and capacities. However, this approach makes the system vulnerable to feedstock variability.

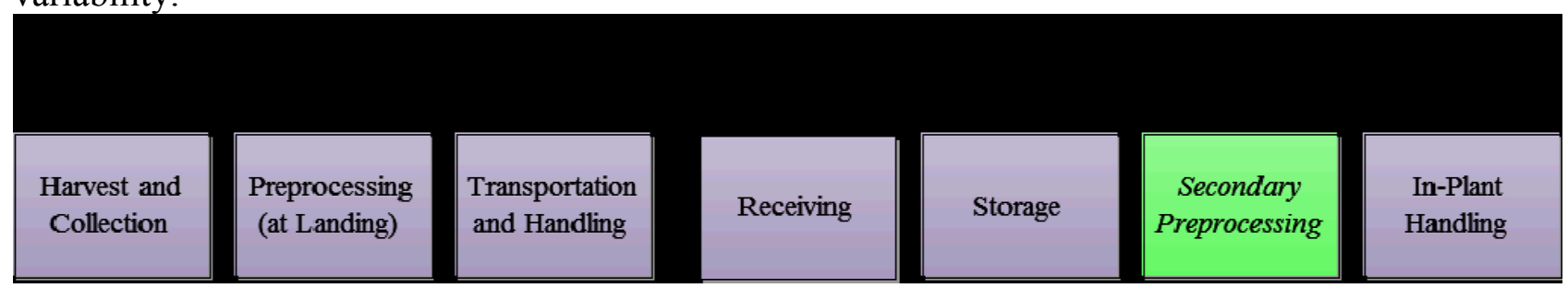

Figure 1. Conventional feedstock supply system designs rely on existing technologies and biomass to supply biorefineries, but they require biorefineries to adapt to the variability of feedstock.

Conventional designs are currently the backbone of the emerging biofuels industry. However, conventional feedstock supply systems have limitations that restrict widespread implementation on a national scale (Hess et al. 2009, Searcy and Hess 2010). The original thought was that the conventional supply system designs could be successful in geographical areas that have a concentrated supply of easily accessible and low-cost biomass resources (such as corn stover in the Midwestern United States and pine in the southeastern United States). Moving outside these select regions, the feedstock supply system must be adapted to accommodate a changing cost, quality, and conversion facility's size constraints.

Conventional systems can only address feedstock quality indirectly through passive controls such as resource selection or best management practices. An example of this is the high-capacity grapple used in the DOE-funded Auburn High Tonnage Biomass Logistics Demonstration Project (Sokhansanj et al. 2014), which prevented woody material from being dragged along the ground during skidding, preventing ash entrainment. When positioned in a highly productive single resource area, biorefineries can be selective in contracting only those feedstocks that meet their specifications. However, biomass quality (e.g., ash and moisture content) is highly variable both spatially and temporally (Kenney et al. 2013) and, in any given year, passive controls might not provide enough quality control for feedstock to meet the desired in-feed characteristics. Therefore, biorefineries that rely on conventional designs are constrained to local resources and are limited in the expansion of the collection radius, which limits plant size (Graham et al. 2013). 
Several analyses have shown that as the biofuels industry expands past the highly productive regions, conventional supply systems will fail to meet supply requirements (Argo et al. 2013, Bonner et al. 2014, Hess et al. 2009, Lamers et al. 2015, Muth et al. 2014). To meet the demands of future industry, the feedstock supply system will be required to expand beyond conventional systems in certain areas, to what has been termed “advanced" feedstock supply systems (AFSS) (Hess et al. 2009, Searcy and Hess 2010, Jacobson et al. 2014). Advanced systems incorporate innovative methods of material handling, processing and supply chain configuration.

The 2018 Woody SOT presents current supply chain designs for three conversion pathways that utilize woody biomass as a feedstock: Indirect Liquefaction (IDL), Catalytic Fast Pyrolysis (CFP) and Algal-blend High Temperature Liquefaction (AHTL). IDL is a gasification technology and has the least complicated feedstock supply system, primarily because the feedstock quality requirements for gasification technologies are less stringent than those of pyrolysis technologies, however, the conversion operations are more expensive. For gasification, the particle size can be larger and the quantity of ash can be higher, both aspects that reduce the amount of preprocessing needed. However, the higher cost of the conversion operation requires feedstocks with delivered costs approximately $25 \%-30 \%$ lower than the pyrolysis feedstock. To meet the new feedstock requirements the design was changed, reverting from an advanced system that preprocessed the biomass to a conventional system that delivered unpreprocessed chips from forest residue directly to the biorefinery. In addition, since the materials were delivered directly to the biorefinery, process heat was available to perform the drying.

CFP requires a finely-ground, low ash, high quality feedstock. The 2018 SOT utilizes "clean pine" as the model feedstock. The choice to utilize a single feedstock requires that the facility locate in an area with large inventories of available Renewable Identification Number (RIN)-qualified pine. For the "clean pine" case, the location of the biorefinery is in the Piedmont Region on the South Carolina/Georgia border. The use of a single feedstock results in increased transport distances.

AHTL uses logging residue, similar to IDL, with the differences being a much lower total quantity of material, but also that the final material must be ground to a smaller size. Additionally, the location of the resource has been specified as the Gulf coast region, to meet the requirements for algal growth.

\section{DELIVERED FEEDSTOCK COST MODELS}

The Biomass Logistics Model (BLM) (Cafferty et al. 2013a) was used to model feedstock supply system cost and energy consumption for the 2018 Woody SOT. The BLM incorporates information from a collection of databases that provide (1) engineering performance data for hundreds of equipment systems, (2) spatially explicit labor cost datasets, and (3) local tax and regulation data. The BLM's analytic engine is built in the systems dynamics software package Powersim $^{\mathrm{TM}}$. The BLM is designed to work with thermochemical and biochemical-based 


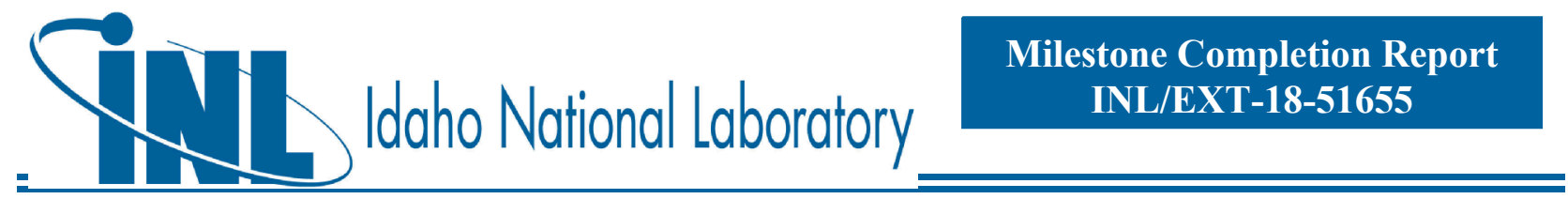

biofuel conversion platforms and to accommodate a range of lignocellulosic biomass types (e.g., residues, short-rotation woody and herbaceous energy crops, woody residues, and algae). BLM simulates the flow of biomass through the entire supply chain, while tracking changes in feedstock characteristics (i.e., moisture content, dry matter, ash content, and dry bulk density) and calculating cost and energy consumption (Cafferty et al. 2013a). These estimates are then input into the greenhouse gas, regulated emissions, and energy use in transportation model to perform a cursory farm gate-to-plant gate lifecycle assessment on greenhouse gas (GHG) emissions.

\subsection{Feedstock Supply Systems for Indirect Liquefaction (IDL)}

The 2018 and 2022 IDL conversion pathway assumes annual $\mathrm{n}^{\text {th }}$ plant delivery of 725,000 dry tons of woody feedstock, with total ash $\leq 3 \mathrm{wt} \%$, moisture content $\leq 10 \%$ (wet basis), and particle size of 2" chips (Table 1). The IDL conversion pathway has a delivered feedstock cost target of $\$ 63.76 /$ dry ton $(2016 \$)$ in 2022 , including dockage.

Table 1. Delivered feedstock composition assumptions for indirect liquefaction.

\begin{tabular}{|lc|} 
Carbon & $\begin{array}{c}\text { Composition } \\
\text { (dry wt. \%) }\end{array}$ \\
Hydrogen & 49.81 \\
Nitrogen & 5.91 \\
Sulfur & 0.17 \\
Oxygen & 0.09 \\
\hline Ash & 41.02 \\
\hline Heating Value (Btu/lb) & 3.00 \\
\hline Moisture (Bulk Wt. \%) & $8,449 \mathrm{HHV}$ \\
Particle Size (inches) & $7,856 \mathrm{LHV}$ \\
\hline
\end{tabular}

\subsubsection{SOT for Feedstock Supply to IDL}

\subsubsection{Description of Logistic System Designs}

The 2018 SOT for feedstock supply to IDL is reported in 2016 dollars (2016\$) and includes both grower payment and logistics costs to reflect a total delivered feedstock supply cost. This report outlines the 2018 woody SOT design that was capable of achieving a modeled delivered feedstock cost of $\$ 63.76 /$ dry ton. The cost of logging residue delivered for IDL has increased by $\$ 3.26 /$ dry ton from the 2017 Woody SOT due to projected reductions in material availability. Logistics costs include harvest, collection, storage, 
transportation, and preprocessing costs from the point of harvest to the conversion reactor throat in-feed. Grower payment represents the stumpage payment and includes the cost of production, compensation for soil nutrient removal, and grower profit. The IDL process has less stringent quality and particle size requirements than that of pyrolysis, resulting in a simple preprocessing design along with the utilization of considerably cheaper forest residues.

The logistics system for the 2018 SOT, delivering 725,000 dry tons of forest residue, is the same as that described in the 2017 Woody SOT report (Hartley et al., 2017). The IDL system places fewer restrictions on the feedstock specifications in terms of particle size and ash content, which removed the necessity of much of the preprocessing required as compared to prior analyses (which targeted fast pyrolysis.

Grower Payment

Grower payment represents the stumpage price paid to the landowner to secure permission to harvest the material. The grower payment was calculated using the size class stumpage values reported in the 2016 Billion Ton Report (BT16; USDOE, 2016). BT16 provides values of $\$ 32.40$ /dry ton, $\$ 16.20$ /dry ton and $\$ 8.10$ /dry ton, for both planted and natural softwood stands, of size classes 1, 2 and 3, respectively, in the Southern Region. The calculation of forest residue grower payment utilizes the residue ratios from the USDA Forest Service Forest Inventory and Analysis Database (USDA Forest Service, 2017), to determine the proportion of the value of the whole tree stumpage that remains after the harvest as residue. Based on the assumed harvest region, the size class distribution of delivered material and residue ratio, the weighted average grower payment of Forest residue is $\$ 3.75 /$ dry ton.

\section{Fieldside Operations}

2018 fieldside operations in this design are the same as those presented in the 2017 SOT for gasification (Hartley et al., 2017). As before, it is assumed that the forest residue is brought to the landing as part of the primary harvest operation and as such does not incur harvest or collection cost. Instead, the supply chain starts with size reduction of material that has been dried to $30 \%$ moisture content in the field. Size reduction is performed with a mobile chipper, and the operational characteristics of the equipment are based on descriptions resulting from the High Tonnage project completed by Auburn University (Sokhansanj et al., 2014). The chips are blown directly into a truck for transport, eliminating the need for additional loading equipment.

\section{Biorefinery Operations}

The forest residue chips are delivered to the refinery by truck, where they are offloaded using a truck tipper with a hopper. From the hopper the chips are conveyed to storage piles until they are dried using a rotary drier. After drying the chips to $10 \%$ moisture content, the chips are held in covered storage until feeding to the conversion process.

\section{Processing Location Construction Cost}

Construction and infrastructure costs were estimated as follows. Hu et al. (2017) utilized installation factors ranging from 1.43-1.7 to estimate the capital layout for construction and 
infrastructure for individual preprocessing equipment similar to the equipment in this design. For our calculations, we used the higher value of 1.7 for all preprocessing equipment to provide the more conservative estimate. Hence, the total capital layout for construction and infrastructure was estimated using an installation factor of 1.7 together with the installed capital cost of all preprocessing, handling and storage equipment; the estimate includes site preparation, construction, engineering and contingency (Hu et al. 2017). Land cost was calculated assuming 160 acres per depot at a cost of $\$ 500 /$ acre, and was added to the capital cost to determine the loan amount. The total cost was amortized over 30 years, assuming a $20 \%$ down payment and an $8 \%$ interest rate, and divided by the number of delivered tons to give the per ton cost of depot construction and infrastructure, which totaled $\$ 2.73 /$ dry ton.

\subsubsection{Cost Summary and Energy Usage}

Results of the supply chain analysis are summarized in Table 2, which provides the detailed cost breakdown.

Table 2. Summary of modeled cost estimates for the woody feedstock supply systems providing feedstocks to IDL.

\begin{tabular}{lc}
\multicolumn{2}{c}{ Cost Summary (\$/Dry Ton) } \\
& IDL \\
& $\mathbf{2 0 1 8}$ SOT \\
\hline Grower Payment & $\$ 3.75$ \\
Harvest \& Collection & $\$ 0.00$ \\
Fieldside Preprocessing & $\$ 11.08$ \\
Transportation & $\$ 20.22$ \\
Preprocessing & $\$ 19.38$ \\
Storage & $\$ 0.67$ \\
Handling & $\$ 2.70$ \\
Preprocessing Construction & $\$ 2.73$ \\
Quality Dockage & $\$ 3.22$ \\
Grand Total & $\$ \mathbf{6 3 . 7 6}$
\end{tabular}

Table 3 presents the greenhouse gas emissions (GHG) for the 2018 SOT feedstock supply to the IDL pathway. The greenhouse gas emissions analysis was completed by Argonne National Laboratory (ANL), using energy consumption and transportation distance data from the BLM. ANL employed the Greenhouse Gases, Regulated Emissions, and Energy use in Transportation model (GREET ${ }^{\circledR}$ ) (Argonne National Laboratory, 2017) to conduct detailed life-cycle analysis of farm gate-to-biorefinery gate GHG emissions of the woody biomass scenarios presented in this report. 


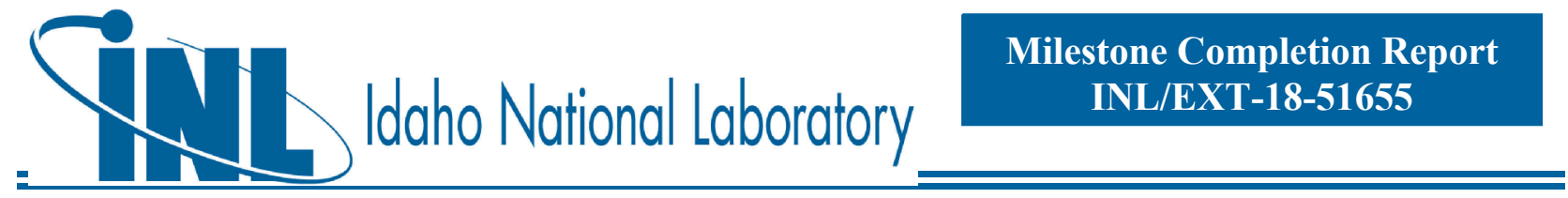

Table 3. Summary of greenhouse gas emissions (GHG) for 2018 SOT feedstock supply to the IDL pathway.

\begin{tabular}{lc}
\multicolumn{2}{c}{ Greenhouse Gas Emissions $\left(\mathrm{kg} \mathrm{CO}_{2} \mathrm{e} / \mathrm{dry}\right.$ ton) } \\
IDL \\
Harvest \& Collection & $\mathbf{7 0 1 8} \mathbf{c o T}$ \\
Fieldside Preprocessing & 0.000 \\
Transportation from Fieldside & 24.876 \\
Preprocessing & 12.755 \\
Storage & 25.920 \\
Handling & 0.858 \\
Grand Total & 1.969 \\
\hline
\end{tabular}

\subsubsection{Sensitivity Analysis of Costs}

Sensitivity analysis was performed to determine the impact that alternate values for key operational parameters would have on the delivered cost presented as the 2018 SOT Design. The feedstock utilized in the final design required only minimal processing in order to be suitable for use in conversion. This resulted in a set of relatively few model parameters that were considered to potentially have impact on the final delivered price. Model parameters were chosen that could be variable or could cause variability in the preprocessing operations and ultimately cost. The final set of sensitivity parameters consisted of the final ash content of the material, the throughput of the chipper at the roadside, the energy consumption of the chipper at the roadside, the dryer throughput at the biorefinery, and the energy consumption of the dryer at the biorefinery. Each of the equipment parameters were varied based on variation seen in the processes, based on literature, from the values that were used in the final model run (Cao et al., 2007; Spinelli et al., 2012; Thompson et al. 2013). The values used are presented in Table 4.

Table 4. Sensitivity parameters for the 2018 SOT feedstock supply to the IDL pathway.

\begin{tabular}{lccc} 
& Min & Mean & Max \\
Dryer Capacity & $1.48 \mathrm{odt} / \mathrm{hr}$ & $1.5 \mathrm{odt} / \mathrm{hr}$ & $1.53 \mathrm{odt} / \mathrm{hr}$ \\
Dryer Energy & $325.5 \mathrm{kWh} / \mathrm{t}$ & $350 \mathrm{kWh} / \mathrm{t}$ & $374.5 \mathrm{kWh} / \mathrm{t}$ \\
Chpper Capacity & $76.37 \mathrm{odt} / \mathrm{hr}$ & $79.80 \mathrm{odt} / \mathrm{hr}$ & $83.00 \mathrm{odt} / \mathrm{hr}$ \\
Chipper Energy & $13.2 \mathrm{kWh} / \mathrm{t}$ & $18.5 \mathrm{kWh} / \mathrm{t}$ & $26.5 \mathrm{kWh} / \mathrm{t}$ \\
\hline
\end{tabular}




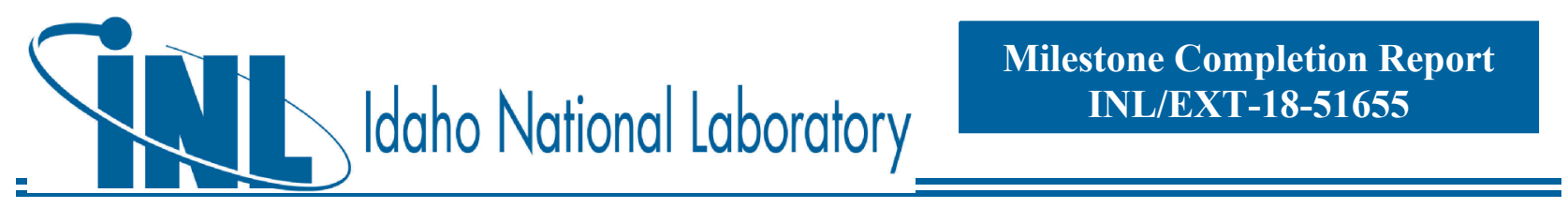

Figure 2 presents the results of the sensitivity analysis. The delivered cost is most sensitive to chipper energy consumption, followed by the throughput of the chipper equipment. The impact of energy consumption on the chipper is because of the relative uncertainty that can be seen when processing material. The impact of throughput has to do with the distributing the cost of the piece of equipment over the amount of material that is processed. When the throughput is decreased the cost increases, while when throughput increases the cost decreases.



Figure 2. Tornado chart showing sensitivity of cost to operational parameters used to model the 2018 SOT Case for IDL 


\subsubsection{Projection for Feedstock Supply to IDL}

\subsubsection{Description of Logistic System Designs}

The logistics system for the 2022 Projection delivers only forest residue is the same that was described in the 2017 SOT report (Hartley et al. 2017) and is used in the 2018 SOT.

\section{Grower Payment}

Grower payment represents the stumpage price paid to the landowner to secure permission to harvest the material. The grower payment was calculated using the size class stumpage values reported in the 2016 Billion Ton Report (BT16; USDOE, 2016). BT16 provides values of $\$ 32.40$ /dry ton, $\$ 16.20$ /dry ton and $\$ 8.10$ /dry ton, for both planted and natural softwood stands, of size classes 1, 2 and 3, respectively, in the Southern Region. The calculation of forest residue grower payment utilizes the residue ratios from the USDA Forest Service Forest Inventory and Analysis Database (USDA Forest Service, 2017), to determine the proportion of the value of the whole tree stumpage that remains after the harvest as residue. Based on the assumed harvest region, the size class distribution of delivered material and residue ratio, the weighted average grower payment of Forest residue is $\$ 3.75 /$ dry ton.

\section{Fieldside Operations}

2022 fieldside operations in this design are the same as those presented in the 2017 SOT for gasification (Hartley et al., 2017). As before, it is assumed that the forest residue is brought to the landing as part of the primary harvest operation and as such does not incur harvest or collection cost. Instead, the supply chain starts with size reduction of material that has been dried to $30 \%$ moisture content in the field. Size reduction is performed with a mobile chipper, and the operational characteristics of the equipment are based on descriptions resulting from the High Tonnage project completed by Auburn University (Sokhansanj et al. 2014). The chips are blown directly into a truck for transport, eliminating the need for additional loading equipment.

\section{Biorefinery Operations}

The forest residue chips are delivered to the refinery by truck, where they are offloaded using a truck tipper with a hopper. From the hopper the chips are conveyed to storage piles until they are dried using a rotary drier. After drying the chips to $10 \%$ moisture content, the chips are held in covered storage until feeding to the conversion process.

\section{Processing Location Construction Cost}

Construction and infrastructure costs were estimated as follows. Hu et al. (2017) utilized installation factors ranging from 1.43-1.7 to estimate the capital layout for construction and infrastructure for individual preprocessing equipment similar to the equipment in this design. For our calculations, we used the higher value of 1.7 for all preprocessing equipment to provide the more conservative estimate. Hence, the total capital layout for construction and infrastructure was estimated using an installation factor of 1.7 together with the installed capital cost of all preprocessing, handling and storage equipment; the estimate includes site preparation, construction, engineering and contingency (Hu et al. 2017). Land cost was calculated assuming 
160 acres per depot at a cost of $\$ 500 /$ acre, and was added to the capital cost to determine the loan amount. The total cost was amortized over 30 years, assuming a $20 \%$ down payment and an $8 \%$ interest rate, and divided by the number of delivered tons to give the per ton cost of depot construction and infrastructure, which totaled \$2.73/dry ton.

\subsubsection{Cost Summary and Energy Usage}

Results of the analyses are summarized in Table 5, Figure 3 and Table 6 below. Table 5 provides the detailed cost components for the 2017 and 2018 SOTs, as well as the projection for 2022, with a waterfall chart of the information presented in Figure 3. It can be noticed that the cost of the 2022 Projection increases over the 2017 and 2018 SOT's. The reason for this is that the projected availability of logging residue is projected to decrease into the future. The decrease in material, necessitates a greater travel distance and a greater cost of transportation. Finally, Table 6 presents the greenhouse gas emissions (GHG) for the 2017 and 2018 SOTs and the projected 2022 case.

Table 5. Summary of modeled cost estimates for the woody feedstock supply systems providing feedstocks to IDL for the 2017 SOT, 2018 SOT and 2022 Projection.

\begin{tabular}{|c|c|c|c|}
\hline \multicolumn{4}{|c|}{ Cost Summary (\$/Dry Ton) (2016\$) } \\
\hline & IDL & IDL & IDL \\
\hline & 2017 & 2018 SOT & MOMT Duninntinn \\
\hline Grower Payment & $\$ 3.75$ & $\$ 3.75$ & $\$ 3.75$ \\
\hline Harvest \& Collection & $\$ 0.00$ & $\$ 0.00$ & $\$ 0.00$ \\
\hline Fieldside Preprocessing & $\$ 11.08$ & $\$ 11.08$ & $\$ 11.08$ \\
\hline Transportation & $\$ 16.97$ & $\$ 20.22$ & $\$ 20.22$ \\
\hline Preprocessing & $\$ 19.38$ & $\$ 19.38$ & $\$ 19.38$ \\
\hline Storage & $\$ 0.67$ & $\$ 0.67$ & $\$ 0.67$ \\
\hline Handling & $\$ 2.70$ & $\$ 2.70$ & $\$ 2.70$ \\
\hline Preprocessing Construction & $\$ 2.73$ & $\$ 2.73$ & $\$ 2.73$ \\
\hline Quality Dockage & $\$ 3.22$ & $\$ 3.22$ & $\$ 3.22$ \\
\hline Grand Total & $\$ 60.50$ & $\$ 63.76$ & $\$ 63.76$ \\
\hline
\end{tabular}



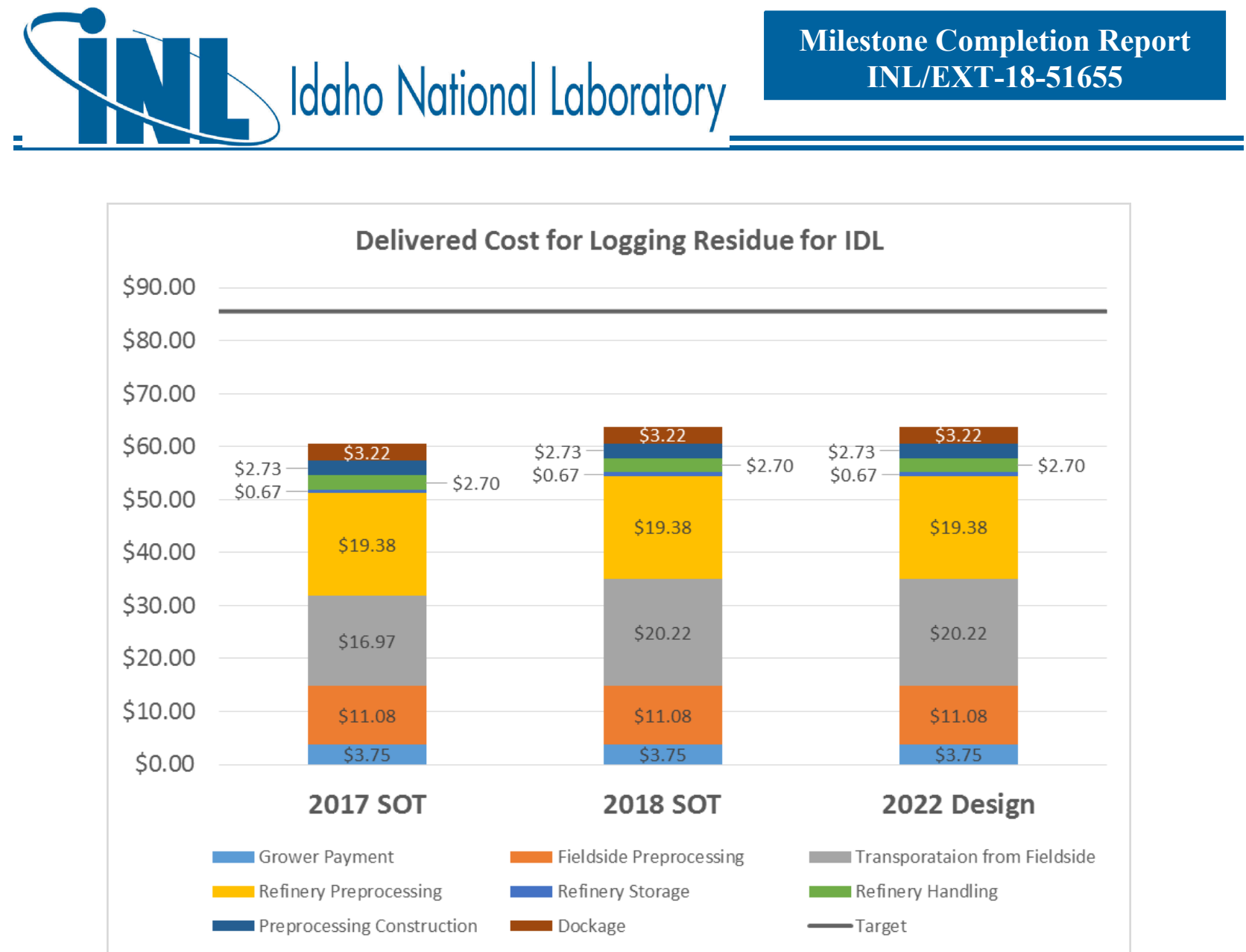

Figure 3. Waterfall chart of delivered chipped logging residue to the IDL process in years 2017, 2018 and projected for 2022

Table 6. Summary of Greenhouse gas emissions for the woody feedstock supply systems for IDL for the 2017 SOT, 2018 SOT and 2022 Projection.

\begin{tabular}{|c|c|c|c|}
\hline \multicolumn{4}{|c|}{ Greenhouse Gas Emissions (kg $\mathrm{CO}_{2} \mathrm{e} / \mathrm{dry}$ ton) } \\
\hline & $\begin{array}{c}\text { IDL } \\
2017 \text { SOT }\end{array}$ & $\begin{array}{c}\text { IDL } \\
2018 \text { SOT }\end{array}$ & IDL \\
\hline Harvest \& Collection & 0.000 & 0.000 & 0.000 \\
\hline Fieldside Preprocessing & 24.876 & 24.876 & 24.876 \\
\hline Transportation & 12.755 & 12.755 & 15.875 \\
\hline Preprocessing & 25.920 & 25.920 & 25.920 \\
\hline Storage & 0.858 & 0.858 & 0.858 \\
\hline Handling & 1.969 & 1.969 & 1.969 \\
\hline Grand Total & 66.393 & 66.393 & 69.513 \\
\hline
\end{tabular}




\subsubsection{Sensitivity Analysis of Costs}

Sensitivity analysis was performed to determine the impact that alternate values for key operational parameters would have on the delivered cost presented as the 2022 Projection. The feedstock utilized in the final design required only minimal processing in order to be suitable for use in conversion. This resulted in a set of relatively few model parameters that were considered to potentially have impact on the final delivered price. Model parameters were chosen that could be variable or could cause variability in the preprocessing operations and ultimately cost. The final set of sensitivity parameters consisted of the final ash content of the material, the throughput of the chipper at the roadside, the energy consumption of the chipper at the roadside, the dryer throughput at the biorefinery, and the energy consumption of the dryer at the biorefinery. Each of the equipment parameters were varied based on variation seen in the processes, based on literature, from the values that were used in the final model run (Cao et al., 2007; Spinelli et al., 2012; Thompson et al. 2013). The values used are presented in Table 7.

Table 7. Sensitivity parameters for the 2022 Projection feedstock supply to the IDL pathway.

\begin{tabular}{lccc} 
& Min & Mean & Max \\
Dryer Capacity & $1.48 \mathrm{odt} / \mathrm{hr}$ & $1.5 \mathrm{odt} / \mathrm{hr}$ & $1.53 \mathrm{odt} / \mathrm{hr}$ \\
Dryer Energy & $325.5 \mathrm{kWh} / \mathrm{t}$ & $350 \mathrm{kWh} / \mathrm{t}$ & $374.5 \mathrm{kWh} / \mathrm{t}$ \\
Chpper Capacity & $76.37 \mathrm{odt} / \mathrm{hr}$ & $79.80 \mathrm{odt} / \mathrm{hr}$ & $83.00 \mathrm{odt} / \mathrm{hr}$ \\
Chipper Energy & $13.2 \mathrm{kWh} / \mathrm{t}$ & $18.5 \mathrm{kWh} / \mathrm{t}$ & $26.5 \mathrm{kWh} / \mathrm{t}$ \\
\hline
\end{tabular}

Figure 4 presents the results of the sensitivity analysis. The delivered cost is most sensitive to chipper energy consumption, followed by the throughput of the chipper equipment. The impact of energy consumption on the chipper is because of the relative uncertainty that can be seen



Figure 4. Tornado chart showing sensitivity of cost to operational parameters used to model the 2022 Projection for IDL. 


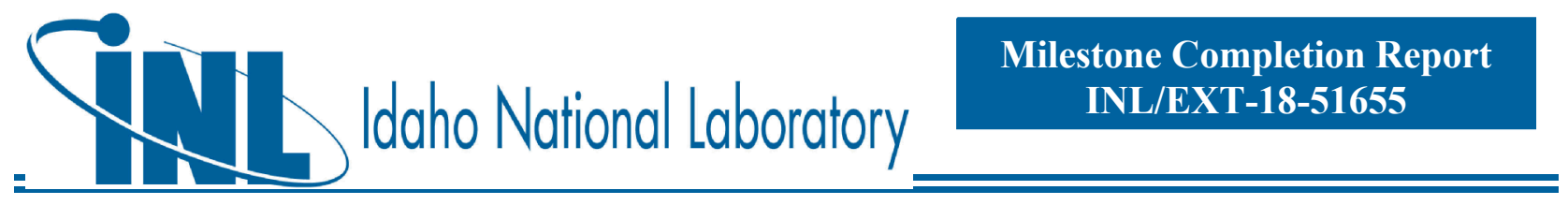

when processing material. The impact of throughput has to do with the distributing the cost of the piece of equipment over the amount of material that is processed. When the throughput is decreased the cost increases, while when throughput increases the cost decreases. 


\subsection{Feedstock Supply Systems for Catalytic Fast Pyrolysis (CFP)}

The 2018 and 2022 CFP conversion pathway assumes annual $n^{\text {th }}$ plant delivery of 725,000 dry tons of woody feedstock, with total ash $\leq 0.9 \mathrm{wt} \%$, moisture content $\leq 10 \%$ (wet basis), and particle size of $1 / 4^{\prime \prime}-$ minus (Table 8). The CFP pathway has a delivered feedstock cost target of $\$ 70.31 /$ dry ton $(2016 \$)$ in 2022, including dockage.

Table 8. Delivered feedstock composition assumptions for CFP.

\begin{tabular}{|lc|}
\hline Carbon & Composition \\
\hline Hydrogen & 50.94 \\
Nitrogen & 6.04 \\
Sulfur & 0.17 \\
Oxygen & 0.03 \\
\hline Ash & 41.90 \\
\hline Heating Value (Btu/lb) & 0.90 to 1.0 \\
\hline Moisture (Bulk Wt. \%) & $8,601 \mathrm{HHV}$ \\
\hline Particle Size (inches) & $7,996 \mathrm{LHV}$ \\
\hline
\end{tabular}

\subsubsection{SOT for Feedstock Supply to CFP}

\subsubsection{Description of Logistic System Designs}

The logistics system for the 2018 SOT for feedstocks for Catalytic Fast Pyrolysis delivers 725,000 dry tons of clean pine, using similar systems as had been previously described in the SOT's from 2013 to 2017 (Cafferty, 2013, Hartley and Cafferty, 2014, Hartley et al., 2015, Hartley et al., 2016 and Hartley et al., 2017). The system harvests plantation grown pine and forest thinning material using a mechanized harvest system. Logs are sent to the processing facility where they are size reduced and densified before feeding into the conversion process. Grower Payment

Grower payment represents the stumpage price paid to the landowner to secure permission to harvest the material. The grower payment was calculated using the size class stumpage values reported in the 2016 Billion Ton Report (BT16; USDOE, 2016). BT16 provides values of $\$ 32 /$ dry ton, $\$ 16 /$ dry ton and $\$ 8 /$ dry ton, for both planted and natural softwood stands, of size classes 1, 2 and 3, respectively in the Southern Region. Based on the assumed harvest region, the 
size class distribution of delivered material was $83 \%$ from size class 3 and $17 \%$ from size class 2 ; the resulting weighted average grower payment for clean pine is then calculated as $\$ 9.48 /$ dry ton.

\section{$\underline{\text { Fieldside Operations }}$}

Fieldside operations in this design are similar to those described in the clean pine/pyrolysis section of the 2017 Woody Feedstock SOT report (Hartley et al., 2017). Felling is completed using a feller-buncher, and skidding with a grapple skidder. Operational characteristics of both pieces of equipment are based on descriptions resulting from the High Tonnage project completed by Auburn University (Sokhansanj et al., 2014). As for the Blend/Pyrolysis analysis, the primary departure from the harvest and collection system presented in the prior SOTs is that the fieldside preprocessing operations have been moved to the depots to take advantage of the high density of logs during initial transportation. In previous SOTs, clean pine comprised only a small proportion of the blend, and so in order to reduce capital cost at the single co-located depot, the logs were previously chipped at the landing and transported to the depot. This allowed cost savings by aligning with the chip format of the other blendstocks (chipped forest residues and harvested short rotation hybrid poplar). For the new $100 \%$ clean pine case, however, there is no longer a need to align with the chip format, and it becomes more efficient to process the material at the depots. Because of this change it is no longer necessary to delimb and debark at fieldside. Delimbing is accomplished just prior to stacking for storage using a lower cost delimbing gate. Debarking is accomplished using a rotary head debarker at the depot, allowing removal of the costly and energy inefficient chain flail at the fieldside landing. It is worth noting that use of the delimbing gate resulted in reduced productivity of the grapple skidder, since the stems are manually forced through a metal grid by the skidder to remove the branches.

\section{Preprocessing Operations}

The logs are unloaded from the trucks using a high-lift loader, and placed into storage piles. To initiate preprocessing, logs are delivered by loader to a rotary head debarker, and the debarked logs are conveyed to a $25 \mathrm{ton} / \mathrm{hr}$ disk chipper to produce an approximate 1-in nominal chip. The chips are conveyed to a rotary shear for the final size reduction, which provides better control of particle size distribution, and is impacted little by the moisture content of the biomass. The material exiting the rotary shear is conveyed to a surge bin, which feeds the pellet mill. The pellets are then conveyed to a cross flow grain dryer and dried to $10 \%$ moisture (wet basis). The dried pellets are stored in a covered metal bin. The pellets are conveyed to a crumbler for feeding to the conversion process.

\section{Processing Location Construction Cost}

Preprocessing construction and infrastructure costs were estimated using the same method as in the 2017 SOT (Hartley et al, 2017). Hu et al. (2017) utilized construction and installation factors ranging from 1.43-1.7 to estimate the capital layout for construction and infrastructure for individual preprocessing equipment similar to the equipment in this design. For our calculations, we used the higher value of 1.7 for all preprocessing equipment to provide the more conservative estimate. Hence, the total capital layout for construction and infrastructure was estimated using 
an installation factor of 1.7 together with the installed capital cost of all preprocessing, handling and storage equipment; the estimate includes site preparation, construction, engineering and contingency (Hu et al. 2017). Land cost was calculated assuming 160 acres per depot at a cost of $\$ 500 /$ acre, and was added to the capital cost to determine the loan amount. The total cost was amortized over 30 years, assuming a $20 \%$ down payment and an $8 \%$ interest rate, and divided by the number of delivered tons to give the per ton cost of depot construction and infrastructure, which totaled $\$ 3.43 /$ dry ton.

\subsubsection{Cost Summary and Energy Usage}

Results of the supply chain analysis are summarized in Table 9, which provides the detailed cost components of the clean pine feedstock supply system for CFP. In our analysis, the clean pine was unable to meet the cost target of $\$ 85.51$ by $\$ 2.31$ dry ton. While it was unable to meet the cost target in our analysis, there could be some niche locations where it would be possible to deliver clean pine material the throat of the reactor for a cost of $\$ 85.51 /$ dry ton or less, but the number of these areas would be limited and not represent significant opportunity for industry growth.

Table 9. Summary of modeled cost estimates of the 2018 SOT woody feedstock supply system for clean pine supplied to CFP.

\begin{tabular}{|c|c|}
\hline \multicolumn{2}{|c|}{ Cost Summary (\$/Dry Ton) (2016\$) } \\
\hline & Mn10 CnT \\
\hline Grower Payment & $\cos 18$ \\
\hline Harvest \& Collection & $\$ 087$ \\
\hline Fieldside Preprocessing & \&) 8? \\
\hline Transportation & $\$ 2156$ \\
\hline Preprocessing & $\$ 9711$ \\
\hline Storage & enea \\
\hline Handling & $\sin 67$ \\
\hline Preprocessing Construction & $\$ 217$ \\
\hline Quality Dockage & $\operatorname{en} n \cap$ \\
\hline Grand Total & co7s \\
\hline
\end{tabular}

Table 10 presents the greenhouse gas emissions (GHG) for the clean pine for catalytic fast feedstock pathway. The greenhouse gas emissions analysis was completed by ANL, using energy consumption and transportation distance data from the BLM. ANL employed the Greenhouse Gases, Regulated Emissions, and Energy use in Transportation model (GREET ${ }^{\circledR}$ ) (Argonne National Laboratory, 2017) to conduct detailed life-cycle analysis of farm gate-to-biorefinery gate GHG emissions of the woody biomass scenarios presented in this report. GHG emissions remained constant from the 2017 SOT. 
Table 10. Summary of Greenhouse gas emissions for the 2018 SOT CFP woody feedstock supply system.

\begin{tabular}{|c|c|}
\hline \multicolumn{2}{|c|}{ Greenhouse Gas Emissions (kg $\mathrm{CO}_{2} \mathrm{e} / \mathrm{dry}$ ton) } \\
\hline Harvest \& Collection & 12764 \\
\hline Fieldside Preprocessing & 2215 \\
\hline Transportation & 41794 \\
\hline Preprocessing & 01177 \\
\hline Storage & noe \\
\hline Handling & 7286 \\
\hline Grand Total & 152.576 \\
\hline
\end{tabular}

\subsubsection{Sensitivity Analysis of Costs}

Sensitivity analysis was performed to determine the impact that alternate values for key operational parameters would have on the delivered cost presented as the 2018 SOT for clean pine delivered in to a catalytic fast pyrolysis. Energy consumption and throughput of the key preprocessing equipment were varied to explore the impact on total delivered cost per ton. The final set of sensitivity parameters consisted of the throughput of the chipper, densifier, rotary shear and pellet drier; the energy consumption of the chipper, densifier, rotary shear and pellet drier and the dry matter loss for the chipper and rotary shear. Each of the equipment parameters were varied based on variation seen in the processes, based on literature, from the values that were used in the final model run. The values ranges used for the sensitivity analysis are presented in Table 11, and the results are shown in Figure 5.

The cost of clean pine is most sensitive to the chipper capacity with a range in cost of $\$ 1.70$ from the high and low. A close second is densifier energy, which had a range of cost difference of $\$ 1.69$. The chipper and densifier account for the top four sensitivity factors. The cost of clean pine is least sensitive to dryer capacity, which had the smallest range of variation. 
Table 11. Sensitivity parameters for the 2018 SOT feedstock supply to the CFP pathway.

$\begin{array}{lccc} & \text { Min } & \text { Mean } & \text { Max } \\ \text { Dryer Capacity } & 4.74 \mathrm{odt} / \mathrm{hr} & 4.80 \mathrm{odt} / \mathrm{hr} & 4.89 \mathrm{odt} / \mathrm{hr} \\ \text { Dryer Energy } & 46.5 \mathrm{kWh} / \mathrm{t} & 50.0 \mathrm{kWh} / \mathrm{t} & 53.5 \mathrm{kWh} / \mathrm{t} \\ \text { Chipper Capacity } & 16.25 \mathrm{odt} / \mathrm{hr} & 25.00 \mathrm{odt} / \mathrm{hr} & 33.75 \mathrm{odt} / \mathrm{hr} \\ \text { Chipper Energy } & 16.02 \mathrm{kWh} / \mathrm{t} & 19.30 \mathrm{kWh} / \mathrm{t} & 22.58 \mathrm{kWh} / \mathrm{t} \\ \text { Chipper DML } & 4.5 \% & 5.0 \% & 4.5 \% \\ \text { Rotary Shear Capacity } & 7.05 \mathrm{otd} / \mathrm{hr} & 7.50 \mathrm{odt} / \mathrm{hr} & 7.95 \mathrm{odt} / \mathrm{hr} \\ \text { Rotary Shear Energy } & 31.85 \mathrm{kWh} / \mathrm{t} & 33.85 \mathrm{kWh} / \mathrm{t} & 35.97 \mathrm{kWh} / \mathrm{t} \\ \text { Rotary Shear DML } & 4.5 \% & 5.0 \% & 5.5 \% \\ \text { Densifier Capacity } & 4.5 \mathrm{odt} / \mathrm{hr} & 5.0 \mathrm{odt} / \mathrm{hr} & 5.5 \mathrm{odt} / \mathrm{hr} \\ \text { Densifier Energy } & 92.70 \mathrm{kWh} / \mathrm{t} & 103.0 \mathrm{kWh} / \mathrm{t} & 113.3 \mathrm{kWh} / \mathrm{t}\end{array}$

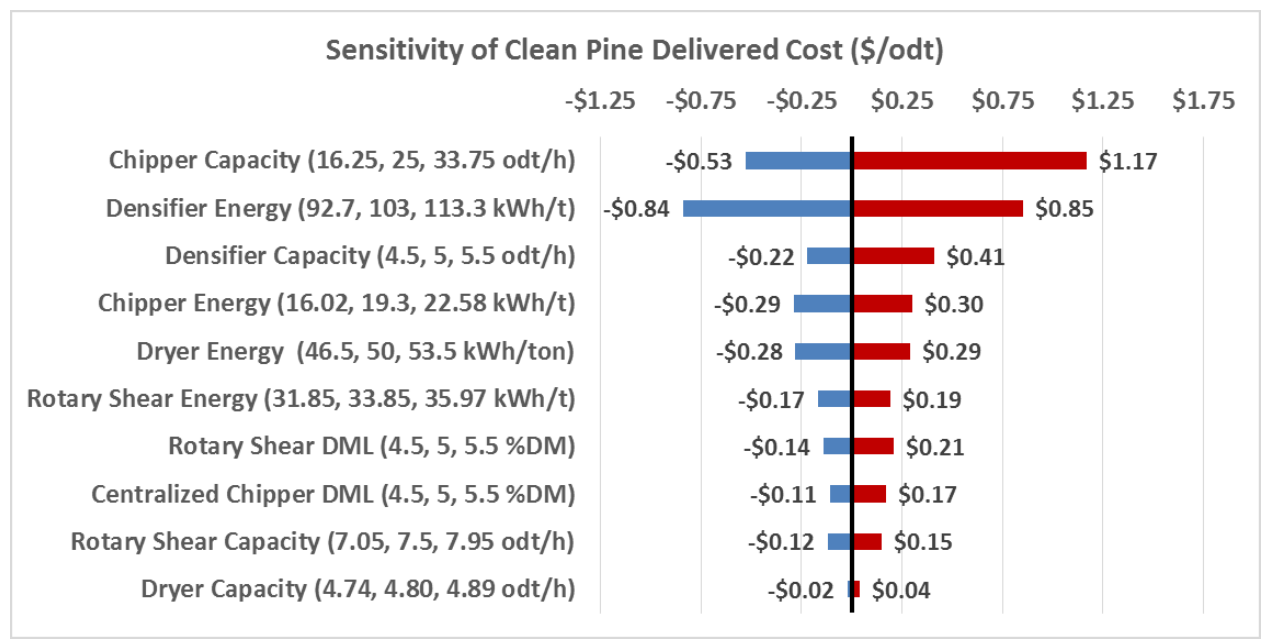

Figure 5. Sensitivity analysis of the delivered cost of the 2018 SOT feedstock for CFP. 


\subsubsection{Projection for Feedstock Supply to CFP}

\subsubsection{Description of Logistics System Designs}

The logistics system for 2022 delivers 725,000 dry tons of woody material made up of a blend of $25 \%$ clean pine and $75 \%$ logging residue that has been sequentially air classified to remove soil ash and the lights fraction leached to remove alkali and alkaline earth metals. The clean pine supply system is the same as that has been presented in the 2018 SOT for feedstock supply to CFP. The system harvests the log fractions of plantation grown pine and forest thinning material using a mechanized harvest system. The logs are sent to the processing facility where they are size reduced and densified before feeding into the conversion process. The logging residue system is similar to the system that has been presented for 2018 SOT for feedstock supply to IDL, with the addition of an air-classification and leaching system, drying and grinding to the smaller particle size specification.

\section{Grower Payment}

Grower payment represents the stumpage price paid to the landowner to secure permission to harvest the material. The grower payment was calculated using the size class stumpage values reported in the 2016 Billion Ton Report (BT16; USDOE, 2016) and. BT16 provides values of $\$ 32 /$ dry ton, $\$ 16 /$ dry ton and $\$ 8 /$ dry ton, for both planted and natural softwood stands, of size classes 1, 2 and 3, respectively in the Southern Region. Based on the assumed harvest region, the size class distribution of delivered material was $83 \%$ from size class 3 and $17 \%$ from size class 2 ; the resulting weighted average grower payment for clean pine is then calculated as $\$ 9.48 /$ dry ton. The calculation of forest residue grower payment utilizes the residue ratios from the USDA Forest Service Forest Inventory and Analysis Database (USDA Forest Service, 2017), to determine the proportion of the value of the whole tree stumpage that remains after the harvest as residue. Based on the assumed harvest region, the size class distribution of delivered material and residue ratio, the weighted average grower payment of Forest residue is $\$ 3.70$ /dry ton.

\section{Fieldside Operations}

Fieldside operations in this design are similar to those described previously in the clean pine section of this document. Felling is completed using a feller-buncher, and skidding with a grapple skidder. Operational characteristics of both pieces of equipment are based on descriptions resulting from the High Tonnage project completed by Auburn University (Sokhansanj et al., 2014). Delimbing is accomplished just prior to stacking for storage using a lower cost delimbing gate. Debarking is accomplished using a rotary head debarker at the depot, allowing removal of the costly and energy inefficient chain flail at the fieldside landing. It is worth noting that use of the delimbing gate resulted in reduced productivity of the grapple skidder, since the stems are manually forced through a metal grid by the skidder to remove the branches.

The forest residue is brought to the landing as part of the primary harvest operation and as such does not incur harvest or collection cost. Instead, the supply chain starts with size reduction 
of material that has been allowed to dry down to $30 \%$ moisture content in the field. Size reduction is performed with a mobile chipper, and the operational characteristics of the equipment are based on descriptions resulting from the High Tonnage project completed by Auburn University (Sokhansanj et al., 2014). The chips are blown directly into a truck for transport, eliminating the need for additional loading equipment.

\section{Preprocessing Operations}

The clean pine logs are unloaded from the trucks using a high-lift loader, and placed into storage piles. To initiate preprocessing, logs are delivered by loader to a rotary head debarker, and the debarked logs are conveyed to a 25 ton/hr disk chipper to produce an approximate 1-in nominal chip. The chips are conveyed to a rotary shear for the final size reduction, which provides better control of particle size distribution, and is impacted little by the moisture content of the biomass. The material exiting the rotary shear is conveyed to a surge bin, which feeds the pellet mill. The pellets are then conveyed to a cross flow grain dryer and dried to $10 \%$ moisture (wet basis).

The forest residue chips are delivered to the biorefinery by truck, where they are offloaded using a truck tipper with a hopper. From the hopper the chips are conveyed to storage piles. After leaving storage, the chips are passed through two stages of air classification. The first stage of air classification occurs at a fan speed of $10 \mathrm{~Hz}$ and is used to remove the majority of soil ash in the lights fraction and the fraction collected below the screen (i.e., sand and rocks too heavy to be fluidized in the airstream). The heavies fraction collected from the airstream is then air classified at a fan speed of $28 \mathrm{~Hz}$. The lights fraction from the second stage of air classification is then sent to dilute acid fill and drain leaching at ambient temperature and pressure to remove the majority of the alkali and alkaline earth metals in that fraction (alkali and alkaline earth metals reduce the yield of pyrolysis oil and poison the downstream upgrading catalyst in pyrolysis/upgrading processes). The leached lights fraction is dried to $10 \%$ moisture content using a rotary drier. The heavy fraction from the air classifier is dried to $10 \%$ moisture content using a rotary drier, and the dried leached lights and heavies are mixed back together, ground to the particle size specification by rotary shear and held in covered storage until feeding to the conversion process.

\section{Processing Location Construction Cost}

Preprocessing construction and infrastructure costs were estimated using the same method as in the 2017 SOT (Hartley et al. 2017). Hu et al. (2017) utilized construction and installation factors ranging from 1.43-1.7 to estimate the capital layout for construction and infrastructure for individual preprocessing equipment similar to the equipment in this design. For our calculations, we used the higher value of 1.7 for all preprocessing equipment to provide the more conservative estimate. Hence, the total capital layout for construction and infrastructure was estimated using an installation factor of 1.7 together with the installed capital cost of all preprocessing, handling and storage equipment; the estimate includes site preparation, construction, engineering and contingency (Hu et al. 2017). Land cost was calculated assuming 160 acres per depot at a cost of $\$ 500 /$ acre, and was added to the capital cost to determine the loan amount. The total cost was amortized over 30 years, assuming a 20\% down payment and an $8 \%$ interest rate, and divided by 


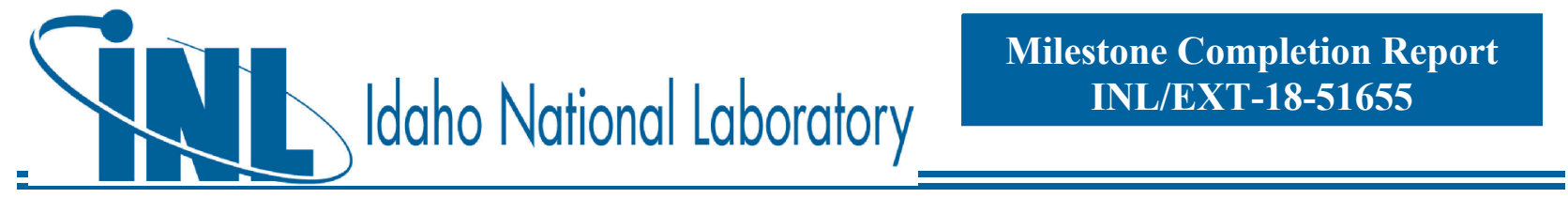

the number of delivered tons to give the per ton cost of depot construction and infrastructure, which totaled $\$ 3.43 /$ dry ton.

\subsubsection{Cost Summary and Energy Usage}

Results of the analyses are summarized in Table 12, which provides the detailed cost components of the clean pine feedstock supply system for catalytic fast pyrolysis.

Table 12. Summary of modeled cost estimates of the woody feedstock supply system for clean pine supplied to catalytic fast pyrolysis.

\begin{tabular}{|c|c|c|c|c|}
\hline \multicolumn{5}{|c|}{ Cost Summary (\$/Dry Ton) (2016\$) } \\
\hline & 2013 SOT & 2017 SOT & 2018 SOT & $\begin{array}{c}2022 \\
\text { Projection }\end{array}$ \\
\hline Grower Payment & $\$ 26.71$ & $\$ 9.48$ & $\$ 9.48$ & $\$ 7.64$ \\
\hline Harvest \& Collection & $\$ 23.77$ & $\$ 9.87$ & $\$ 9.87$ & $\$ 2.47$ \\
\hline Fieldside Preprocessing & $\$ 13.01$ & $\$ 2.82$ & $\$ 2.82$ & $\$ 9.81$ \\
\hline Transportation & $\$ 14.50$ & $\$ 31.56$ & $\$ 31.56$ & $\$ 13.32$ \\
\hline Preprocessing & $\$ 29.76$ & $\$ 27.14$ & $\$ 27.14$ & $\$ 31.12$ \\
\hline Storage & $\$ 0$ & $\$ 0.86$ & $\$ 0.86$ & $\$ 0.58$ \\
\hline Handling & $\$ 1.38$ & $\$ 2.62$ & $\$ 2.62$ & $\$ 2.09$ \\
\hline Preprocessing Construction & - & $\$ 3.47$ & $\$ 3.47$ & $\$ 3.28$ \\
\hline Quality Dockage & - & $\$ 0.00$ & $\$ 0.00$ & $\$ 0.00$ \\
\hline Grand Total & $\$ 109.13$ & $\$ 87.82$ & $\$ 87.82$ & $\$ 70.31$ \\
\hline
\end{tabular}

Delivered feedstock costs for the 2013 SOT, 2017 SOT, 2018 SOT and 2022 Projection for CFP are shown in Figure 6.

Table 13 presents the greenhouse gas emissions (GHG) for the clean pine for catalytic fast feedstock pathway. The greenhouse gas emissions analysis was completed by ANL, using energy consumption and transportation distance data from the BLM. ANL employed the Greenhouse Gases, Regulated Emissions, and Energy use in Transportation model (GREET ${ }^{\circledR}$ ) (Argonne National Laboratory, 2017) to conduct detailed life-cycle analysis of farm gate-to-biorefinery gate GHG emissions of the woody biomass scenarios presented in this report. GHG emissions remained constant from the 2017 SOT. 

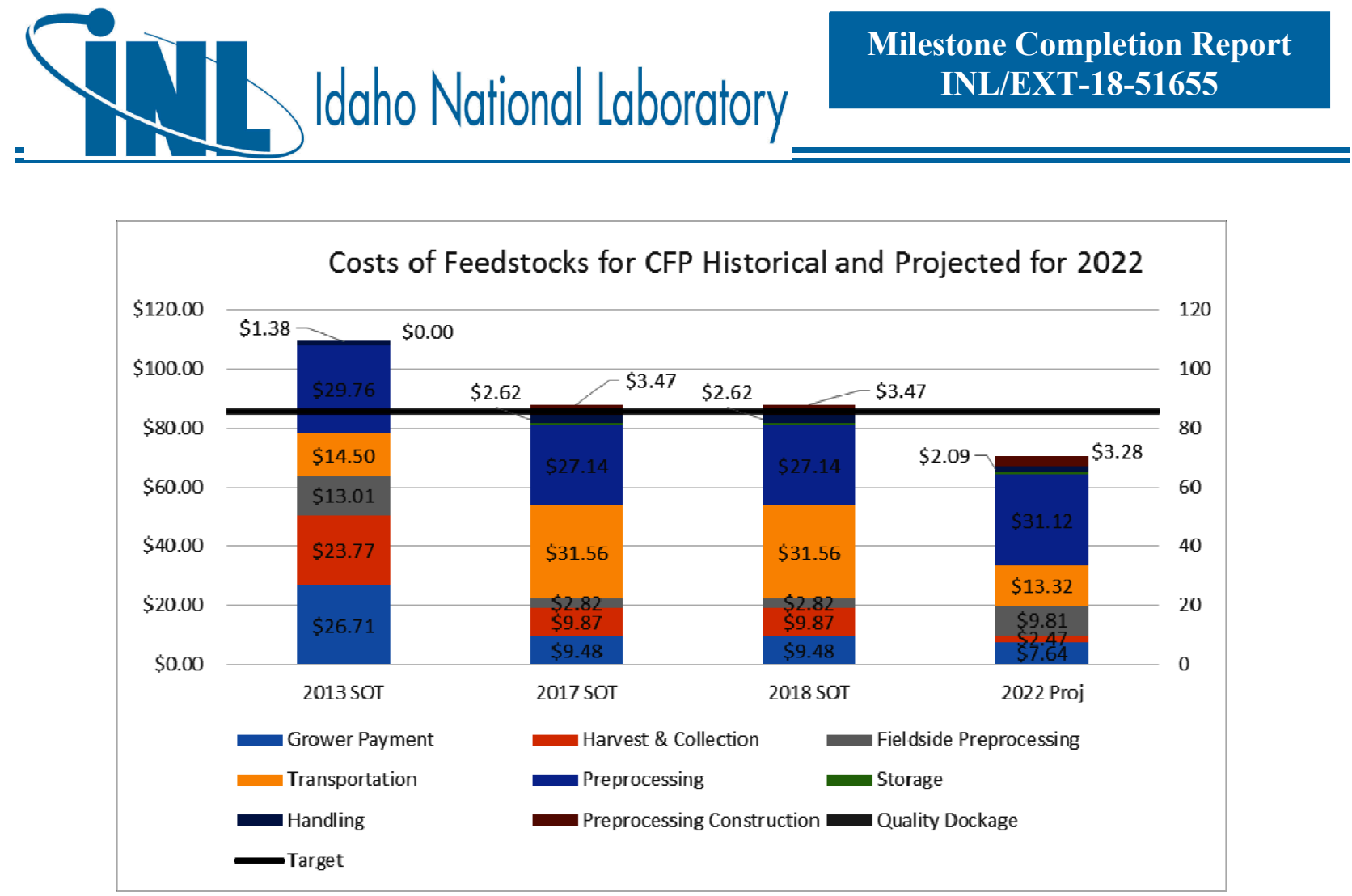

Figure 6. Waterfall chart for feedstock prices for catalytic fast pyrolysis.

Table 13. Summary of Greenhouse gas emissions for the 2022 Projection for CFP woody feedstock supply.

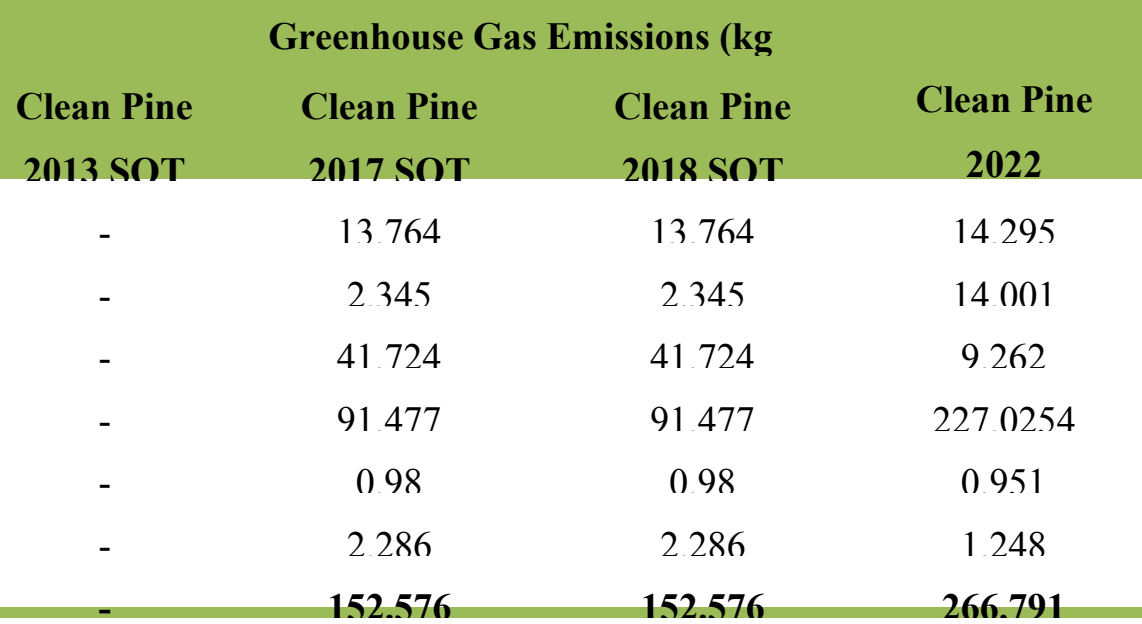

\subsubsection{Sensitivity Analysis of Costs}

Sensitivity analysis was performed to determine the impact that alternate values for key operational parameters would have on the delivered cost presented as the 2022 Projection for CFP delivered in to a catalytic fast pyrolysis. Energy consumption and throughput of the key preprocessing equipment were varied to explore the impact on total delivered cost per ton. The 
final set of sensitivity parameters consisted of the throughput of the chipper, densifier, rotary shear and pellet drier; the energy consumption of the chipper, densifier, rotary shear and pellet drier and the dry matter loss for the chipper and rotary shear. Each of the equipment parameters were varied based on variation seen in the processes, based on literature, from the values that were used in the final model run. The values ranges used for the sensitivity analysis are presented in Table 14; the results are shown in Figure 7.

Table 14. Sensitivity parameters for the 2022 Projection feedstock supply to the CFP pathway.

$\begin{array}{lccc} & \text { Min } & \text { Mean } & \text { Max } \\ \text { Fieldside Chipping Capacity } & 76.37 \mathrm{odt} / \mathrm{hr} & 79.80 \mathrm{odt} / \mathrm{hr} & 83.00 \mathrm{odt} / \mathrm{hr} \\ \text { Fieldside Chipping Energy } & 13.20 \mathrm{kWh} / \mathrm{t} & 18.50 \mathrm{kWh} / \mathrm{t} & 26.50 \mathrm{kWh} / \mathrm{t} \\ \text { Dryer Capacity } & 1.48 \mathrm{odt} / \mathrm{hr} & 1.5 \mathrm{odt} / \mathrm{hr} & 1.53 \mathrm{odt} / \mathrm{hr} \\ \text { Dryer Energy } & 325.50 \mathrm{kWh} / \mathrm{t} & 350.00 \mathrm{kWh} / \mathrm{t} & 374.50 \mathrm{kWh} / \mathrm{t} \\ \text { Central Chipper Capacity } & 16.25 \mathrm{odt} / \mathrm{hr} & 25.00 \mathrm{odt} / \mathrm{hr} & 33.75 \mathrm{odt} / \mathrm{hr} \\ \text { Central Chipper Energy } & 46.50 \mathrm{kWh} / \mathrm{t} & 50.00 \mathrm{kWh} / \mathrm{t} & 53.50 \mathrm{kWh} / \mathrm{t} \\ \text { Central Chipper DML } & 4.50 \% & 5.00 \% & 4.50 \% \\ \text { Rotary Shear Capacity } & 7.050 \mathrm{otd} / \mathrm{hr} & 7.50 \mathrm{odt} / \mathrm{hr} & 7.95 \mathrm{odt} / \mathrm{hr} \\ \text { Rotary Shear Energy } & 31.85 \mathrm{kWh} / \mathrm{t} & 33.85 \mathrm{kWh} / \mathrm{t} & 35.97 \mathrm{kWh} / \mathrm{t} \\ \text { Rotary Shear DML } & 4.50 \% & 5.00 \% & 5.50 \% \\ \text { Air Classifier DMT } & 6.00 \% & 6.50 \% & 7.50 \%\end{array}$

The cost of blended material for the 2022 Projection is most sensitive to the energy consumption of the fieldside chipper with an effect on costs ranging from a reduction of $\$ 1.16$ to an increase of $\$ 0.89$ per dry ton. The energy consumption has an impact of the next most impactful parameter the drier energy, which had an average impact of $+/-\$ 0.42 /$ dry ton. Ultimately, the loss of material in the air classification and size reduction steps had relatively small impact, with rotary shear having the largest impact of $-\$ 0.17$ /dry ton and $+\$ 0.21 /$ dry ton. The higher impact of the losses of the rotary shear are due to the accumulated cost that have occurred prior to arriving at the rotary shear. 

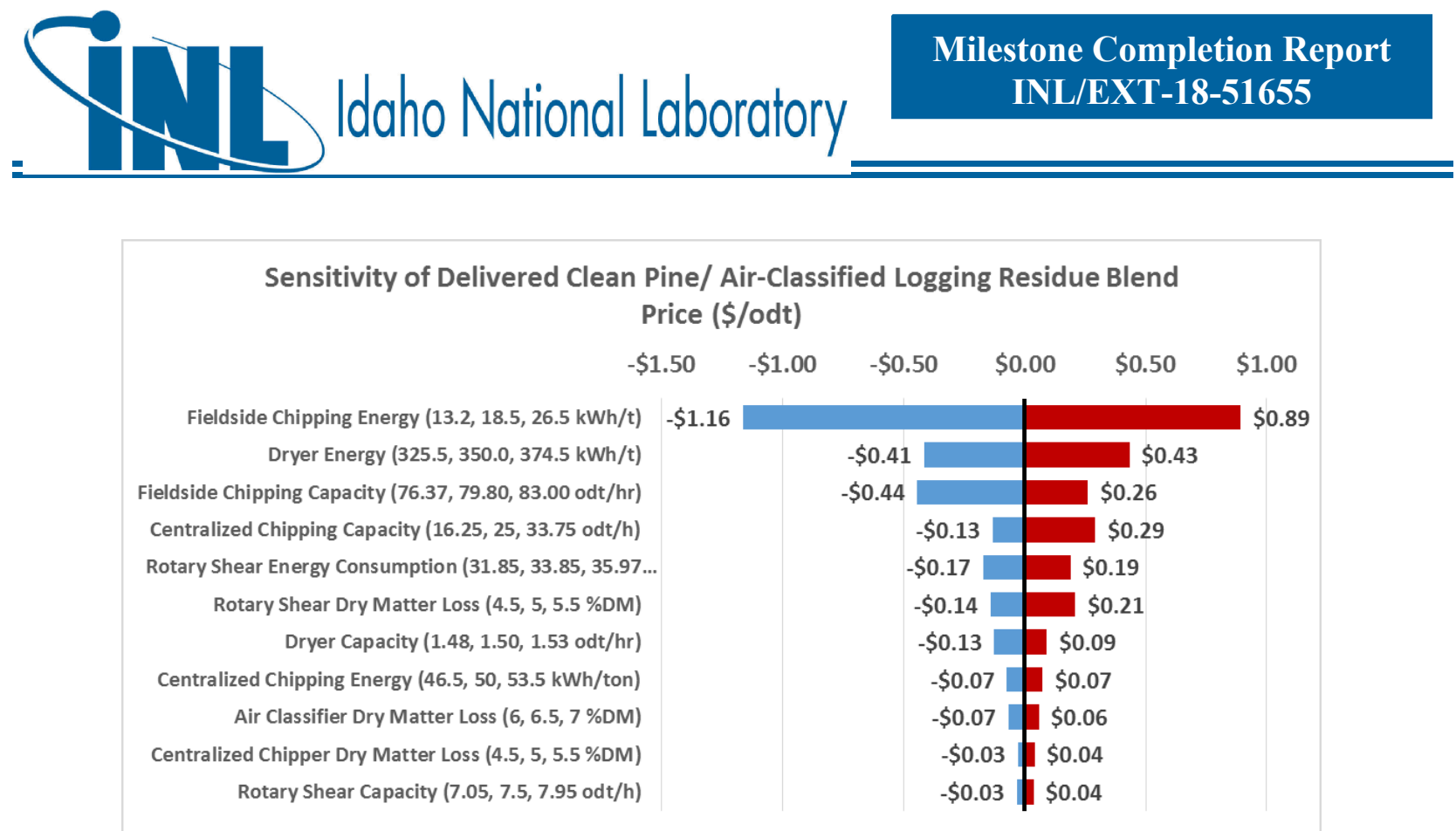

Figure 7. Sensitivity analysis of the delivered cost of the 2022 Projection feedstock blend for CFP. 


\subsection{Feedstock Supply Systems for Algal-blend Hydrothermal Liquefaction (AHTL)}

The 2018 and 2022 AHTL conversion pathway assumes 1nnual nth plant delivery of 35,752 dry tons of woody feedstock for inclusion in a 90\% algae-10\% woody feedstock blend, with total ash $\leq 3 \mathrm{wt} \%$, moisture content $\leq 10 \%$ (wet basis), and particle size of less than $1 / 4^{\prime \prime}$-minus (Table 15 ). The AHTL pathway has a delivered feedstock cost target of $\$ 70.35 /$ dry ton $(2016 \$)$ in 2022 , including dockage.

Table 15. Delivered feedstock composition assumptions for AHTL.

\begin{tabular}{|lc|}
\hline Carbon & Composition \\
\hline Hydrogen & 49.81 \\
Nitrogen & 5.91 \\
Sulfur & 0.17 \\
Oxygen & 0.09 \\
\hline Ash & 41.02 \\
\hline Heating Value (Btu/lb) & 3.00 \\
\hline Moisture (Bulk Wt. \%) & $8,449 \mathrm{HHV}$ \\
Particle Size (inches) & $7,856 \mathrm{LHV}$ \\
\hline
\end{tabular}

\subsubsection{SOT for Logging Residue Supply to AHTL}

\subsubsection{Description of Logistic System Designs}

The 2018 woody SOT is reported in 2016 dollars (2016\$) and includes both grower payment and logistics costs to reflect a total delivered feedstock supply cost. This report outlines the 2018 woody SOT design that was capable of achieving a modeled delivered feedstock cost of $\$ 70.35 /$ dry ton. Logistics costs include harvest, collection, storage, transportation, and preprocessing costs from the point of harvest to the conversion reactor throat in-feed. Grower payment represents the stumpage payment and includes the cost of production, compensation for soil nutrient removal, and grower profit. The IDL process has less stringent quality and particle size requirements than that of pyrolysis, resulting in a simple preprocessing design along with the utilization of considerably cheaper forest residues. 
The logistics system for the 2018 SOT, delivering 35,752 dry tons of forest residue, is the same that was described in the 2017 SOT report (Hartley et al., 2017). The AHTL system places fewer restrictions on the feedstock specifications, in terms of particle size and ash content; which removed the necessity of much of the preprocessing required in the previous analyses.

\section{Grower Payment}

Grower payment represents the stumpage price paid to the landowner to secure permission to harvest the material. The grower payment was calculated using the size class stumpage values reported in the 2016 Billion Ton Report (BT16; USDOE, 2016). BT16 provides values of $\$ 32.40$ /dry ton, $\$ 16.20$ /dry ton and $\$ 8.10$ /dry ton, for both planted and natural softwood stands, of size classes 1, 2 and 3, respectively, in the Southern Region. The calculation of forest residue grower payment utilizes the residue ratios from the USDA Forest Service Forest Inventory and Analysis Database (USDA Forest Service, 2017), to determine the proportion of the value of the whole tree stumpage that remains after the harvest as residue. Based on the assumed harvest region, the size class distribution of delivered material and residue ratio, the weighted average grower payment of Forest residue is $\$ 3.75 /$ dry ton.

\section{Fieldside Operations}

2018 fieldside operations in this design are the same as those presented in the 2017 SOT for gasification (Hartley et al., 2017). As before, it is assumed that the forest residue is brought to the landing as part of the primary harvest operation and as such does not incur harvest or collection cost. Instead, the supply chain starts with size reduction of material that has been dried to $30 \%$ moisture content in the field. Size reduction is performed with a mobile chipper, and the operational characteristics of the equipment are based on descriptions resulting from the High Tonnage project completed by Auburn University (Sokhansanj et al., 2014). The chips are blown directly into a truck for transport, eliminating the need for additional loading equipment.

\section{Biorefinery Operations}

The forest residue chips are delivered to the refinery by truck, where they are offloaded using a truck tipper with a hopper. From the hopper the chips are conveyed to storage piles until they are dried using a rotary drier. After drying the chips to $10 \%$ moisture content, the chips are held in covered storage until feeding to the conversion process.

\section{Processing Location Construction Cost}

Construction and infrastructure costs were estimated as follows. Hu et al. (2017) utilized installation factors ranging from 1.43-1.7 to estimate the capital layout for construction and infrastructure for individual preprocessing equipment similar to the equipment in this design. For our calculations, we used the higher value of 1.7 for all preprocessing equipment to provide the more conservative estimate. Hence, the total capital layout for construction and infrastructure was estimated using an installation factor of 1.7 together with the installed capital cost of all preprocessing, handling and storage equipment; the estimate includes site preparation, construction, engineering and contingency (Hu et al. 2017). Land cost was calculated assuming 160 acres per depot at a cost of $\$ 500 /$ acre, and was added to the capital cost to determine the loan amount. The total cost was amortized over 30 years, assuming a $20 \%$ down payment and an 


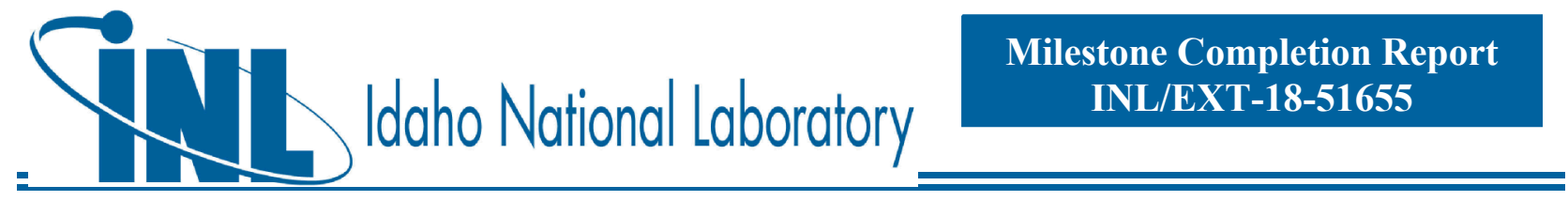

$8 \%$ interest rate, and divided by the number of delivered tons to give the per ton cost of depot construction and infrastructure, which totaled $\$ 2.73 /$ dry ton.

\subsubsection{Cost Summary and Energy Usage}

Results of the supply chain analysis are summarized in Table 16, which provides the detailed cost components.

Table 16. Summary of modeled cost estimates of the 2018 SOT woody feedstock supply system for logging residues supplied to AHTL.

\begin{tabular}{|c|c|}
\hline \multicolumn{2}{|c|}{ Cost Summary (\$/Dry Ton) (2016\$) } \\
\hline & $\begin{array}{c}\text { AHTL } \\
\text { gme cot }\end{array}$ \\
\hline Grower Payment & $\$ 3.75$ \\
\hline Harvest \& Collection & $\$ 0.00$ \\
\hline Fieldside Preprocessing & $\$ 11.53$ \\
\hline Transportation & $\$ 5.89$ \\
\hline Preprocessing & $\$ 39.82$ \\
\hline Storage & $\$ 0.67$ \\
\hline Handling & $\$ 3.70$ \\
\hline Preprocessing Construction & $\$ 4.95$ \\
\hline Quality Dockage & $\$ 0.00$ \\
\hline Grand Total & $\$ 70.31$ \\
\hline
\end{tabular}

Table 17 presents the greenhouse gas emissions (GHG) for each feedstock pathway. The greenhouse gas emissions analysis was completed by ANL, using energy consumption and transportation distance data from the BLM. ANL employed the Greenhouse Gases, Regulated Emissions, and Energy use in Transportation model (GREET ${ }^{\circledR}$ ) (Argonne National Laboratory, 2017) to conduct detailed life-cycle analysis of farm gate-to-biorefinery gate GHG emissions of the woody biomass scenarios presented in this report.

\subsubsection{Sensitivity Analysis of Costs}

Sensitivity analysis was performed to determine the impact that alternate values for key operational parameters would have on the delivered cost presented as the 2018 SOT Design for supply of logging residues to AHTL. The feedstock utilized in the final design required only minimal processing in order to be suitable for use in conversion. This resulted in a set of 
Table 17. Summary of Greenhouse gas emissions for the 2018 SOT AHTL woody feedstock supply.

\begin{tabular}{lc}
\multicolumn{2}{c}{ Greenhouse Gas Emissions (kg $\mathrm{CO}_{2} \mathrm{e} / \mathrm{dry}$ ton) } \\
AHTL \\
Harvest \& Collection & 0.000 \\
Fieldside Preprocessing & 24.876 \\
Transportation from Fieldside & 2.360 \\
Preprocessing & 53.200 \\
Storage & 0.858 \\
Handling & 1.969 \\
Grand Total & $\mathbf{8 3 . 2 6 3}$ \\
\hline
\end{tabular}

relatively few model parameters that were considered to potentially have impact on the final delivered price. Model parameters were chosen that could be variable or could cause variability in the preprocessing operations and ultimately cost. The final set of sensitivity parameters consisted of the final ash content of the material, the throughput of the chipper at the roadside, the energy consumption of the chipper at the roadside, the dryer throughput at the biorefinery, and the energy consumption of the dryer at the biorefinery. Each of the equipment parameters were varied based on variation seen in the processes, based on literature, from the values that were used in the final model run (Cao et al., 2007; Spinelli et al., 2012; Thompson et al. 2013). The values used are presented in Table 18.

Table 18. Sensitivity parameters for the 2018 SOT for feedstock supply to AHTL.

\begin{tabular}{lccc} 
& Min & Mean & Max \\
Dryer Capacity & $1.48 \mathrm{odt} / \mathrm{hr}$ & $1.5 \mathrm{odt} / \mathrm{hr}$ & $1.53 \mathrm{odt} / \mathrm{hr}$ \\
Dryer Energy & $325.5 \mathrm{kWh} / \mathrm{t}$ & $350 \mathrm{kWh} / \mathrm{t}$ & $374.5 \mathrm{kWh} / \mathrm{t}$ \\
Chpper Capacity & $76.37 \mathrm{odt} / \mathrm{hr}$ & $79.80 \mathrm{odt} / \mathrm{hr}$ & $83.00 \mathrm{odt} / \mathrm{hr}$ \\
Chipper Energy & $13.2 \mathrm{kWh} / \mathrm{t}$ & $18.5 \mathrm{kWh} / \mathrm{t}$ & $26.5 \mathrm{kWh} / \mathrm{t}$ \\
\hline
\end{tabular}

Figure 8 presents the results of the sensitivity analysis. The delivered cost is most sensitive to chipper energy consumption, followed by the throughput of the chipper equipment. The impact of energy consumption on the chipper is because of the relative uncertainty that can be seen when processing material. The impact of throughput has to do with the distributing the cost of the piece of equipment over the amount of material that is processed. When the throughput is decreased the cost increases, while when throughput increases the cost decreases. 

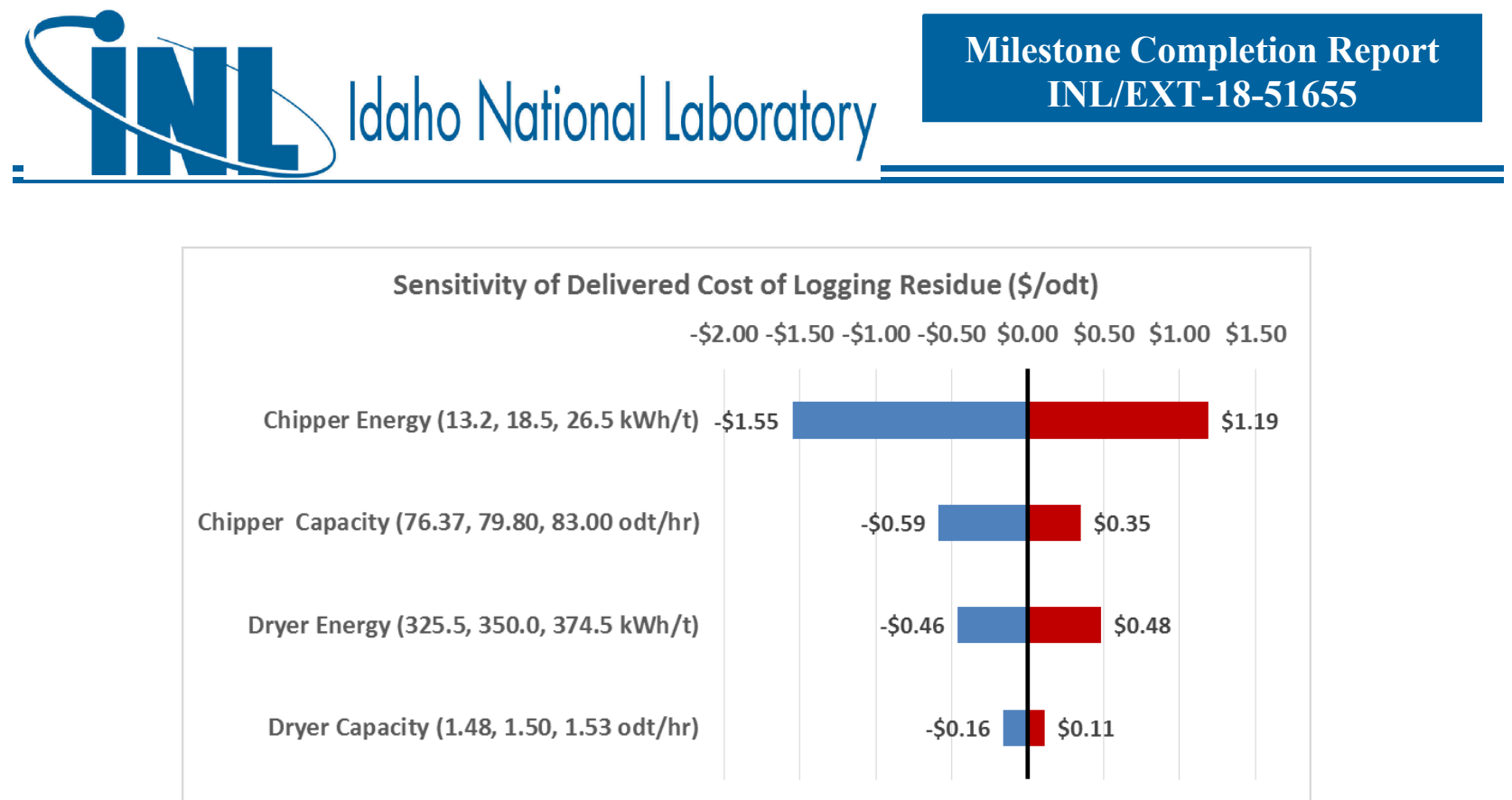

Figure 8. Tornado chart showing sensitivity of cost to operational parameters used to model the 2018 SOT Case for AHTL. 


\subsubsection{Projection for Logging Residue Supply to AHTL}

\subsubsection{Description of Logistic System Designs}

The logistics system for the 2022 Projection delivers only forest residue is the same that was described in the 2017 SOT report (Hartley et al., 2017) and is used in the 2018 SOT.

\section{Grower Payment}

Grower payment represents the stumpage price paid to the landowner to secure permission to harvest the material. The grower payment was calculated using the size class stumpage values reported in the 2016 Billion Ton Report (BT16; USDOE, 2016). BT16 provides values of $\$ 32.40$ /dry ton, $\$ 16.20 /$ dry ton and $\$ 8.10 /$ dry ton, for both planted and natural softwood stands, of size classes 1, 2 and 3, respectively, in the Southern Region. The calculation of forest residue grower payment utilizes the residue ratios from the USDA Forest Service Forest Inventory and Analysis Database (USDA Forest Service, 2017), to determine the proportion of the value of the whole tree stumpage that remains after the harvest as residue. Based on the assumed harvest region, the size class distribution of delivered material and residue ratio, the weighted average grower payment of Forest residue is $\$ 3.75 /$ dry ton.

\section{Fieldside Operations}

2022 fieldside operations in this design are the same as those presented in the 2018 SOT for AHTL. As before, it is assumed that the forest residue is brought to the landing as part of the primary harvest operation and as such does not incur harvest or collection cost. Instead, the supply chain starts with size reduction of material that has been dried to $30 \%$ moisture content in the field. Size reduction is performed with a mobile chipper, and the operational characteristics of the equipment are based on descriptions resulting from the High Tonnage project completed by Auburn University (Sokhansanj et al., 2014). The chips are blown directly into a truck for transport, eliminating the need for additional loading equipment.

\section{Biorefinery Operations}

The forest residue chips are delivered to the refinery by truck, where they are offloaded using a truck tipper with a hopper. From the hopper the chips are conveyed to storage piles until they are dried using a rotary drier. After drying the chips to $10 \%$ moisture content, the chips are held in covered storage until feeding to the conversion process.

\section{Processing Location Construction Cost}

Construction and infrastructure costs were estimated as follows. Hu et al. (2017) utilized installation factors ranging from 1.43-1.7 to estimate the capital layout for construction and infrastructure for individual preprocessing equipment similar to the equipment in this design. For our calculations, we used the higher value of 1.7 for all preprocessing equipment to provide the more conservative estimate. Hence, the total capital layout for construction and infrastructure was estimated using an installation factor of 1.7 together with the installed capital cost of all preprocessing, handling and storage equipment; the estimate includes site preparation, construction, engineering and contingency (Hu et al. 2017). Land cost was calculated assuming 


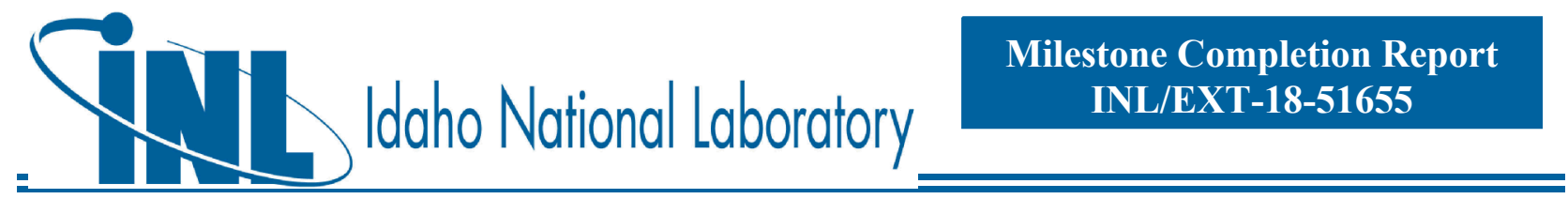

160 acres per depot at a cost of $\$ 500 /$ acre, and was added to the capital cost to determine the loan amount. The total cost was amortized over 30 years, assuming a $20 \%$ down payment and an $8 \%$ interest rate, and divided by the number of delivered tons to give the per ton cost of depot construction and infrastructure, which totaled $\$ 2.73 /$ dry ton.

\subsubsection{Cost Summary and Energy Usage}

Results of the analyses are summarized in Table 19, Figure 9 and Table 20 below. Table 19 provides the detailed cost components for the 2018 SOT and the projection for 2022, with a waterfall chart of the information presented in Figure 9. It can be noticed that the cost of the 2022 Projection increases over the 2017 and 2018 SOTs. The reason for this is that the projected availability of logging residue is projected to decrease into the future. The decrease in material, necessitates a greater travel distance and a greater cost of transportation.

Table 19. Summary of modeled cost estimates for the woody feedstock supply systems providing feedstocks to AHTL for the 2018 SOT and 2022 Projection.

\begin{tabular}{|c|c|c|}
\hline \multicolumn{3}{|c|}{ Cost Summary (\$/Dry Ton) (2016\$) } \\
\hline & $\begin{array}{c}\text { AHTL } \\
\text { 2018 SOT }\end{array}$ & $\begin{array}{c}\text { AHTL } \\
\text { 2022 Prniection }\end{array}$ \\
\hline Grower Payment & $\$ 3.75$ & $\$ 3.75$ \\
\hline Harvest \& Collection & $\$ 0.00$ & $\$ 0.00$ \\
\hline Fieldside Preprocessing & $\$ 11.53$ & $\$ 11.53$ \\
\hline Transportation & $\$ 5.89$ & $\$ 5.89$ \\
\hline Preprocessing & $\$ 39.82$ & $\$ 39.82$ \\
\hline Storage & $\$ 0.67$ & $\$ 0.67$ \\
\hline Handling & $\$ 3.70$ & $\$ 3.70$ \\
\hline Preprocessing Construction & $\$ 4.95$ & $\$ 4.95$ \\
\hline Quality Dockage & $\$ 0.00$ & $\$ 0.00$ \\
\hline Grand Total & $\$ 70.31$ & $\$ 70.31$ \\
\hline
\end{tabular}

Table 20 presents the greenhouse gas emissions (GHG) for the 2018 SOT and the projected 2022 case. 

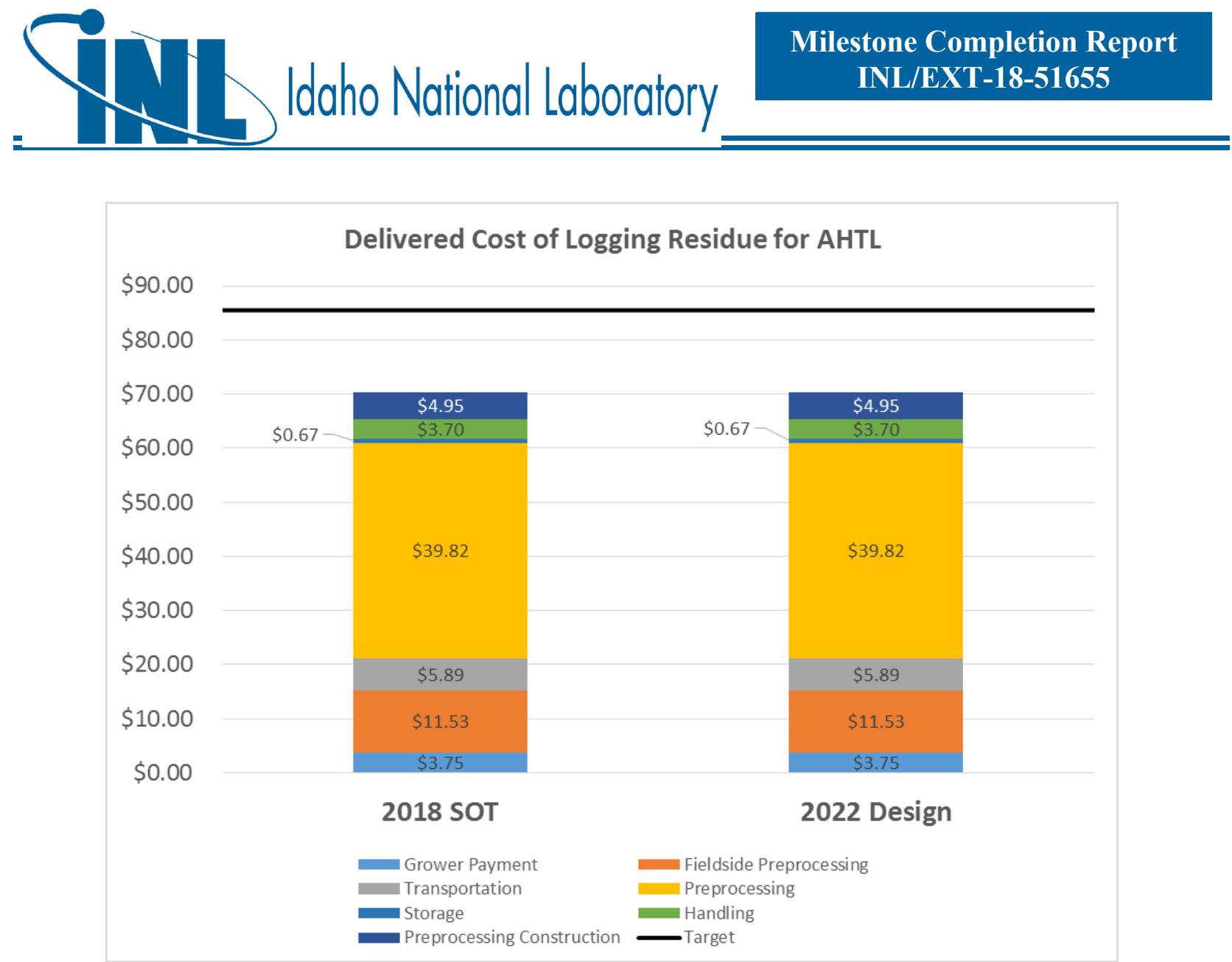

Figure 9. Water fall chart of delivered chipped logging residue costs to the AHTL process in 2018 and projected for 2022.

Table 20. Summary of Greenhouse gas emissions for woody feedstock supply to AHTL for the 2018 SOT and 2022 Projection.

\begin{tabular}{lcc}
\multicolumn{3}{c}{ Greenhouse Gas Emissions (kg CO $2 \mathrm{e} /$ dry ton) } \\
& AHTL & AHTL \\
& $\mathbf{2 0 1 8 \text { SOT }}$ & onom Drninntion \\
Harvest \& Collection & 0.000 & 0.000 \\
Fieldside Preprocessing & 24.876 & 24.876 \\
Transportation & 12.755 & 15.875 \\
Preprocessing & 25.920 & 25.920 \\
Storage & 0.858 & 0.858 \\
Handling & 1.969 & 1.969 \\
Grand Total & $\mathbf{6 6 . 3 9 3}$ & $\mathbf{6 9 . 5 1 3}$
\end{tabular}




\subsubsection{Sensitivity Analysis of Costs}

Sensitivity analysis was performed to determine the impact that alternate values for key operational parameters would have on the delivered cost presented as the 2022 Projection for logging residue supply to AHTL. The feedstock utilized in the final design required only minimal processing in order to be suitable for use in AHTL. This resulted in a set of relatively few model parameters that were considered to potentially have impact on the final delivered price. Model parameters were chosen that could be variable or could cause variability in the preprocessing operations and ultimately cost. The final set of sensitivity parameters consisted of the final ash content of the material, the throughput of the chipper at the roadside, the energy consumption of the chipper at the roadside, the dryer throughput at the biorefinery, and the energy consumption of the dryer at the biorefinery. Each of the equipment parameters were varied based on variation seen in the processes, based on literature, from the values that were used in the final model run (Cao et al., 2007; Spinelli et al., 2012; Thompson et al. 2013). The values used are presented in Table 21.

Table 21. Sensitivity parameters for the 2022 Projection feedstock supply to the AHTL pathway.

\begin{tabular}{lccc} 
& Min & Mean & Max \\
Dryer Capacity & $1.48 \mathrm{odt} / \mathrm{hr}$ & $1.5 \mathrm{odt} / \mathrm{hr}$ & $1.53 \mathrm{odt} / \mathrm{hr}$ \\
Dryer Energy & $325.5 \mathrm{kWh} / \mathrm{t}$ & $350 \mathrm{kWh} / \mathrm{t}$ & $374.5 \mathrm{kWh} / \mathrm{t}$ \\
Chpper Capacity & $76.37 \mathrm{odt} / \mathrm{hr}$ & $79.80 \mathrm{odt} / \mathrm{hr}$ & $83.00 \mathrm{odt} / \mathrm{hr}$ \\
Chipper Energy & $13.2 \mathrm{kWh} / \mathrm{t}$ & $18.5 \mathrm{kWh} / \mathrm{t}$ & $26.5 \mathrm{kWh} / \mathrm{t}$ \\
\hline
\end{tabular}

Figure 10 presents the results of the sensitivity analysis. The delivered cost is most sensitive to chipper energy consumption, followed by the throughput of the chipper equipment. The impact of energy consumption on the chipper is because of the relative uncertainty that can be seen when processing material. The impact of throughput has to do with the distributing the cost of the piece of equipment over the amount of material that is processed. When the throughput is decreased the cost increases, while when throughput increases the cost decreases. 

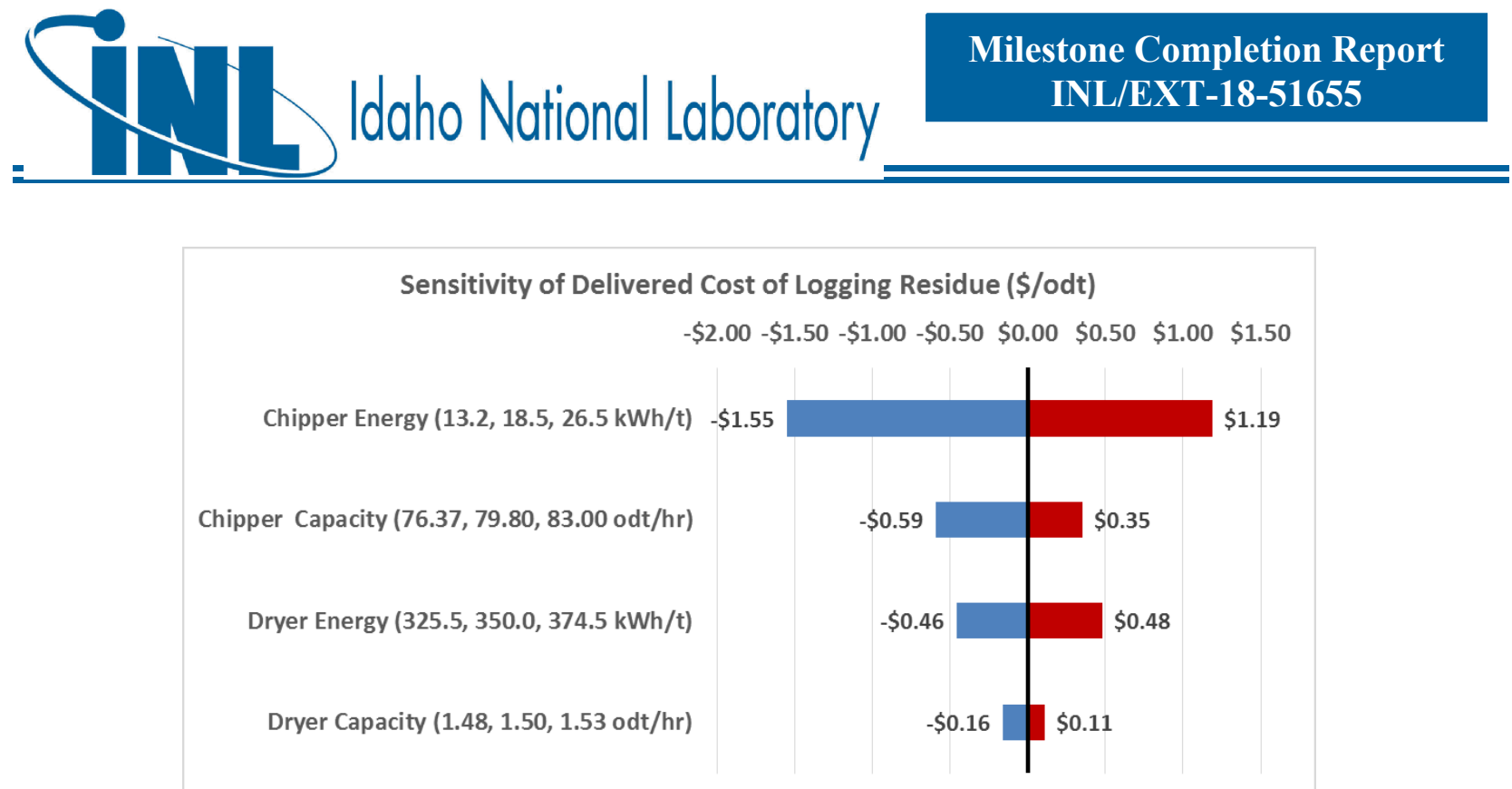

Figure 10. Tornado chart showing sensitivity of cost to operational parameters used to model the 2022 Projection for feedstock supply to AHTL. 


\section{INDUSTRIAL RELEVANCE OF THE FEEDSTOCKS}

Logging Residues

Currently nationwide, there are 9,414,172 dry tons of pine forest residues. The use of Forest residue is qualified by EPA to be eligible for RINs (USEPA, 2010). This scenario estimates a total of 35.9 million tons available nationwide at this cost of $\$ 59.76$. If we consider only the volume that is aggregable within a 725,000 ton supply shed and ignore "stranded" resources, there are enough forest residues to supply 17 biorefineries.

Clean Pine

Currently, it is estimated that there are 21,218,792 dry tons of pine feedstocks available nationally, with 11,804,620 dry tons of planted pine and 9,414,172 dry tons of pine forest residues. Plantation grown pine is the only type of pine that is currently known to be qualified for the production of RINs. However, the amount of material that can be aggregated at a cost of approximately $\$ 87 /$ dry ton to the reactor throat is only enough to support 8 biorefineries, given no competition for the resource.

\section{QUALIFICATION OF THE FEEDSTOCKS FOR RENEWABLE IDENTIFICATION NUMBERS}

The Environmental Protection Agency revised the National Renewable Fuel Standard Program in 2010 to implement the requirements of the Energy Security and Independence Act of 2007 (EISA). The revision of the program became known as RFS2, and mandated the use of 36 billion gallons of renewable fuel by 2022. As part of the revised rules, definitions of qualified biofuel feedstocks were outlined; the revised rules stipulated that "renewable fuels" had to be made from materials that qualify as renewable biomass. To be considered renewable biomass the materials must conform to the specified types and land types from where they are harvested as directed by EISA. From the final rule published in Vol 75, No. 58 of the Federal Register on page 14681 .

"The definition includes:

- Planted crops and crop residue from agricultural land cleared prior to December 19, 2007 and actively managed or fallow on that date.

- Planted trees and tree residue from tree plantations cleared prior to December 19, 2007 and actively managed on that date.

- Animal waste material and byproducts.

- Slash and pre-commercial thinnings from non-federal forestlands that are neither oldgrowth nor listed as critically imperiled or rare by a State Natural Heritage program.

- Biomass cleared from the vicinity of buildings and other areas at risk of wildfire. 
- Algae.

- Separated yard waste and food waste."

Thermochemical conversion focuses primarily on woody materials. Specifically the qualification must be examined for the two potential feedstock sources that were considered: clean pine and forest residue. Clean pine, pine wood containing less than $2 \%$ bark, could potentially be sourced from both plantation and forest sources. Clean pine will generally be produced from stem sections of whole trees. The qualification of plantation material is directly addressed in Section II.B.4.a.ii on page 14694. EISA defines “...planted trees and tree residue from actively managed tree plantations on non-federal land cleared at any time prior to December 19, 2007, including land belonging to an Indian tribe or an Indian individual, that is held in trust by the United States or subject to a restriction against alienation imposed by the United States."; as renewable biomass. While a plantation has been defined as, "a stand of no less than 1 acre composed primarily of trees established by hand- or machine-planting of seed or sapling, or by coppice growth from the stump or root of a tree that was hand- or machineplanted." From these definitions, practically all non-federal sources of cultivated trees would qualify as a renewable biomass and thus qualify for RINS.

The ability to source clean pine material from natural forest is more limited, but still possible based on Section II.B.4.a.iii on page 14695 and Section II.B.4.iv on page 14696. These two sections describe the conditions necessary to qualify from traditional forestry operations and/or as operations that are protecting from wild fire. In order to source clean pine from natural forest, that are not under the risk of wildfire, the following conditions must be met: 1) Be the result of pre-commercial thinning or residue from a commercial harvest; 2) be, " from non-federal forestlands, including forestlands belonging to an Indian tribe or an Indian individual, that are held in trust by the United States or subject to a restriction against alienation imposed by the United States"; 3) the material must not come, "from forests or forestlands that are ecological communities with a global or State ranking of critically imperiled, imperiled, or rare pursuant to a State Natural Heritage Program, old growth forest, or late successional forest.". For the purposes of EISA, pre-commercial thinning is defined as, " those trees and other vegetative material removed from a stand of trees in order to reduce stocking to concentrate growth on more desirable trees". In order for the material to qualify as renewable biomass from "Areas at Risk From Wildfire", the forest land would need to be designated as part of the Wildland-Urban Interface as depicted and mapped by the electronic Wildland-Urban Interface map located at http://silvis.forest.wisc.edu/Library/WUILibrary.asp.

Forest residue qualifies as a renewable material and eligible for RINS, under both Section II.B.4.ii and Section II.B.4.iii, as both sections utilize the definition of "slash" as the presented in the Dictionary of Forestry. The definition states that slash is "the residue, e.g. treetops, and branches left on the ground after logging or accumulating as a result of a storm, fire, girdling or delimbing." For the plantation case the definition was expanded to the following for the final rule:" slash and any woody residue generated during the processing of planted trees from actively managed tree plantations for use in lumber, paper, furniture or other applications, 
providing that such woody residue is not mixed with similar residue from trees that do not originate in actively managed tree plantations."

Ultimately, the qualification of biomass as renewable is subject to verification that the feedstocks meet the requirements specified by EISA. Currently, there are three mechanisms that provide this verification. First, the individual fuel production facilities can perform their own recordkeeping and reporting. Second, renewable fuel producers can form a consortium that funds third-party audit of quality assurance, based on an EPA approved plan. The final method only is only available to producers sourcing their biomass entirely from within the United States. This method uses an aggregate compliance approach using USDA publicly available data about agricultural land to form the basis of determination on feedstock renewability. In the case of nonagricultural products, producers must obtain sufficient documentation from their suppliers to prove compliance with EISA definitions.

\section{SUSTAINABILITY CONSIDERATIONS}

Discussion of the sustainability of woody biomass was first presented in the 2015 woody SOT (Hartley et al. 2015). Potential risks to sustainability have not significantly changed since that time. The attractiveness of woody biomass as an energy source is still predicated on the material being both renewable and sustainable. Development of energy markets that utilize woody biomass will provide an incentive for forest landowners and forest managers to remove greater proportions of material from their forest through removal of forest residues and low value material, which generally have been left on site (Vance et al. 2014). Numerous potential benefits are associated with removal of biomass, including but not limited to removal of residual fuels, reducing the cost of site preparation and regeneration, and improving overall operability in the stand (Agee and Skinner 2005, Gan and Smith 2007, USDOE 2011, Skog and Barbour 2006). However, potential concerns are associated with an increased intensity of harvesting forest biomass, especially the impact on site productivity due to nutrient removal (Vance et al. 2014).

The basis for concern over nutrient removal is that the majority of the material removed as part of a biomass harvest contains most of the nutrient-rich material in the tree. By removing the tops and branches from the forest, nutrients that would have returned to the soil are removed, potentially leading to a decline in soil and overall stand productivity. While this is a reasonable train of thought, there is not a consensus among the forest science community about whether high-intensity harvest (i.e., removing the tops and branches) has a significant impact on long-term soil productivity. Ponder et al. (2012) reported that during the U.S. Department of Agriculture Forest Service's Long-Term Soil Productivity Study, which took place over 10 years at 45 sites across the United States, harvests that removed the nutrient-rich material had little effect on site productivity. One of the main reasons for a lack of significant and noticeable effect in soil productivity is due to operational constraints. For a typical biomass harvest, it is not practical to remove all available biomass due to both technological and economic constraints. Several studies on a variety of sites have found that operations are only able to economically collect between 20 and $75 \%$ of biomass in a stand (Nurmi 2007 , 
Ralevic et al. 2010, Klockow et al. 2013). Current technology and demand for biomass make it unlikely that removal will reach levels that will cause an impact on soil productivity. However, as technology advances and higher demands increase prices, it is possible that removals could reach levels that have a detrimental impact on forest soils.

Aside from nutrient removal, harvesting can cause soil compaction and/or displacement. During harvest, machines traversing the site compact the soil, changing the soil's physical structure by increasing soil strength and bulk density and reducing pore space (Fisher and Binkley 2000, Grigal 2000, Janowiak and Webster 2010). Soil compaction will occur anytime a machine passes over an area of ground; however, the severity may be increased during biomass harvest due to an increase in the machine passes required to collect the additional material (Burger 2002). However, if biomass harvest is performed in a similar manner to conventional timber harvest, it is unlikely that soil compaction will be significantly different, because the majority of the compaction happens during the first few machine passes (Janowiak and Webster 2010, Johnson et al. 2007).

While all negative site impacts associated with removal of biomass can be seen to diminish sustainability of the practice, it is possible to prevent or mitigate negative site impacts through implementation of proper strategies. Vance et al. (2014) propose that adhering to current best management practices, focusing functional values of interest, and monitoring nutrients will limit decreases in soil productivity as a result of biomass harvest. Best management practices remain the same, independent of the intensity of the harvest or material being harvested, and have been shown to be effective in protecting sustainability (Shepard 2006). Additionally, focusing functional values (such as growth rates or stream health) will place emphasis on the values of concern rather than a holistic ideal.

\section{SUMMARY}

The Terrestrial Feedstock Supply and Logistics Program within BETO focuses on (1) reducing the delivered cost of sustainably produced biomass, (2) preserving and improving the physical and chemical quality parameters of harvested biomass to meet the individual needs of biorefineries and other biomass users, and (3) expanding the quantity of feedstock materials accessible to the bioenergy industry. To support BETO and their bioenergy production goals, INL completes annual SOT reports for herbaceous and woody biomass feedstock logistics, which provides the status of technology development of feedstock logistics for biomass to biofuels given actual data and experimental results, relative to technical target and cost goals from design cases.

The 2018 Woody Feedstock SOT has been separated into three separate pathways that utilize woody feedstocks: indirect liquefaction, catalytic fast pyrolysis, and algal hydrothermal liquefaction. The 2018 delivered cost for the feedstocks were found to be $\$ 63.76 /$ dry ton, $\$ 87.82 /$ dry ton and $\$ 70.31 /$ dry ton, respectively (2016\$). In addition to the SOT analyses, projections for each pathway have been made for the year 2022. In 2022, the cost of feedstock for indirect liquefaction and algal hydrothermal liquefaction are estimated 
to remain constant over the period, while the feedstock for catalytic fast pyrolysis are estimated to be reduced to $\$ 70.31 /$ dry ton due to the replacement of $75 \%$ of the clean pine with less costly forest residues and the application of stepwise air classification and leaching of the lights fraction, which improves the quality of the forest residue to match or exceed the quality of clean pine.

For the IDL and AHTL pathways, the feedstock supply systems utilize what has been termed a conventional feedstock supply system. Conventional feedstock supply systems form the backbone of the emerging biofuels industry, but have limitations in their ability to adjust the quality of the material that they supply. To meet the demands of the CFP pathway, it will be required that the feedstock supply system shift from a conventional system to what has been termed "advanced" supply systems. Advanced systems incorporate innovative methods of material handling, processing and supply chain configuration. In advanced designs, variability of the feedstock can be reduce to produce feedstocks of a uniform format, moving toward biomass commoditization. The 2018 woody CFP case and the 2022 Projection both incorporate advanced concepts to increase access to biomass resources and diluting negative quality impacts.

\section{REFERENCES}

Abt, K. L., R. C. Abt, C. S. Galik and K. E. Skog. 2014. Effect of policies on pellet production and forests in the U.S. South: a technical document supporting the Forest Service update of the 2010 RPA Assessment. USFS. Asheville, NC, USA, US Department of Agriculture Forest Service, Southern Research Station. Gen. Tech. Rep. SRS-202: 33. Retrieved from http://www.srs.fs.usda.gov/pubs/gtr/gtr_srs202.pdf, [September 2, 2015].

Ackerman, P., B. Talbot, and B. Dahlin, 2014, "Biomass Harvesting and Logistics," In: T. Seifert (ed.), Bioenergy from Wood, Springer, Netherlands.

Agee, J. K. and C. N. Skinner, 2005, "Basic principles of forest fuel reduction treatments," Forest Ecology and Management 211(1): 83-96.

Argo, A. M., E. C. D. Tan, D. Inman, M. H. Langholtz, L. M. Eaton, J. J. Jacobson, C. T. Wright, D. J. Muth, M. M. Wu, Y.-W. Chiu, and R. L. Graham, 2013, "Investigation of biochemical biorefinery sizing and environmental sustainability impacts for conventional bale system and advanced uniform biomass logistics designs," Biofuels Bioprod. Bior. 7: 282-302

Argonne National Laboratory.2016 Summary of Expansions, Updates, and Results in GREET $^{\circledR} 2016$ Suite of Models. Technical Report, ANL/ESD16/21, https://greet.es.anl.gov.

Bals, B., C. Wedding, V. Balan, E. Sendich, and B. Dale, 2011, "Evaluating the impact of ammonia fiber expansion (AFEX) pretreatment conditions on the cost of ethanol production," Bioresource Technology 102(2): 1277-1283. 
B.D. Bals, C. Gunawan, J. Moore, F. Teymouri, B.E. Dale, 2013, Enzymatic hydrolysis of pelletized AFEX ${ }^{\mathrm{TM}}$-treated corn stover at high solid loadings, Biotechnol. Bioeng 111(2):264-271

Boavida, D., P. Abelha, I. Gulyurtlu, B. Valentim, and M. J. L. D. Sousa, 2012, “A study on coal blending for reducing NOx and N2O levels during fluidized bed combustion," Clean Air 5: 175-191.

Bonner, I., D. Muth, J. Koch, and D. Karlen, 2014, "Modeled impacts of cover crops and vegetative barriers on corn stover availability and soil quality," Bio Energy Res. 7: 576589.

Boardman, R. et al., 2013, Logistics, Costs, and GHG Impacts of Utility-Scale Cofiring with 20\% Biomass, Technical Report INL/EXT-12-25252, PNNL-22320.

Burger, J. A., 2002, "Soil and long-term site productivity values," In J. Richardson, R. Bjo"rheden, P. Hakkila, A. T. Lowe, and C. T. Smith (eds.) Bioenergy from sustainable forestry: Guiding principles and practice, Klewer Academic Publishers, Dordrecht.

Cafferty, K.G., Muth, D.J., Jacobson, J.J., Bryden, K.M, 2013a, Model Based Biomass System Design of Feedstock Supply Systems for Bioenergy Production. In: ASME 2013 International Design Engineering Technical Conferences and Computers and Information in Engineering Conference, August 4-7, Portland, OR, USA. ASME. pp. V02BT02A023.

Cafferty, K, J. Jacobson, and K. Kenney, 2013b, "Woody/Pyrolysis Feedstock 2013 State of Technology Report," Milestone Completion Report, Idaho National Laboratory.

Cafferty, K. G and D. S. Hartley, 2015, Woody Feedstock 2014 State of Technology Report, INL $\backslash L T D-15-34165$.

Cao, C.W. , D. Y. Yang \& Q. Liu, 2007, Research on Modeling and Simulation of Mixed Flow Grain Dryer, Drying Technology, 25:4, 681-687, DOI: 10.1080/07373930701290951

Carolan, J., S. Joshi, and B. E. Dale, 2007, "Technical and Financial Feasibility Analysis of Distributed Bioprocessing Using Regional Biomass Pre-Processing Centers," Journal of Agricultural \& Food Industrial Organization 5(2): 1203-1230.

Coyle, D. R., Coleman, M. D., Durant, J. A. and Newman, L. A., 2006, "Survival and growth of 31 Populus clones in South Carolina," Biomass and Bioenergy 30(8):750-758.

Dutta, A., M. Talmadge, J. Hensley, M. Worley, D. Dudgeon, D. Barton, P. Groenendijk, D. Ferrari, B. Stears, E. Searcy, C. Wright, and J. Hess, 2011, Process Design and Economics for Conversion of Lignocellulosic Biomass to Ethanol - Thermochemical Pathway by Indirect Gasification and Mixed Alcohol Synthesis, NREL/TP-5100-51400, May 2011.

EC-DG-ENV. 2015. Environmental Implications of Increased Reliance of the EU on Biomass from the South East US. B. Kittler, A. S. Olesen, W. Price, F. Aguilar and S. L. Bager. Brussels, Belgium, Pinchot Institute for Conservation \& COWI for the European 
Commission Directorate-General for Environment. ENV.B.1/ETU/2014/0043. Retrieved from http://www.aebiom.org/wp- content/uploads/2016/08/DG-ENVI-study-imports-fromUS-Final-report-July-2016.pdf.

Emerson, R., T. Westover, D. Carpenter, B. Evans, and D. Howe, 2014, “Thermochemical Conversion Feedstock Interface, Combined Milestone Completion Report: INL, NREL and PNNL," Idaho National Laboratory.

Erber, G., J. Routa, M. Kolstrom, C. Kanzian, L. Sikanen, and K. Stampfer, 2014, "Comparing Two Different Approaches in Modeling Small Diameter Energy Wood Drying in Logwood Piles," Croatian Journal of Forest Engineering 35: 15-22.

FAO 2016. FAOSTAT - Forestry Production and Trade. Rome, Italy, Food and Agriculture Organization of the United Nations. Retrieved from http://faostat3.fao.org/download/F/FO/E, [February 2016].

Fisher, R. F. and D. Binkley, 2000, Ecology and management of forest soils, John Wiley and Sons, Inc., New York.

Forest2Market 2015. Wood Supply Market Trends in the US South: 1995 - 2015. Charlotte, NC, USA, Forest2Market analysis for National Alliance of Forest Owners, US Endowment for Forestry and Communities, US Industrial Pellet Association. Retrieved from http://www.nafoalliance.org/ images/pellets/Forest2Market_USSouthWoodSupplyTrends.pdf [November 22, 2015].

FORISK, 2011, "Woody Biomass as a Forest Product - Wood Supply and Market Implications," B. Mendell, A. H. Lang, and T. Sydor, Forisk Consulting and National Alliance of Forest Owners, http://nafoalliance.org/wp-content/uploads/NAFO-US-WoodMarkets-Report-102411.pdf, accessed August 13, 2015.

Gan, J. and C. T. Smith, 2007, "Co-benefits of utilizing Forest residues for bioenergy production: The case for East Texas, USA," Biomass and Bioenergy 31(9): 623-630.

Graham, R., M. Langholtz, L. Eaton, J. Jacobson, C. Wright, M. Muth, D. Inman, E. Tan, M. $\mathrm{Wu}, \mathrm{Y}$. W. Chiu, S. Jones, L. Snowden-Swan, and A. Argo, 2013, "Investigation of Biochemical Biorefinery Sizing and Environmental Sustainability Impacts for Conventional Bale System and Advanced Uniform Biomass Logistics Designs," Biofuels, Bioproducts and BioPower.

Greene, W., J. Cutshall, C. Dukes, and S. Baker, 2014, "Improving Woody Biomass Feedstock Logistics by Reducing Ash and Moisture Content," Bioenergy Res 7(3): 816823.

Grigal, D. F., 2000, “Effects of extensive forest management on soil productivity," For. Ecol. Manag. 138(1-3): 167-185.

Hansen, J., J. Jacobson, and M. Roni, 2015, "Quantifying Supply Risk at a Cellulosic Biorefinery," In K. Chichakly and K. Saeed (eds.), Proceedings from the 33rd International Conference of the System Dynamics Society, Albany, New York: System Dynamics Society. 
Harris, R. A. and D. R. Phillips, 1986, "Density of Selected Wood Fuels," Georgia Forestry Commission, Georgia Forest Research Paper 61: 6.

Hartley, D., M. Roni, E. Searcy and P. Lamers. 2015. Woody/Pyrolysis Feedstock 2015 State of Technology Report, INL/LTD-15-36596, September 2015.

Hess, J. R., K. L. Kenney, L. P. Ovard, E. M. Searcy, and C. T. Wright, 2009, CommodityScale Production of an Infrastructure-Compatible Bulk Solid from Herbaceous Lignocellulosic Biomass. Uniform-Format Bioenergy Feedstock Supply System Design Report Series, INL/EXT-09-17527, April 2009.

Hill, L. D., 1990, Grain grades and standards: Historical issues shaping the future, Chicago, IL, USA, University of Illinois Press.

Hodges, D. G., A. J. Hartsell, C. Brandeis, T. J. Brandeis, and J. W. Bentley, 2012, "Recession Effects on the Forests and Forest Products Industries of the South," Forest Products Journal 61(8): 614-624.

Howe, D, T. Westover, D. Carpenter, D. Santosa, R. Emerson, S. Deutch, A. Starace, I. Kutnyakov, and Lukins, 2015, "Field-to-Fuel Performance Testing of Lignocellulosic Feedstocks: An Integrated Study of the Fast Pyrolysis-Hydrotreating Pathway," Energy and Fuels 29(5): 3188-3197.

Humbird, D., R. Davis, L. Tao, C. Kinchin, D. Hsu, A. Aden, P. Schoen, J. Lukas, B. Olthof, M. Worley, D. Sexton, and D. Dudgeon, 2011, Process Design and Economics for the Conversion of Lignocellulosic Biomass to Ethanol: Dilute-Acid Pretreatment and Enzymatic Hydrolysis of Corn Stover, NREL/TP-5100-47764, http://www.nrel.gov/biomass/pdfs/47764.pdf, accessed June 30, 2014.

IBSS, 2014, "Wood energy: understanding the forest connection," R. E. Bardon and D. W. Hazel, Southeastern Partnership for Integrated Biomass Supply Systems, http:/www.seibss.org/publications-and-patents/extension-and-outreach-publications/wood-energyunderstanding- the-forest-connection/at download/file, accessed August 13, 2015.

Jacobson, J., P. Lamers, M. Roni, K. Cafferty, K. Kenney, B. Heath, J. Hansen, and J. Tumuluru, 2014, Techno-economic analysis of a biomass depot, INL/EXT-14-33225, September 30, 2014.

Janowiak, M. K. and C. R. Webster, 2010, "Promoting Ecological Sustainability in Woody Biomass Harvesting," Journal of Forestry 108(1): 16-23.

Jernigan, M. O., 2012, "High tonnage harvesting and skidding for loblolly pine energy plantations," M.Sc. Thesis, Auburn University, Alabama

Johnson, L. R., D. Page-Dumroese, and H-S. Han, 2007, "Effects of machine traffic on the physical properties of ash cap soils," In D. Page-Dumroese, R. Miller, J. Mital, P. McDaniel, D. Miller (eds.) Proceedings of conference on Volcanic-ash-derived forest soils of the Inland Northwest: properties and implications for management and restoration, Proc. RMRS-P-44, Fort Collins, CO: U.S. Department of Agriculture, Forest Service, Rocky Mountain Research Station: 69-82. 
Jones, S, E. Tan, J. Jacobson, A. Meyer, A. Dutta, and L. Snowden-Swan, 2013, Process Design and Economics for the Conversion of Lignocellulosic Biomass to Hydrocarbon Fuels: Fast Pyrolysis and Hydrotreating Bio-oil Pathway, Pacific Northwest National Laboratory, DRAFT Technical Report to the Bioenergy Technologies Office.

Kaczmarek, D. J., D. R. Coyle, and M. D. Coleman, 2013, "Survival and growth of a range of Populus clones in central South Carolina USA through age ten: Do early assessments reflect longer-term survival and growth trends?," Biomass and Bioenergy 49: 260-272

Kenney, K. L., W. A. Smith, G. L. Gresham, and T. L. Westover, 2013, "Understanding biomass feedstock variability," Biofuels 4: 111-127.

Klockow, P. A., A. W. D’Amato, and J. B. Bradford, 2013, "Impacts of post-harvest slash and live-tree retention on biomass and nutrient stocks in Populus tremuloides Michx.dominated forests, northern Minnesota, USA," Forest Ecology and Management 291: 278-288.

Lacey, J. A., J. E. Aston, T. L. Westover, R. R. S. Cherry, and D. N. Thompson, 2015, "Removal of introduced inorganic content from chipped forest residues via air classification," Fuel 160: 265-273.

Lamers, P. and D. Hartley 2016. Domestic feedstock use patterns to identify market linkages. Idaho Falls, ID, USA, Idaho National Laboratory.

Lamers, P., M. S. Roni, J. S. Tumuluru, J. J. Jacobson, K. G. Cafferty, J. K. Hansen, K. Kenney, F. Teymouri, and B. Bals, 2015a, "Techno-economic analysis of decentralized biomass processing depots," Bioresource Technology 194: 205-213.

Langholtz, M, 2013, ORNL personal communication, December 2013.

Langholtz, M, 2014, ORNL personal communication, December 2014.

Lanning, D. N., J. H. Dooley, and C. J. Lanning, 2012, "Shear processing of wood chips into feedstock particles," in 2012 ASABE Annual International Meeting, Dallas, Texas, July 29-August 1, 2012, American Society of Agricultural and Biological Engineers.

Muth, D. J., M. H. Langholtz, E. C. D. Tan, J. J. Jacobson, A. Schwab, M. M. Wu, A. Argo, C. C. Brandt, K. G. Cafferty, Y. W. Chiu, A. Dutta, L. M. Eaton, and E. M. Searcy, 2014, "Investigation of thermochemical biorefinery sizing and environmental sustainability impacts for conventional supply system and distributed pre-processing supply system designs," Biofuels Bioprod. Bior 8: 545-567.

Nurmi, J., 2007, "Recovery of Forest residues for energy from spruce (Pices abies) dominated stands," Biomass and Bioenergy 31(6): 375-380.

Nurmi, J., 2014, "Changes in volumetric energy densities during storage of whole-tree feed stocks from silvicultural thinnings," Biomass and Bioenergy 61: 114-120.

Owens, V. N., D. L. Karlen, and J. A. Lacey et al. 2016. Regional Feedstock Partnership Report: Enabling the Billion-Ton Vision. U.S. Department of Energy and Idaho National Laboratory. INL/EXT-15-37477. 
Pace, D. P and N. A. Yancey, 2013, Biomass Feedstock PDU Project: Biomass Comminution Study, INL/EXT-14-31058.

Pearson, C.H., Halvorson, A.D., Moench, R.D. and Hammon, R.W., 2010. Production of hybrid poplar under short-term, intensive culture in Western Colorado. Industrial Crops and Products, 31(3), pp.492-498.

Ponder, F., R. L. Fleming, S. Berch, M. D. Busse, J. D. Elioff, P. W. Hazlett, and R. A. Voldseth, 2012, "Effects of organic matter removal, soil compaction and vegetation control on 10th year biomass and foliar nutrition: LTSP continent-wide comparisons," Forest Ecology and Management 278: 35-54.

Ralevic, P., M. Ryans, and D. Cormier, 2010, “Assessing forest biomass for bioenergy: operational challenges and cost considerations," The Forestry Chronicle 86(1): 43-50.

Reddy, D. V. and N. Krishna, 2009, "Precision animal nutrition: A tool for economic and eco-friendly animal production in ruminants," Livestock Research for Rural Development 21(3).

Roise, J. P., G. Catts, D. Hazel, A. Hobbs, and C. Hopkins, 2013, Balancing biomass harvesting and drying tactics with delivered payment practice, Technical Report-not held in TRLN member libraries, Greenville, SC: U.S. Endowment for Forestry and Community.

Sami, M., K. Annamalai, and M. Wooldridge, 2001, "Co-firing of coal and biomass fuel blends," Progress in Energy and Combustion Science 27(2): 171-214.

Searcy, E. and J. R. Hess, 2010, Uniform-Format Feedstock Supply System: A CommodityScale Design to Produce an Infrastructure-Compatible Biocrude from Lignocellulosic Biomass, INL/EXT-10-2037.

Searcy E. M, C. T. Wright, J. R. Hess, and T. Westover, 2012, "Logistics Costs for the 2012 Conventional Woody Biomass Feedstock Supply for Thermochemical Conversion," Idaho National Laboratory Technical Report to Office of Biomass Program, U.S. Department of Energy, January 2012.

Shepard, J. P., 2006, "Water quality protection in bioenergy production: the U.S. system of forestry Best Management Practices," Biomass and Bioenergy 30(4): 378-384.

Shih, J.-S. and H. C. Frey, 1995, "Coal blending optimization under uncertainty," European Journal of Operational Research 83(3): 452-465.

Skog, K. E. and R. J. Barbour, 2006, "Estimating woody biomass supply from thinning treatments to reduce fire hazard in the U.S. West," In P. L. Andrews and B. W. Butler (compilers), Conference proceedings RMRS-P-41-Fuels management: How to measure success, Ft. Collins, CO: USDA Forest Service Rocky Mountain Research Station: 657-672.

Sokhansanj, S., A. Turhollow, and E. Webb, 2014, Simulation of the DOE High-Tonnage Biomass Logistics Demonstration Projects-Auburn University, ORNL/TM-2014/505. 
Spinelli, R., Cavallo, E., Facello, A., Magagnotti, N., Nati, C. and Paletto, G., 2012. Performance and energy efficiency of alternative comminution principles: chipping versus grinding. Scandinavian Journal of Forest Research, 27(4), pp.393-400.

Stokes B., T. McDonald, and T. Kelly, 1993, Transpirational drying and costs for transporting woody biomass a preliminary review, Auburn, AL: USDA forest service, southern forest experiment station.

Thompson, J. and W. Sprinkle, 2013, Production, cost and chip characteristics of in-woods Microchipping. Council on Forest Engineering Annual Meeting, Auburn, AL (2013)

Thompson, V., J. Aston, J. Lacey and D. Thompson, 2016, Develop feedstock blends using combined chemical and mechanical separations along with formulation techniques to reduce feedstock costs and risks in the supply chain, 1.2.2.1 Milestone Completion Report.

Townsend, P. A., S. P. Kar, and R. O Miller, 2014, "Popular (Populus spp.) Trees for Biofuel Production," accessed 9-6-2016: http://articles.extension.org/pages/70456/poplar-populusspp-trees- for-biofuel-production.

Tumuluru, J.S., 2016, Specific energy consumption and quality of wood pellets produced using high-moisture lodgepole pine grind in a flat die pellet mill. Chemical Engineering Research and Design. 110(2016) 82-97.

U.S. Department of Energy, 2016a, 2016 Billion Ton Report: Advancing Domestic Resources for a Thriving Bioeconomy, Volume 1: Economic Availability of Feedstocks, M. H. Langholtz, B. J. Stokes, and L. M. Eaton (Leads), ORNL/TM-2016/160, Oak Ridge National Laboratory, Oak Ridge, TN: 448.

U.S. Department of Energy, 2016b, Bioenergy Technologies Office Multi-Year Program Plan, DOE/EE-1385, March 2016, http://www.energy.gov/sites/prod/files/2016/07/f33/mypp_march2016.pdf.

U.S. Department of Energy. 2011. U.S. Billion-Ton Update: Biomass Supply for a Bioenergy and Bioproducts Industry. R.D. Perlack and B.J. Stokes (Leads), ORNL/TM-2011/224. Oak Ridge National Laboratory, Oak Ridge, TN. 227p.

U.S. Department of Energy, Bioenergy Technologies Office, 2015, “Accomplishments and Successes," http://www.energy.gov/eere/bioenergy/accomplishments-andsuccesses\#2014, accessed July 2015.

U.S. Energy Information Administration, 2015a, "Electric Power Monthly: Table 5.6.A Average Retail Price of Electricity to Ultimate Customers by End-Use Sector," accessed 9/1/15: http://www.eia.gov/electricity/monthly/epm_table_grapher.cfm?t=epmt_5_6_a.

U.S. Energy Information Administration, 2015b, “Gasoline and Diesel Fuel Update," accessed 9/1/15: http://www.eia.gov/petroleum/gasdiesel/.

U.S. Energy Information Administration, 2015c, "Natural Gas: Henry Hub Natural Gas Spot Price-Annual History,” accessed 9/1/15: http://www.eia.gov/dnav/ng/hist/rngwhhdA.htm. 
U.S Energy Information Administration, 2013, Manufacturing Energy Consumption Survey (MECS). Washington DC, USA, US Energy Information Administration (EIA). Retrieved from https://www.eia.gov/consumption/manufacturing/, accessed February 2016.

U.S. Forest Service, 2012, Future of America's Forest and Rangelands: Forest Service 2010 Resources Planning Act Assessment. Washington, DC, USA, United States Forest Service. Retrieved from http://www.treesearch.fs.fed.us/pubs/41976/, accessed February 2016.

Vakkilainen, E., K, Kuparinen and J. Heinimö, 2013, Large Indusrial Users of Energy Biomass. IEA Bioenergy, Task 40: Sustainable International Bioenergy Trade. pp 75.

Vance, E. D., W. M. Aust, B. D. Strahm, R. E. Froese, R. B. Harrison, and L. A. Morris, 2014, "Biomass Harvesting and Soil Productivity: Is the Science Meeting our Policy Needs?," Soil Science Society of America Journal 78(S1): S95-S104.

Wang, J., D. S. Hartley, and W. Liu, 2013, "Biomass Harvesting Systems and Analysis," In: M. Jacobson and D. Ciolkosz (eds.), Wood Based Energy in the Northern Forests: 101120, New York: Springer.

Webb, E., S. Sokhansanj, and A. Turhollow, 2013a, Simulation of the DOE High-Tonnage Biomass Logistics Demonstration Projects-AGCO Corporation ORNL/TM-2013/323.

Webb, E., S. Sokhansanj, and A. Turhollow, 2013b, Simulation of the DOE High-Tonnage Biomass Logistics Demonstration Projects-FDC Enterprises, ORNL/TM-2013/338.

Webb, E., S. Sokhansanj, and A. Turhollow, 2013c, Simulation of the DOE High-Tonnage Biomass Logistics Demonstration Projects-State University of New York College of Environmental Science and Forestry ORNL/TM-2013/376.

Webb, E., S. Sokhansanj, and A. Turhollow, 2013d, Simulation of the DOE High-Tonnage Biomass Logistics Demonstration Projects-TennEra LLC, ORNL/TM-2013/375.

Wright, J., 2013, “Advances in Hardwood Plantation Systems Implications for Bio-energy feedstock," In: 2013 SWST International Convention, Austin, TX. June 9-11, 2013.

Yancey, N. A., C.T. Wright, C.C. Connor and J.R. Hess, 2009, "Preprocessing moist lignocellulosic biomass for biorefinery feedstocks," Proceedings of the ASABE Annual Meeting, Reno, Nevada. 


\section{APPENDIX A - 2018 Woody State of Technology Feedstocks Logistics Design and Assumptions for Forest Residue Supply to IDL}

The 2018 woody SOT (Figure A-1) case for IDL consists of $100 \%$ forest residue, and supplies 7500,000 dry tons of biomass annually to the throat of the conversion reactor. The forest residues are preprocessed at the roadside using a system that is based on the chip processing system that was studied by Auburn University during their High Tonnage Logistics Demonstration Project. The processed forest residues are transported from their aggregation points after preprocessing. The materials are delivered directly to the biorefinery, where they are dried using process heat before being delivered to the throat of the reactor.

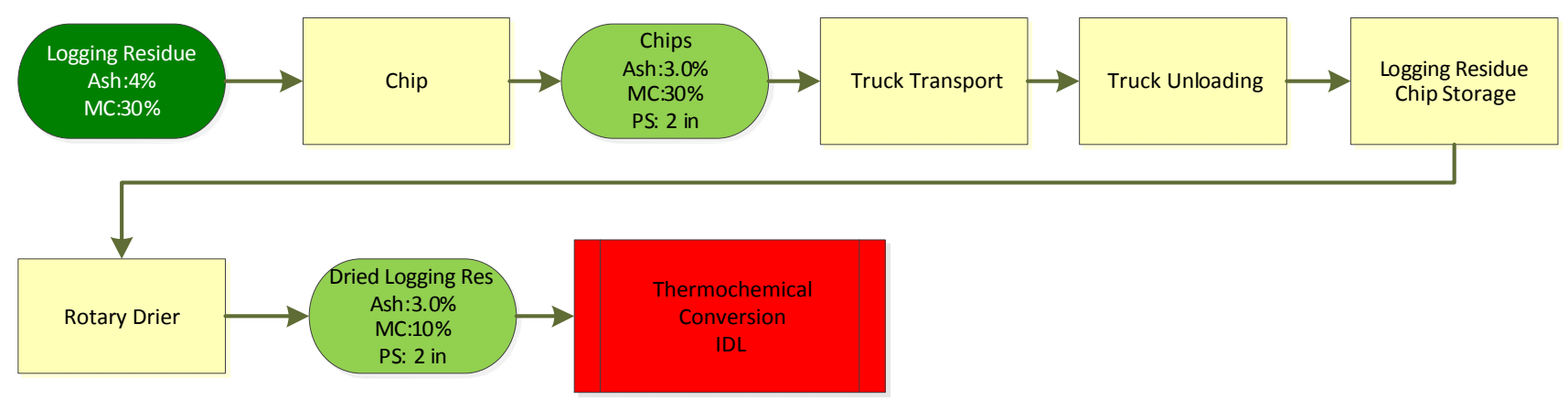

Figure A-1. 2018 woody SOT feedstock supply system design supporting thermochemical conversion.

The model relies on assumptions about exogenous factors such as interest rates, energy prices, and land rents. The prices for electricity, natural gas, and off-road diesel were updated to more accurately reflect market conditions. Table A-1 shows the values of the assumptions used.

Table A-1 Updated energy prices and interest rates used to model feedstock logistics costs for the 2018 woody SOT.

\begin{tabular}{|l|c|c|}
\multicolumn{1}{|c|}{ Component } & $\mathbf{2 0 1 7}$ Assumptions & $\mathbf{2 0 1 8}$ Assumptions \\
\hline Interest Rate & $8 \% \mathrm{a}$ & $8 \% \mathrm{a}$ \\
\hline Electricity Price & $\$ 0.0672 / \mathrm{kWh}$ & $\$ 0.0672 / \mathrm{kWh}$ \\
\hline Natural Gas Price & $\$ 3.36 / \mathrm{MMBtub}$ & $\$ 3.36 / \mathrm{MMBtub}$ \\
\hline Off-Road Diesel Price & $\$ 2.01 /$ gald $_{\mathrm{b}}$ & $\$ 2.01 /$ gald \\
\hline
\end{tabular}

aJones et al. 2013.

bEIA 2017 


\section{A.1 Grower Payment}

Grower payment ${ }^{1}$ represents the stumpage price paid to the landowner to secure permission to harvest the material. The grower payment was calculated using the size class stumpage values reported in the 2016 Billion Ton Report (57\% Size Class 1, 43\% Size Class 2; BT16; USDOE, 2016) and the residue ratios from the USDA Forest Service Forest Inventory and Analysis Database (15\% for Size Class 1, 14\% for size Class 2; USDA Forest Service, 2017). BT16 provides values of $\$ 32 /$ dry ton, $\$ 16 /$ dry ton and $\$ 8 /$ dry ton, for both planted and natural softwood stands, of size classes 1, 2 and 3, respectively in the Southern Region. Based on the assumed harvest region, the size class distribution of delivered material and residue ratio, leads to a weighted average grower payment of $\$ 3.70 /$ dry ton.

\section{A.2 Harvest and Collection}

The 2018 woody SOT for IDL utilizes only forest residues. Forest residues are materials, in the form of limbs, tops, cutoffs, and/or culled material that originate from the harvest of saw $\log$ material. This material is accumulated at the landing as saw logs are processed and stored in piles. Because the material is a byproduct of saw log processing, the cost of harvest and collection are not attributed to the material.

\section{A.3 Storage}

Storage involves stockpiling material to provide an adequate lead time for downstream processes and accumulating material quantities for economical transportation. Woody biomass is subject to degradation by fungi, yeast, and bacteria that alter the feedstock's composition. Degradation is a more prevalent problem in comminuted biomass, which has a higher surface area exposed and accessible to the damaging agents. Conversely, if the woody biomass is stored as uncomminuted material, the material is stable and can be kept for periods greater than a year without experiencing a reduction in quality (Nurmi 2014, Erber et al. 2014, and Ackerman et al. 2014). The additional benefit of storage in the field is that the material dries during that time, reducing the moisture content before transportation (Stokes et al. 1993).

Field drying during storage (first included in the 2014 woody SOT and is also a key component of Auburn's High Tonnage Logistics Demonstration Project (Cafferty and Hartley 2015, Sokhansanj et al. 2014) is included in the 2018 woody SOT for IDL. A variety of data shows the effectiveness of field drying, which is highly variable by region, species, age, and methodology. A study conducted by North Carolina State University has showed that by allowing logs to dry on the landing for a period of 330 to 360 days, the moisture content can be reduced from $50 \%$ to approximately $18 \%$, independent of time of harvest or tree type (i.e., hardwood or softwood) (Roise et al. 2013). Because the study was completed in the same region as the defined study area, we can assume that similar results are likely and an assumption of a moisture reduction of $20 \%$ (from $50 \%$ down to $30 \%$ ) in both clean pine and forest residue is conservative. Similar studies in other areas have shown greater moisture reductions in less time (Stokes et al. 1993, Greene et al. 2014).

\footnotetext{
${ }^{1}$ Grower payment is the road-side selling price, less any preprocessing costs that are incurred.
} 
When the materials reach the refinery they are stored in uncovered piles to await drying. The storage requirements at the conversion facility are assumed to be enough material to sustain the operation for 1 week of operation. This quantity of material is assumed to be adequate to sustain operations during periods of time when material is not supplied due to weather or other disruptions, while also not being so great that storage losses will be large due to degradation (Table A-2).

Table A-2. Key storage assumptions for the 2018 woody SOT for IDL.

\begin{tabular}{|l|c|}
\hline \multicolumn{1}{|c|}{ Component } & Forest Res. \\
\hline Fieldside & Uncovered pile \\
\hline Gype & None \\
\hline Material Loss (\%) & $<1 \%$ \\
\hline Biorefinery & \\
\hline Type & Uncovered pile \\
\hline Ground Cover & Asphalt pad \\
\hline Material Loss (\%) & $2 \%$ \\
\hline Days of Supply & 6 \\
\hline
\end{tabular}

\section{A.4 Landing Preprocessing}

The landing is the location where forest materials are initially aggregated, stored, and processed for transport and sale after harvest. Landing preprocessing is used to improve the transportation and handling characteristics of the biomass feedstocks. Landing processing is designed to increase the bulk density and/or remove materials that will be considered waste further along the supply chain. Through both increasing density and removing waste materials, transportation cost for the material is reduced and subsequent processing is made more efficient.

Landing preprocessing for the forest residues included in the 2018 woody SOT for IDL blend begins before transportation to the depot. In this design the only preprocessing at the landing is chipping. The forest residues are chipped to a 2-in. chip using a mobile disk chipper. Production and fuel consumption for the chipper were taken from the DOE HighTonnage Biomass Logistics Demonstration Project that was carried out by Auburn University. This project looked at both chipping tree length material and the effect of field drying on chipping operations. The chips are then loaded into the chip trailer by the loader blowing the chips from the out feed (Table A-3).

Forest residue is processed at the landing in much the same way as clean pine by first going through a flail debarker and then chipped using a disk chipper. It was assumed that the throughput for the chipper would be the same as for clean pine operation, but the cleanup operation would be less effective with the processed forest residue having approximately 
$1.25 \%$ compared to the $0.5 \%$ ash in the clean pine. Additionally, attempting to clean-up forest residues is assumed to result in a $40 \%$ material loss. The chips are also loaded into the chip trailers by blowing the chips from the outfeed of the chipper (Table A-3).

Table A-3. Key landing preprocessing assumptions for the 2018 woody SOT for IDL.

\begin{tabular}{|l|c|}
\hline \multicolumn{1}{|c|}{ Component } & Forest Res. \\
\hline Type & Knuckle boom \\
\hline Capacity (ton/hr) & 75.6 \\
\hline Size Reduction & \\
\hline Type & Chipper \\
\hline Capacity (ton/hour) & 79.8 \\
\hline Dry Matter Loss (\%) & 5 \\
\hline Particle Size & 2 in. \\
\hline Moisture Content & $30 \%$ \\
\hline
\end{tabular}

\section{A.5 Transportation and Handling}

Transportation includes all processes involved in movement of material to a centralized location (such as a preprocessing facility or to the biorefinery). Transportation includes processes such as loading, trucking, rail transport, and unloading. Beyond transportation, additional handling is required to transfer and queue biomass to the conversion facility. Surge bins, conveyors, dust collection, and miscellaneous equipment are used in handling operations. Handling operations depend on many factors, including biomass moisture content, bulk density, and particle size and shape distribution. Lignocellulosic feedstock inherently possesses characteristics that inhibit handling (e.g., high cohesivity, low density, high compressibility, and high variability in particle size and shape uniformity) (Kenney et al. 2013). For this reason, lignocellulosic feedstock handling operations are typically designed at $150 \%$ of design capacity in order to accommodate variability in biomass handling properties.

The 2018 woody SOT for IDL uses truck transportation to the depot/biorefinery (Table A4). The forest residues are blown from the chipper into possum belly open back trailers with a capacity of 4,000 $\mathrm{ft}_{3}$. The material is assumed to have a dry bulk density of $11 \mathrm{lb} / \mathrm{ft}_{3}$ (Harris and Phillips 1986) and the assumed moisture content at transportation is $30 \%$ (wet basis) (Greene et al, 2014). This resulted in a calculated weight-limited payload of $17.68 \mathrm{dry}$ ton/load for the forest residue material. The draw radius for the forest residue was 88 miles, based on material availability.

Table A-4. Key transportation and handling assumptions for the 2018 woody SOT for IDL. 


\begin{tabular}{|l|l|}
\hline Component & Forest Residue \\
\hline Truck & \\
\hline Type & Day Cab \\
\hline Transportation Distance (mi) & 88 \\
\hline Speed (mph) & 50 \\
\hline Trailer & \\
\hline Type & Open back possum belly \\
\hline Volume & $4,000 \mathrm{ft}^{3}$ \\
\hline Dry Bulk Density & $11 \mathrm{lb} / \mathrm{ft}^{3}$ \\
\hline Moisture Content & $30 \%$ \\
\hline
\end{tabular}

\section{A.6 Handling, Refinery Operations}

The materials are offloaded at the facility using a truck tipper with a hopper, where they are transported to storage by a conveyor. Depot operations include processing operations required to create a uniform feedstock for distribution and use in the conversion process. In addition to processing of the feedstock, depot operations may also include necessary auxiliary operations (such as dust collection and conveyor) to move material from one operation to the next.

The 2018 woody SOT for IDL refinery operations include only drying using process heat (Table A-5). The material is dried to $10 \%$ moisture content (wet basis) in a rotary drier using excess process heat from gasification. After drying, the forest residues are placed in queue for feeding to the reactor.

Table A-5. Assumptions of key depot operations in the 2018 woody SOT for IDL.

\begin{tabular}{|l|l|}
\hline Component & Forest Residue \\
\hline Loader & $120 \mathrm{ton} / \mathrm{hr}$ \\
\hline Capacity & \\
\hline Dryer & $1.5 \mathrm{ton} / \mathrm{hr}$ \\
\hline Capacity & $38.78 \mathrm{kWh} / \mathrm{ton}$ \\
\hline Energy Consumption & $178.57 \mathrm{MMBtu} / \mathrm{hr}$ \\
\hline Waste Heat & $20 \%$ \\
\hline Moisture Reduction & \\
\hline
\end{tabular}




\section{APPENDIX B - 2022 Projection for Woody Feedstock Logistics Design and Assumptions for Forest Residue Supply to IDL}

The 2022 woody design case for IDL (Figure B-1) consists of 100\% forest residue, and supplies 725,000 dry tons of biomass annually to the throat of the conversion reactor. The forest residues are preprocessed at the roadside using a system that is based on the chip processing system that was studied by Auburn University during their High Tonnage Logistics Demonstration Project. The processed forest residues are transported from their aggregation points after preprocessing. The materials are delivered directly to the biorefinery, where they are dried using process heat before being delivered to the throat of the reactor.

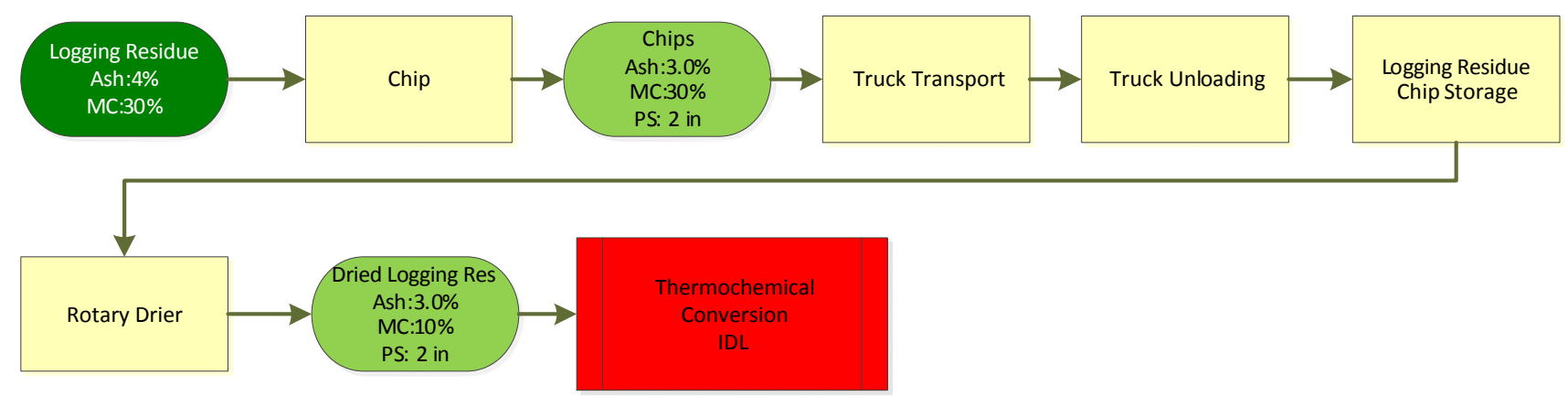

Figure B-1. 2022 woody feedstock supply system design supporting IDL conversion.

The model relies on assumptions about exogenous factors such as interest rates, energy prices, and land rents. The prices for electricity, natural gas, and off-road diesel were updated to more accurately reflect market conditions. Table B-1 shows the updates of these assumptions compared to the assumptions used in 2016.

Table B-1 Updated energy prices and interest rates used to model feedstock logistics costs for the 2022 woody design for IDL.

\begin{tabular}{|l|c|c|}
\multicolumn{1}{|c|}{ Component } & $\mathbf{2 0 1 8}$ Assumptions & 2022 Assumptions \\
\hline Interest Rate & $8 \% \mathrm{a}$ & $8 \% \mathrm{a}$ \\
\hline Electricity Price & $\$ 0.0672 / \mathrm{kWh} \mathrm{b}$ & $\$ 0.0672 / \mathrm{kWhb}$ \\
\hline Natural Gas Price & $\$ 3.36 / \mathrm{MMBtub}$ & $\$ 3.36 / \mathrm{MMBtub}$ \\
\hline Off-Road Diesel Price & $\$ 2.01 / \mathrm{gal}_{\mathrm{d}}$ & $\$ 2.01 / \mathrm{gald}_{\mathrm{d}}$ \\
\hline
\end{tabular}

aJones et al. 2013.

bEIA 2017 


\section{A.7 Grower Payment}

Grower payment ${ }^{2}$ represents the stumpage price paid to the landowner to secure permission to harvest the material. The grower payment was calculated using the size class stumpage values reported in the 2016 Billion Ton Report (57\% Size Class 1, 43\% Size Class 2; BT16; USDOE, 2016) and the residue ratios from the USDA Forest Service Forest Inventory and Analysis Database (15\% for Size Class 1, 14\% for size Class 2; USDA Forest Service, 2017). BT16 provides values of $\$ 32 /$ dry ton, $\$ 16 /$ dry ton and $\$ 8 /$ dry ton, for both planted and natural softwood stands, of size classes 1, 2 and 3, respectively in the Southern Region. Based on the assumed harvest region, the size class distribution of delivered material and residue ratio, leads to a weighted average grower payment of $\$ 3.70 /$ dry ton.

\section{A.8 Harvest and Collection}

The 2018 woody SOT for IDL utilizes only forest residues. Forest residues are materials, in the form of limbs, tops, cutoffs, and/or culled material that originate from the harvest of saw log material. This material is accumulated at the landing as saw logs are processed and stored in piles. Because the material is a byproduct of saw log processing, the cost of harvest and collection are not attributed to the material.

\section{A.9 Storage}

Storage involves stockpiling material to provide an adequate lead time for downstream processes and accumulating material quantities for economical transportation. Woody biomass is subject to degradation by fungi, yeast, and bacteria that alter the feedstock's composition. Degradation is a more prevalent problem in comminuted biomass, which has a higher surface area exposed and accessible to the damaging agents. Conversely, if the woody biomass is stored as uncomminuted material, the material is stable and can be kept for periods greater than a year without experiencing a reduction in quality (Nurmi 2014, Erber et al. 2014, and Ackerman et al. 2014). The additional benefit of storage in the field is that the material dries during that time, reducing the moisture content before transportation (Stokes et al. 1993).

Field drying during storage (first included in the 2014 woody SOT and is also a key component of Auburn's High Tonnage Logistics Demonstration Project (Cafferty and Hartley 2015, Sokhansanj et al. 2014) is included in the 2022 woody design for IDL. A variety of data shows the effectiveness of field drying, which is highly variable by region, species, age, and methodology. A study conducted by North Carolina State University has showed that by allowing logs to dry on the landing for a period of 330 to 360 days, the moisture content can be reduced from $50 \%$ to approximately $18 \%$, independent of time of harvest or tree type (i.e., hardwood or softwood) (Roise et al. 2013). Because the study was completed in the same region as the defined study area, we can assume that similar results are likely and an assumption of a moisture reduction of $20 \%$ (from $50 \%$ down to $30 \%$ ) in both clean pine and forest residue is conservative. Similar studies in other areas have shown greater moisture reductions in less time (Stokes et al. 1993, Greene et al. 2014).

\footnotetext{
${ }^{2}$ Grower payment is the road-side selling price, less any preprocessing costs that are incurred.
} 
When the materials reach the refinery they are stored in uncovered piles to await drying. The storage requirements at the conversion facility are assumed to be enough material to sustain the operation for 1 week of operation. This quantity of material is assumed to be adequate to sustain operations during periods of time when material is not supplied due to weather or other disruptions, while also not being so great that storage losses will be large due to degradation (Table B-2).

Table B-2 Key storage assumptions for the 2018 woody design for IDL.

\begin{tabular}{|l|c|}
\hline \multicolumn{1}{|c|}{ Component } & Forest Res. \\
\hline Fieldside & Uncovered pile \\
\hline Type & None \\
\hline Ground Cover & $<1 \%$ \\
\hline Material Loss (\%) & \\
\hline Biorefinery & Uncovered pile \\
\hline Type & Asphalt pad \\
\hline Ground Cover & $2 \%$ \\
\hline Material Loss (\%) & 6 \\
\hline Days of Supply & \\
\hline
\end{tabular}

\section{A.10 Landing Preprocessing}

The landing is the location where forest materials are initially aggregated, stored, and processed for transport and sale after harvest. Landing preprocessing is used to improve the transportation and handling characteristics of the biomass feedstocks. Landing processing is designed to increase the bulk density and/or remove materials that will be considered waste further along the supply chain. Through both increasing density and removing waste materials, transportation cost for the material is reduced and subsequent processing is made more efficient.

Landing preprocessing for the forest residues included in the 2022 woody design for IDL blend begins before transportation to the depot. In this design the only preprocessing at the landing is chipping. The forest residues are chipped to a 2-in. chip using a mobile disk chipper. Production and fuel consumption for the chipper were taken from the DOE HighTonnage Biomass Logistics Demonstration Project that was carried out by Auburn University. This project looked at both chipping tree length material and the effect of field drying on chipping operations. The chips are then loaded into the chip trailer by the loader feeding the chipper and blowing the chips from the out feed (Table B-3).

Forest residue is processed at the landing in much the same way as clean pine by first going through a flail debarker and then chipped using a disk chipper. It was assumed that the throughput for the chipper would be the same as for clean pine operation, but the cleanup operation would be less effective with the processed forest residue having approximately $1.25 \%$ compared to the $0.5 \%$ ash in the clean pine. Additionally, attempting to clean-up forest 


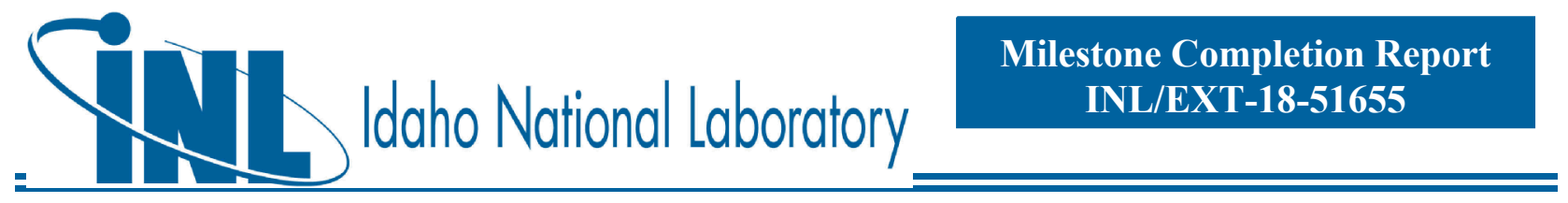

residues is assumed to result in a $40 \%$ material loss. The chips are also loaded into the chip trailers by blowing the chips from the outfeed of the chipper (Table B-3).

Table B-3 Key landing preprocessing assumptions for the 2022woody design for IDL.

\begin{tabular}{|l|c|}
\hline \multicolumn{1}{|c|}{ Component } & Forest Res. \\
\hline Type & Knuckle boom \\
\hline Capacity (ton/hr) & 75.6 \\
\hline Size Reduction & \\
\hline Type & Chipper \\
\hline Capacity (ton/hour) & 79.8 \\
\hline Dry Matter Loss $(\%)$ & 5 \\
\hline Particle Size & 2 in. \\
\hline Moisture Content & $30 \%$ \\
\hline
\end{tabular}

\section{A.11 Transportation and Handling}

Transportation includes all processes involved in movement of material to a centralized location (such as a preprocessing facility or to the biorefinery). Transportation includes processes such as loading, trucking, rail transport, and unloading. Beyond transportation, additional handling is required to transfer and queue biomass to the conversion facility. Surge bins, conveyors, dust collection, and miscellaneous equipment are used in handling operations. Handling operations depend on many factors, including biomass moisture content, bulk density, and particle size and shape distribution. Lignocellulosic feedstock inherently possesses characteristics that inhibit handling (e.g., high cohesivity, low density, high compressibility, and high variability in particle size and shape uniformity) (Kenney et al. 2013). For this reason, lignocellulosic feedstock handling operations are typically designed at $150 \%$ of design capacity in order to accommodate variability in biomass handling properties.

The 2018 woody design for IDL uses truck transportation to the depot/biorefinery (Table B-4). The forest residues are blown from the chipper into possum belly open back trailers with a capacity of $4,000 \mathrm{ft}$. The material is assumed to have a dry bulk density of $11 \mathrm{lb} / \mathrm{ft}_{3}$ (Harris and Phillips 1986) and the assumed moisture content at transportation is $30 \%$ (wet basis) (Greene et al, 2014). This resulted in a calculated weight-limited payload of 17.68 dry ton/load for the forest residue material. The draw radius for the forest residue was 88 miles, based on material availability. 
Table B-4. Key transportation and handling assumptions for the 2022 woody design for IDL.

\begin{tabular}{|l|l|} 
Component & Forest Residue \\
\hline Type & Day Cab \\
\hline Transportation Distance (mi) & 88 \\
\hline Speed (mph) & 50 \\
\hline Trailer & \\
\hline Type & Open back possum belly \\
\hline Volume & $4,000 \mathrm{ft}^{3}$ \\
\hline Dry Bulk Density & $11 \mathrm{lb} / \mathrm{ft}^{3}$ \\
\hline Moisture Content & $30 \%$ \\
\hline
\end{tabular}

\section{A.12 Handling, Refinery Operations}

The materials are offloaded at the facility using a truck tipper with a hopper, where they are transported to storage by a conveyor. Depot operations include processing operations required to create a uniform feedstock for distribution and use in the conversion process. In addition to processing of the feedstock, depot operations may also include necessary auxiliary operations (such as dust collection and conveyor) to move material from one operation to the next.

The 2017 woody SOT refinery operations include only drying using process heat (Table B5). The material is dried to $10 \%$ moisture content (wet basis) in a rotary drier using excess process heat from gasification. After drying, the forest residues are placed in queue for feeding to the reactor.

Table B-5. Assumptions of key depot operations for the 2022 woody design for IDL.

\begin{tabular}{|l|l|}
\hline $\begin{array}{l}\text { Component } \\
\text { Loader }\end{array}$ & \multicolumn{1}{l|}{ Forest Residue } \\
\hline Capacity & $120 \mathrm{ton} / \mathrm{hr}$ \\
\hline Drver & \\
\hline Capacity & $1.5 \mathrm{ton} / \mathrm{hr}$ \\
\hline Energy & $38.78 \mathrm{kWh} / \mathrm{ton}$ \\
\hline Waste Heat & $178.57 \mathrm{MMBtu} / \mathrm{hr}$ \\
\hline
\end{tabular}




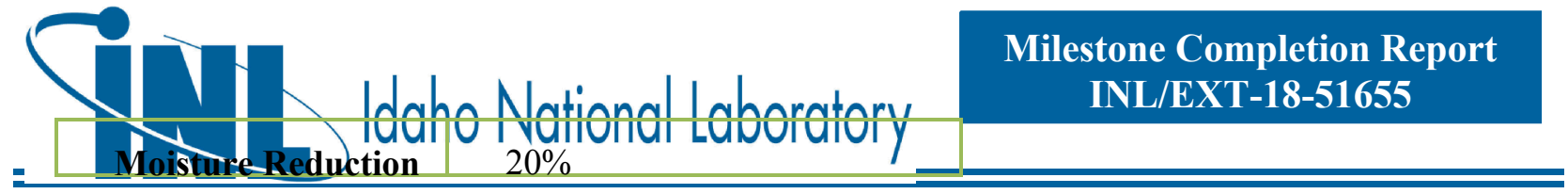




\section{APPENDIX C - 2018 Woody State of Technology Feedstock Logistics Design and Assumptions for Clean Pine Supply to CFP}

The 2018 woody SOT for CFP (Figure C-1) consists of $100 \%$ clean pine which supplies 725,000 dry tons of biomass annually to the throat of the conversion reactor. Clean pine is harvested and preprocessed using a modified ground-based mechanized chip production system that is based on the system that was studied by Auburn University during their High Tonnage Logistics Demonstration Project. All materials are transported to a processing facility. During preprocessing, the materials are processed into pellets before being blended to create a feedstock of uniform quality for use in the biorefinery.

The model relies on assumptions about exogenous factors such as interest rates, energy prices, and land rents. The prices for electricity, natural gas, and off-road diesel were updated to more accurately reflect market conditions. Table $\mathrm{C}-1$ shows the updates that were used.

Table C-1 Updated energy prices and interest rates used to model feedstock logistics costs for the 2018 woody SOT for CFP

\begin{tabular}{|l|c|c|}
\multicolumn{1}{|c|}{ Component } & $\mathbf{2 0 1 7}$ Assumptions & $\mathbf{2 0 1 8}$ Assumptions \\
\hline Interest Rate & $8 \% \mathrm{a}$ & $8 \% \mathrm{a}$ \\
\hline Electricity Price & $\$ 0.0672 / \mathrm{kWh}$ & $\$ 0.0672 / \mathrm{kWh}$ \\
\hline Natural Gas Price & $\$ 3.36 / \mathrm{MMBtub}$ & $\$ 3.36 / \mathrm{MMBtub}$ \\
\hline Off-Road Diesel Price & $\$ 2.01 /$ gald & $\$ 2.01 /$ gald \\
\hline
\end{tabular}

aJones et al. 2013.

bEIA 2017

\section{A.13 Grower Payment}

Grower payment represents the stumpage price paid to the landowner to secure permission to harvest the material. The grower payment was calculated using the size class stumpage values reported in the 2016 Billion Ton Report (BT16; USDOE, 2016) and. BT16 provides values of $\$ 32 /$ dry ton, $\$ 16 /$ dry ton and $\$ 8 /$ dry ton, for both planted and natural softwood stands, of size classes 1, 2 and 3, respectively in the Southern Region. Based on the assumed harvest region, the size class distribution of delivered material was $83 \%$ from size class 3 and $17 \%$ from size class 2 ; the resulting weighted average grower payment for clean pine is then calculated as $\$ 9.36 /$ dry ton.

\section{A.14 Harvest and Collection}

The harvest of clean pine for energy is similar to harvest of materials for the production of paper or lumber, using integrated activities to prepare the raw material for transport from the 

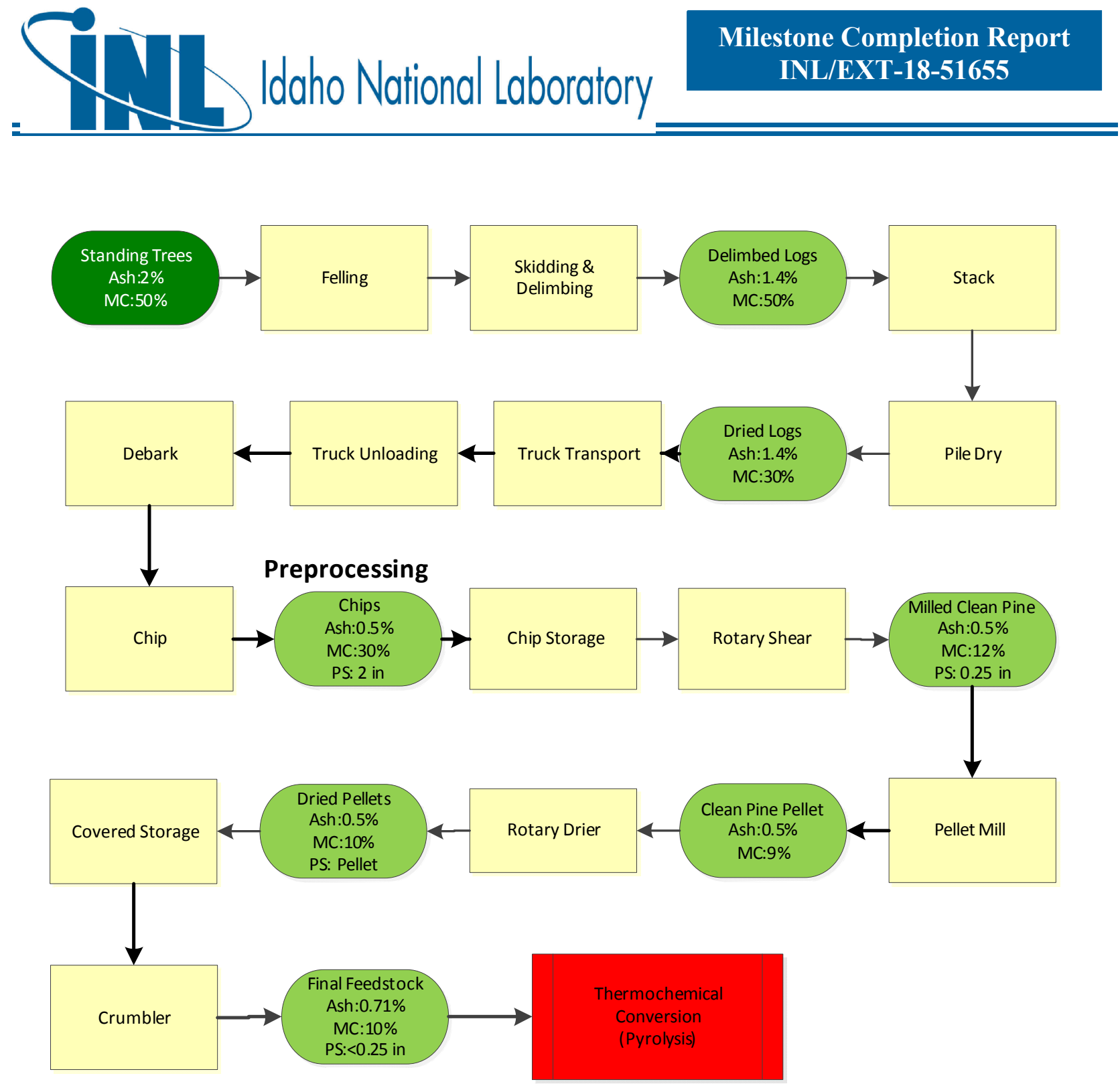

Figure C-1. 2018 woody SOT feedstock supply system design supporting thermochemical conversion.

field to the processing facility (Wang et al. 2013). The 2018 woody SOT for CFP maintains the same type of system for clean pine harvest and collection that had been used previously and is based on the system studied in the DOE High-Tonnage Biomass Logistics Demonstration Project carried out by Auburn University. The system uses a tracked feller buncher with a high speed shear for felling the clean pine-sized material. Collection and primary transportation is completed using a grapple skidder with an oversized grapple to increase payload. Felling production using the feller buncher is 49 dry tons per hour. (Cafferty and Hartley 2015, Sokhansanj et al. 2014, Jernigan 2012). Collection of the material is completed through use of a grapple skidder with a capacity of 40 dry tons per hour (Cafferty and Hartley 2015, Sokhansanj et al. 2014, Jernigan 2012). 
Table C-2. Key harvest and collection assumptions for the 2018 woody SOT for CFP.

\begin{tabular}{|c|c|}
\hline Component & Clean Pine \\
\hline \multicolumn{2}{|l|}{ Harvest Machine } \\
\hline Type & Feller-buncher \\
\hline Rated Capacity (ton/hour) & 75.38 \\
\hline Utilization (\%) & 65 \\
\hline \multicolumn{2}{|l|}{ Collection Machine } \\
\hline Type & Grapple skidder \\
\hline Rated Capacity (ton/hour) & 62 \\
\hline Utilization (\%) & 65 \\
\hline Average Extraction Distance (feet) & 1,500 \\
\hline Initial Moisture Content & $50 \%$ \\
\hline Field Dry Moisture Content & $30 \%$ \\
\hline Operation Hours & $\begin{array}{c}50 \text { week/year, } \\
5 \text { day/week, } \\
8 \text { hour/day }\end{array}$ \\
\hline
\end{tabular}

\section{A.15 Storage}

Storage involves stockpiling material to provide an adequate lead time for downstream processes and accumulating material quantities for economical transportation. Woody biomass is subject to degradation by fungi, yeast, and bacteria that alter the feedstock's composition. Degradation is a more prevalent problem in comminuted biomass, which has a higher surface area exposed and accessible to the damaging agents. Conversely, if the woody biomass is stored as uncomminuted material, the material is stable and can be kept for periods greater than a year without experiencing a reduction in quality (Nurmi 2014, Erber et al. 2014, Ackerman et al. 2014). The additional benefit of storage in the field is that the material dries during that time, reducing the moisture content before transportation (Stokes et al. 1993).

Field drying during storage (first included in the 2014 woody SOT and is also a key component of Auburn's High Tonnage Logistics Demonstration Project) is included in the 2018 woody SOT for CFP. A variety of data shows the effectiveness of field drying, which is highly variable by region, species, age, and methodology. A study conducted by North Carolina State University has showed that by allowing logs to dry on the landing for a period of 330 to 360 days, the moisture content can be reduced from 50\% to approximately $18 \%$, independent of time of harvest or tree type (i.e., hardwood or softwood) (Roise et al. 2013). Because the study was completed in the same region as the defined study area, we can assume that similar results are likely and an assumption of a moisture reduction of $20 \%$ (from $50 \%$ down to $30 \%$ ) in both clean pine and forest residue is conservative. Similar studies in other areas have shown greater moisture reductions in less time (Stokes et al. 1993, Greene et al. 2014). 
When the materials reach the depot (in this case, it is collocated with the biorefinery), they are stored in uncovered piles to await being loaded into the blending hopper. The storage requirements at the conversion facility are assumed to be enough material to sustain the operation for 1 week of operation. This quantity of material is assumed to be adequate to sustain operations during periods of time when material is not supplied due to weather or other disruptions, while also not being so great that storage losses will be large due to degradation (Table C-3).

Table C-3. Key storage assumptions for the 2018 woody SOT for CFP.

\begin{tabular}{|c|c|}
\hline \multicolumn{1}{|c|}{ Component } & Clean Pine \\
\hline Field Side Storage & Uncovered pile \\
\hline Type & None \\
\hline Ground Cover & $<1 \%$ \\
\hline Material Loss (\%) & \\
\hline Storage at Preprocessing & Uncovered pile \\
\hline Type & Asphalt pad \\
\hline Ground Cover & $2 \%$ \\
\hline Material Loss (\%) & 6 \\
\hline Days of Supply & \\
\hline
\end{tabular}

\section{A.16 Transportation and Handling}

Transportation includes all processes involved in movement of material to a centralized location (such as a preprocessing facility or to the biorefinery). Transportation includes processes such as loading, trucking, rail transport, and unloading. Beyond transportation, additional handling is required to transfer and queue biomass to the conversion facility. Surge bins, conveyors, dust collection, and miscellaneous equipment are used in handling operations. Handling operations depend on many factors, including biomass moisture content, bulk density, and particle size and shape distribution. Lignocellulosic feedstock inherently possesses characteristics that inhibit handling (e.g., high cohesivity, low density, high compressibility, and high variability in particle size and shape uniformity) (Kenney et al. 2013). For this reason, lignocellulosic feedstock handling operations are typically designed at $150 \%$ of design capacity in order to accommodate variability in biomass handling properties.

The 2018 woody SOT for CFP uses truck transportation to transport the material. The clean pine material is transported as logs on log trailers with a capacity of 4,000 $\mathrm{ft}^{3}$. 
Table C-4. Key transportation and handling assumptions for the 2018 woody SOT for CFP.

\begin{tabular}{|l|c|}
\hline \multicolumn{1}{|c|}{ Component } & Clean Pine \\
\hline Truck & \\
\hline Type & Day cab \\
\hline Transportation Distance (mi) & 219 \\
\hline Speed (mph) & 50 \\
\hline Trailer & \\
\hline Type & Log Trailers \\
\hline Volume & $3,600 \mathrm{ft}^{3}$ \\
\hline Dry Bulk Density & $11 \mathrm{lb} / \mathrm{ft}^{3}$ \\
\hline Moisture Content & $30 \%$ \\
\hline
\end{tabular}

\section{A.1 Landing Preprocessing}

With clean pine the only processing operation at the landing is delimbing, Delimbing is accomplished just prior to stacking for storage using a delimbing gate. It is worth noting that use of the delimbing gate resulted in reduced productivity of the grapple skidder, since the stems are manually forced through a metal grid by the skidder to remove the branches.

Table C-5. Key landing preprocessing assumptions for the 2018 woody SOT for CFP.

\begin{tabular}{|c|c|}
\hline \multicolumn{1}{|c|}{ Component } & Clean Pine \\
\hline Delimb & Delimbing Gate \\
\hline Type & 50 \\
\hline Capacity (ton/hour) & 5 \\
\hline Dry Matter Loss (\%) & \\
\hline
\end{tabular}

\section{A.2 Preprocessing}

The materials are offloaded at the facility using a truck tipper with a hopper, where they are transported to storage by a conveyor. Depot operations include processing operations required to create a uniform feedstock for distribution and use in the conversion process. In addition to processing of the feedstock, depot operations may also include necessary auxiliary operations (such as dust collection and conveyor) to move material from one operation to the next.

The 2018 woody SOT for CFP preprocessing operations include debarking, size reduction, high moisture densification, and drying. The logs are first debarked and set to the initial size reduction. Initial size reduction is completed using a centralized chipper. The chips are further size reduced using the rotary shear. The benefit of the rotary shear over the more traditional hammer mill is that energy consumption is reduced and distribution of particle sizes is reduced. The rotary shear uniformly reduces the size of the material to a particle size of $0.25 \mathrm{in}$. or below 


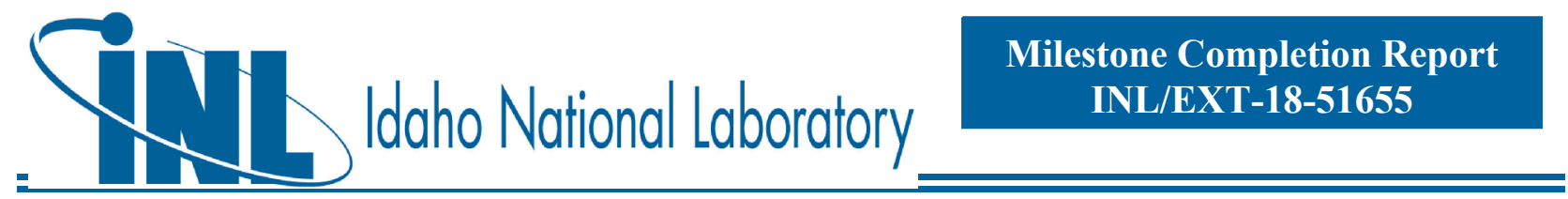

in preparation for pelleting. The rotary sheard material is then conveyed to densification where the pellets are produced and then dried in a cross flow drier.

Table C-6. Assumptions of key depot operations, including blending, in the 2018 woody SOT for CFP.

\begin{tabular}{|c|c|}
\hline Component & Clean Pine \\
\hline \multicolumn{2}{|l|}{ Loader } \\
\hline Capacity & 120 ton/hour \\
\hline \multicolumn{2}{|l|}{ Chipper } \\
\hline Energy & $19.3 \mathrm{kWh}$ \\
\hline Capacity & 25 ton/hour \\
\hline \multicolumn{2}{|l|}{ Debarker } \\
\hline Horsepower & 50 \\
\hline Capacity & 80 ton/hour \\
\hline Dry Matter Loss & $3 \%$ \\
\hline \multicolumn{2}{|l|}{ Dryer } \\
\hline Capacity & 4.8 ton/hour \\
\hline Energy & $50 \mathrm{kWh} /$ ton \\
\hline Waste Heat & $0 \%$ \\
\hline $\begin{array}{l}\text { Moisture } \\
\text { Reduction }\end{array}$ & $20 \%$ \\
\hline \multicolumn{2}{|l|}{ Rotary Shear } \\
\hline Capacity & 7.5 ton/hour \\
\hline Energy & $33.85 \mathrm{kWh} /$ ton \\
\hline Screen Size & $1 / 4$-in \\
\hline $\begin{array}{l}\text { Operating } \\
\text { Conditions }\end{array}$ & $20 \%$ moisture \\
\hline Dry Matter Loss & $5 \%$ \\
\hline \multicolumn{2}{|l|}{ Densifier } \\
\hline Capacity & 5 ton/hour \\
\hline Energy & $103 \mathrm{kWh} /$ ton \\
\hline
\end{tabular}




\section{APPENDIX D - 2022 Projection for Woody Feedstock Logistics Design and Assumptions for Feedstock Supply to CFP}

The 2022 woody design for CFP (Figure D-1) consists of $25 \%$ clean pine and $75 \%$ Logging Residue which supplies 725,000 dry tons of biomass annually to the throat of the conversion reactor. Clean pine is harvested and preprocessed using a modified ground-based mechanized chip production system that is based on the system that was studied by Auburn University during their High Tonnage Logistics Demonstration Project. All materials are transported to a processing facility. During preprocessing, the materials are processed into pellets before being blended to create a feedstock of uniform quality for use in the biorefinery.

The model relies on assumptions about exogenous factors such as interest rates, energy prices, and land rents. The prices for electricity, natural gas, and off-road diesel were updated to more accurately reflect market conditions. Table D-1 shows the updates that were used.

Table D-1 Updated energy prices and interest rates used to model feedstock logistics costs for the 2022 woody design for CFP

\begin{tabular}{|l|c|c|}
\multicolumn{1}{|c|}{ Component } & $\mathbf{2 0 1 8}$ Assumptions & $\mathbf{2 0 2 2}$ Assumptions \\
\hline Interest Rate & $8 \% \mathrm{a}$ & $8 \% \mathrm{a}$ \\
\hline Electricity Price & $\$ 0.0672 / \mathrm{kWh}$ & $\$ 0.0672 / \mathrm{kWh}$ \\
\hline Natural Gas Price & $\$ 3.36 / \mathrm{MMBtub}$ & $\$ 3.36 / \mathrm{MMBtub}$ \\
\hline Off-Road Diesel Price & $\$ 2.01 / \mathrm{gal}_{\mathrm{d}}$ & $\$ 2.01 / \mathrm{gal}_{\mathrm{d}}$ \\
\hline
\end{tabular}

aJones et al. 2013.

bEIA 2017

\section{A.3 Grower Payment}

Grower payment represents the stumpage price paid to the landowner to secure permission to harvest the material. The grower payment was calculated using the size class stumpage values reported in the 2016 Billion Ton Report (BT16; USDOE, 2016) and BT16 provides values of $\$ 32.40$ /dry ton, $\$ 16.20$ /dry ton and $\$ 8.10$ /dry ton, for both planted and natural softwood stands, of size classes 1, 2 and 3, respectively in the Southern Region. The calculation of forest residue grower payment utilizes the residue ratios from the USDA Forest Service Forest Inventory and Analysis Database (USDA Forest Service, 2017), to determine the proportion of the value of the whole tree stumpage that remains after the harvest as residue. Based on the assumed harvest region, the size class distribution of delivered material and residue ratio, the weighted average grower payment of Forest residue is $\$ 3.75 /$ dry ton. 


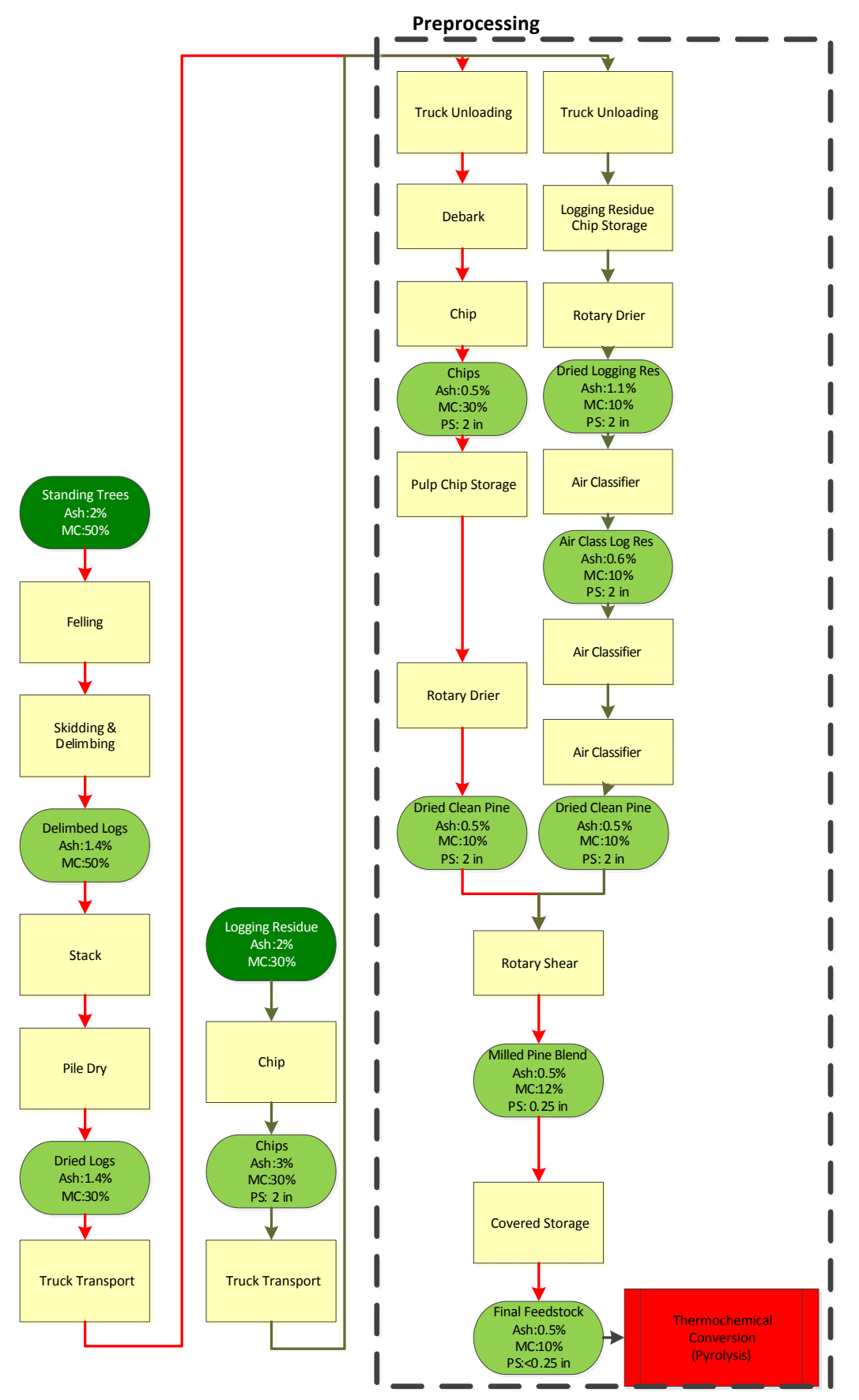

Figure D-1. 2016 woody SOT feedstock supply system design supporting thermochemical conversion. 


\section{A.4 Harvest and Collection}

The harvest of clean pine for energy is similar to harvest of materials for the production of paper or lumber, using integrated activities to prepare the raw material for transport from the field to the processing facility (Wang et al. 2013). The 2022 woody design for CFP maintains the same type of system for clean pine harvest and collection that had been used previously and is based on the system studied in the DOE High-Tonnage Biomass Logistics Demonstration Project carried out by Auburn University. The system uses a tracked feller buncher with a high speed shear for felling the clean pine-sized material. Collection and primary transportation is completed using a grapple skidder with an oversized grapple to increase payload. Felling production using the feller buncher is 49 dry tons per hour. (Cafferty and Hartley 2015, Sokhansanj et al. 2014, Jernigan 2012). Collection of the material is completed through use of a grapple skidder with a capacity of 40 dry tons per hour (Cafferty and Hartley 2015, Sokhansanj et al. 2014, Jernigan 2012). Forest residues are considered a byproduct of harvest and the cost of harvesting is associated with the main products.

Table D-2. Key harvest and collection assumptions for the 2018 woody design for CFP.

\begin{tabular}{|c|c|}
\hline Component & Clean Pine \\
\hline \multicolumn{2}{|l|}{ Harvest Machine } \\
\hline Type & Feller-buncher \\
\hline Rated Capacity (ton/hour) & 75.38 \\
\hline Utilization (\%) & 65 \\
\hline \multicolumn{2}{|l|}{ Collection Machine } \\
\hline Type & Grapple skidder \\
\hline Rated Capacity (ton/hour) & 62 \\
\hline Utilization (\%) & 65 \\
\hline Average Extraction Distance (feet) & 1,500 \\
\hline Initial Moisture Content & $50 \%$ \\
\hline Field Dry Moisture Content & $30 \%$ \\
\hline Operation Hours & $\begin{array}{c}50 \text { week/year, } \\
5 \text { day/week, } \\
8 \text { hour/day }\end{array}$ \\
\hline
\end{tabular}

\section{A.5 Storage}

Storage involves stockpiling material to provide an adequate lead time for downstream processes and accumulating material quantities for economical transportation. Woody biomass is subject to degradation by fungi, yeast, and bacteria that alter the feedstock's composition. Degradation is a more prevalent problem in comminuted biomass, which has a higher surface area exposed and accessible to the damaging agents. Conversely, if the woody biomass is stored as uncomminuted material, the material is stable and can be kept for periods greater than a year 
without experiencing a reduction in quality (Nurmi 2014, Erber et al. 2014, Ackerman et al. 2014). The additional benefit of storage in the field is that the material dries during that time, reducing the moisture content before transportation (Stokes et al. 1993).

Field drying during storage (first included in the 2014 woody SOT and is also a key component of Auburn's High Tonnage Logistics Demonstration Project) is included in the 2016 woody SOT (Cafferty and Hartley 2015, Sokhansanj et al. 2014). A variety of data shows the effectiveness of field drying, which is highly variable by region, species, age, and methodology. A study conducted by North Carolina State University has showed that by allowing logs to dry on the landing for a period of 330 to 360 days, the moisture content can be reduced from $50 \%$ to approximately $18 \%$, independent of time of harvest or tree type (i.e., hardwood or softwood) (Roise et al. 2013). Because the study was completed in the same region as the defined study area, we can assume that similar results are likely and an assumption of a moisture reduction of $20 \%$ (from $50 \%$ down to $30 \%$ ) in both clean pine and forest residue is conservative. Similar studies in other areas have shown greater moisture reductions in less time (Stokes et al. 1993, Greene et al. 2014).

When the materials reach the depot (in this case, it is collocated with the biorefinery), they are stored in uncovered piles to await being loaded into the blending hopper. The storage requirements at the conversion facility are assumed to be enough material to sustain the operation for 1 week of operation. This quantity of material is assumed to be adequate to sustain operations during periods of time when material is not supplied due to weather or other disruptions, while also not being so great that storage losses will be large due to degradation (Table D-3).

Table D-3. Key storage assumptions for the 2022 woody design for CFP.

\begin{tabular}{|c|c|c|}
\hline Component & Clean Pine & Forest Residue \\
\hline \multicolumn{3}{|l|}{ Field Side Storage } \\
\hline Type & Uncovered pile & Uncovered pile \\
\hline Ground Cover & None & None \\
\hline Material Loss (\%) & $<1 \%$ & $<1 \%$ \\
\hline \multicolumn{3}{|l|}{ Storage at Preprocessing } \\
\hline Type & Uncovered pile & Uncovered pile \\
\hline Ground Cover & Asphalt pad & Asphalt pad \\
\hline Material Loss (\%) & $2 \%$ & $2 \%$ \\
\hline Days of Supply & 6 & 6 \\
\hline
\end{tabular}

\section{A.6 Transportation and Handling}

Transportation includes all processes involved in movement of material to a centralized location (such as a preprocessing facility or to the biorefinery). Transportation includes processes such as loading, trucking, rail transport, and unloading. Beyond transportation, additional handling is required to transfer and queue biomass to the conversion facility. Surge 
bins, conveyors, dust collection, and miscellaneous equipment are used in handling operations. Handling operations depend on many factors, including biomass moisture content, bulk density, and particle size and shape distribution. Lignocellulosic feedstock inherently possesses characteristics that inhibit handling (e.g., high cohesivity, low density, high compressibility, and high variability in particle size and shape uniformity) (Kenney et al. 2013). For this reason, lignocellulosic feedstock handling operations are typically designed at $150 \%$ of design capacity in order to accommodate variability in biomass handling properties.

The 2022 woody design for CFP uses truck transportation to transport the material. The clean pine material is transported as logs on log trailers with a capacity of $3,600 \mathrm{ft}^{3}$, while the forest residues is transported as chips in a chip van with a capacity of $4,000 \mathrm{ft}^{3}$.

Table D-4. Key transportation and handling assumptions for the 2022 woody design for CFP.

\begin{tabular}{|c|c|c|}
\hline \multicolumn{1}{|c|}{ Component } & Clean Pine & Forest Residue \\
\hline Truck & & Day cab \\
\hline Transportation Distance (mi) & 32 & 112 \\
\hline Speed (mph) & 50 & 50 \\
\hline Trailer & & \\
\hline Type & Log Trailers & Possum Belly \\
\hline Volume & $3,600 \mathrm{ft}^{3}$ & $4000 \mathrm{ft}^{3}$ \\
\hline Dry Bulk Density & $20 \mathrm{lb} / \mathrm{ft}^{3}$ & $11 \mathrm{lb} / \mathrm{ft}^{3}$ \\
\hline Moisture Content & $30 \%$ & $30 \%$ \\
\hline
\end{tabular}

\section{A.7 Landing Preprocessing}

With clean pine the only processing operation at the landing is delimbing, Delimbing is accomplished just prior to stacking for storage using a delimbing gate. It is worth noting that use of the delimbing gate resulted in reduced productivity of the grapple skidder, since the stems are manually forced through a metal grid by the skidder to remove the branches. For the forest residue the material is chipped at the landing and blown into the trailers for transport.

Table D-5. Key landing preprocessing assumptions for the 2022 Projection for CFP.

\begin{tabular}{|c|c|c|}
\hline \multicolumn{1}{|c|}{ Component } & Clean Pine & Forest Residue \\
\hline Type & & - \\
\hline Capacity (ton/hour) & Delimbing Gate & - \\
\hline Dry Matter Loss (\%) & 50 & - \\
\hline Chipper & 5 & \\
\hline Capacity & - & $79.8 \mathrm{ton} / \mathrm{hour}$ \\
\hline Energy Consumption & - & $18.5 \mathrm{kWh} / \mathrm{ton}$ \\
\hline
\end{tabular}




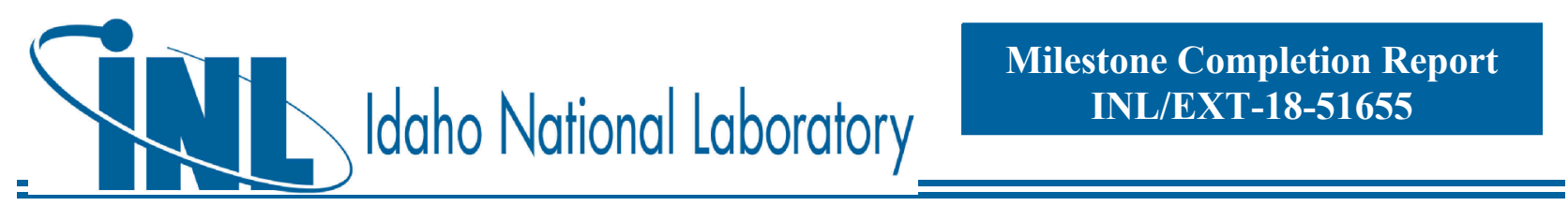

\begin{tabular}{|l|c|c|} 
Dry Matter Loss (\%) & - & 5 \\
\hline
\end{tabular}

\section{A.1 Preprocessing}

The materials are offloaded at the facility using a truck tipper with a hopper, where they are transported to storage by a conveyor. Depot operations include processing operations required to create a uniform feedstock for distribution and use in the conversion process. In addition to processing of the feedstock, depot operations may also include necessary auxiliary operations (such as dust collection and conveyor) to move material from one operation to the next.

The 2018 woody design for CFP preprocessing operations include debarking, size reduction, high moisture densification, and drying. The logs are first debarked and set to the initial size reduction. Initial size reduction is completed using a centralized chipper. The chips are further size reduced using the rotary shear. The benefit of the rotary shear over the more traditional hammer mill is that energy consumption is reduced and distribution of particle sizes is reduced. The rotary shear uniformly reduces the size of the material to a particle size of $0.25 \mathrm{in}$. or below. 
Table D-6. Assumptions of key processing operations in the 2022 woody design for CFP.

\begin{tabular}{|c|c|c|}
\hline Component & \multirow[t]{2}{*}{ Clean Pine } & \multirow[t]{2}{*}{ Logging Residue } \\
\hline Loader & & \\
\hline Capacity & 120 ton/hour & - \\
\hline \multicolumn{3}{|l|}{ Chipper } \\
\hline Energy & $19.3 \mathrm{kWh}$ & - \\
\hline Capacity & 25 ton/hour & - \\
\hline \multicolumn{3}{|l|}{ Debarker } \\
\hline Horsepower & 50 & - \\
\hline Capacity & 80 ton/hour & - \\
\hline Dry Matter Loss & $3 \%$ & - \\
\hline \multicolumn{3}{|l|}{ Dryer } \\
\hline Capacity & 1.5 ton/hour & 1.5 ton/hour \\
\hline Energy & $350 \mathrm{kWh} /$ ton & $350 \mathrm{kWh} /$ ton \\
\hline Waste Heat & $0 \%$ & $0 \%$ \\
\hline Moisture Reduction & $20 \%$ & $20 \%$ \\
\hline \multicolumn{3}{|l|}{ Rotary Shear } \\
\hline Capacity & 7.5 ton/hour & 7.5 ton/hour \\
\hline Energy & $33.85 \mathrm{kWh} / \mathrm{ton}$ & $33.85 \mathrm{kWh} /$ ton \\
\hline Screen Size & $1 / 4$-in & $1 / 4$-in \\
\hline Operating Conditions & $20 \%$ moisture & $20 \%$ moisture \\
\hline Dry Matter Loss & $5 \%$ & $5 \%$ \\
\hline \multicolumn{3}{|c|}{ Air Classification and Leaching } \\
\hline Capacity & - & 8.39 \\
\hline Horsepower & - & 10 \\
\hline Dry Matter Loss & - & $6 \%$ \\
\hline
\end{tabular}




\section{APPENDIX E - 2018 Woody State of Technology Feedstock Logistics Design and Assumptions for Forest Residue Supply to AHTL}

The 2018 woody SOT for AHTL (Figure E-1) consists of 100\% forest residue, and supplies 35,752 dry tons of biomass annually to the throat of the conversion reactor. The forest residues are preprocessed at the roadside using a system that is based on the chip processing system that was studied by Auburn University during their High Tonnage Logistics Demonstration Project. The processed forest residues are transported from their aggregation points after preprocessing. The materials are delivered directly to the biorefinery, where they are dried using process heat before being delivered to the throat of the reactor.



Figure E-1. 2018 woody SOT feedstock supply system design supporting thermochemical conversion.

The model relies on assumptions about exogenous factors such as interest rates, energy prices, and land rents. The prices for electricity, natural gas, and off-road diesel were updated to more accurately reflect market conditions. Table E-1 shows the assumptions used.

Table E-1 Updated energy prices and interest rates used to model feedstock logistics costs for the 2018 woody SOT for AHTL.

\begin{tabular}{|l|c|c|}
\multicolumn{1}{|c|}{ Component } & 2017 Assumptions & 2018 Assumptions \\
\hline Interest Rate & $8 \% \mathrm{a}$ & $8 \% \mathrm{a}$ \\
\hline Electricity Price & $\$ 0.0672 / \mathrm{kWh} b$ & $\$ 0.0672 / \mathrm{kWh} b$ \\
\hline Natural Gas Price & $\$ 3.36 / \mathrm{MMBtub}$ & $\$ 3.36 / \mathrm{MMBtub}$ \\
\hline Off-Road Diesel Price & $\$ 2.01 /$ gald $_{\mathrm{d}}$ & $\$ 2.01 / \mathrm{gal}_{\mathrm{d}}$ \\
\hline
\end{tabular}

aJones et al. 2013.

bEIA 2017

\section{A.17 Grower Payment}

Grower payment ${ }^{3}$ represents the stumpage price paid to the landowner to secure permission to harvest the material. The grower payment was calculated using the size class stumpage values 
reported in the 2016 Billion Ton Report (57\% Size Class 1, 43\% Size Class 2; BT16; USDOE, 2016) and the residue ratios from the USDA Forest Service Forest Inventory and Analysis Database (15\% for Size Class 1, 14\% for size Class 2; USDA Forest Service, 2017). BT16 provides values of $\$ 32 /$ dry ton, $\$ 16 /$ dry ton and $\$ 8 /$ dry ton, for both planted and natural softwood stands, of size classes 1, 2 and 3, respectively in the Southern Region. Based on the assumed harvest region, the size class distribution of delivered material and residue ratio, leads to a weighted average grower payment of $\$ 3.70$ /dry ton.

\section{A.18 Harvest and Collection}

The 2018 woody SOT for IDL utilizes only forest residues. Forest residues are materials, in the form of limbs, tops, cutoffs, and/or culled material that originate from the harvest of saw log material. This material is accumulated at the landing as saw logs are processed and stored in piles. Because the material is a byproduct of saw log processing, the cost of harvest and collection are not attributed to the material.

\section{A.19 Storage}

Storage involves stockpiling material to provide an adequate lead time for downstream processes and accumulating material quantities for economical transportation. Woody biomass is subject to degradation by fungi, yeast, and bacteria that alter the feedstock's composition. Degradation is a more prevalent problem in comminuted biomass, which has a higher surface area exposed and accessible to the damaging agents. Conversely, if the woody biomass is stored as uncomminuted material, the material is stable and can be kept for periods greater than a year without experiencing a reduction in quality (Nurmi 2014, Erber et al. 2014, and Ackerman et al. 2014). The additional benefit of storage in the field is that the material dries during that time, reducing the moisture content before transportation (Stokes et al. 1993).

Field drying during storage (first included in the 2014 woody SOT and is also a key component of Auburn's High Tonnage Logistics Demonstration Project (Cafferty and Hartley 2015, Sokhansanj et al. 2014) is included in the 2018 woody SOT for IDL. A variety of data shows the effectiveness of field drying, which is highly variable by region, species, age, and methodology. A study conducted by North Carolina State University has showed that by allowing logs to dry on the landing for a period of 330 to 360 days, the moisture content can be reduced from 50\% to approximately $18 \%$, independent of time of harvest or tree type (i.e., hardwood or softwood) (Roise et al. 2013). Because the study was completed in the same region as the defined study area, we can assume that similar results are likely and an assumption of a moisture reduction of $20 \%$ (from $50 \%$ down to $30 \%$ ) in both clean pine and forest residue is conservative. Similar studies in other areas have shown greater moisture reductions in less time (Stokes et al. 1993, Greene et al. 2014).

When the materials reach the refinery they are stored in uncovered piles to await drying. The storage requirements at the conversion facility are assumed to be enough material to sustain the operation for 1 week of operation. This quantity of material is assumed to be adequate to sustain operations during periods of time when material is not supplied due to weather or other

\footnotetext{
${ }^{3}$ Grower payment is the road-side selling price, less any preprocessing costs that are incurred.
} 
disruptions, while also not being so great that storage losses will be large due to degradation (Table E-2).

Table E-2. Key storage assumptions for the 2018 woody SOT for AHTL.

\begin{tabular}{|l|c|}
\hline \multicolumn{1}{|c|}{ Component } & Forest Res. \\
\hline Fieldside & \\
\hline Type & Uncovered pile \\
\hline Ground Cover & None \\
\hline Material Loss (\%) & $<1 \%$ \\
\hline Biorefinery & \\
\hline Type & Uncovered pile \\
\hline Ground Cover & Asphalt pad \\
\hline Material Loss (\%) & $2 \%$ \\
\hline Days of Supply & 6 \\
\hline
\end{tabular}

\section{A.20 Landing Preprocessing}

The landing is the location where forest materials are initially aggregated, stored, and processed for transport and sale after harvest. Landing preprocessing is used to improve the transportation and handling characteristics of the biomass feedstocks. Landing processing is designed to increase the bulk density and/or remove materials that will be considered waste further along the supply chain. Through both increasing density and removing waste materials, transportation cost for the material is reduced and subsequent processing is made more efficient.

Landing preprocessing for the forest residues included in the 2018 woody SOT for IDL blend begins before transportation to the depot. In this design the only preprocessing at the landing is chipping. The forest residues are chipped to a 2-in. chip using a mobile disk chipper. Production and fuel consumption for the chipper were taken from the DOE HighTonnage Biomass Logistics Demonstration Project that was carried out by Auburn University. This project looked at both chipping tree length material and the effect of field drying on chipping operations. The chips are then loaded into the chip trailer by the loader blowing the chips from the out feed (Table E-3).

Forest residue is processed at the landing in much the same way as clean pine by first going through a flail debarker and then chipped using a disk chipper. It was assumed that the throughput for the chipper would be the same as for clean pine operation, but the cleanup operation would be less effective with the processed forest residue having approximately $1.25 \%$ compared to the $0.5 \%$ ash in the clean pine. Additionally, attempting to clean-up forest residues is assumed to result in a $40 \%$ material loss. The chips are also loaded into the chip trailers by blowing the chips from the outfeed of the chipper (Table E-3). 
Table E-3. Key landing preprocessing assumptions for the 2018 SOT for AHTL.

\begin{tabular}{|c|c|}
\hline Component & Forest Res. \\
\hline \multicolumn{2}{|l|}{ Loader } \\
\hline Type & Knuckle boom \\
\hline Capacity (ton/hr) & 75.6 \\
\hline \multicolumn{2}{|l|}{ Size Reduction } \\
\hline Type & Chipper \\
\hline Capacity (ton/hour) & 79.8 \\
\hline Dry Matter Loss (\%) & 5 \\
\hline Particle Size & $2 \mathrm{in.}$ \\
\hline Moisture Content & $30 \%$ \\
\hline
\end{tabular}

\section{A.21 Transportation and Handling}

Transportation includes all processes involved in movement of material to a centralized location (such as a preprocessing facility or to the biorefinery). Transportation includes processes such as loading, trucking, rail transport, and unloading. Beyond transportation, additional handling is required to transfer and queue biomass to the conversion facility. Surge bins, conveyors, dust collection, and miscellaneous equipment are used in handling operations. Handling operations depend on many factors, including biomass moisture content, bulk density, and particle size and shape distribution. Lignocellulosic feedstock inherently possesses characteristics that inhibit handling (e.g., high cohesivity, low density, high compressibility, and high variability in particle size and shape uniformity) (Kenney et al. 2013). For this reason, lignocellulosic feedstock handling operations are typically designed at $150 \%$ of design capacity in order to accommodate variability in biomass handling properties.

The 2018 woody SOT for AHTL uses truck transportation to the depot/biorefinery (Table E-4). The forest residues are blown from the chipper into possum belly open back trailers with a capacity of 4,000 $\mathrm{ft}_{3}$. The material is assumed to have a dry bulk density of $11 \mathrm{lb} / \mathrm{ft}_{3}$ (Harris and Phillips 1986) and the assumed moisture content at transportation is $30 \%$ (wet basis) (Greene et al, 2014). This resulted in a calculated weight-limited payload of 17.68 dry ton/load for the forest residue material. The draw radius for the forest residue was 88 miles, based on material availability.

Table E-4. Key transportation and handling assumptions for the 2018 woody SOT for AHTL.

\begin{tabular}{|l|l|}
\hline Component & Forest Residue \\
\hline Truck & \\
\hline Type & Day Cab \\
\hline
\end{tabular}




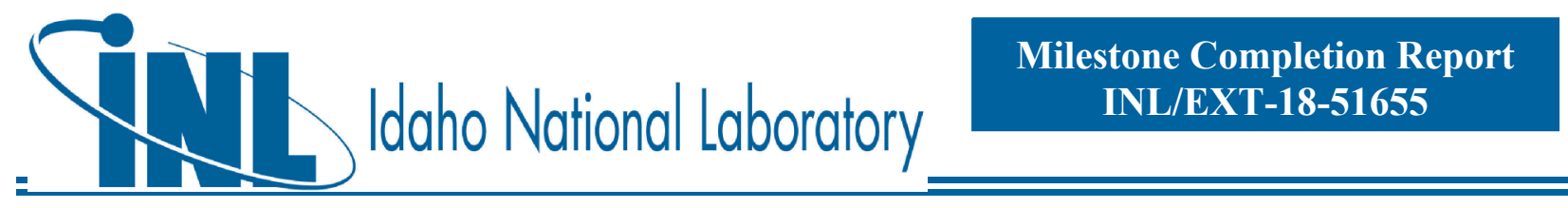

\begin{tabular}{|l|l|}
\hline Transportation Distance (mi) & 88 \\
\hline Speed (mph) & 50 \\
\hline Trailer & \\
\hline Type & Open back possum belly \\
\hline Volume & $4,000 \mathrm{ft}^{3}$ \\
\hline Dry Bulk Density & $11 \mathrm{lb} / \mathrm{ft}^{3}$ \\
\hline Moisture Content & $30 \%$ \\
\hline
\end{tabular}

\section{A.22 Processing Operations}

The materials are offloaded at the facility using a truck tipper with a hopper, where they are transported to storage by a conveyor. Depot operations include processing operations required to create a uniform feedstock for distribution and use in the conversion process. In addition to processing of the feedstock, depot operations may also include necessary auxiliary operations (such as dust collection and conveyor) to move material from one operation to the next.

The 2018 woody SOT for AHTL refinery operations include only drying using process heat (Table E-5). The material is dried to $10 \%$ moisture content (wet basis) in a rotary drier. After drying, the forest residues are size reduced to less than $2 \mathrm{~mm}$ and placed in queue for feeding to the reactor.

Table E-5. Assumptions of key preprocessing operations in the 2018 woody SOT for AHTL.

\begin{tabular}{|l|l|}
$\begin{array}{l}\text { Component } \\
\text { Loader }\end{array}$ \\
\hline $\begin{array}{l}\text { Capacity } \\
\text { Drver }\end{array}$ & $120 \mathrm{ton} / \mathrm{hr}$ \\
\hline Capacity & $1.5 \mathrm{ton} / \mathrm{hr}$ \\
\hline Energy & $350 \mathrm{kWh} / \mathrm{ton}$ \\
\hline Waste Heat & $0 \%$ \\
\hline Moisture Reduction & $20 \%$ \\
\hline
\end{tabular}




\section{APPENDIX F - 2022 Projection for Woody Feedstock Logistics Design and Assumptions for Forest Residue Supply to AHTL}

The 2022 woody design case for AHTL (Figure F-1) consists of 100\% forest residue, and supplies 35,752 dry tons of biomass annually to the throat of the conversion reactor. The forest residues are preprocessed at the roadside using a system that is based on the chip processing system that was studied by Auburn University during their High Tonnage Logistics Demonstration Project. The processed forest residues are transported from their aggregation points after preprocessing. The materials are delivered directly to the biorefinery, where they are dried using process heat before being delivered to the throat of the reactor.

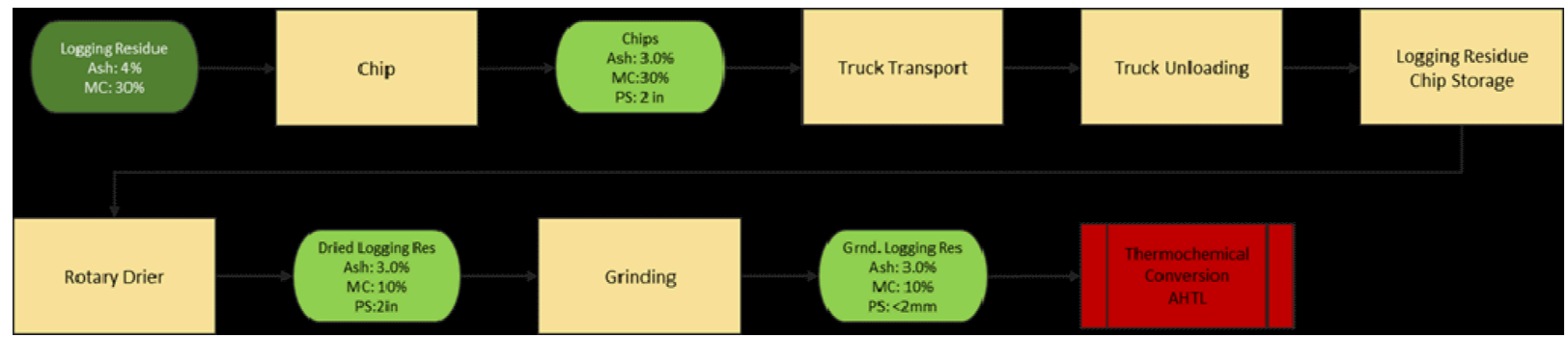

Figure F-1. 2022 woody feedstock supply system design supporting AHTL conversion.

The model relies on assumptions about exogenous factors such as interest rates, energy prices, and land rents. The prices for electricity, natural gas, and off-road diesel were updated to more accurately reflect market conditions. Table F-1 shows the values of the assumptions used.

Table F-1 Updated energy prices and interest rates used to model feedstock logistics costs for the 2022 woody design for AHTL.

\begin{tabular}{|l|c|c|}
\multicolumn{1}{|c|}{ Component } & $\mathbf{2 0 1 8}$ Assumptions & $\mathbf{2 0 2 2}$ Assumptions \\
\hline Interest Rate & $8 \% \mathrm{a}$ & $8 \% \mathrm{a}$ \\
\hline Electricity Price & $\$ 0.0672 / \mathrm{kWh}$ & $\$ 0.0672 / \mathrm{kWh}$ \\
\hline Natural Gas Price & $\$ 3.36 / \mathrm{MMBtub}$ & $\$ 3.36 / \mathrm{MMBtub}$ \\
\hline Off-Road Diesel Price & $\$ 2.01 / \mathrm{gal}_{\mathrm{d}}$ & $\$ 2.01 / \mathrm{gald}_{\mathrm{d}}$ \\
\hline
\end{tabular}

aJones et al. 2013.

bEIA 2017 


\section{A.23 Grower Payment}

Grower payment ${ }^{4}$ represents the stumpage price paid to the landowner to secure permission to harvest the material. The grower payment was calculated using the size class stumpage values reported in the 2016 Billion Ton Report (57\% Size Class 1, 43\% Size Class 2; BT16; USDOE, 2016) and the residue ratios from the USDA Forest Service Forest Inventory and Analysis Database (15\% for Size Class 1, 14\% for size Class 2; USDA Forest Service, 2017). BT16 provides values of $\$ 32 /$ dry ton, $\$ 16 /$ dry ton and $\$ 8 /$ dry ton, for both planted and natural softwood stands, of size classes 1, 2 and 3, respectively in the Southern Region. Based on the assumed harvest region, the size class distribution of delivered material and residue ratio, leads to a weighted average grower payment of $\$ 3.70 /$ dry ton.

\section{A.24 Harvest and Collection}

The 2022 woody design for AHTL utilizes only forest residues. Forest residues are materials, in the form of limbs, tops, cutoffs, and/or culled material that originate from the harvest of saw $\log$ material. This material is accumulated at the landing as saw logs are processed and stored in piles. Because the material is a byproduct of saw log processing, the cost of harvest and collection are not attributed to the material.

\section{A.25 Storage}

Storage involves stockpiling material to provide an adequate lead time for downstream processes and accumulating material quantities for economical transportation. Woody biomass is subject to degradation by fungi, yeast, and bacteria that alter the feedstock's composition. Degradation is a more prevalent problem in comminuted biomass, which has a higher surface area exposed and accessible to the damaging agents. Conversely, if the woody biomass is stored as uncomminuted material, the material is stable and can be kept for periods greater than a year without experiencing a reduction in quality (Nurmi 2014, Erber et al. 2014, and Ackerman et al. 2014). The additional benefit of storage in the field is that the material dries during that time, reducing the moisture content before transportation (Stokes et al. 1993).

Field drying during storage (first included in the 2014 woody SOT and is also a key component of Auburn's High Tonnage Logistics Demonstration Project is included in the 2022 woody design for AHTL. A variety of data shows the effectiveness of field drying, which is highly variable by region, species, age, and methodology. A study conducted by North Carolina State University has showed that by allowing logs to dry on the landing for a period of 330 to 360 days, the moisture content can be reduced from $50 \%$ to approximately $18 \%$, independent of time of harvest or tree type (i.e., hardwood or softwood) (Roise et al. 2013). Because the study was completed in the same region as the defined study area, we can assume that similar results are likely and an assumption of a moisture reduction of $20 \%$ (from $50 \%$ down to $30 \%$ ) in both clean pine and forest residue is conservative. Similar studies in other areas have shown greater moisture reductions in less time (Stokes et al. 1993, Greene et al. 2014).

\footnotetext{
${ }^{4}$ Grower payment is the road-side selling price, less any preprocessing costs that are incurred.
} 
When the materials reach the refinery they are stored in uncovered piles to await drying. The storage requirements at the conversion facility are assumed to be enough material to sustain the operation for 1 week of operation. This quantity of material is assumed to be adequate to sustain operations during periods of time when material is not supplied due to weather or other disruptions, while also not being so great that storage losses will be large due to degradation (Table F-2).

Table F-2 Key storage assumptions for the 2022 Projection for AHTL.

\begin{tabular}{|l|c|}
\hline \multicolumn{1}{|c|}{ Component } & Forest Res. \\
\hline Fypldside & Uncovered pile \\
\hline Ground Cover & None \\
\hline Material Loss (\%) & $<1 \%$ \\
\hline Biorefinery & \\
\hline Type & Uncovered pile \\
\hline Ground Cover & Asphalt pad \\
\hline Material Loss (\%) & $2 \%$ \\
\hline Days of Supply & 6 \\
\hline
\end{tabular}

\section{A.26 Landing Preprocessing}

The landing is the location where forest materials are initially aggregated, stored, and processed for transport and sale after harvest. Landing preprocessing is used to improve the transportation and handling characteristics of the biomass feedstocks. Landing processing is designed to increase the bulk density and/or remove materials that will be considered waste further along the supply chain. Through both increasing density and removing waste materials, transportation cost for the material is reduced and subsequent processing is made more efficient.

Landing preprocessing for the forest residues included in the 2022 woody design for AHTL blend begins before transportation to the depot. In this design the only preprocessing at the landing is chipping. The forest residues are chipped to a 2-in. chip using a mobile disk chipper. Production and fuel consumption for the chipper were taken from the DOE HighTonnage Biomass Logistics Demonstration Project that was carried out by Auburn University. This project looked at both chipping tree length material and the effect of field drying on chipping operations. The chips are then loaded into the chip trailer by the loader feeding the chipper and blowing the chips from the out feed (Table F-3).

Forest residue is processed at the landing in much the same way as clean pine by first going through a flail debarker and then chipped using a disk chipper. It was assumed that the throughput for the chipper would be the same as for clean pine operation, but the cleanup operation would be less effective with the processed forest residue having approximately 
$1.25 \%$ compared to the $0.5 \%$ ash in the clean pine. Additionally, attempting to clean-up forest residues is assumed to result in a $40 \%$ material loss. The chips are also loaded into the chip trailers by blowing the chips from the outfeed of the chipper (Table F-3).

Table F-3 Key landing preprocessing assumptions for the 2022 woody design for AHTL.

\begin{tabular}{|c|c|}
\hline \multicolumn{2}{|l|}{ Component } \\
\hline Loader & \\
\hline Type & Knuckle boom \\
\hline Capacity (ton/hr) & 75.6 \\
\hline \multicolumn{2}{|l|}{ Size Reduction } \\
\hline Type & Chipper \\
\hline Capacity (ton/hour) & 79.8 \\
\hline Dry Matter Loss (\%) & 5 \\
\hline Particle Size & 2 in. \\
\hline Moisture Content & $30 \%$ \\
\hline
\end{tabular}

\section{A.27 Transportation and Handling}

Transportation includes all processes involved in movement of material to a centralized location (such as a preprocessing facility or to the biorefinery). Transportation includes processes such as loading, trucking, rail transport, and unloading. Beyond transportation, additional handling is required to transfer and queue biomass to the conversion facility. Surge bins, conveyors, dust collection, and miscellaneous equipment are used in handling operations. Handling operations depend on many factors, including biomass moisture content, bulk density, and particle size and shape distribution. Lignocellulosic feedstock inherently possesses characteristics that inhibit handling (e.g., high cohesivity, low density, high compressibility, and high variability in particle size and shape uniformity) (Kenney et al. 2013). For this reason, lignocellulosic feedstock handling operations are typically designed at $150 \%$ of design capacity in order to accommodate variability in biomass handling properties.

The 2018 woody design for AHTL uses truck transportation to the depot/biorefinery (Table F-4). The forest residues are blown from the chipper into possum belly open back trailers with a capacity of 4,000 $\mathrm{ft}_{3}$. The material is assumed to have a dry bulk density of 11 $\mathrm{lb} / \mathrm{ft}_{3}$ (Harris and Phillips 1986) and the assumed moisture content at transportation is $30 \%$ (wet basis) (Greene et al, 2014). This resulted in a calculated weight-limited payload of 17.68 dry ton/load for the forest residue material. The draw radius for the forest residue was 88 miles, based on material availability. 
Table F-4. Key transportation and handling assumptions for the 2022 woody design for AHTL.

\begin{tabular}{|c|c|}
\hline Component & Forest Residue \\
\hline \multicolumn{2}{|l|}{ Truck } \\
\hline Type & Day Cab \\
\hline Transportation Distance (mi) & 88 \\
\hline Speed (mph) & 50 \\
\hline \multicolumn{2}{|l|}{ Trailer } \\
\hline Type & Open back possum belly \\
\hline Volume & $4,000 \mathrm{ft}^{3}$ \\
\hline Dry Bulk Density & $11 \mathrm{lb} / \mathrm{ft}^{3}$ \\
\hline Moisture Content & $30 \%$ \\
\hline
\end{tabular}

\section{A.28 Handling, Refinery Operations}

The materials are offloaded at the facility using a truck tipper with a hopper, where they are transported to storage by a conveyor. Depot operations include processing operations required to create a uniform feedstock for distribution and use in the conversion process. In addition to processing of the feedstock, depot operations may also include necessary auxiliary operations (such as dust collection and conveyor) to move material from one operation to the next.

The 2022 woody design for AHTL refinery operations include only drying using process heat (Table F-5). The material is dried to $10 \%$ moisture content (wet basis) in a rotary drier using excess process heat from gasification. After drying, the forest residues are ground to less than $2 \mathrm{~mm}$ and placed in queue for feeding to the reactor.

Table F-5. Assumptions of key depot operations in the 2022 woody design for AHTL.

\begin{tabular}{|l|l|}
\begin{tabular}{|l|} 
Component \\
Loader
\end{tabular} & \multicolumn{1}{l|}{ Forest Residue } \\
\hline Capacity & $120 \mathrm{ton} / \mathrm{hr}$ \\
\hline Dryer & $1.5 \mathrm{ton} / \mathrm{hr}$ \\
\hline Capacity & $350 \mathrm{kWh} / \mathrm{ton}$ \\
\hline Energy Consumption & 0 \\
\hline Waste Heat & $20 \%$ \\
\hline Moisture Reduction
\end{tabular}




\section{APPENDIX G - Process Flow Diagrams and Mass Balances for Supply of Forest Residues to IDL - 2018 SOT}

High-level stream table information from Aspen Plus modeling output follows, for key streams associated with each process operation area. This is followed by high-level PFDs for the associated process areas. Space for stream tables was limited; below is a key to lumped components. As the stream table information focuses primarily on the high-level overall process and does not include every individual modeled stream within each process area, mass balance closure around a given unit area may not be $100 \%$.

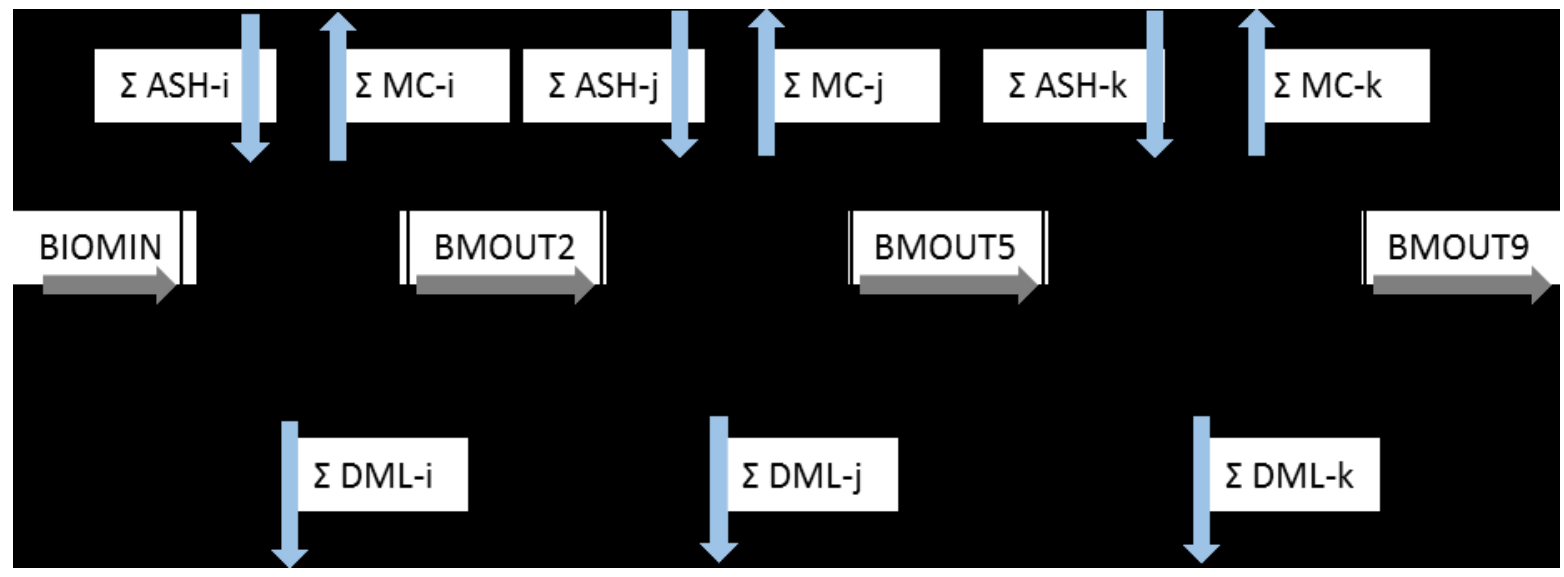

Figure G-1. High-level flowsheet showing key process areas for the Indirect Liquefaction Pathway SOT.



Figure G-2. Detailed process flow diagram for area G100-Harvesting. 




Figure G-3. Detailed process flow diagram for area G200 - Transport \& Storage.

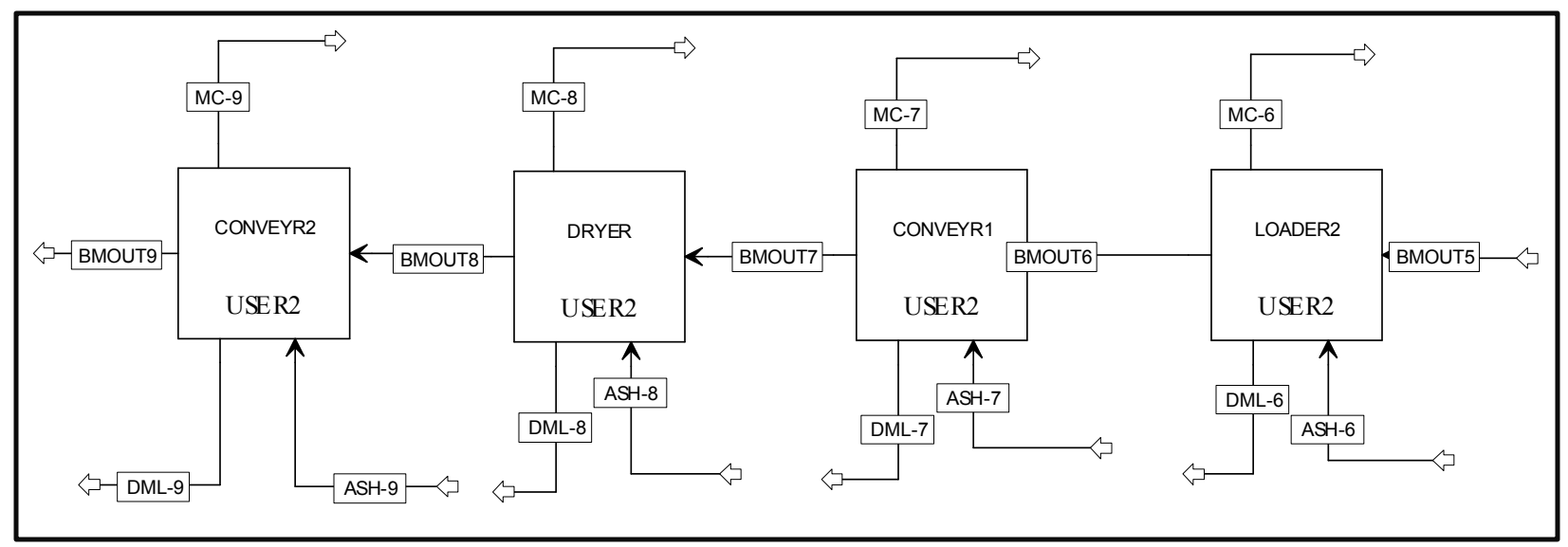

Figure G-4. Detailed process flow diagram for area G300-Preprocessing. 


\section{TII Idaho National Laboratory}

Milestone Completion

Report INL/EXT-18-

Table G-1. Aspen Plus mass balances for the Indirect Liquefaction Pathway SOT.

\begin{tabular}{|c|c|c|c|c|c|c|c|c|c|c|c|}
\hline Component & Unit & BIOMIN & DML-1 & MC-1 & BMOUT1 & DML-2 & MC-2 & BMOUT2 & DML-3 & MC-3 & BMOUT3 \\
\hline $\begin{array}{l}\text { Overall Flow (moisture } \\
\text { and dry matter) }\end{array}$ & $\mathrm{kg} / \mathrm{hr}$ & 117,718 & 0 & 0 & 117,718 & 4,121 & 5,597 & 108,001 & 0 & 0 & 108,001 \\
\hline Moisture Flow & $\mathrm{kg} / \mathrm{hr}$ & 35,316 & 0 & 0 & 35,316 & 0 & 5,597 & 29,719 & 0 & 0 & 29,719 \\
\hline Total Flow (dry matter) & $\mathrm{kg} / \mathrm{hr}$ & 82,403 & 0 & 0 & 82,403 & 4,121 & 0 & 78,282 & 0 & 0 & 78,282 \\
\hline C6 & $\mathrm{kg} / \mathrm{hr}$ & 30,513 & 0 & 0 & 30,513 & 760 & 0 & 29,753 & 0 & 0 & 29,753 \\
\hline C5 & $\mathrm{kg} / \mathrm{hr}$ & 17,634 & 0 & 0 & 17,634 & 1,192 & 0 & 16,442 & 0 & 0 & 16,442 \\
\hline LIGNIN & $\mathrm{kg} / \mathrm{hr}$ & 12,723 & 0 & 0 & 12,723 & 266 & 0 & 12,457 & 0 & 0 & 12,457 \\
\hline ASH & $\mathrm{kg} / \mathrm{hr}$ & 5,768 & 0 & 0 & 5,768 & 0 & 0 & 5,768 & 0 & 0 & 5,768 \\
\hline PROTEIN & $\mathrm{kg} / \mathrm{hr}$ & 2,497 & 0 & 0 & 2,497 & 123 & 0 & 2,373 & 0 & 0 & 2,373 \\
\hline EXTRACTIVES & $\mathrm{kg} / \mathrm{hr}$ & 11,833 & 0 & 0 & 11,833 & 1,235 & 0 & 10,598 & 0 & 0 & 10,598 \\
\hline OTHERS & $\mathrm{kg} / \mathrm{hr}$ & 1,434 & 0 & 0 & 1,434 & 543 & 0 & 891 & 0 & 0 & 891 \\
\hline Temperature & $\mathrm{K}$ & 298 & 298 & 298 & 298 & 298 & 298 & 298 & 298 & 298 & 298 \\
\hline Pressure & $\mathrm{atm}$ & 1 & 1 & 1 & 1 & 1 & 1 & 1 & 1 & 1 & 1 \\
\hline Vapor Frac & & 0 & 0 & 0 & 0 & 0 & 0 & 0 & 0 & 0 & 0 \\
\hline
\end{tabular}


Table G-1. Continued

\begin{tabular}{|c|c|c|c|c|c|c|c|c|c|c|c|c|}
\hline Component & Unit & DML-4 & MC-4 & BMOUT4 & $\begin{array}{l}\text { DML- } \\
5\end{array}$ & MC- & BMOUT5 & $\begin{array}{l}\text { DML- } \\
6\end{array}$ & $\begin{array}{l}\text { MC- } \\
6\end{array}$ & BMOUT6 & DML-7 & MC-7 \\
\hline $\begin{array}{l}\text { Overall Flow (moisture } \\
\text { and dry matter) }\end{array}$ & $\mathrm{kg} / \mathrm{hr}$ & 0 & 0 & 108,001 & 0 & 0 & 108,001 & 0 & 0 & 108,001 & 25 & 0 \\
\hline Moisture Flow & $\mathrm{kg} / \mathrm{hr}$ & 0 & 0 & 29,719 & 0 & 0 & 29,719 & 0 & 0 & 29,719 & 25 & 0 \\
\hline Total Flow (dry matter) & $\mathrm{kg} / \mathrm{hr}$ & 0 & 0 & 78,282 & 0 & 0 & 78,282 & 0 & 0 & 78,282 & 0 & 0 \\
\hline C6 & $\mathrm{kg} / \mathrm{hr}$ & 0 & 0 & 29,753 & 0 & 0 & 29,753 & 0 & 0 & 29,753 & 0 & 0 \\
\hline C5 & $\mathrm{kg} / \mathrm{hr}$ & 0 & 0 & 16,442 & 0 & 0 & 16,442 & 0 & 0 & 16,442 & 0 & 0 \\
\hline LIGNIN & $\mathrm{kg} / \mathrm{hr}$ & 0 & 0 & 12,457 & 0 & 0 & 12,457 & 0 & 0 & 12,457 & 0 & 0 \\
\hline ASH & $\mathrm{kg} / \mathrm{hr}$ & 0 & 0 & 5,768 & 0 & 0 & 5,768 & 0 & 0 & 5,768 & 0 & 0 \\
\hline PROTEIN & $\mathrm{kg} / \mathrm{hr}$ & 0 & 0 & 2,373 & 0 & 0 & 2,373 & 0 & 0 & 2,373 & 0 & 0 \\
\hline EXTRACTIVES & $\mathrm{kg} / \mathrm{hr}$ & 0 & 0 & 10,598 & 0 & 0 & 10,598 & 0 & 0 & 10,598 & 0 & 0 \\
\hline OTHERS & $\mathrm{kg} / \mathrm{hr}$ & 0 & 0 & 891 & 0 & 0 & 891 & 0 & 0 & 891 & 0 & 0 \\
\hline Temperature & K & 298 & 298 & 298 & 298 & 298 & 298 & 298 & 298 & 298 & 298 & 298 \\
\hline Pressure & atm & 1 & 1 & 1 & 1 & 1 & 1 & 1 & 1 & 1 & 1 & 1 \\
\hline Vapor Frac & & 0 & 0 & 0 & 0 & 0 & 0 & 0 & 0 & 0 & 0 & 0 \\
\hline
\end{tabular}


Table G-1. Continued

\begin{tabular}{|c|c|c|c|c|c|c|c|c|}
\hline Component & Unit & BMOUT7 & DML-8 & MC-8 & BMOUT8 & DML-9 & MC-9 & BMOUT9 \\
\hline $\begin{array}{l}\text { Overall Flow (moisture } \\
\text { and dry matter) }\end{array}$ & $\mathrm{kg} / \mathrm{hr}$ & 107,975 & 0 & 20,988 & 86,987 & 0 & 0 & 86,987 \\
\hline Moisture Flow & $\mathrm{kg} / \mathrm{hr}$ & 29,693 & 0 & 20,988 & 8,705 & 0 & 0 & 8,705 \\
\hline Total Flow (dry matter) & $\mathrm{kg} / \mathrm{hr}$ & 78,282 & 0 & 0 & 78,282 & 0 & 0 & 78,282 \\
\hline C6 & $\mathrm{kg} / \mathrm{hr}$ & 29,753 & 0 & 0 & 29,753 & 0 & 0 & 29,753 \\
\hline C5 & $\mathrm{kg} / \mathrm{hr}$ & 16,442 & 0 & 0 & 16,442 & 0 & 0 & 16,442 \\
\hline LIGNIN & $\mathrm{kg} / \mathrm{hr}$ & 12,457 & 0 & 0 & 12,457 & 0 & 0 & 12,457 \\
\hline ASH & $\mathrm{kg} / \mathrm{hr}$ & 5,768 & 0 & 0 & 5,768 & 0 & 0 & 5,768 \\
\hline PROTEIN & $\mathrm{kg} / \mathrm{hr}$ & 2,373 & 0 & 0 & 2,373 & 0 & 0 & 2,373 \\
\hline EXTRACTIVES & $\mathrm{kg} / \mathrm{hr}$ & 10,598 & 0 & 0 & 10,598 & 0 & 0 & 10,598 \\
\hline OTHERS & $\mathrm{kg} / \mathrm{hr}$ & 891 & 0 & 0 & 891 & 0 & 0 & 891 \\
\hline Temperature & K & 298 & 298 & 298 & 298 & 298 & 298 & 298 \\
\hline Pressure & $\mathrm{atm}$ & 1 & 1 & 1 & 1 & 1 & 1 & 1 \\
\hline Vapor Frac & & 0 & 0 & 0 & 0 & 0 & 0 & 0 \\
\hline
\end{tabular}




\section{APPENDIX H - Process Flow Diagrams and Mass Balances for Supply of Forest Residues to IDL - 2022 Projection}

High-level stream table information from Aspen Plus modeling output follows, for key streams associated with each process operation area. This is followed by high-level PFDs for the associated process areas. Space for stream tables was limited; below is a key to lumped components. As the stream table information focuses primarily on the high-level overall process and does not include every individual modeled stream within each process area, mass balance closure around a given unit area may not be $100 \%$.



Figure H-1. High-level flowsheet showing key process areas for the Indirect Liquefaction Pathway SOT.

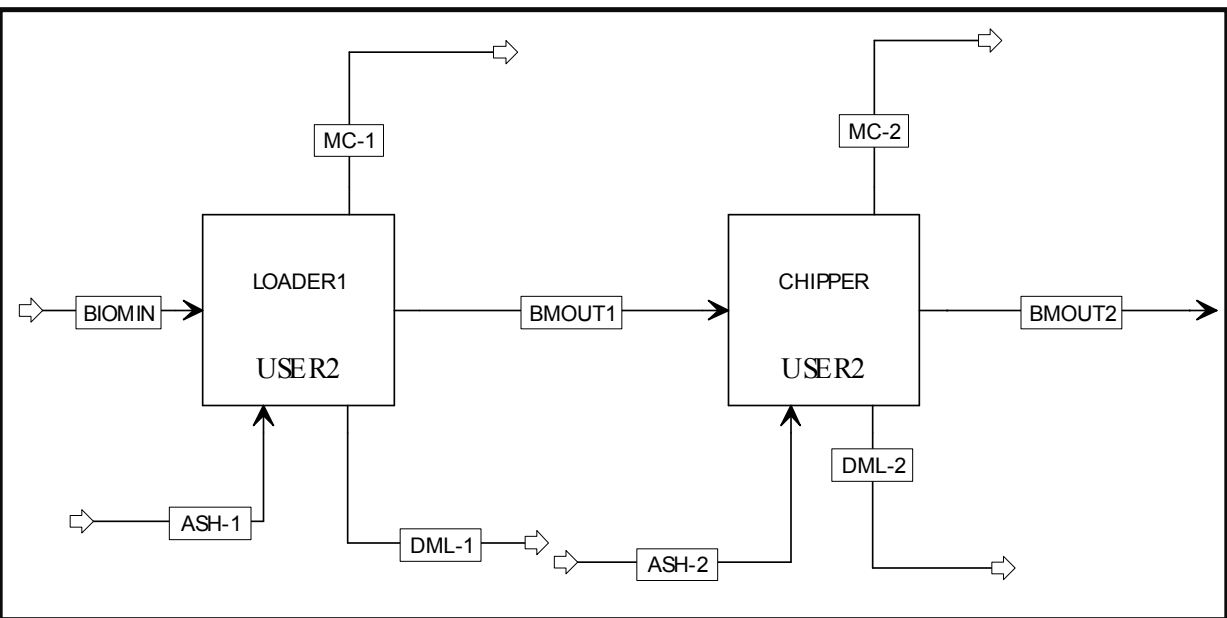

Figure H-2. Detailed process flow diagram for area H100 - Harvesting. 


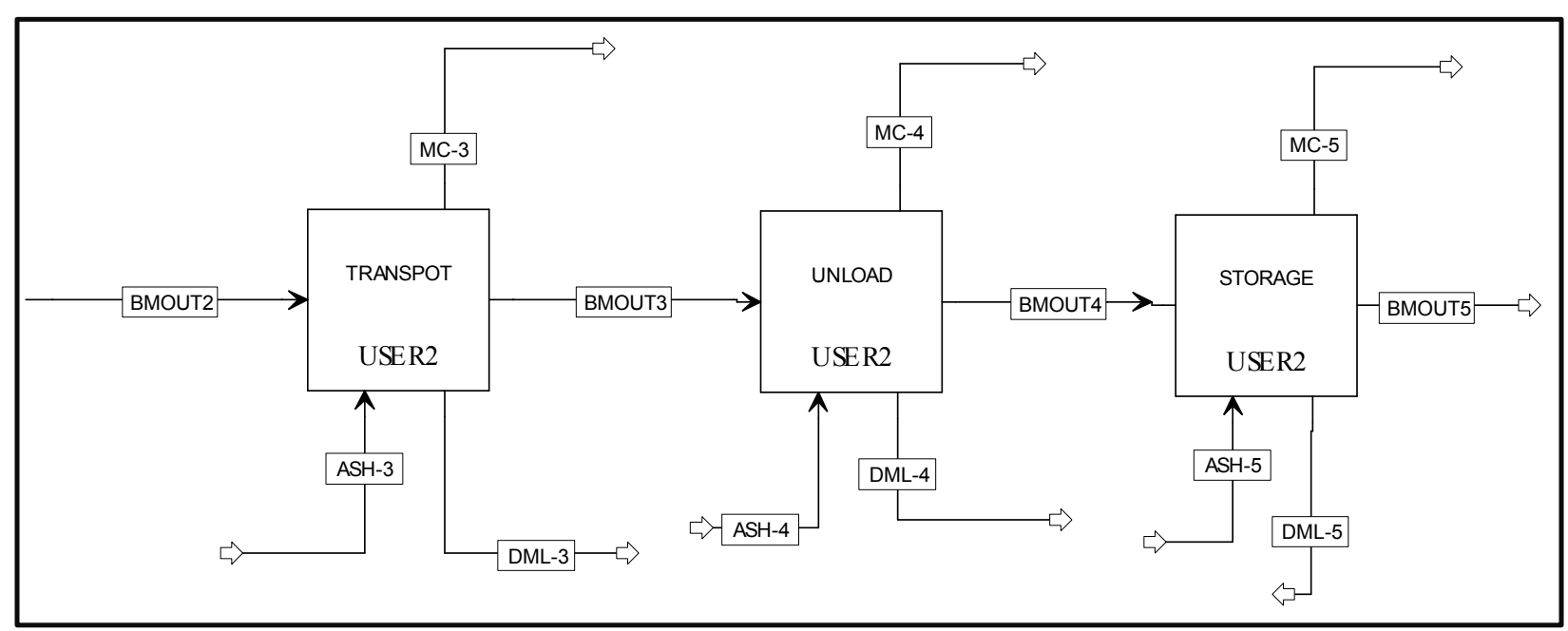

Figure H-3. Detailed process flow diagram for area H200 - Transport \& Storage.

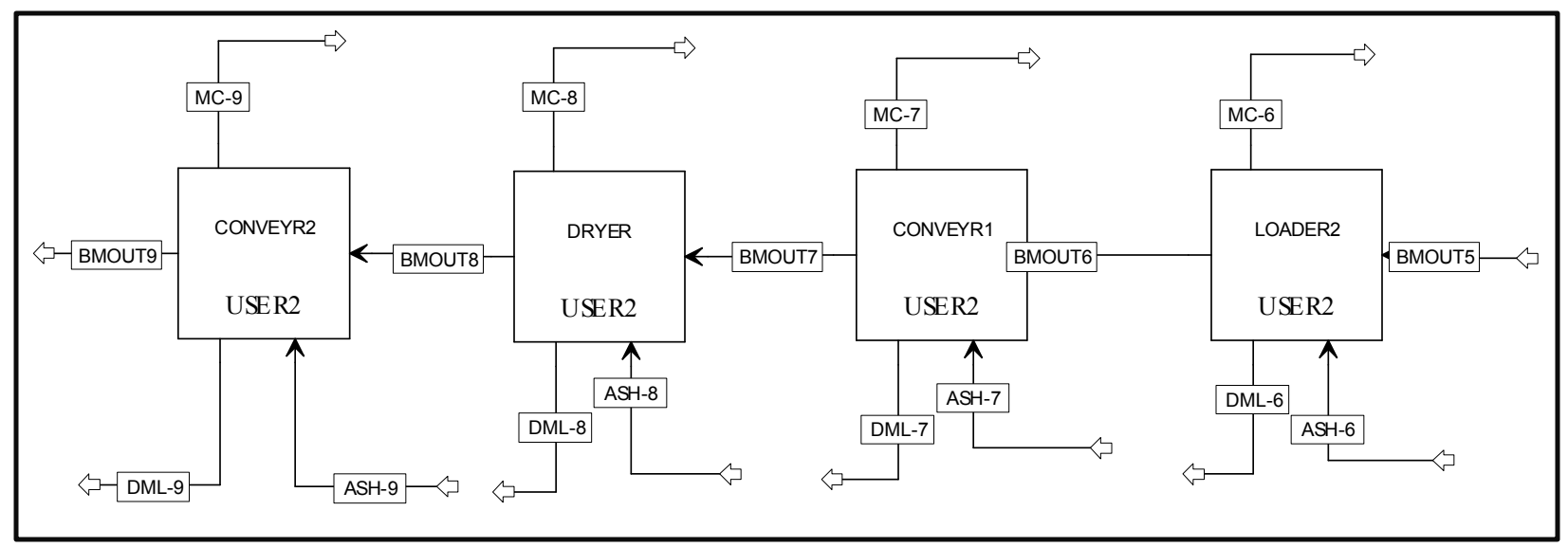

Figure H-4. Detailed process flow diagram for area H300-Preprocessing. 
MII Idaho National Laboratory

Milestone Completion

Report INL/EXT-18-

Table H-1. Aspen Plus mass balances for the Indirect Liquefaction Pathway 2022 Projection.

\begin{tabular}{|c|c|c|c|c|c|c|c|c|c|c|c|}
\hline Component & Unit & BIOMIN & DML-1 & MC-1 & BMOUT1 & DML-2 & MC-2 & BMOUT2 & DML-3 & MC-3 & BMOUT3 \\
\hline $\begin{array}{l}\text { Overall Flow (moisture } \\
\text { and dry matter) }\end{array}$ & $\mathrm{kg} / \mathrm{hr}$ & 117,718 & 0 & 0 & 117,718 & 4,121 & 5,597 & 108,001 & 0 & 0 & 108,001 \\
\hline Moisture Flow & $\mathrm{kg} / \mathrm{hr}$ & 35,316 & 0 & 0 & 35,316 & 0 & 5,597 & 29,719 & 0 & 0 & 29,719 \\
\hline Total Flow (dry matter) & $\mathrm{kg} / \mathrm{hr}$ & 82,403 & 0 & 0 & 82,403 & 4,121 & 0 & 78,282 & 0 & 0 & 78,282 \\
\hline C6 & $\mathrm{kg} / \mathrm{hr}$ & 30,513 & 0 & 0 & 30,513 & 760 & 0 & 29,753 & 0 & 0 & 29,753 \\
\hline C5 & $\mathrm{kg} / \mathrm{hr}$ & 17,634 & 0 & 0 & 17,634 & 1,192 & 0 & 16,442 & 0 & 0 & 16,442 \\
\hline LIGNIN & $\mathrm{kg} / \mathrm{hr}$ & 12,723 & 0 & 0 & 12,723 & 266 & 0 & 12,457 & 0 & 0 & 12,457 \\
\hline ASH & $\mathrm{kg} / \mathrm{hr}$ & 5,768 & 0 & 0 & 5,768 & 0 & 0 & 5,768 & 0 & 0 & 5,768 \\
\hline PROTEIN & $\mathrm{kg} / \mathrm{hr}$ & 2,497 & 0 & 0 & 2,497 & 123 & 0 & 2,373 & 0 & 0 & 2,373 \\
\hline EXTRACTIVES & $\mathrm{kg} / \mathrm{hr}$ & 11,833 & 0 & 0 & 11,833 & 1,235 & 0 & 10,598 & 0 & 0 & 10,598 \\
\hline OTHERS & $\mathrm{kg} / \mathrm{hr}$ & 1,434 & 0 & 0 & 1,434 & 543 & 0 & 891 & 0 & 0 & 891 \\
\hline Temperature & $\mathrm{K}$ & 298 & 298 & 298 & 298 & 298 & 298 & 298 & 298 & 298 & 298 \\
\hline Pressure & $\mathrm{atm}$ & 1 & 1 & 1 & 1 & 1 & 1 & 1 & 1 & 1 & 1 \\
\hline Vapor Frac & & 0 & 0 & 0 & 0 & 0 & 0 & 0 & 0 & 0 & 0 \\
\hline
\end{tabular}


Table H-1. Continued

\begin{tabular}{|c|c|c|c|c|c|c|c|c|c|c|c|c|}
\hline Component & Unit & DML-4 & MC-4 & BMOUT4 & $\begin{array}{l}\text { DML- } \\
5\end{array}$ & MC- & BMOUT5 & $\begin{array}{l}\text { DML- } \\
6\end{array}$ & $\begin{array}{l}\text { MC- } \\
6\end{array}$ & BMOUT6 & DML-7 & MC-7 \\
\hline $\begin{array}{l}\text { Overall Flow (moisture } \\
\text { and dry matter) }\end{array}$ & $\mathrm{kg} / \mathrm{hr}$ & 0 & 0 & 108,001 & 0 & 0 & 108,001 & 0 & 0 & 108,001 & 25 & 0 \\
\hline Moisture Flow & $\mathrm{kg} / \mathrm{hr}$ & 0 & 0 & 29,719 & 0 & 0 & 29,719 & 0 & 0 & 29,719 & 25 & 0 \\
\hline Total Flow (dry matter) & $\mathrm{kg} / \mathrm{hr}$ & 0 & 0 & 78,282 & 0 & 0 & 78,282 & 0 & 0 & 78,282 & 0 & 0 \\
\hline C6 & $\mathrm{kg} / \mathrm{hr}$ & 0 & 0 & 29,753 & 0 & 0 & 29,753 & 0 & 0 & 29,753 & 0 & 0 \\
\hline C5 & $\mathrm{kg} / \mathrm{hr}$ & 0 & 0 & 16,442 & 0 & 0 & 16,442 & 0 & 0 & 16,442 & 0 & 0 \\
\hline LIGNIN & $\mathrm{kg} / \mathrm{hr}$ & 0 & 0 & 12,457 & 0 & 0 & 12,457 & 0 & 0 & 12,457 & 0 & 0 \\
\hline ASH & $\mathrm{kg} / \mathrm{hr}$ & 0 & 0 & 5,768 & 0 & 0 & 5,768 & 0 & 0 & 5,768 & 0 & 0 \\
\hline PROTEIN & $\mathrm{kg} / \mathrm{hr}$ & 0 & 0 & 2,373 & 0 & 0 & 2,373 & 0 & 0 & 2,373 & 0 & 0 \\
\hline EXTRACTIVES & $\mathrm{kg} / \mathrm{hr}$ & 0 & 0 & 10,598 & 0 & 0 & 10,598 & 0 & 0 & 10,598 & 0 & 0 \\
\hline OTHERS & $\mathrm{kg} / \mathrm{hr}$ & 0 & 0 & 891 & 0 & 0 & 891 & 0 & 0 & 891 & 0 & 0 \\
\hline Temperature & K & 298 & 298 & 298 & 298 & 298 & 298 & 298 & 298 & 298 & 298 & 298 \\
\hline Pressure & atm & 1 & 1 & 1 & 1 & 1 & 1 & 1 & 1 & 1 & 1 & 1 \\
\hline Vapor Frac & & 0 & 0 & 0 & 0 & 0 & 0 & 0 & 0 & 0 & 0 & 0 \\
\hline
\end{tabular}


Table H-1. Continued

\begin{tabular}{|c|c|c|c|c|c|c|c|c|}
\hline Component & Unit & BMOUT7 & DML-8 & MC-8 & BMOUT8 & DML-9 & MC-9 & BMOUT9 \\
\hline $\begin{array}{l}\text { Overall Flow (moisture } \\
\text { and dry matter) }\end{array}$ & $\mathrm{kg} / \mathrm{hr}$ & 107,975 & 0 & 20,988 & 86,987 & 0 & 0 & 86,987 \\
\hline Moisture Flow & $\mathrm{kg} / \mathrm{hr}$ & 29,693 & 0 & 20,988 & 8,705 & 0 & 0 & 8,705 \\
\hline Total Flow (dry matter) & $\mathrm{kg} / \mathrm{hr}$ & 78,282 & 0 & 0 & 78,282 & 0 & 0 & 78,282 \\
\hline C6 & $\mathrm{kg} / \mathrm{hr}$ & 29,753 & 0 & 0 & 29,753 & 0 & 0 & 29,753 \\
\hline C5 & $\mathrm{kg} / \mathrm{hr}$ & 16,442 & 0 & 0 & 16,442 & 0 & 0 & 16,442 \\
\hline LIGNIN & $\mathrm{kg} / \mathrm{hr}$ & 12,457 & 0 & 0 & 12,457 & 0 & 0 & 12,457 \\
\hline ASH & $\mathrm{kg} / \mathrm{hr}$ & 5,768 & 0 & 0 & 5,768 & 0 & 0 & 5,768 \\
\hline PROTEIN & $\mathrm{kg} / \mathrm{hr}$ & 2,373 & 0 & 0 & 2,373 & 0 & 0 & 2,373 \\
\hline EXTRACTIVES & $\mathrm{kg} / \mathrm{hr}$ & 10,598 & 0 & 0 & 10,598 & 0 & 0 & 10,598 \\
\hline OTHERS & $\mathrm{kg} / \mathrm{hr}$ & 891 & 0 & 0 & 891 & 0 & 0 & 891 \\
\hline Temperature & $\mathrm{K}$ & 298 & 298 & 298 & 298 & 298 & 298 & 298 \\
\hline Pressure & atm & 1 & 1 & 1 & 1 & 1 & 1 & 1 \\
\hline Vapor Frac & & 0 & 0 & 0 & 0 & 0 & 0 & 0 \\
\hline
\end{tabular}




\section{APPENDIX I - Process Flow Diagrams and Mass Balances for Supply of Clean Pine to CFP - 2018 SOT}

High-level stream table information from Aspen Plus modeling output follows, for key streams associated with each process operation area. This is followed by high-level PFDs for the associated process areas. Space for stream tables was limited; below is a key to lumped components. As the stream table information focuses primarily on the high-level overall process and does not include every individual modeled stream within each process area, mass balance closure around a given unit area may not be $100 \%$.

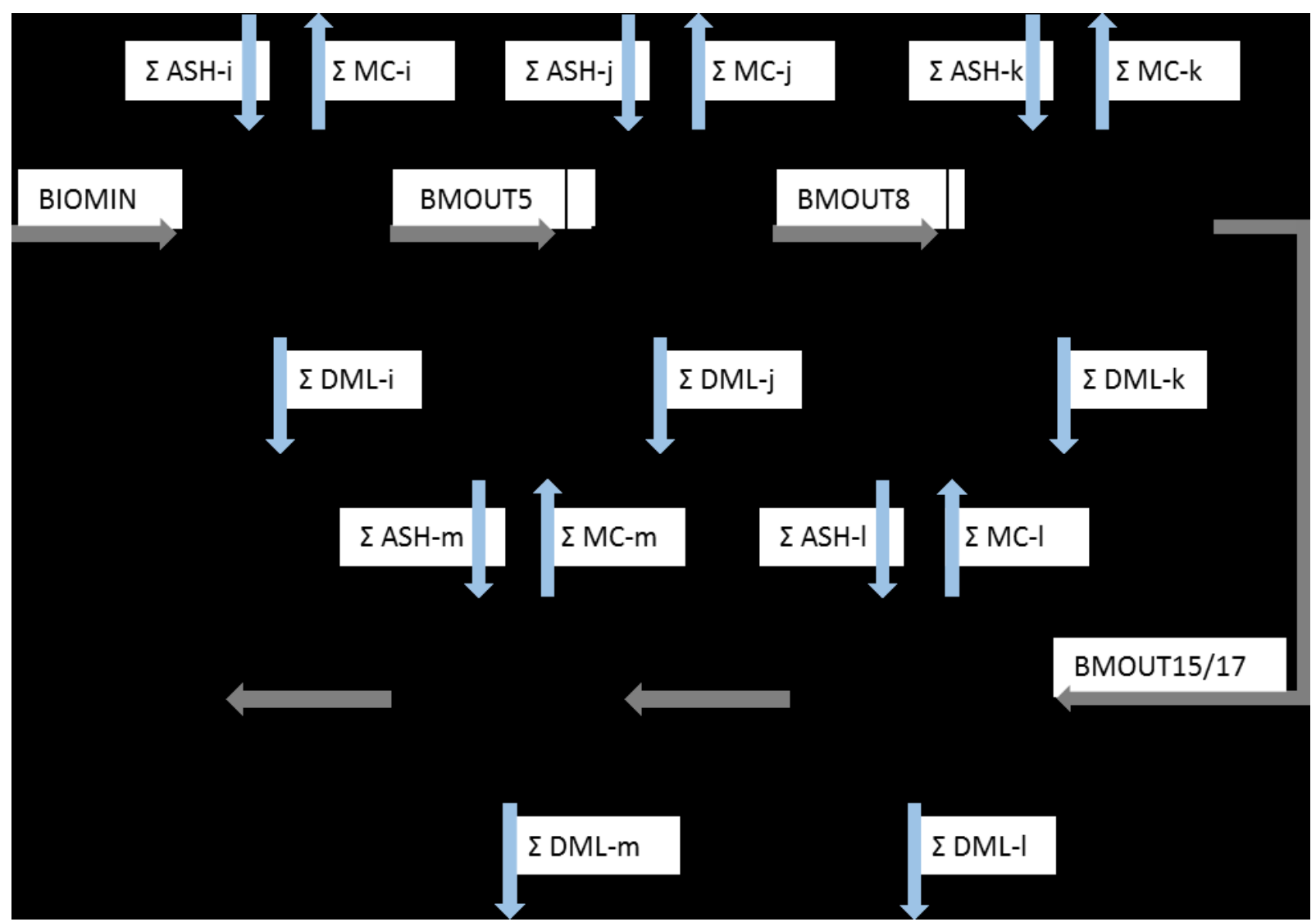

Figure I-1. High-level flowsheet showing key process areas for the Catalytic Fast Pyrolysis-Hydrotreating Pathway SOT. 

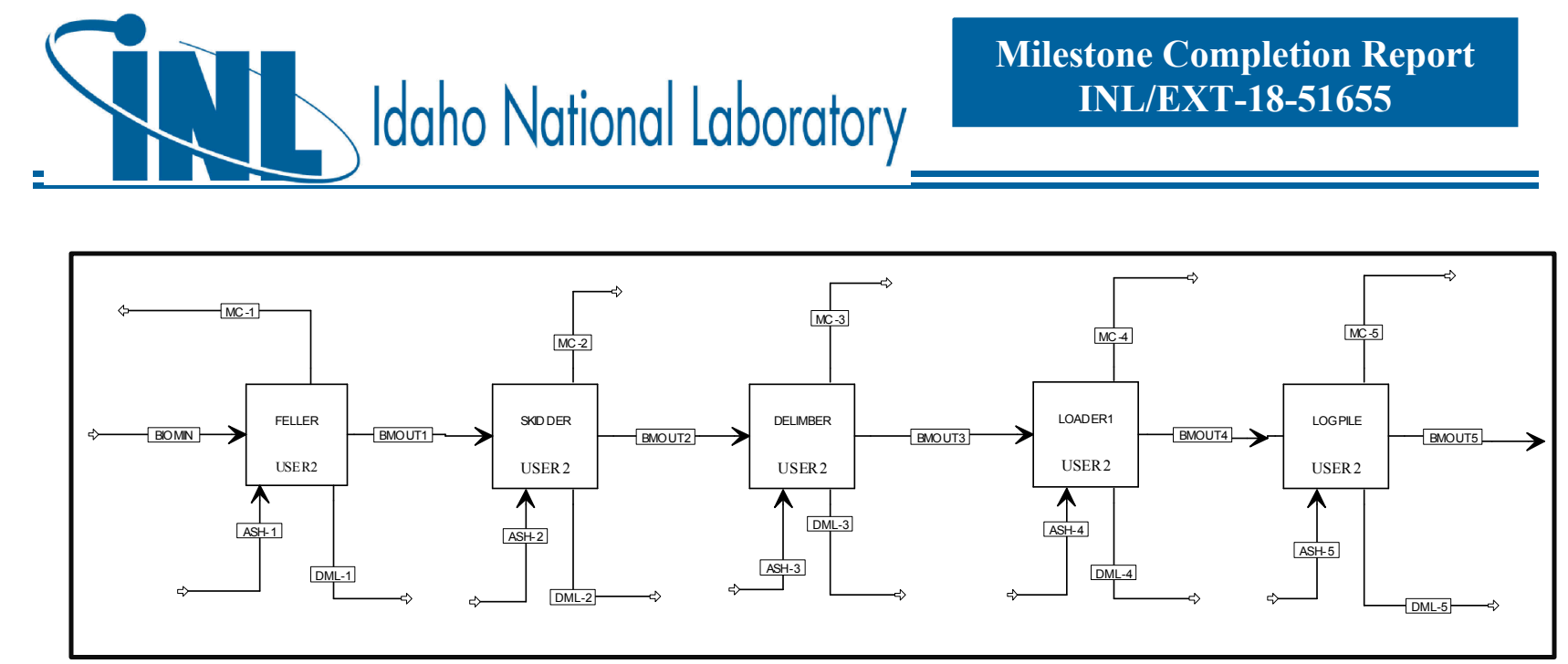

Figure I-2. Detailed process flow diagram for area I100 - Harvesting.

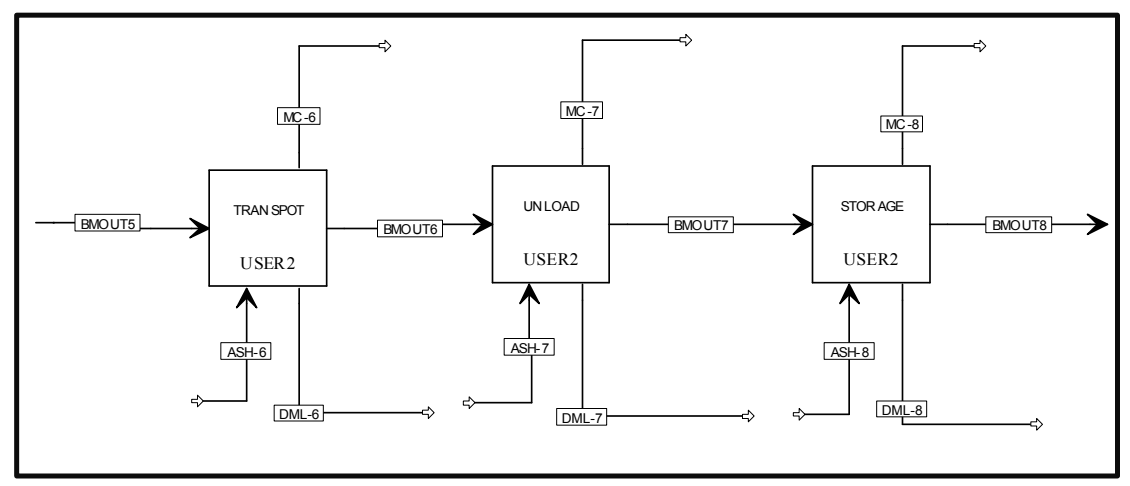

Figure I-3. Detailed process flow diagram for area I200 - Transport \& Storage. 

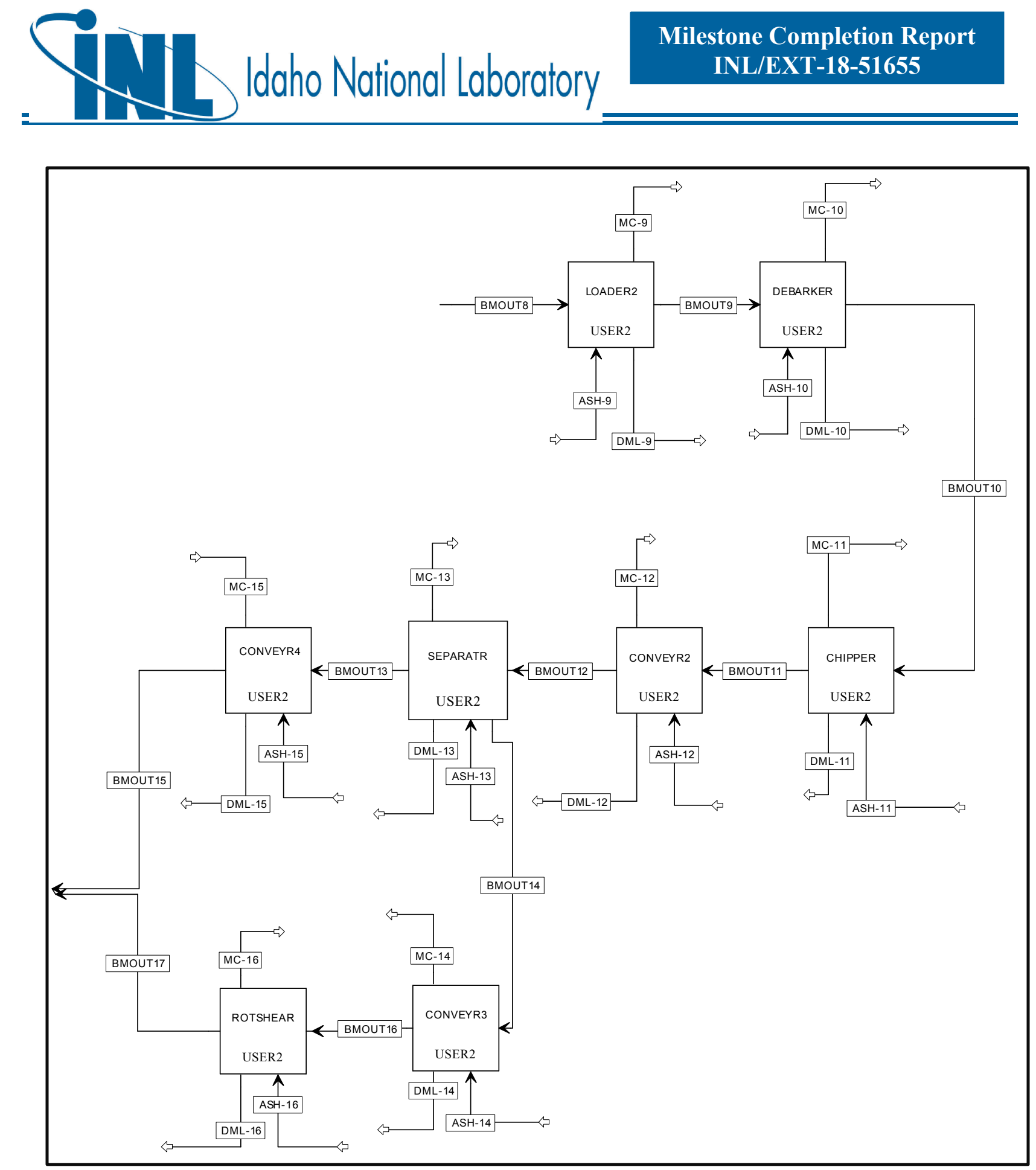

Figure I-4. Detailed process flow diagram for area I300 - Preprocessing - Size Reduction. 

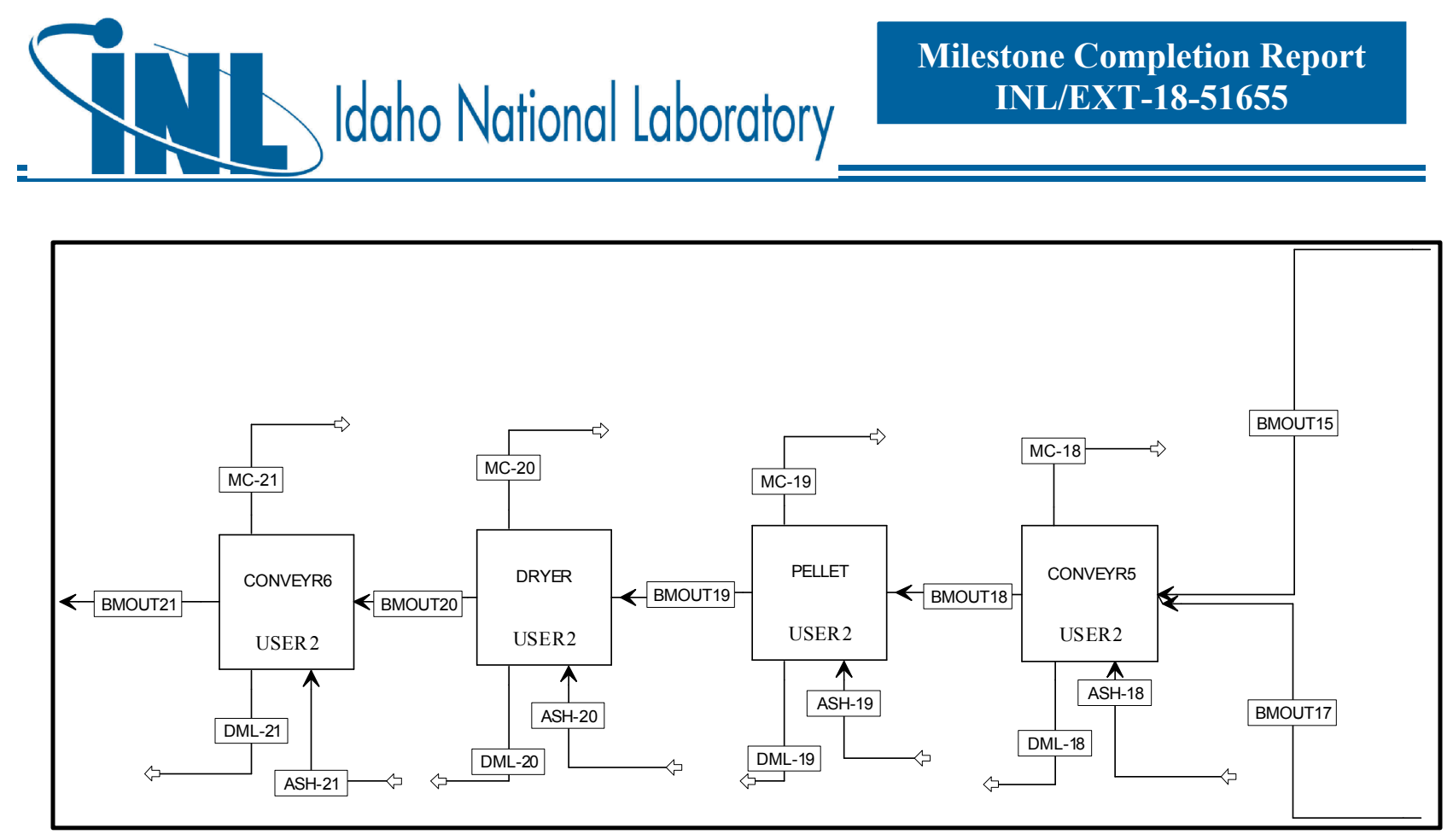

Figure I-5. Detailed process flow diagram for area I400 - Preprocessing - Pelleting.

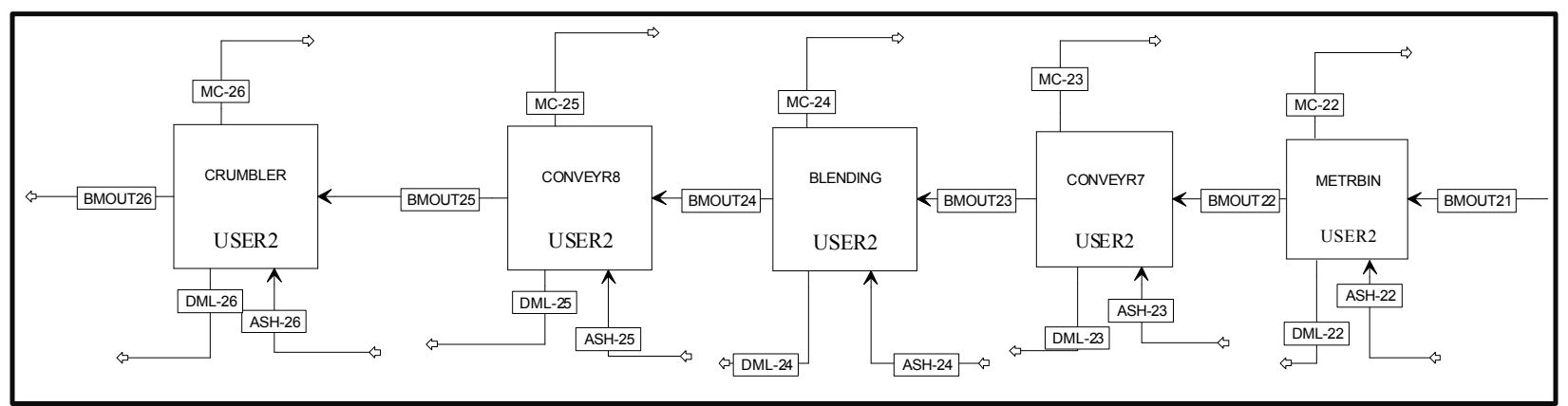

Figure I-6. Detailed process flow diagram for area I500 - Feeding. 
Table I-1. Aspen Plus mass balances for the Catalytic Fast Pyrolysis-Hydrotreating Pathway SOT.

\begin{tabular}{|c|c|c|c|c|c|c|c|c|c|c|c|c|c|}
\hline Component & unit & BIOMIN & DML-1 & MC-1 & BMOUT1 & DML-2 & MC-2 & BMOUT2 & $\begin{array}{l}\text { DML- } \\
3\end{array}$ & MC-3 & BMOUT3 & $\begin{array}{l}\text { DML- } \\
4\end{array}$ & MC- \\
\hline $\begin{array}{l}\text { Overall Flow } \\
\text { (moisture and dry }\end{array}$ & $\mathrm{kg} / \mathrm{hr}$ & 158,148 & 0 & 1 & 158,147 & 0 & 0 & 158,147 & 3,044 & 2,432 & 152,670 & 0 & 0 \\
\hline Moisture Flow & $\mathrm{kg} / \mathrm{hr}$ & 71,167 & 0 & 1 & 71,166 & 0 & 0 & 71,166 & 0 & 2,432 & 68,734 & 0 & 0 \\
\hline $\begin{array}{l}\text { Total Flow (dry } \\
\text { matter) }\end{array}$ & $\mathrm{kg} / \mathrm{hr}$ & 86,981 & 0 & 0 & 86,981 & 0 & 0 & 86,981 & 3,044 & 0 & 83,936 & 0 & 0 \\
\hline C6 & $\mathrm{kg} / \mathrm{hr}$ & 32,209 & 0 & 0 & 32,209 & 0 & 0 & 32,209 & 562 & 0 & 31,647 & 0 & 0 \\
\hline C5 & $\mathrm{kg} / \mathrm{hr}$ & 18,613 & 0 & 0 & 18,613 & 0 & 0 & 18,613 & 881 & 0 & 17,734 & 0 & 0 \\
\hline LIGNIN & $\mathrm{kg} / \mathrm{hr}$ & 13,430 & 0 & 0 & 13,430 & 0 & 0 & 13,430 & 197 & 0 & 13,234 & 0 & 0 \\
\hline ASH & $\mathrm{kg} / \mathrm{hr}$ & 6,089 & 0 & 0 & 6,089 & 0 & 0 & 6,089 & 0 & 0 & 6,089 & 0 & 0 \\
\hline PROTEIN & $\mathrm{kg} / \mathrm{hr}$ & 2,635 & 0 & 0 & 2,635 & 0 & 0 & 2,635 & 92 & 0 & 2,544 & 0 & 0 \\
\hline EXTRACTIVES & $\mathrm{kg} / \mathrm{hr}$ & 12,491 & 0 & 0 & 12,491 & 0 & 0 & 12,491 & 913 & 0 & 11,577 & 0 & 0 \\
\hline OTHERS & $\mathrm{kg} / \mathrm{hr}$ & 1,513 & 0 & 0 & 1,513 & 0 & 0 & 1,513 & 401 & 0 & 1,112 & 0 & 0 \\
\hline Temperature & K & 298 & 298 & 298 & 298 & 298 & 298 & 298 & 298 & 298 & 298 & 298 & 298 \\
\hline Pressure & $\mathrm{atm}$ & 1 & 1 & 1 & 1 & 1 & 1 & 1 & 1 & 1 & 1 & 1 & 1 \\
\hline Vapor Frac & & 0 & 0 & 0 & 0 & 0 & 0 & 0 & 0 & 0 & 0 & 0 & 0 \\
\hline
\end{tabular}


Milestone Completion Report

INL/EXT-18-51655

Table I-1. Continued

\begin{tabular}{|c|c|c|c|c|c|c|c|c|c|c|c|c|}
\hline Component & unit & BMOUT4 & DML-5 & MC-5 & BMOUT5 & DML-6 & MC-6 & BMOUT6 & $\begin{array}{l}\text { DML- } \\
7\end{array}$ & MC-7 & BMOUT7 & $\begin{array}{l}\text { DML- } \\
8\end{array}$ \\
\hline $\begin{array}{l}\text { Overall Flow } \\
\text { (moisture and dry }\end{array}$ & $\mathrm{kg} / \mathrm{hr}$ & 152,670 & 1,679 & 41,291 & 109,700 & 0 & 0 & 109,700 & 0 & 0 & 109,700 & 0 \\
\hline Moisture Flow & $\mathrm{kg} / \mathrm{hr}$ & 68,734 & 0 & 41,291 & 27,442 & 0 & 0 & 27,442 & 0 & 0 & 27,442 & 0 \\
\hline $\begin{array}{l}\text { Total Flow (dry } \\
\text { matter) }\end{array}$ & $\mathrm{kg} / \mathrm{hr}$ & 83,936 & 1,679 & 0 & 82,258 & 0 & 0 & 82,258 & 0 & 0 & 82,258 & 0 \\
\hline C6 & $\mathrm{kg} / \mathrm{hr}$ & 31,647 & 310 & 0 & 31,337 & 0 & 0 & 31,337 & 0 & 0 & 31,337 & 0 \\
\hline C5 & $\mathrm{kg} / \mathrm{hr}$ & 17,734 & 486 & 0 & 17,248 & 0 & 0 & 17,248 & 0 & 0 & 17,248 & 0 \\
\hline LIGNIN & $\mathrm{kg} / \mathrm{hr}$ & 13,234 & 108 & 0 & 13,125 & 0 & 0 & 13,125 & 0 & 0 & 13,125 & 0 \\
\hline ASH & $\mathrm{kg} / \mathrm{hr}$ & 6,089 & 0 & 0 & 6,089 & 0 & 0 & 6,089 & 0 & 0 & 6,089 & 0 \\
\hline PROTEIN & $\mathrm{kg} / \mathrm{hr}$ & 2,544 & 51 & 0 & 2,494 & 0 & 0 & 2,494 & 0 & 0 & 2,494 & 0 \\
\hline EXTRACTIVES & $\mathrm{kg} / \mathrm{hr}$ & 11,577 & 504 & 0 & 11,074 & 0 & 0 & 11,074 & 0 & 0 & 11,074 & 0 \\
\hline OTHERS & $\mathrm{kg} / \mathrm{hr}$ & 1,112 & 221 & 0 & 891 & 0 & 0 & 891 & 0 & 0 & 891 & 0 \\
\hline Temperature & K & 298 & 298 & 298 & 298 & 298 & 298 & 298 & 298 & 298 & 298 & 298 \\
\hline Pressure & atm & 1 & 1 & 1 & 1 & 1 & 1 & 1 & 1 & 1 & 1 & 1 \\
\hline Vapor Frac & & 0 & 0 & 0 & 0 & 0 & 0 & 0 & 0 & 0 & 0 & 0 \\
\hline
\end{tabular}

102 
Table I-1. Continued

\begin{tabular}{|c|c|c|c|c|c|c|c|c|c|c|c|c|}
\hline Component & unit & MC-8 & BMOUT8 & DML-9 & MC-9 & BMOUT9 & DML-10 & $\begin{array}{c}\text { MC- } \\
10\end{array}$ & BMOUT10 & $\begin{array}{l}\text { DML- } \\
11\end{array}$ & MC- & BMOUT11 \\
\hline $\begin{array}{l}\text { Overall Flow } \\
\text { (moisture and dry }\end{array}$ & $\mathrm{kg} / \mathrm{hr}$ & 0 & 109,700 & 0 & 0 & 109,700 & 1,646 & 0 & 108,054 & 1,620 & 3,959 & 102,475 \\
\hline Moisture Flow & $\mathrm{kg} / \mathrm{hr}$ & 0 & 27,442 & 0 & 0 & 27,442 & 411 & 0 & 27,031 & 0 & 3,959 & 23,072 \\
\hline $\begin{array}{l}\text { Total Flow (dry } \\
\text { matter) }\end{array}$ & $\mathrm{kg} / \mathrm{hr}$ & 0 & 82,258 & 0 & 0 & 82,258 & 1,234 & 0 & 81,023 & 1,620 & 0 & 79,403 \\
\hline C6 & $\mathrm{kg} / \mathrm{hr}$ & 0 & 31,337 & 0 & 0 & 31,337 & 227 & 0 & 31,110 & 449 & 0 & 30,660 \\
\hline C5 & $\mathrm{kg} / \mathrm{hr}$ & 0 & 17,248 & 0 & 0 & 17,248 & 357 & 0 & 16,891 & 252 & 0 & 16,639 \\
\hline LIGNIN & $\mathrm{kg} / \mathrm{hr}$ & 0 & 13,125 & 0 & 0 & 13,125 & 80 & 0 & 13,045 & 314 & 0 & 12,732 \\
\hline ASH & $\mathrm{kg} / \mathrm{hr}$ & 0 & 6,089 & 0 & 0 & 6,089 & 0 & 0 & 6,089 & 405 & 0 & 5,683 \\
\hline PROTEIN & $\mathrm{kg} / \mathrm{hr}$ & 0 & 2,494 & 0 & 0 & 2,494 & 37 & 0 & 2,457 & 0 & 0 & 2,457 \\
\hline EXTRACTIVES & $\mathrm{kg} / \mathrm{hr}$ & 0 & 11,074 & 0 & 0 & 11,074 & 370 & 0 & 10,704 & 200 & 0 & 10,504 \\
\hline OTHERS & $\mathrm{kg} / \mathrm{hr}$ & 0 & 891 & 0 & 0 & 891 & 162 & 0 & 729 & 0 & 0 & 729 \\
\hline Temperature & K & 298 & 298 & 298 & 298 & 298 & 298 & 298 & 298 & 298 & 298 & 298 \\
\hline Pressure & $\mathrm{atm}$ & 1 & 1 & 1 & 1 & 1 & 1 & 1 & 1 & 1 & 1 & 1 \\
\hline Vapor Frac & & 0 & 0 & 0 & 0 & 0 & 0 & 0 & 0 & 0 & 0 & 0 \\
\hline
\end{tabular}


Milestone Completion Report

INL/EXT-18-51655

Table I-1. Continued

\begin{tabular}{|c|c|c|c|c|c|c|c|c|c|c|c|c|}
\hline Component & unit & DML-12 & MC-12 & BMOUT12 & DML-13 & MC-13 & BMOUT13 & BMOUT14 & $\begin{array}{l}\text { DML- } \\
14\end{array}$ & MC-14 & BMOUT16 & $\begin{array}{l}\text { DML- } \\
15\end{array}$ \\
\hline $\begin{array}{l}\text { Overall Flow } \\
\text { (moisture and dry }\end{array}$ & $\mathrm{kg} / \mathrm{hr}$ & 0 & 0 & 102,475 & 0 & 0 & 15,371 & 87,104 & 0 & 0 & 87,104 & 0 \\
\hline Moisture Flow & $\mathrm{kg} / \mathrm{hr}$ & 0 & 0 & 23,072 & 0 & 0 & 3,461 & 19,611 & 0 & 0 & 19,611 & 0 \\
\hline $\begin{array}{l}\text { Total Flow (dry } \\
\text { matter) }\end{array}$ & $\mathrm{kg} / \mathrm{hr}$ & 0 & 0 & 79,403 & 0 & 0 & 11,911 & 67,493 & 0 & 0 & 67,493 & 0 \\
\hline C6 & $\mathrm{kg} / \mathrm{hr}$ & 0 & 0 & 30,660 & 0 & 0 & 4,599 & 26,061 & 0 & 0 & 26,061 & 0 \\
\hline C5 & $\mathrm{kg} / \mathrm{hr}$ & 0 & 0 & 16,639 & 0 & 0 & 2,496 & 14,143 & 0 & 0 & 14,143 & 0 \\
\hline LIGNIN & $\mathrm{kg} / \mathrm{hr}$ & 0 & 0 & 12,732 & 0 & 0 & 1,909 & 10,822 & 0 & 0 & 10,822 & 0 \\
\hline ASH & $\mathrm{kg} / \mathrm{hr}$ & 0 & 0 & 5,683 & 0 & 0 & 853 & 4,831 & 0 & 0 & 4,831 & 0 \\
\hline PROTEIN & $\mathrm{kg} / \mathrm{hr}$ & 0 & 0 & 2,457 & 0 & 0 & 369 & 2,088 & 0 & 0 & 2,088 & 0 \\
\hline EXTRACTIVES & $\mathrm{kg} / \mathrm{hr}$ & 0 & 0 & 10,504 & 0 & 0 & 1,576 & 8,928 & 0 & 0 & 8,928 & 0 \\
\hline OTHERS & $\mathrm{kg} / \mathrm{hr}$ & 0 & 0 & 729 & 0 & 0 & 110 & 619 & 0 & 0 & 619 & 0 \\
\hline Temperature & K & 298 & 298 & 298 & 298 & 298 & 298 & 298 & 298 & 298 & 298 & 298 \\
\hline Pressure & $\mathrm{atm}$ & 1 & 1 & 1 & 1 & 1 & 1 & 1 & 1 & 1 & 1 & 1 \\
\hline Vapor Frac & & 0 & 0 & 0 & 0 & 0 & 0 & 0 & 0 & 0 & 0 & 0 \\
\hline
\end{tabular}


Milestone Completion Report

INL/EXT-18-51655

Table I-1. Continued

\begin{tabular}{|c|c|c|c|c|c|c|c|c|c|c|c|c|}
\hline Component & unit & MC-15 & BMOUT15 & DML-16 & MC-16 & BMOUT17 & DML-18 & $\begin{array}{l}\text { MC- } \\
18\end{array}$ & BMOUT1 & $\begin{array}{l}\text { DML- } \\
19\end{array}$ & $\begin{array}{l}\text { MC- } \\
19\end{array}$ & BMOUT1 \\
\hline $\begin{array}{l}\text { Overall Flow } \\
\text { (moisture and dry }\end{array}$ & $\mathrm{kg} / \mathrm{hr}$ & 15,371 & 87,104 & 0 & 0 & 87,104 & 0 & 0 & 574 & $\begin{array}{r}14,79 \\
8\end{array}$ & 675 & 3,412 \\
\hline Moisture Flow & $\mathrm{kg} / \mathrm{hr}$ & 3,461 & 19,611 & 0 & 0 & 19,611 & 0 & 0 & 574 & 2,887 & 0 & 3,412 \\
\hline $\begin{array}{l}\text { Total Flow (dry } \\
\text { matter) }\end{array}$ & $\mathrm{kg} / \mathrm{hr}$ & 11,911 & 67,493 & 0 & 0 & 67,493 & 0 & 0 & 0 & $\begin{array}{r}11,91 \\
1\end{array}$ & 675 & 0 \\
\hline C6 & $\mathrm{kg} / \mathrm{hr}$ & 4,599 & 26,061 & 0 & 0 & 26,061 & 0 & 0 & 0 & 4,599 & 187 & 0 \\
\hline C5 & $\mathrm{kg} / \mathrm{hr}$ & 2,496 & 14,143 & 0 & 0 & 14,143 & 0 & 0 & 0 & 2,496 & 105 & 0 \\
\hline LIGNIN & $\mathrm{kg} / \mathrm{hr}$ & 1,909 & 10,822 & 0 & 0 & 10,822 & 0 & 0 & 0 & 1,909 & 131 & 0 \\
\hline ASH & $\mathrm{kg} / \mathrm{hr}$ & 853 & 4,831 & 0 & 0 & 4,831 & 0 & 0 & 0 & 853 & 169 & 0 \\
\hline PROTEIN & $\mathrm{kg} / \mathrm{hr}$ & 369 & 2,088 & 0 & 0 & 2,088 & 0 & 0 & 0 & 369 & 0 & 0 \\
\hline EXTRACTIVES & $\mathrm{kg} / \mathrm{hr}$ & 1,576 & 8,928 & 0 & 0 & 8,928 & 0 & 0 & 0 & 1,576 & 83 & 0 \\
\hline OTHERS & $\mathrm{kg} / \mathrm{hr}$ & 110 & 619 & 0 & 0 & 619 & 0 & 0 & 0 & 110 & 0 & 0 \\
\hline Temperature & K & 298 & 298 & 298 & 298 & 298 & 298 & 298 & 298 & 298 & 298 & 298 \\
\hline Pressure & $\mathrm{atm}$ & 1 & 1 & 1 & 1 & 1 & 1 & 1 & 1 & 1 & 1 & 1 \\
\hline Vapor Frac & & 0 & 0 & 0 & 0 & 0 & 0 & 0 & 0 & 0 & 0 & 0 \\
\hline
\end{tabular}




\section{Table I-1. Continued}

\begin{tabular}{|c|c|c|c|c|c|c|c|c|c|c|c|c|}
\hline Component & unit & DML-20 & MC-20 & BMOUT20 & DML-21 & MC-21 & BMOUT21 & $\begin{array}{l}\text { DML- } \\
22\end{array}$ & $\begin{array}{l}\text { MC- } \\
22\end{array}$ & BMOUT22 & $\begin{array}{l}\text { DML- } \\
23\end{array}$ & $\begin{array}{l}\text { MC- } \\
23\end{array}$ \\
\hline $\begin{array}{l}\text { Overall Flow } \\
\text { (moisture and dry }\end{array}$ & $\mathrm{kg} / \mathrm{hr}$ & 0 & 5,150 & 87,483 & 0 & 0 & 87,483 & 0 & 0 & 87,483 & 0 & 0 \\
\hline Moisture Flow & $\mathrm{kg} / \mathrm{hr}$ & 0 & 5,150 & 8,755 & 0 & 0 & 8,755 & 0 & 0 & 8,755 & 0 & 0 \\
\hline $\begin{array}{l}\text { Total Flow (dry } \\
\text { matter) }\end{array}$ & $\mathrm{kg} / \mathrm{hr}$ & 0 & 0 & 78,728 & 0 & 0 & 78,728 & 0 & 0 & 78,728 & 0 & 0 \\
\hline C6 & $\mathrm{kg} / \mathrm{hr}$ & 0 & 0 & 30,474 & 0 & 0 & 30,474 & 0 & 0 & 30,474 & 0 & 0 \\
\hline C5 & $\mathrm{kg} / \mathrm{hr}$ & 0 & 0 & 16,534 & 0 & 0 & 16,534 & 0 & 0 & 16,534 & 0 & 0 \\
\hline LIGNIN & $\mathrm{kg} / \mathrm{hr}$ & 0 & 0 & 12,601 & 0 & 0 & 12,601 & 0 & 0 & 12,601 & 0 & 0 \\
\hline ASH & $\mathrm{kg} / \mathrm{hr}$ & 0 & 0 & 5,515 & 0 & 0 & 5,515 & 0 & 0 & 5,515 & 0 & 0 \\
\hline PROTEIN & $\mathrm{kg} / \mathrm{hr}$ & 0 & 0 & 2,457 & 0 & 0 & 2,457 & 0 & 0 & 2,457 & 0 & 0 \\
\hline EXTRACTIVES & $\mathrm{kg} / \mathrm{hr}$ & 0 & 0 & 10,421 & 0 & 0 & 10,421 & 0 & 0 & 10,421 & 0 & 0 \\
\hline OTHERS & $\mathrm{kg} / \mathrm{hr}$ & 0 & 0 & 729 & 0 & 0 & 729 & 0 & 0 & 729 & 0 & 0 \\
\hline Temperature & K & 298 & 298 & 298 & 298 & 298 & 298 & 298 & 298 & 298 & 298 & 298 \\
\hline Pressure & $\mathrm{atm}$ & 1 & 1 & 1 & 1 & 1 & 1 & 1 & 1 & 1 & 1 & 1 \\
\hline Vapor Frac & & 0 & 0 & 0 & 0 & 0 & 0 & 0 & 0 & 0 & 0 & 0 \\
\hline
\end{tabular}


Table I-1. Continued

\begin{tabular}{|c|c|c|c|c|c|c|c|c|c|c|c|}
\hline Component & unit & BMOUT23 & $\begin{array}{l}\text { DML- } \\
24\end{array}$ & MC-24 & BMOUT24 & DML-25 & MC-25 & BMOUT25 & $\begin{array}{l}\text { DML- } \\
26\end{array}$ & $\begin{array}{l}\text { MC- } \\
26\end{array}$ & BMOUT2 \\
\hline $\begin{array}{l}\text { Overall Flow } \\
\text { (moisture and dry }\end{array}$ & $\mathrm{kg} / \mathrm{hr}$ & 87,483 & 0 & 0 & 87,483 & 0 & 0 & 87,483 & 0 & 0 & 87,483 \\
\hline Moisture Flow & $\mathrm{kg} / \mathrm{hr}$ & 8,755 & 0 & 0 & 8,755 & 0 & 0 & 8,755 & 0 & 0 & 8,755 \\
\hline $\begin{array}{l}\text { Total Flow (dry } \\
\text { matter) }\end{array}$ & $\mathrm{kg} / \mathrm{hr}$ & 78,728 & 0 & 0 & 78,728 & 0 & 0 & 78,728 & 0 & 0 & 78,728 \\
\hline C6 & $\mathrm{kg} / \mathrm{hr}$ & 30,474 & 0 & 0 & 30,474 & 0 & 0 & 30,474 & 0 & 0 & 30,474 \\
\hline C5 & $\mathrm{kg} / \mathrm{hr}$ & 16,534 & 0 & 0 & 16,534 & 0 & 0 & 16,534 & 0 & 0 & 16,534 \\
\hline LIGNIN & $\mathrm{kg} / \mathrm{hr}$ & 12,601 & 0 & 0 & 12,601 & 0 & 0 & 12,601 & 0 & 0 & 12,601 \\
\hline ASH & $\mathrm{kg} / \mathrm{hr}$ & 5,515 & 0 & 0 & 5,515 & 0 & 0 & 5,515 & 0 & 0 & 5,515 \\
\hline PROTEIN & $\mathrm{kg} / \mathrm{hr}$ & 2,457 & 0 & 0 & 2,457 & 0 & 0 & 2,457 & 0 & 0 & 2,457 \\
\hline EXTRACTIVES & $\mathrm{kg} / \mathrm{hr}$ & 10,421 & 0 & 0 & 10,421 & 0 & 0 & 10,421 & 0 & 0 & 10,421 \\
\hline OTHERS & $\mathrm{kg} / \mathrm{hr}$ & 729 & 0 & 0 & 729 & 0 & 0 & 729 & 0 & 0 & 729 \\
\hline Temperature & K & 298 & 298 & 298 & 298 & 298 & 298 & 298 & 298 & 298 & 298 \\
\hline Pressure & $\mathrm{atm}$ & 1 & 1 & 1 & 1 & 1 & 1 & 1 & 1 & 1 & 1 \\
\hline Vapor Frac & & 0 & 0 & 0 & 0 & 0 & 0 & 0 & 0 & 0 & 0 \\
\hline
\end{tabular}




\section{APPENDIX J - Process Flow Diagrams and Mass Balances for Supply of a $25 \%$ Clean Pine $/ 75 \%$ Logging Residue Blend to CFP - 2022 Projection}

\section{J.1 Clean Pine Blendstock}

High-level stream table information from Aspen Plus modeling output follows, for key streams associated with each process operation area. This is followed by high-level PFDs for the associated process areas. Space for stream tables was limited; below is a key to lumped components. As the stream table information focuses primarily on the high-level overall process and does not include every individual modeled stream within each process area, mass balance closure around a given unit area may not be $100 \%$.

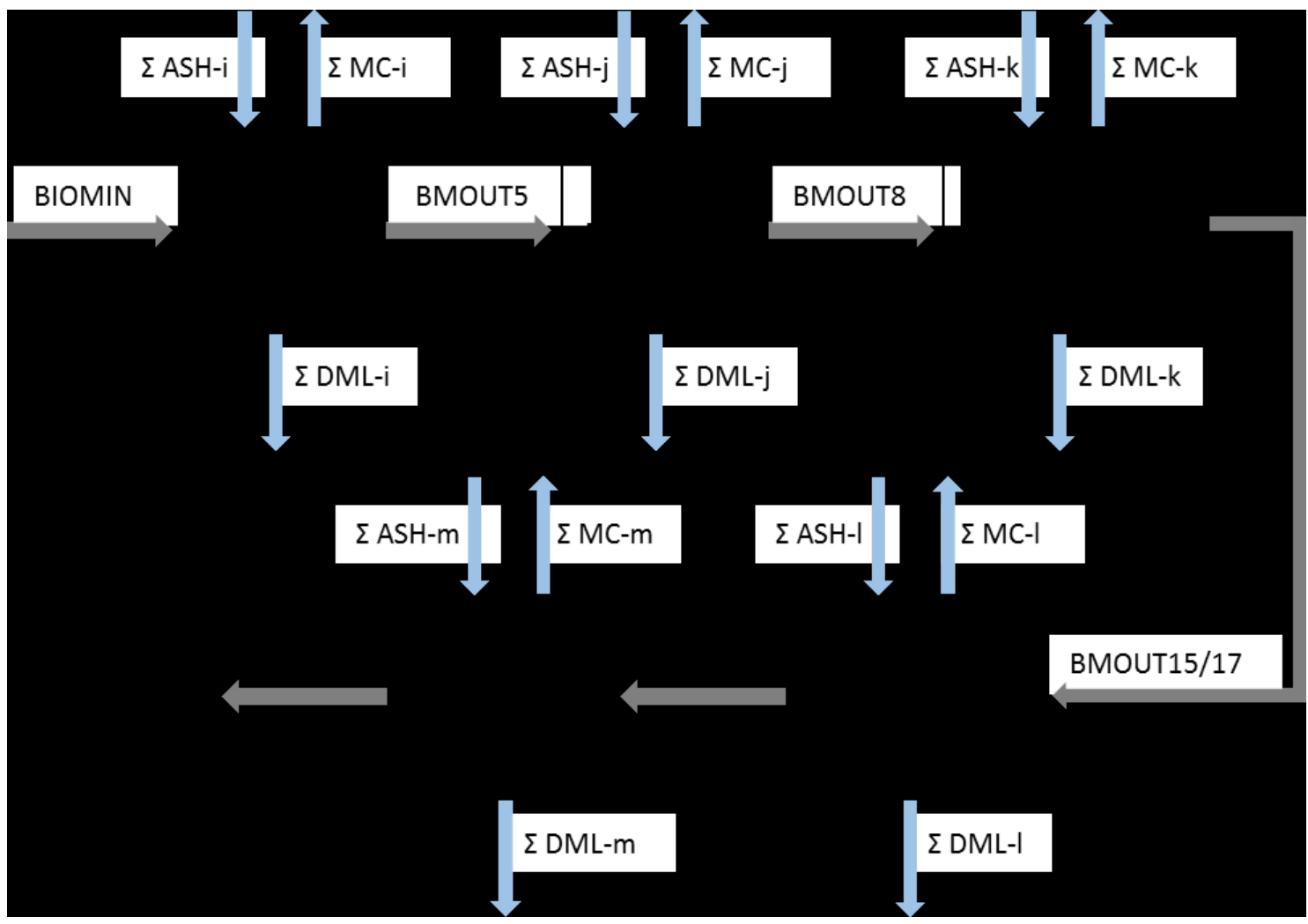

Figure J-1. High-level flowsheet showing key process areas for the clean pine blendstock in the Catalytic Fast Pyrolysis-Hydrotreating Pathway 2022 Projection. 


\section{Milestone Completion Report}

Idaho National Laboratory

\section{INL/EXT-18-51655}



Figure J-2. Detailed process flow diagram for area J100 - Harvesting.

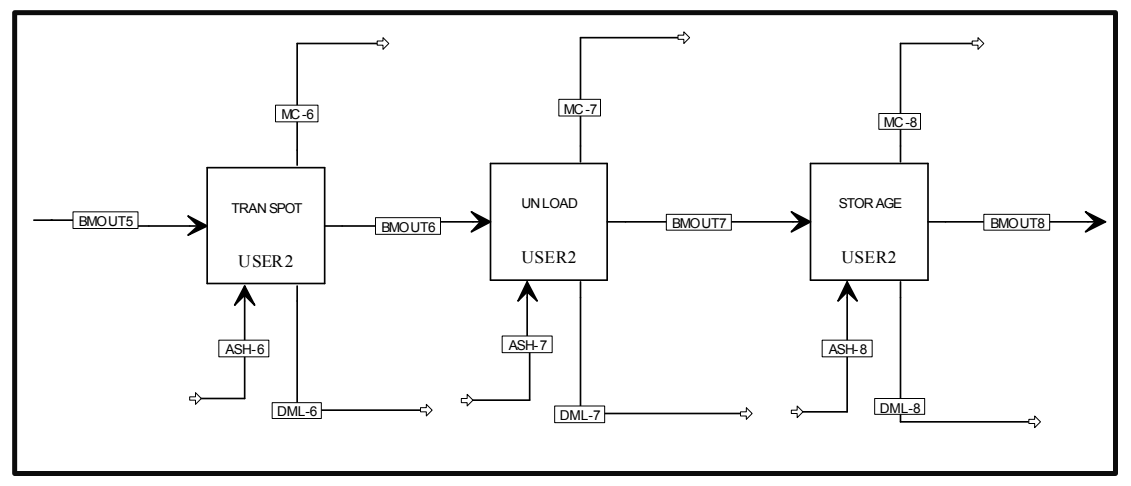

Figure J-3. Detailed process flow diagram for area J200 - Transport \& Storage. 

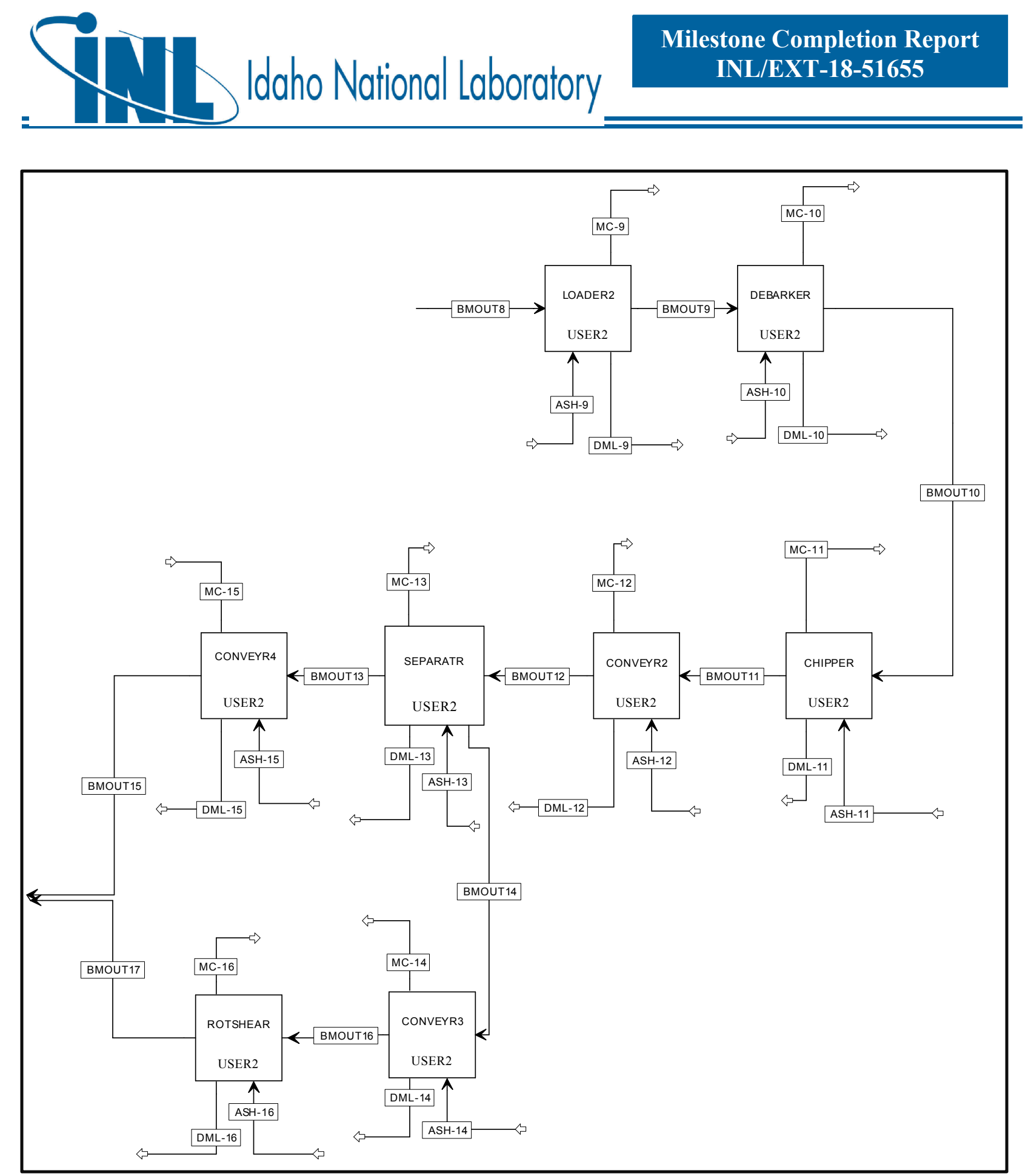

Figure J-4. Detailed process flow diagram for area J300 - Preprocessing - Size Reduction. 

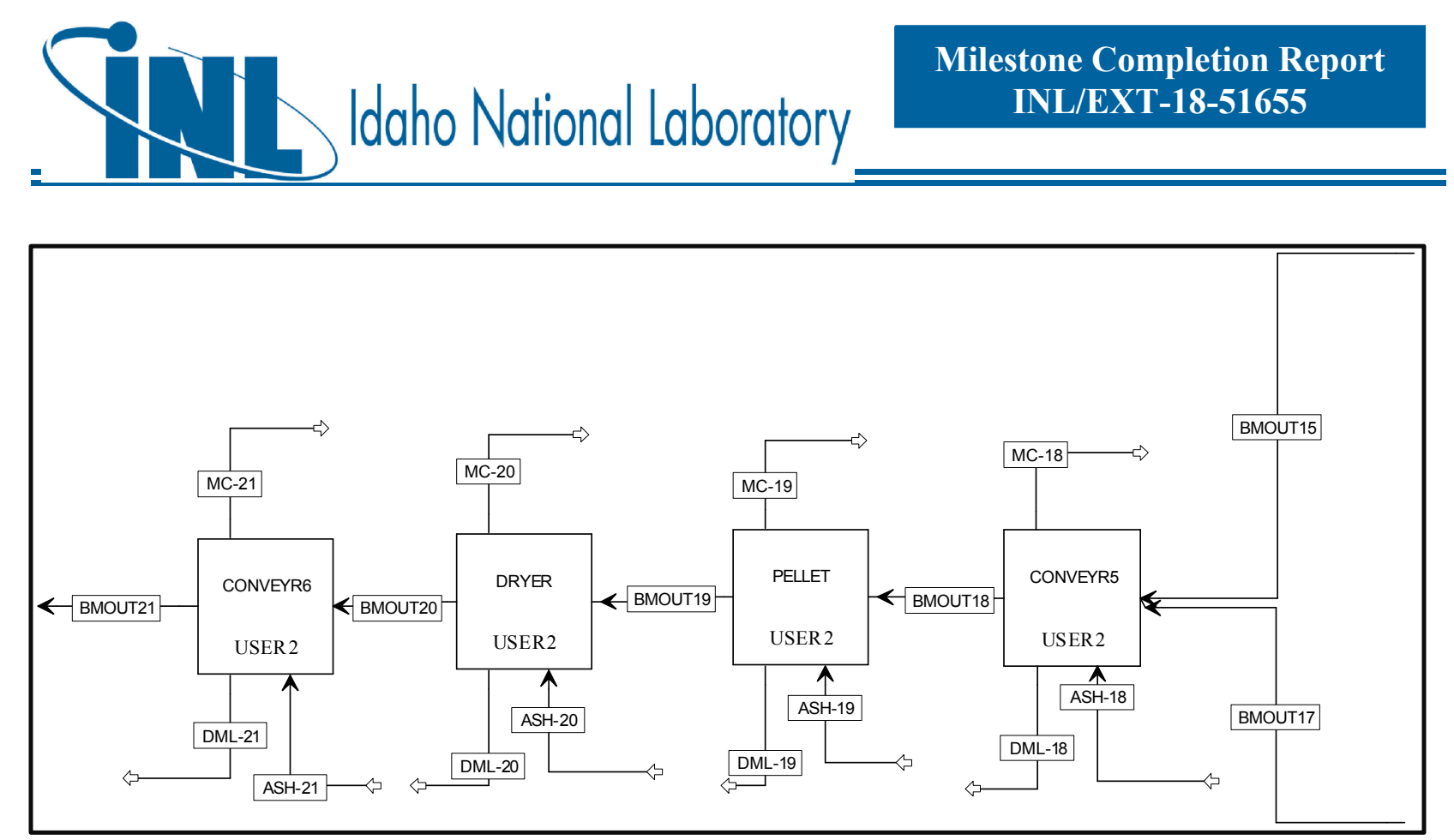

Figure J-5. Detailed process flow diagram for area J400-Preprocessing - Pelleting.

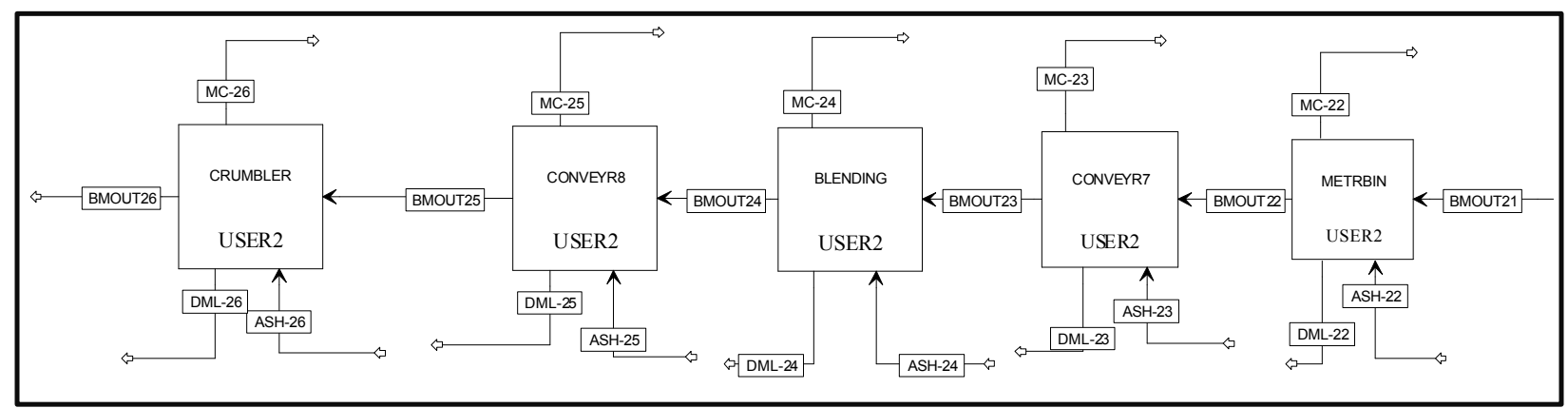

Figure J-6. Detailed process flow diagram for area J500 - Feeding. 


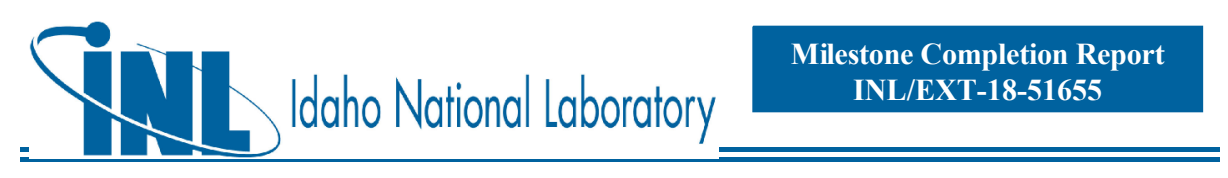

Table J-1. Clean pine Aspen Plus mass balances for the Catalytic Fast Pyrolysis-Hydrotreating Pathway 2022 Projection.

\begin{tabular}{|c|c|c|c|c|c|c|c|c|c|c|c|c|c|}
\hline Component & unit & BIOMIN & DML-1 & MC-1 & BMOUT1 & DML-2 & MC-2 & BMOUT2 & $\begin{array}{l}\text { DML- } \\
3\end{array}$ & MC-3 & BMOUT3 & $\begin{array}{l}\text { DML- } \\
4\end{array}$ & MC-4 \\
\hline $\begin{array}{l}\text { Overall Flow } \\
\text { (moisture and dry }\end{array}$ & $\mathrm{kg} / \mathrm{hr}$ & 39,537 & 0 & 0 & 39,537 & 0 & 0 & 39,537 & 761 & 608 & 38,167 & 0 & 0 \\
\hline Moisture Flow & $\mathrm{kg} / \mathrm{hr}$ & 17,792 & 0 & 0 & 17,792 & 0 & 0 & 17,792 & 0 & 608 & 17,183 & 0 & 0 \\
\hline $\begin{array}{l}\text { Total Flow (dry } \\
\text { matter) }\end{array}$ & $\mathrm{kg} / \mathrm{hr}$ & 21,745 & 0 & 0 & 21,745 & 0 & 0 & 21,745 & 761 & 0 & 20,984 & 0 & 0 \\
\hline C6 & $\mathrm{kg} / \mathrm{hr}$ & 8,052 & 0 & 0 & 8,052 & 0 & 0 & 8,052 & 140 & 0 & 7,912 & 0 & 0 \\
\hline C5 & $\mathrm{kg} / \mathrm{hr}$ & 4,653 & 0 & 0 & 4,653 & 0 & 0 & 4,653 & 220 & 0 & 4,433 & 0 & 0 \\
\hline LIGNIN & $\mathrm{kg} / \mathrm{hr}$ & 3,357 & 0 & 0 & 3,357 & 0 & 0 & 3,357 & 49 & 0 & 3,308 & 0 & 0 \\
\hline ASH & $\mathrm{kg} / \mathrm{hr}$ & 1,522 & 0 & 0 & 1,522 & 0 & 0 & 1,522 & 0 & 0 & 1,522 & 0 & 0 \\
\hline PROTEIN & $\mathrm{kg} / \mathrm{hr}$ & 659 & 0 & 0 & 659 & 0 & 0 & 659 & 23 & 0 & 636 & 0 & 0 \\
\hline EXTRACTIVES & $\mathrm{kg} / \mathrm{hr}$ & 3,123 & 0 & 0 & 3,123 & 0 & 0 & 3,123 & 228 & 0 & 2,894 & 0 & 0 \\
\hline OTHERS & $\mathrm{kg} / \mathrm{hr}$ & 378 & 0 & 0 & 378 & 0 & 0 & 378 & 100 & 0 & 278 & 0 & 0 \\
\hline Temperature & K & 298 & 298 & 298 & 298 & 298 & 298 & 298 & 298 & 298 & 298 & 298 & 298 \\
\hline Pressure & $\mathrm{atm}$ & 1 & 1 & 1 & 1 & 1 & 1 & 1 & 1 & 1 & 1 & 1 & 1 \\
\hline Vapor Frac & & 0 & 0 & 0 & 0 & 0 & 0 & 0 & 0 & 0 & 0 & 0 & 0 \\
\hline
\end{tabular}






Table J-1. Continued

\begin{tabular}{|c|c|c|c|c|c|c|c|c|c|c|c|c|}
\hline Component & unit & BMOUT4 & DML-5 & MC-5 & BMOUT5 & DML-6 & MC-6 & BMOUT6 & $\begin{array}{l}\text { DML- } \\
7\end{array}$ & MC-7 & BMOUT7 & $\begin{array}{l}\text { DML- } \\
8\end{array}$ \\
\hline $\begin{array}{l}\text { Overall Flow } \\
\text { (moisture and dry }\end{array}$ & $\mathrm{kg} / \mathrm{hr}$ & 38,167 & 420 & 10,323 & 27,425 & 0 & 0 & 27,425 & 0 & 0 & 27,425 & 0 \\
\hline Moisture Flow & $\mathrm{kg} / \mathrm{hr}$ & 17,183 & 0 & 10,323 & 6,861 & 0 & 0 & 6,861 & 0 & 0 & 6,861 & 0 \\
\hline $\begin{array}{l}\text { Total Flow (dry } \\
\text { matter) }\end{array}$ & $\mathrm{kg} / \mathrm{hr}$ & 20,984 & 420 & 0 & 20,564 & 0 & 0 & 20,564 & 0 & 0 & 20,564 & 0 \\
\hline C6 & $\mathrm{kg} / \mathrm{hr}$ & 7,912 & 77 & 0 & 7,834 & 0 & 0 & 7,834 & 0 & 0 & 7,834 & 0 \\
\hline C5 & $\mathrm{kg} / \mathrm{hr}$ & 4,433 & 121 & 0 & 4,312 & 0 & 0 & 4,312 & 0 & 0 & 4,312 & 0 \\
\hline LIGNIN & $\mathrm{kg} / \mathrm{hr}$ & 3,308 & 27 & 0 & 3,281 & 0 & 0 & 3,281 & 0 & 0 & 3,281 & 0 \\
\hline ASH & $\mathrm{kg} / \mathrm{hr}$ & 1,522 & 0 & 0 & 1,522 & 0 & 0 & 1,522 & 0 & 0 & 1,522 & 0 \\
\hline PROTEIN & $\mathrm{kg} / \mathrm{hr}$ & 636 & 13 & 0 & 624 & 0 & 0 & 624 & 0 & 0 & 624 & 0 \\
\hline EXTRACTIVES & $\mathrm{kg} / \mathrm{hr}$ & 2,894 & 126 & 0 & 2,769 & 0 & 0 & 2,769 & 0 & 0 & 2,769 & 0 \\
\hline OTHERS & $\mathrm{kg} / \mathrm{hr}$ & 278 & 55 & 0 & 223 & 0 & 0 & 223 & 0 & 0 & 223 & 0 \\
\hline Temperature & K & 298 & 298 & 298 & 298 & 298 & 298 & 298 & 298 & 298 & 298 & 298 \\
\hline Pressure & $\mathrm{atm}$ & 1 & 1 & 1 & 1 & 1 & 1 & 1 & 1 & 1 & 1 & 1 \\
\hline Vapor Frac & & 0 & 0 & 0 & 0 & 0 & 0 & 0 & 0 & 0 & 0 & 0 \\
\hline
\end{tabular}




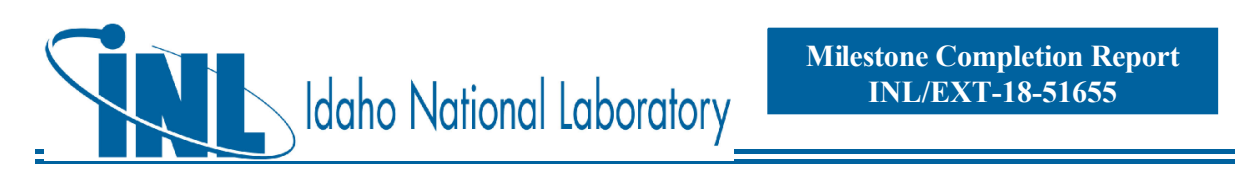

Table J-1. Continued

\begin{tabular}{|c|c|c|c|c|c|c|c|c|c|c|c|c|}
\hline Component & unit & MC-8 & BMOUT & DML-9 & MC-9 & BMOUT9 & DML-10 & MC-10 & BMOUT10 & $\begin{array}{l}\text { DML- } \\
11\end{array}$ & MC- & BMOUT11 \\
\hline $\begin{array}{l}\text { Overall Flow } \\
\text { (moisture and dry }\end{array}$ & $\mathrm{kg} / \mathrm{hr}$ & 0 & 27,425 & 0 & 0 & 27,425 & 411 & 0 & 27,014 & 405 & 990 & 25,619 \\
\hline Moisture Flow & $\mathrm{kg} / \mathrm{hr}$ & 0 & 6,861 & 0 & 0 & 6,861 & 103 & 0 & 6,758 & 0 & 990 & 5,768 \\
\hline $\begin{array}{l}\text { Total Flow (dry } \\
\text { matter) }\end{array}$ & $\mathrm{kg} / \mathrm{hr}$ & 0 & 20,564 & 0 & 0 & 20,564 & 309 & 0 & 20,256 & 405 & 0 & 19,851 \\
\hline C6 & $\mathrm{kg} / \mathrm{hr}$ & 0 & 7,834 & 0 & 0 & 7,834 & 57 & 0 & 7,777 & 112 & 0 & 7,665 \\
\hline C5 & $\mathrm{kg} / \mathrm{hr}$ & 0 & 4,312 & 0 & 0 & 4,312 & 89 & 0 & 4,223 & 63 & 0 & 4,160 \\
\hline LIGNIN & $\mathrm{kg} / \mathrm{hr}$ & 0 & 3,281 & 0 & 0 & 3,281 & 20 & 0 & 3,261 & 79 & 0 & 3,183 \\
\hline ASH & $\mathrm{kg} / \mathrm{hr}$ & 0 & 1,522 & 0 & 0 & 1,522 & 0 & 0 & 1,522 & 101 & 0 & 1,421 \\
\hline PROTEIN & $\mathrm{kg} / \mathrm{hr}$ & 0 & 624 & 0 & 0 & 624 & 9 & 0 & 614 & 0 & 0 & 614 \\
\hline EXTRACTIVES & $\mathrm{kg} / \mathrm{hr}$ & 0 & 2,769 & 0 & 0 & 2,769 & 92 & 0 & 2,676 & 50 & 0 & 2,626 \\
\hline OTHERS & $\mathrm{kg} / \mathrm{hr}$ & 0 & 223 & 0 & 0 & 223 & 41 & 0 & 182 & 0 & 0 & 182 \\
\hline Temperature & K & 298 & 298 & 298 & 298 & 298 & 298 & 298 & 298 & 298 & 298 & 298 \\
\hline Pressure & atm & 1 & 1 & 1 & 1 & 1 & 1 & 1 & 1 & 1 & 1 & 1 \\
\hline Vapor Frac & & 0 & 0 & 0 & 0 & 0 & 0 & 0 & 0 & 0 & 0 & 0 \\
\hline
\end{tabular}




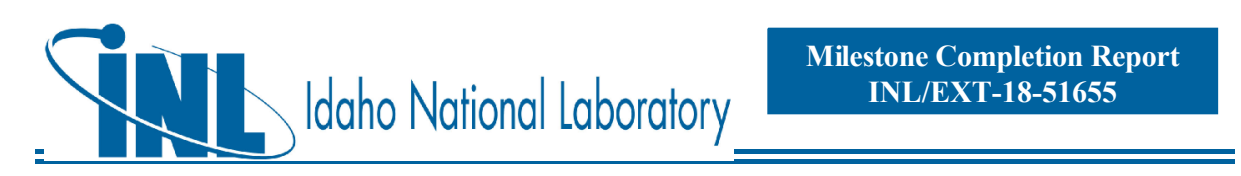

Table J-1. Continued

\begin{tabular}{|c|c|c|c|c|c|c|c|c|c|c|c|c|}
\hline Component & unit & $\begin{array}{l}\text { DML- } \\
12\end{array}$ & $\begin{array}{l}\text { MC- } \\
12\end{array}$ & BMOUT1 & $\begin{array}{l}\text { DML- } \\
13\end{array}$ & $\begin{array}{l}\text { MC- } \\
13\end{array}$ & BMOUT1 & BMOUT1 & $\begin{array}{l}\text { DML- } \\
14\end{array}$ & $\begin{array}{l}\text { MC- } \\
14\end{array}$ & BMOUT1 & $\begin{array}{l}\text { DML- } \\
15\end{array}$ \\
\hline $\begin{array}{l}\text { Overall Flow } \\
\text { (moisture and dry }\end{array}$ & $\mathrm{kg} / \mathrm{hr}$ & 0 & 0 & 25,619 & 0 & 0 & 3,843 & 21,776 & 0 & 0 & 21,776 & 0 \\
\hline Moisture Flow & $\mathrm{kg} / \mathrm{hr}$ & 0 & 0 & 5,768 & 0 & 0 & 865 & 4,903 & 0 & 0 & 4,903 & 0 \\
\hline $\begin{array}{l}\text { Total Flow (dry } \\
\text { matter) }\end{array}$ & $\mathrm{kg} / \mathrm{hr}$ & 0 & 0 & 19,851 & 0 & 0 & 2,978 & 16,873 & 0 & 0 & 16,873 & 0 \\
\hline C6 & $\mathrm{kg} / \mathrm{hr}$ & 0 & 0 & 7,665 & 0 & 0 & 1,150 & 6,515 & 0 & 0 & 6,515 & 0 \\
\hline C5 & $\mathrm{kg} / \mathrm{hr}$ & 0 & 0 & 4,160 & 0 & 0 & 624 & 3,536 & 0 & 0 & 3,536 & 0 \\
\hline LIGNIN & $\mathrm{kg} / \mathrm{hr}$ & 0 & 0 & 3,183 & 0 & 0 & 477 & 2,705 & 0 & 0 & 2,705 & 0 \\
\hline ASH & $\mathrm{kg} / \mathrm{hr}$ & 0 & 0 & 1,421 & 0 & 0 & 213 & 1,208 & 0 & 0 & 1,208 & 0 \\
\hline PROTEIN & $\mathrm{kg} / \mathrm{hr}$ & 0 & 0 & 614 & 0 & 0 & 92 & 522 & 0 & 0 & 522 & 0 \\
\hline EXTRACTIVES & $\mathrm{kg} / \mathrm{hr}$ & 0 & 0 & 2,626 & 0 & 0 & 394 & 2,232 & 0 & 0 & 2,232 & 0 \\
\hline OTHERS & $\mathrm{kg} / \mathrm{hr}$ & 0 & 0 & 182 & 0 & 0 & 27 & 155 & 0 & 0 & 155 & 0 \\
\hline Temperature & K & 298 & 298 & 298 & 298 & 298 & 298 & 298 & 298 & 298 & 298 & 298 \\
\hline Pressure & atm & 1 & 1 & 1 & 1 & 1 & 1 & 1 & 1 & 1 & 1 & 1 \\
\hline Vapor Frac & & 0 & 0 & 0 & 0 & 0 & 0 & 0 & 0 & 0 & 0 & 0 \\
\hline
\end{tabular}




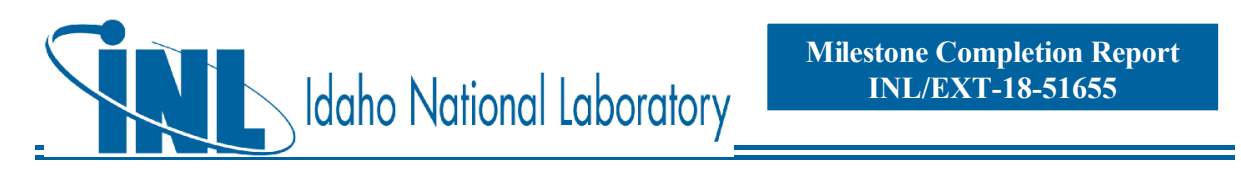

Table J-1. Continued

\begin{tabular}{|c|c|c|c|c|c|c|c|c|c|c|c|c|}
\hline Component & unit & MC-15 & BMOUT15 & DML-16 & MC-16 & BMOUT17 & $\begin{array}{l}\text { DML- } \\
18\end{array}$ & MC-18 & BMOUT18 & $\begin{array}{l}\text { DML- } \\
19\end{array}$ & MC-19 & BMOUT19 \\
\hline $\begin{array}{l}\text { Overall Flow } \\
\text { (moisture and dry }\end{array}$ & $\mathrm{kg} / \mathrm{hr}$ & 143 & 3,700 & 169 & 853 & 20,754 & 0 & 0 & 24,454 & 0 & 1,295 & 23,158 \\
\hline Moisture Flow & $\mathrm{kg} / \mathrm{hr}$ & 143 & 722 & 0 & 853 & 4,050 & 0 & 0 & 4,772 & 0 & 1,295 & 3,476 \\
\hline $\begin{array}{l}\text { Total Flow (dry } \\
\text { matter) }\end{array}$ & $\mathrm{kg} / \mathrm{hr}$ & 0 & 2,978 & 169 & 0 & 16,704 & 0 & 0 & 19,682 & 0 & 0 & 19,682 \\
\hline C6 & $\mathrm{kg} / \mathrm{hr}$ & 0 & 1,150 & 47 & 0 & 6,469 & 0 & 0 & 7,618 & 0 & 0 & 7,618 \\
\hline C5 & $\mathrm{kg} / \mathrm{hr}$ & 0 & 624 & 26 & 0 & 3,509 & 0 & 0 & 4,133 & 0 & 0 & 4,133 \\
\hline LIGNIN & $\mathrm{kg} / \mathrm{hr}$ & 0 & 477 & 33 & 0 & 2,673 & 0 & 0 & 3,150 & 0 & 0 & 3,150 \\
\hline ASH & $\mathrm{kg} / \mathrm{hr}$ & 0 & 213 & 42 & 0 & 1,166 & 0 & 0 & 1,379 & 0 & 0 & 1,379 \\
\hline PROTEIN & $\mathrm{kg} / \mathrm{hr}$ & 0 & 92 & 0 & 0 & 522 & 0 & 0 & 614 & 0 & 0 & 614 \\
\hline EXTRACTIVES & $\mathrm{kg} / \mathrm{hr}$ & 0 & 394 & 21 & 0 & 2,211 & 0 & 0 & 2,605 & 0 & 0 & 2,605 \\
\hline OTHERS & $\mathrm{kg} / \mathrm{hr}$ & 0 & 27 & 0 & 0 & 155 & 0 & 0 & 182 & 0 & 0 & 182 \\
\hline Temperature & $\mathrm{K}$ & 298 & 298 & 298 & 298 & 298 & 298 & 298 & 298 & 298 & 298 & 298 \\
\hline Pressure & $\mathrm{atm}$ & 1 & 1 & 1 & 1 & 1 & 1 & 1 & 1 & 1 & 1 & 1 \\
\hline Vapor Frac & & 0 & 0 & 0 & 0 & 0 & 0 & 0 & 0 & 0 & 0 & 0 \\
\hline
\end{tabular}




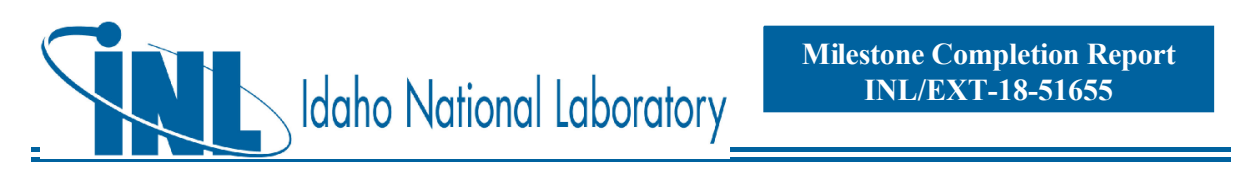

Table J-1. Continued

\begin{tabular}{|c|c|c|c|c|c|c|c|c|c|c|c|c|}
\hline Component & unit & DML-20 & MC-20 & BMOUT20 & DML-21 & MC-21 & BMOUT21 & $\begin{array}{l}\text { DML- } \\
22\end{array}$ & MC-22 & BMOUT22 & $\begin{array}{l}\text { DML- } \\
23\end{array}$ & $\begin{array}{l}\text { MC- } \\
23\end{array}$ \\
\hline $\begin{array}{l}\text { Overall Flow } \\
\text { (moisture and dry }\end{array}$ & $\mathrm{kg} / \mathrm{hr}$ & 0 & 1,288 & 21,871 & 0 & 0 & 21,871 & 0 & 0 & 21,871 & 0 & 0 \\
\hline Moisture Flow & $\mathrm{kg} / \mathrm{hr}$ & 0 & 1,288 & 2,189 & 0 & 0 & 2,189 & 0 & 0 & 2,189 & 0 & 0 \\
\hline $\begin{array}{l}\text { Total Flow (dry } \\
\text { matter) }\end{array}$ & $\mathrm{kg} / \mathrm{hr}$ & 0 & 0 & 19,682 & 0 & 0 & 19,682 & 0 & 0 & 19,682 & 0 & 0 \\
\hline C6 & $\mathrm{kg} / \mathrm{hr}$ & 0 & 0 & 7,618 & 0 & 0 & 7,618 & 0 & 0 & 7,618 & 0 & 0 \\
\hline $\mathrm{C} 5$ & $\mathrm{~kg} / \mathrm{hr}$ & 0 & 0 & 4,133 & 0 & 0 & 4,133 & 0 & 0 & 4,133 & 0 & 0 \\
\hline LIGNIN & $\mathrm{kg} / \mathrm{hr}$ & 0 & 0 & 3,150 & 0 & 0 & 3,150 & 0 & 0 & 3,150 & 0 & 0 \\
\hline ASH & $\mathrm{kg} / \mathrm{hr}$ & 0 & 0 & 1,379 & 0 & 0 & 1,379 & 0 & 0 & 1,379 & 0 & 0 \\
\hline PROTEIN & $\mathrm{kg} / \mathrm{hr}$ & 0 & 0 & 614 & 0 & 0 & 614 & 0 & 0 & 614 & 0 & 0 \\
\hline EXTRACTIVES & $\mathrm{kg} / \mathrm{hr}$ & 0 & 0 & 2,605 & 0 & 0 & 2,605 & 0 & 0 & 2,605 & 0 & 0 \\
\hline OTHERS & $\mathrm{kg} / \mathrm{hr}$ & 0 & 0 & 182 & 0 & 0 & 182 & 0 & 0 & 182 & 0 & 0 \\
\hline Temperature & K & 298 & 298 & 298 & 298 & 298 & 298 & 298 & 298 & 298 & 298 & 298 \\
\hline Pressure & atm & 1 & 1 & 1 & 1 & 1 & 1 & 1 & 1 & 1 & 1 & 1 \\
\hline Vapor Frac & & 0 & 0 & 0 & 0 & 0 & 0 & 0 & 0 & 0 & 0 & 0 \\
\hline
\end{tabular}




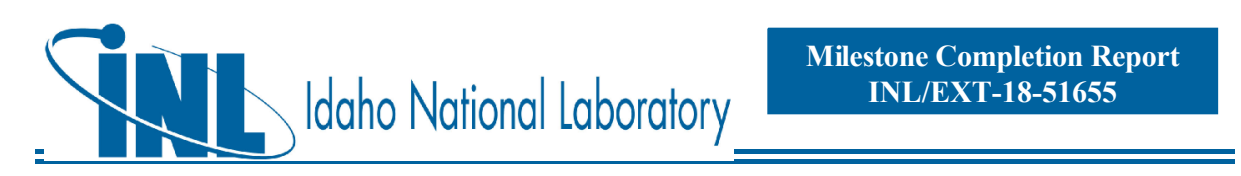

Table J-1. Continued






\section{J.2 Forest Residue Blendstock}

High-level stream table information from Aspen Plus modeling output follows, for key streams associated with each process operation area. This is followed by high-level PFDs for the associated process areas. Space for stream tables was limited; below is a key to lumped components. As the stream table information focuses primarily on the high-level overall process and does not include every individual modeled stream within each process area, mass balance closure around a given unit area may not be $100 \%$.


Figure J-7. High-level flowsheet showing key process areas for the forest residue blendstock in the Catalytic Fast Pyrolysis-Hydrotreating Pathway 2022 Projection. 


\section{Milestone Completion Report}

Idaho National Laboratory

\section{INL/EXT-18-51655}

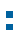

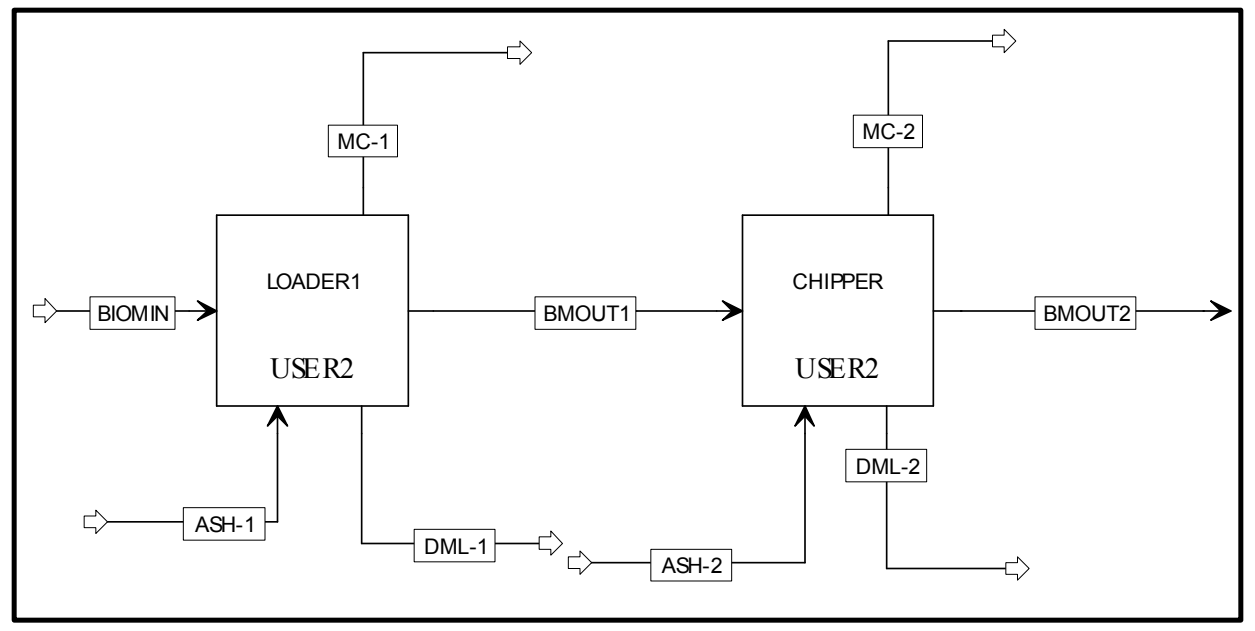

Figure J-8. Detailed process flow diagram for area J100 - Harvesting.

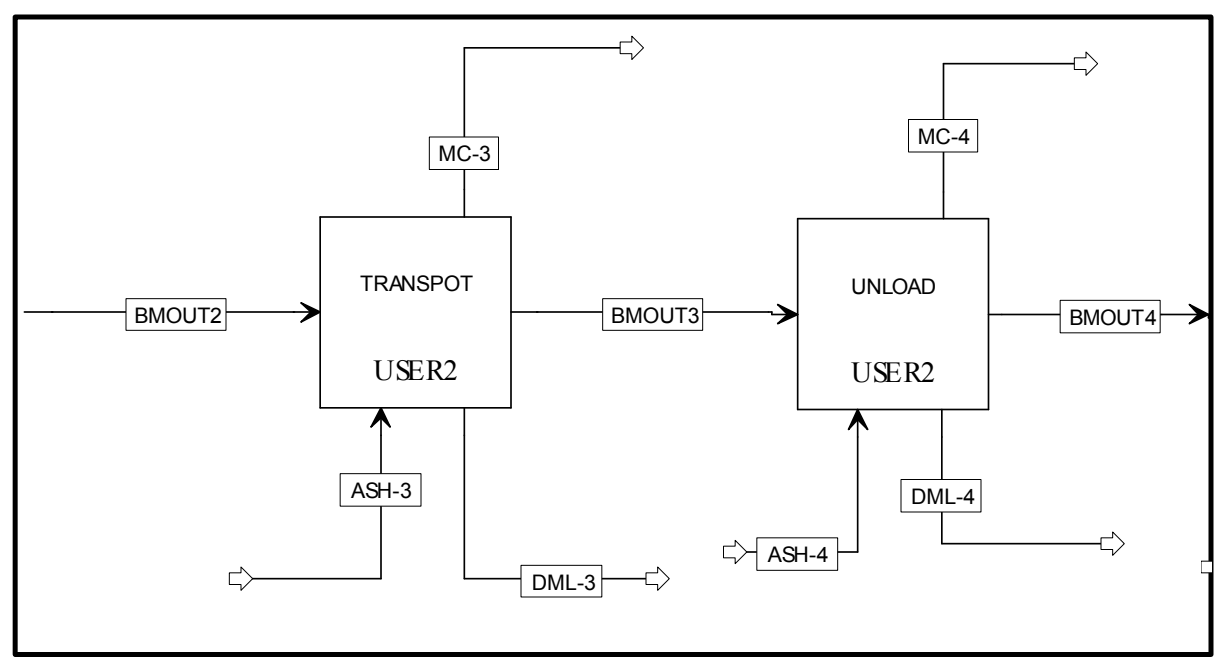

Figure J-9. Detailed process flow diagram for area J200 - Transport. 

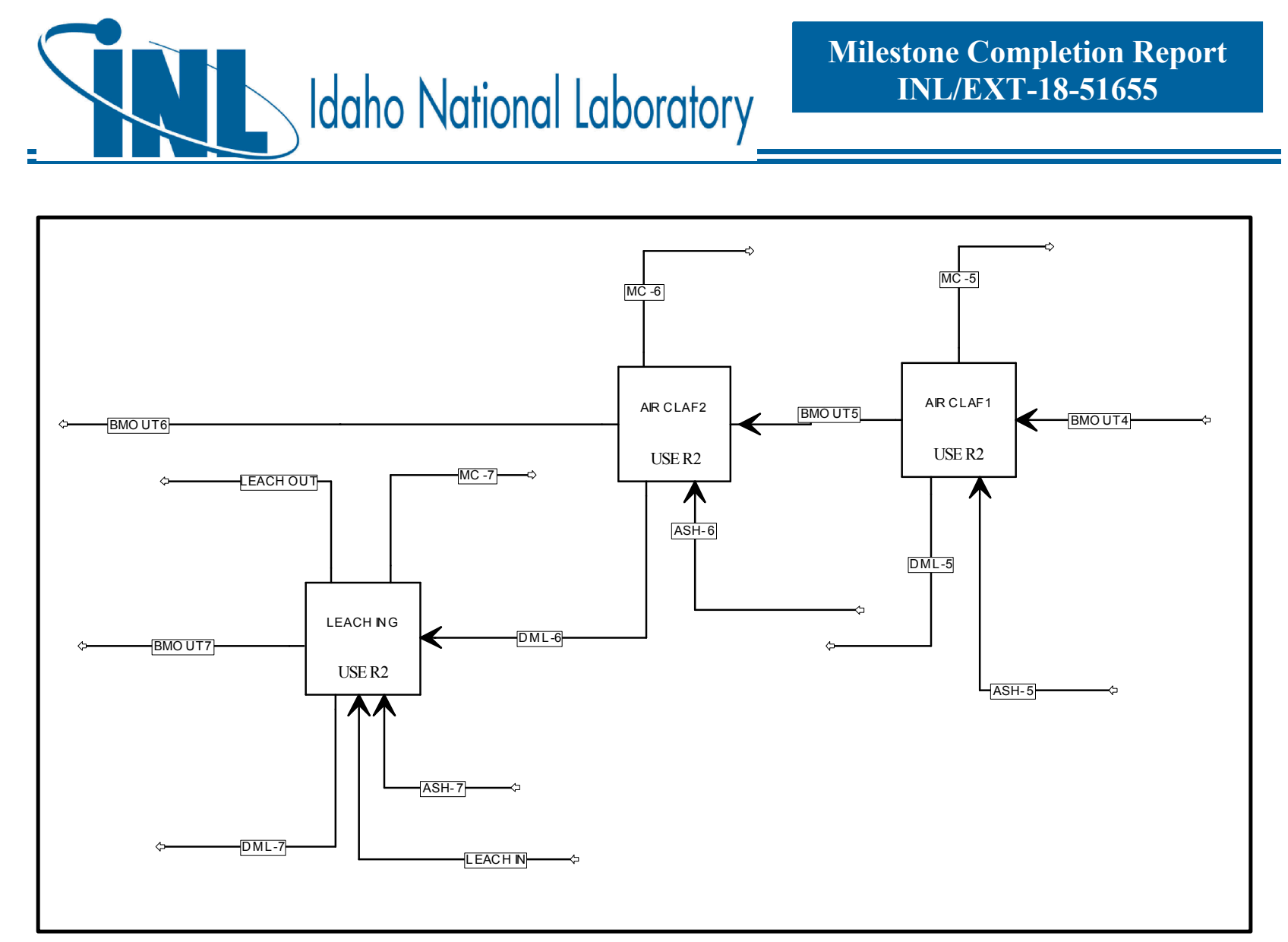

Figure J-10. Detailed process flow diagram for area J300 - Preprocessing - Air Classification \& Leaching.



Figure J-11. Detailed process flow diagram for area J400-Drying \& Size Reduction. 


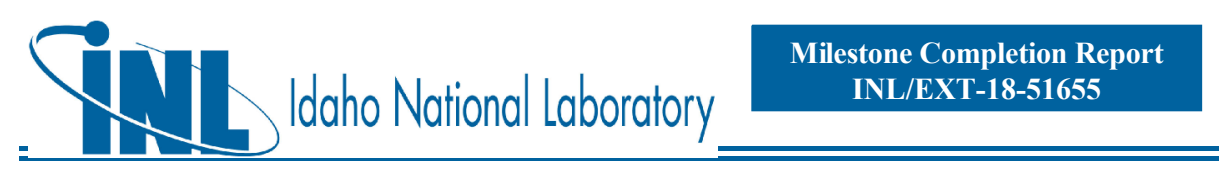

Table J-2. Forest residue Aspen Plus mass balances for the Catalytic Fast Pyrolysis-Hydrotreating Pathway 2022 Projection.

\begin{tabular}{|c|c|c|c|c|c|c|c|c|c|c|c|c|}
\hline Component & Unit & BIOMIN & DML-1 & MC-1 & BMOUT1 & DML-2 & MC-2 & BMOUT2 & $\begin{array}{l}\text { DML- } \\
3\end{array}$ & $\begin{array}{l}\text { MC- } \\
3\end{array}$ & BMOUT3 & DML- \\
\hline $\begin{array}{l}\text { Overall Flow (moisture } \\
\text { and dry matter) }\end{array}$ & $\mathrm{kg} / \mathrm{hr}$ & 99,260 & 0 & 0 & 99,260 & 3,474 & 4,719 & 91,067 & 0 & 0 & 91,067 & 0 \\
\hline Moisture Flow & $\mathrm{kg} / \mathrm{hr}$ & 29,778 & 0 & 0 & 29,778 & 0 & 4,719 & 25,059 & 0 & 0 & 25,059 & 0 \\
\hline Total Flow (dry matter) & $\mathrm{kg} / \mathrm{hr}$ & 69,482 & 0 & 0 & 69,482 & 3,474 & 0 & 66,008 & 0 & 0 & 66,008 & 0 \\
\hline C6 & $\mathrm{kg} / \mathrm{hr}$ & 27,793 & 0 & 0 & 27,793 & 1,390 & 0 & 26,403 & 0 & 0 & 26,403 & 0 \\
\hline C5 & $\mathrm{kg} / \mathrm{hr}$ & 18,760 & 0 & 0 & 18,760 & 938 & 0 & 17,822 & 0 & 0 & 17,822 & 0 \\
\hline LIGNIN & $\mathrm{kg} / \mathrm{hr}$ & 18,760 & 0 & 0 & 18,760 & 938 & 0 & 17,822 & 0 & 0 & 17,822 & 0 \\
\hline ASH & $\mathrm{kg} / \mathrm{hr}$ & 695 & 0 & 0 & 695 & 35 & 0 & 660 & 0 & 0 & 660 & 0 \\
\hline PROTEIN & $\mathrm{kg} / \mathrm{hr}$ & 0 & 0 & 0 & 0 & 0 & 0 & 0 & 0 & 0 & 0 & 0 \\
\hline EXTRACTIVES & $\mathrm{kg} / \mathrm{hr}$ & 3,474 & 0 & 0 & 3,474 & 174 & 0 & 3,300 & 0 & 0 & 3,300 & 0 \\
\hline OTHERS & $\mathrm{kg} / \mathrm{hr}$ & 0 & 0 & 0 & 0 & 0 & 0 & 0 & 0 & 0 & 0 & 0 \\
\hline Temperature & K & 298 & 298 & 298 & 298 & 298 & 298 & 298 & 298 & 298 & 298 & 298 \\
\hline Pressure & atm & 1 & 1 & 1 & 1 & 1 & 1 & 1 & 1 & 1 & 1 & 1 \\
\hline Vapor Frac & & 0 & 0 & 0 & 0 & 0 & 0 & 0 & 0 & 0 & 0 & 0 \\
\hline
\end{tabular}




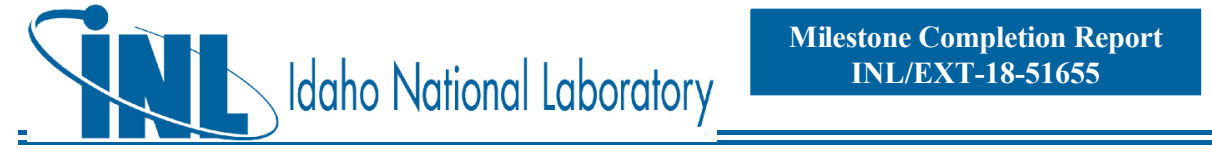

Table J-2. Continued

\begin{tabular}{|c|c|c|c|c|c|c|c|c|c|c|c|}
\hline Component & Unit & MC- & $\begin{array}{c}\text { BMOUT } \\
4\end{array}$ & DML-5 & MC-5 & BMOUT5 & DML-6 & MC-6 & BMOUT6 & $\begin{array}{l}\text { LEACHI } \\
\mathrm{N}\end{array}$ & $\begin{array}{c}\text { LEACHOU } \\
\text { T }\end{array}$ \\
\hline $\begin{array}{l}\text { Overall Flow (moisture } \\
\text { and dry matter) }\end{array}$ & $\mathrm{kg} / \mathrm{hr}$ & 0 & 91,067 & 4,291 & 1,629 & 85,147 & 8,515 & 0 & 76,633 & 25,545 & 25,545 \\
\hline Moisture Flow & $\mathrm{kg} / \mathrm{hr}$ & 0 & 25,059 & 0 & 1,629 & 23,430 & 2,343 & 0 & 21,087 & 0 & 0 \\
\hline Total Flow (dry matter) & $\mathrm{kg} / \mathrm{hr}$ & 0 & 66,008 & 4,291 & 0 & 61,717 & 6,172 & 0 & 55,546 & 0 & 0 \\
\hline C6 & $\mathrm{kg} / \mathrm{hr}$ & 0 & 26,403 & 931 & 0 & 25,472 & 1,588 & 0 & 23,884 & 0 & 0 \\
\hline C5 & $\mathrm{kg} / \mathrm{hr}$ & 0 & 17,822 & 1,241 & 0 & 16,581 & 2,118 & 0 & 14,464 & 0 & 0 \\
\hline LIGNIN & $\mathrm{kg} / \mathrm{hr}$ & 0 & 17,822 & 931 & 0 & 16,891 & 1,588 & 0 & 15,303 & 0 & 0 \\
\hline ASH & $\mathrm{kg} / \mathrm{hr}$ & 0 & 660 & 198 & 0 & 462 & 185 & 0 & 277 & 0 & 0 \\
\hline PROTEIN & $\mathrm{kg} / \mathrm{hr}$ & 0 & 0 & 0 & 0 & 0 & 0 & 0 & 0 & 0 & 0 \\
\hline EXTRACTIVES & $\mathrm{kg} / \mathrm{hr}$ & 0 & 3,300 & 990 & 0 & 2,310 & 693 & 0 & 1,617 & 0 & 0 \\
\hline OTHERS & $\mathrm{kg} / \mathrm{hr}$ & 0 & 0 & 0 & 0 & 0 & 0 & 0 & 0 & 0 & 0 \\
\hline Temperature & $\mathrm{K}$ & 298 & 298 & 298 & 298 & 298 & 298 & 298 & 298 & 298 & 298 \\
\hline Pressure & $\mathrm{atm}$ & 1 & 1 & 1 & 1 & 1 & 1 & 1 & 1 & 1 & 1 \\
\hline Vapor Frac & & 0 & 0 & 0 & 0 & 0 & 0 & 0 & 0 & 0 & 0 \\
\hline
\end{tabular}




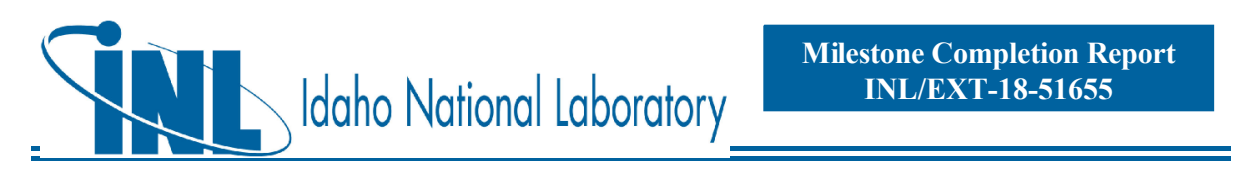

Table J-2. Continued

\begin{tabular}{|c|c|c|c|c|c|c|c|c|c|c|}
\hline Component & Unit & $\begin{array}{l}\text { DML- } \\
7\end{array}$ & $\begin{array}{l}\text { MC- } \\
7\end{array}$ & BMOUT7 & $\begin{array}{l}\text { DML- } \\
8\end{array}$ & MC-8 & BMOUT8 & DML-9 & MC-9 & BMOUT9 \\
\hline $\begin{array}{l}\text { Overall Flow (moisture } \\
\text { and dry matter) }\end{array}$ & $\mathrm{kg} / \mathrm{hr}$ & 701 & 0 & 7,813 & 0 & 16,434 & 68,012 & 1,224 & 136 & 66,651 \\
\hline Moisture Flow & $\mathrm{kg} / \mathrm{hr}$ & 189 & 0 & 2,154 & 0 & 16,434 & 6,806 & 0 & 136 & 6,670 \\
\hline Total Flow (dry matter) & $\mathrm{kg} / \mathrm{hr}$ & 512 & 0 & 5,660 & 0 & 0 & 61,205 & 1,224 & 0 & 59,981 \\
\hline C6 & $\mathrm{kg} / \mathrm{hr}$ & 48 & 0 & 1,636 & 0 & 0 & 25,521 & 490 & 0 & 25,031 \\
\hline C5 & $\mathrm{kg} / \mathrm{hr}$ & 145 & 0 & 2,262 & 0 & 0 & 16,726 & 331 & 0 & 16,395 \\
\hline LIGNIN & $\mathrm{kg} / \mathrm{hr}$ & 48 & 0 & 1,636 & 0 & 0 & 16,940 & 331 & 0 & 16,609 \\
\hline ASH & $\mathrm{kg} / \mathrm{hr}$ & 129 & 0 & 55 & 0 & 0 & 333 & 12 & 0 & 320 \\
\hline PROTEIN & $\mathrm{kg} / \mathrm{hr}$ & 0 & 0 & 0 & 0 & 0 & 0 & 0 & 0 & 0 \\
\hline EXTRACTIVES & $\mathrm{kg} / \mathrm{hr}$ & 624 & 0 & 69 & 0 & 0 & 1,687 & 61 & 0 & 1,625 \\
\hline OTHERS & $\mathrm{kg} / \mathrm{hr}$ & 0 & 0 & 0 & 0 & 0 & 0 & 0 & 0 & 0 \\
\hline Temperature & $\mathrm{K}$ & 298 & 298 & 298 & 298 & 298 & 298 & 298 & 298 & 298 \\
\hline Pressure & $\mathrm{atm}$ & 1 & 1 & 1 & 1 & 1 & 1 & 1 & 1 & 1 \\
\hline Vapor Frac & & 0 & 0 & 0 & 0 & 0 & 0 & 0 & 0 & 0 \\
\hline
\end{tabular}




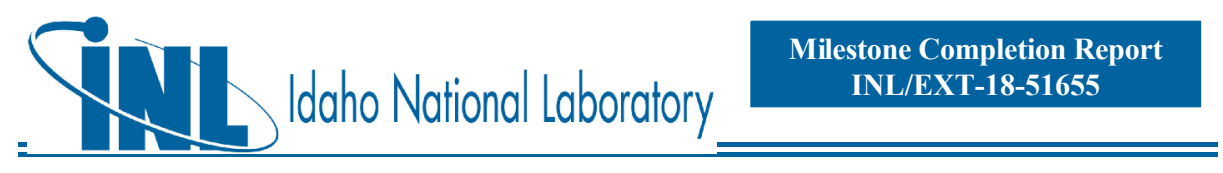

Table J-2. Continued

\begin{tabular}{|l|c|r|r|r|}
\multicolumn{1}{|c}{ Component } & \multicolumn{1}{c}{ Unit } & BML-10 & MC-10 & BMOUT10 \\
\hline $\begin{array}{l}\text { Overall Flow (moisture } \\
\text { and dry matter) }\end{array}$ & $\mathrm{kg} / \mathrm{hr}$ & 0 & 0 & 66,651 \\
\hline Moisture Flow & $\mathrm{kg} / \mathrm{hr}$ & 0 & 0 & 6,670 \\
\hline Total Flow (dry matter) & $\mathrm{kg} / \mathrm{hr}$ & 0 & 0 & 59,981 \\
\hline C6 & $\mathrm{kg} / \mathrm{hr}$ & 0 & 0 & 25,031 \\
\hline C5 & $\mathrm{kg} / \mathrm{hr}$ & 0 & 0 & 16,395 \\
\hline LIGNIN & $\mathrm{kg} / \mathrm{hr}$ & 0 & 0 & 16,609 \\
\hline ASH & $\mathrm{kg} / \mathrm{hr}$ & 0 & 0 & 320 \\
\hline PROTEIN & $\mathrm{kg} / \mathrm{hr}$ & 0 & 0 & 0 \\
\hline EXTRACTIVES & $\mathrm{kg} / \mathrm{hr}$ & 0 & 0 & 1,625 \\
\hline OTHERS & $\mathrm{kg} / \mathrm{hr}$ & 0 & 0 & 0 \\
\hline Temperature & $\mathrm{K}$ & 298 & 298 & 298 \\
\hline Pressure & $\mathrm{atm}$ & 1 & 1 & 1 \\
\hline Vapor Frac & & 0 & 0 & 0 \\
\hline
\end{tabular}




\section{APPENDIX K - Process Flow Diagrams and Mass Balances for Supply of Logging Residues to AHTL - 2018 SOT}

High-level stream table information from Aspen Plus modeling output follows, for key streams associated with each process operation area. This is followed by high-level PFDs for the associated process areas. Space for stream tables was limited; below is a key to lumped components. As the stream table information focuses primarily on the high-level overall process and does not include every individual modeled stream within each process area, mass balance closure around a given unit area may not be $100 \%$.



Figure K-1. High-level flowsheet showing key process areas for the forest residue blendstock in the Algae-Hydrothermal Liquefaction Pathway (AHTL) SOT. 


\section{Milestone Completion Report}

Idaho National Laboratory

\section{INL/EXT-18-51655}

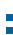



Figure K-2. Detailed process flow diagram for area K100 - Harvesting.

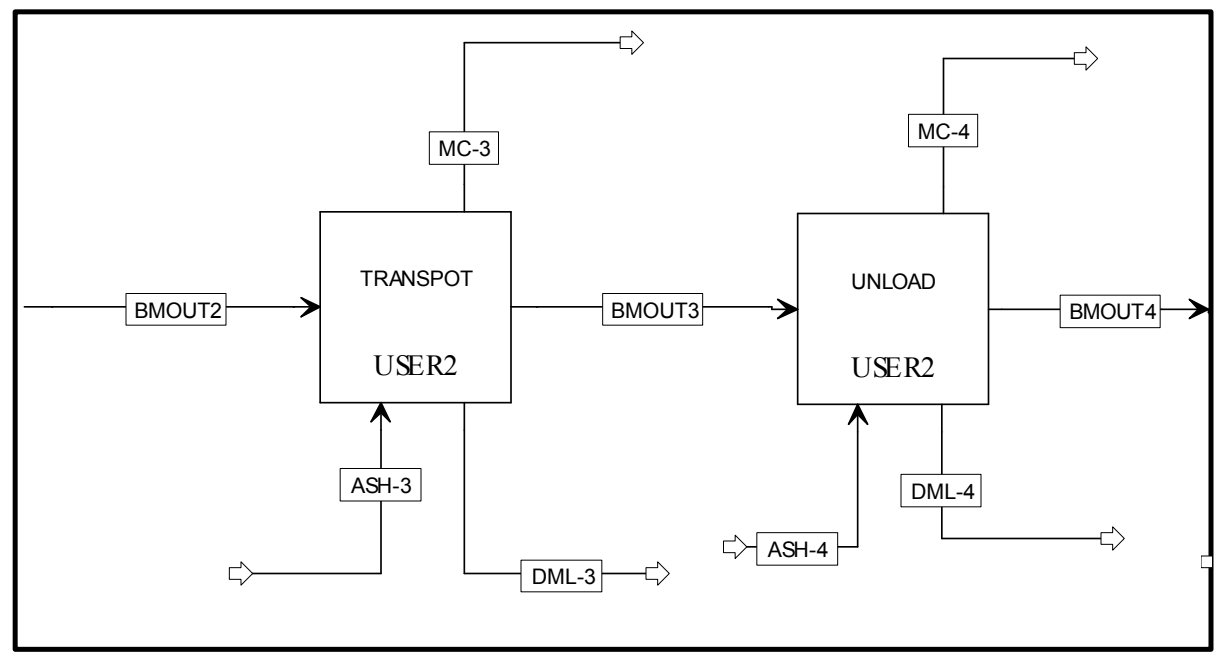

Figure K-3. Detailed process flow diagram for area K200 - Transport. 

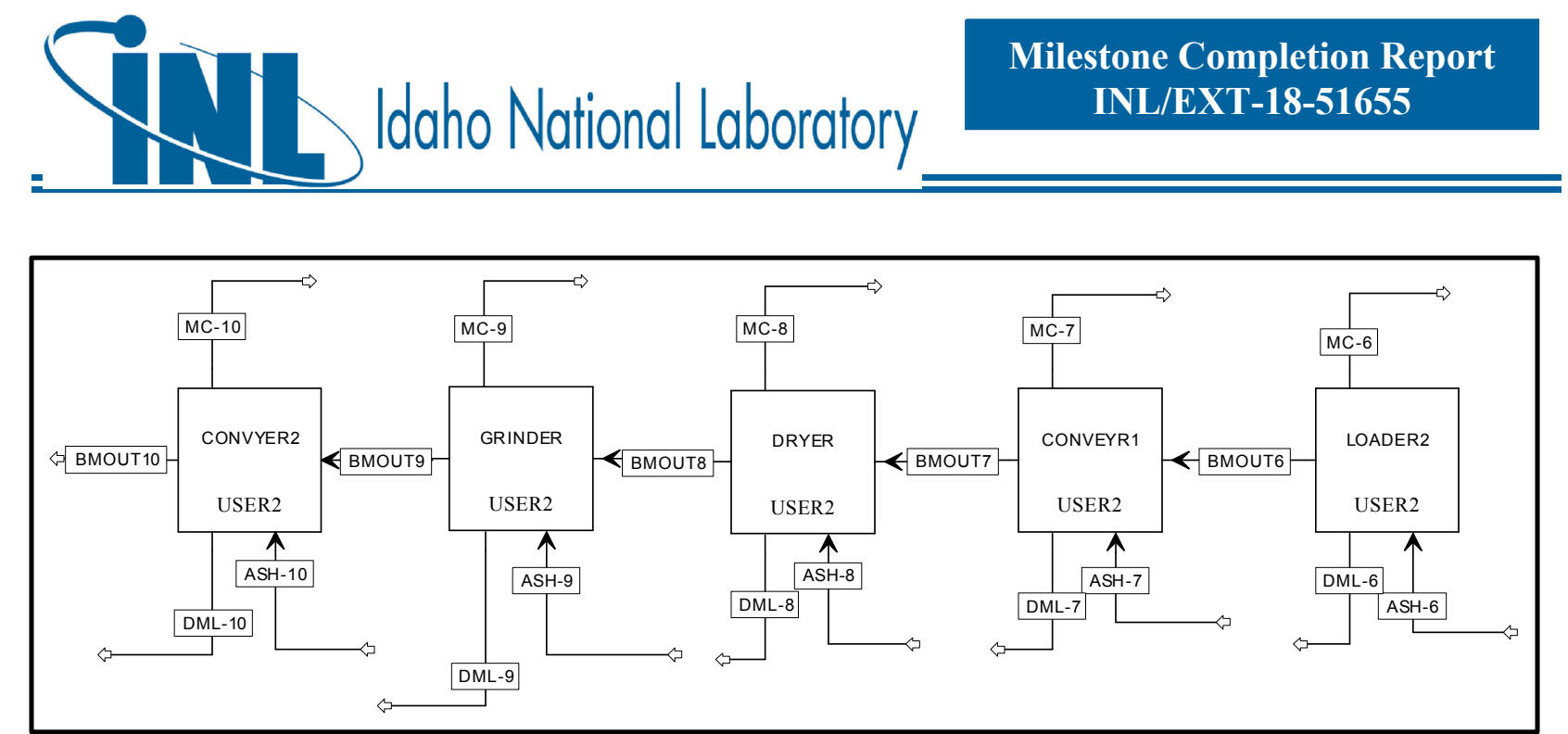

Figure K-4. Detailed process flow diagram for area K300 - Preprocessing - Drying \& Grinding. 


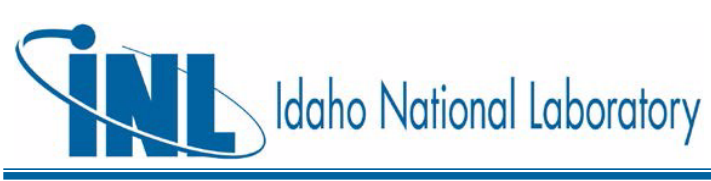

Milestone Completion

Report INL/EXT-18-

Table K-1. Forest residue Aspen Plus mass balances for the Algae-Hydrothermal Liquefaction Pathway (AHTL) SOT.

\begin{tabular}{|c|c|c|c|c|c|c|c|c|c|c|c|c|}
\hline Component & Unit & BIOMIN & DML-1 & MC-1 & BMOUT1 & DML-2 & MC-2 & BMOUT2 & $\begin{array}{c}\text { DML- } \\
3\end{array}$ & $\begin{array}{c}\text { MC- } \\
3\end{array}$ & BMOUT3 & $\begin{array}{c}\text { DML- } \\
4\end{array}$ \\
\hline $\begin{array}{l}\text { Overall Flow (moisture } \\
\text { and dry matter) }\end{array}$ & $\mathrm{kg} / \mathrm{hr}$ & 17,790 & 0 & 0 & 17,790 & 623 & 846 & 16,321 & 0 & 0 & 16,321 & 0 \\
\hline Moisture Flow & $\mathrm{kg} / \mathrm{hr}$ & 5,337 & 0 & 0 & 5,337 & 0 & 846 & 4,491 & 0 & 0 & 4,491 & 0 \\
\hline Total Flow (dry matter) & $\mathrm{kg} / \mathrm{hr}$ & 12,453 & 0 & 0 & 12,453 & 623 & 0 & 11,830 & 0 & 0 & 11,830 & 0 \\
\hline C6 & $\mathrm{kg} / \mathrm{hr}$ & 4,981 & 0 & 0 & 4,981 & 249 & 0 & 4,732 & 0 & 0 & 4,732 & 0 \\
\hline C5 & $\mathrm{kg} / \mathrm{hr}$ & 3,362 & 0 & 0 & 3,362 & 168 & 0 & 3,194 & 0 & 0 & 3,194 & 0 \\
\hline LIGNIN & $\mathrm{kg} / \mathrm{hr}$ & 3,362 & 0 & 0 & 3,362 & 168 & 0 & 3,194 & 0 & 0 & 3,194 & 0 \\
\hline ASH & $\mathrm{kg} / \mathrm{hr}$ & 124 & 0 & 0 & 124 & 6 & 0 & 118 & 0 & 0 & 118 & 0 \\
\hline PROTEIN & $\mathrm{kg} / \mathrm{hr}$ & 0 & 0 & 0 & 0 & 0 & 0 & 0 & 0 & 0 & 0 & 0 \\
\hline EXTRACTIVES & $\mathrm{kg} / \mathrm{hr}$ & 623 & 0 & 0 & 623 & 31 & 0 & 592 & 0 & 0 & 592 & 0 \\
\hline OTHERS & $\mathrm{kg} / \mathrm{hr}$ & 0 & 0 & 0 & 0 & 0 & 0 & 0 & 0 & 0 & 0 & 0 \\
\hline Temperature & K & 298 & 298 & 298 & 298 & 298 & 298 & 298 & 298 & 298 & 298 & 298 \\
\hline Pressure & $\mathrm{atm}$ & 1 & 1 & 1 & 1 & 1 & 1 & 1 & 1 & 1 & 1 & 1 \\
\hline Vapor Frac & & 0 & 0 & 0 & 0 & 0 & 0 & 0 & 0 & 0 & 0 & 0 \\
\hline
\end{tabular}


Milestone Completion

Report INL/EXT-18-

Table K-1. Continued

\begin{tabular}{|c|c|c|c|c|c|c|c|c|c|c|c|}
\hline Component & Unit & $\mathrm{MC}-4$ & BMOUT4 & DML-5 & MC-5 & BMOUT5 & DML-6 & MC-6 & BMOUT6 & DML-7 & MC-7 \\
\hline $\begin{array}{l}\text { Overall Flow (moisture } \\
\text { and dry matter) }\end{array}$ & $\mathrm{kg} / \mathrm{hr}$ & 0 & 16,321 & 0 & 0 & 16,321 & 0 & 0 & 16,321 & 0 & 0 \\
\hline Moisture Flow & $\mathrm{kg} / \mathrm{hr}$ & 0 & 4,491 & 0 & 0 & 4,491 & 0 & 0 & 4,491 & 0 & 0 \\
\hline Total Flow (dry matter) & $\mathrm{kg} / \mathrm{hr}$ & 0 & 11,830 & 0 & 0 & 11,830 & 0 & 0 & 11,830 & 0 & 0 \\
\hline C6 & $\mathrm{kg} / \mathrm{hr}$ & 0 & 4,732 & 0 & 0 & 4,732 & 0 & 0 & 4,732 & 0 & 0 \\
\hline C5 & $\mathrm{kg} / \mathrm{hr}$ & 0 & 3,194 & 0 & 0 & 3,194 & 0 & 0 & 3,194 & 0 & 0 \\
\hline LIGNIN & $\mathrm{kg} / \mathrm{hr}$ & 0 & 3,194 & 0 & 0 & 3,194 & 0 & 0 & 3,194 & 0 & 0 \\
\hline ASH & $\mathrm{kg} / \mathrm{hr}$ & 0 & 118 & 0 & 0 & 118 & 0 & 0 & 118 & 0 & 0 \\
\hline PROTEIN & $\mathrm{kg} / \mathrm{hr}$ & 0 & 0 & 0 & 0 & 0 & 0 & 0 & 0 & 0 & 0 \\
\hline EXTRACTIVES & $\mathrm{kg} / \mathrm{hr}$ & 0 & 592 & 0 & 0 & 592 & 0 & 0 & 592 & 0 & 0 \\
\hline OTHERS & $\mathrm{kg} / \mathrm{hr}$ & 0 & 0 & 0 & 0 & 0 & 0 & 0 & 0 & 0 & 0 \\
\hline Temperature & K & 298 & 298 & 298 & 298 & 298 & 298 & 298 & 298 & 298 & 298 \\
\hline Pressure & $\mathrm{atm}$ & 1 & 1 & 1 & 1 & 1 & 1 & 1 & 1 & 1 & 1 \\
\hline Vapor Frac & & 0 & 0 & 0 & 0 & 0 & 0 & 0 & 0 & 0 & 0 \\
\hline
\end{tabular}


Table K-1. Continued

\begin{tabular}{|c|c|c|c|c|c|c|c|c|c|c|c|}
\hline Component & Unit & BMOUT7 & $\begin{array}{l}\text { DML- } \\
8\end{array}$ & MC-8 & BMOUT8 & DML-9 & MC-9 & BMOUT9 & DML-10 & MC-10 & BMOUT10 \\
\hline $\begin{array}{l}\text { Overall Flow (moisture } \\
\text { and dry matter) }\end{array}$ & $\mathrm{kg} / \mathrm{hr}$ & 16,321 & 0 & 3,176 & 13,146 & 237 & 26 & 12,883 & 0 & 0 & 12,883 \\
\hline Moisture Flow & $\mathrm{kg} / \mathrm{hr}$ & 4,491 & 0 & 3,176 & 1,316 & 0 & 26 & 1,289 & 0 & 0 & 1,289 \\
\hline Total Flow (dry matter) & $\mathrm{kg} / \mathrm{hr}$ & 11,830 & 0 & 0 & 11,830 & 237 & 0 & 11,594 & 0 & 0 & 11,594 \\
\hline C6 & $\mathrm{kg} / \mathrm{hr}$ & 4,732 & 0 & 0 & 4,732 & 95 & 0 & 4,637 & 0 & 0 & 4,637 \\
\hline C5 & $\mathrm{kg} / \mathrm{hr}$ & 3,194 & 0 & 0 & 3,194 & 64 & 0 & 3,130 & 0 & 0 & 3,130 \\
\hline LIGNIN & $\mathrm{kg} / \mathrm{hr}$ & 3,194 & 0 & 0 & 3,194 & 64 & 0 & 3,130 & 0 & 0 & 3,130 \\
\hline ASH & $\mathrm{kg} / \mathrm{hr}$ & 118 & 0 & 0 & 118 & 2 & 0 & 116 & 0 & 0 & 116 \\
\hline PROTEIN & $\mathrm{kg} / \mathrm{hr}$ & 0 & 0 & 0 & 0 & 0 & 0 & 0 & 0 & 0 & 0 \\
\hline EXTRACTIVES & $\mathrm{kg} / \mathrm{hr}$ & 592 & 0 & 0 & 592 & 12 & 0 & 580 & 0 & 0 & 580 \\
\hline OTHERS & $\mathrm{kg} / \mathrm{hr}$ & 0 & 0 & 0 & 0 & 0 & 0 & 0 & 0 & 0 & 0 \\
\hline Temperature & $\mathrm{K}$ & 298 & 298 & 298 & 298 & 298 & 298 & 298 & 298 & 298 & 298 \\
\hline Pressure & atm & 1 & 1 & 1 & 1 & 1 & 1 & 1 & 1 & 1 & 1 \\
\hline Vapor Frac & & 0 & 0 & 0 & 0 & 0 & 0 & 0 & 0 & 0 & 0 \\
\hline
\end{tabular}




\section{APPENDIX L - Process Flow Diagrams and Mass Balances for Supply of Logging Residues to AHTL - 2022 Projection}

High-level stream table information from Aspen Plus modeling output follows, for key streams associated with each process operation area. This is followed by high-level PFDs for the associated process areas. Space for stream tables was limited; below is a key to lumped components. As the stream table information focuses primarily on the high-level overall process and does not include every individual modeled stream within each process area, mass balance closure around a given unit area may not be $100 \%$.

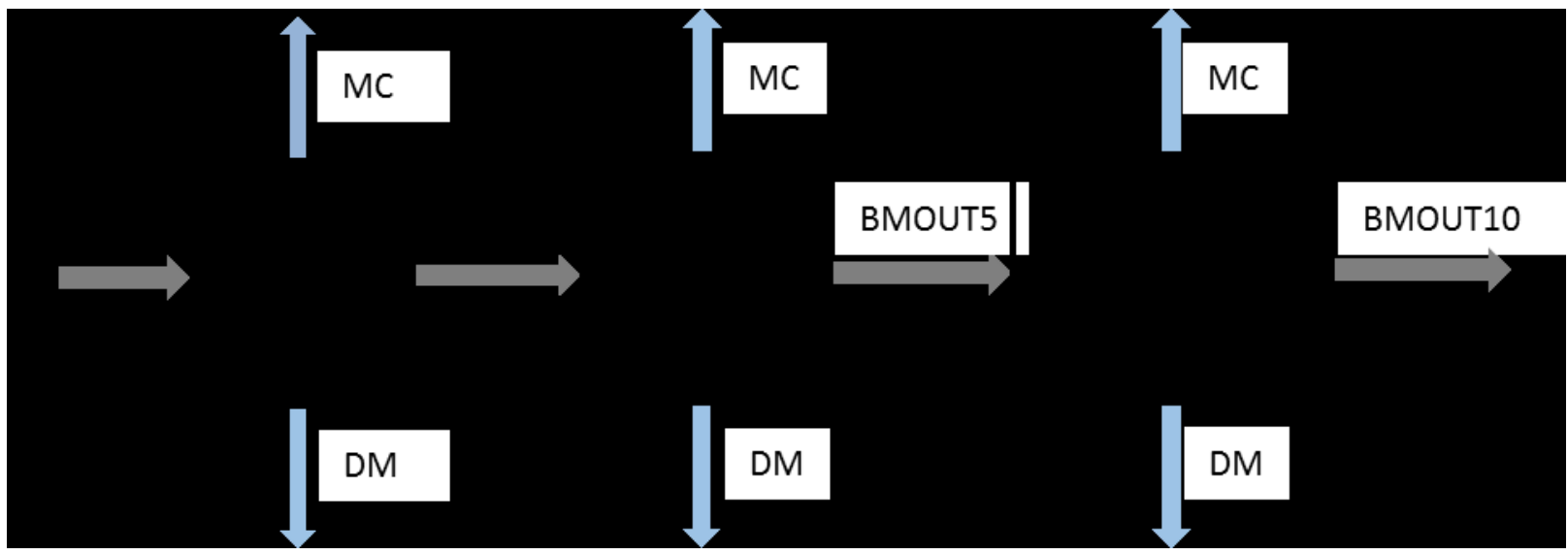

Figure L-1. High-level flowsheet showing key process areas for the forest residue blendstock in the Algae-Hydrothermal Liquefaction Pathway (AHTL) 2022 Projection. 


\section{Milestone Completion Report}

Idaho National Laboratory

\section{INL/EXT-18-51655}

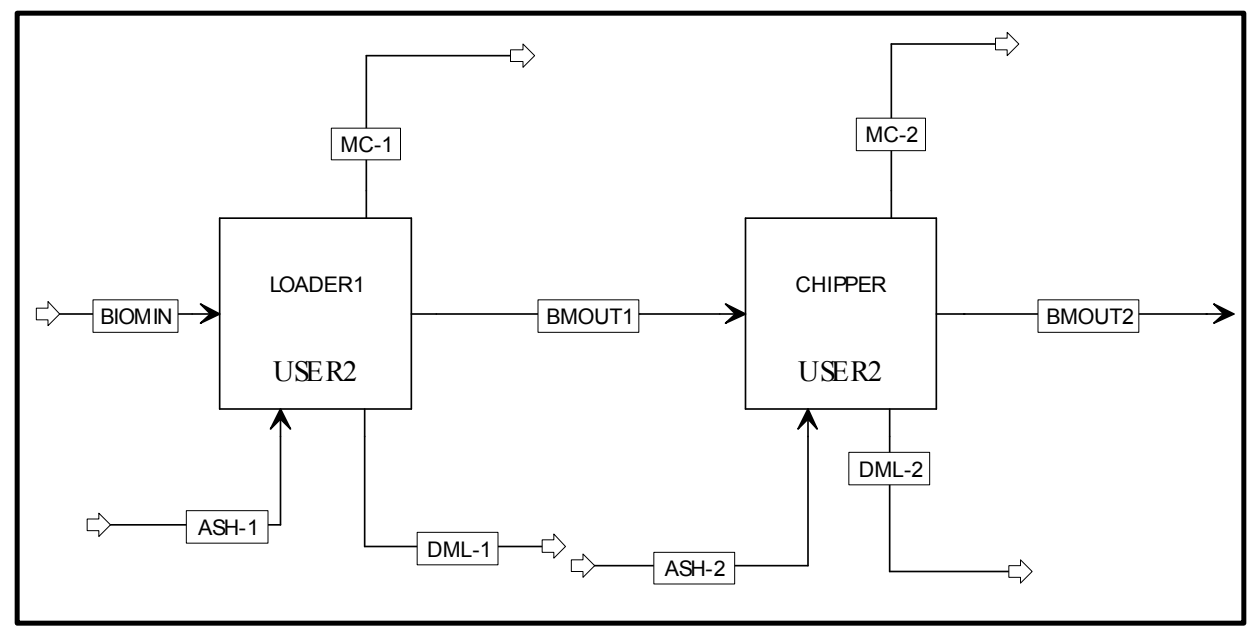

Figure L-2. Detailed process flow diagram for area L100 - Harvesting.

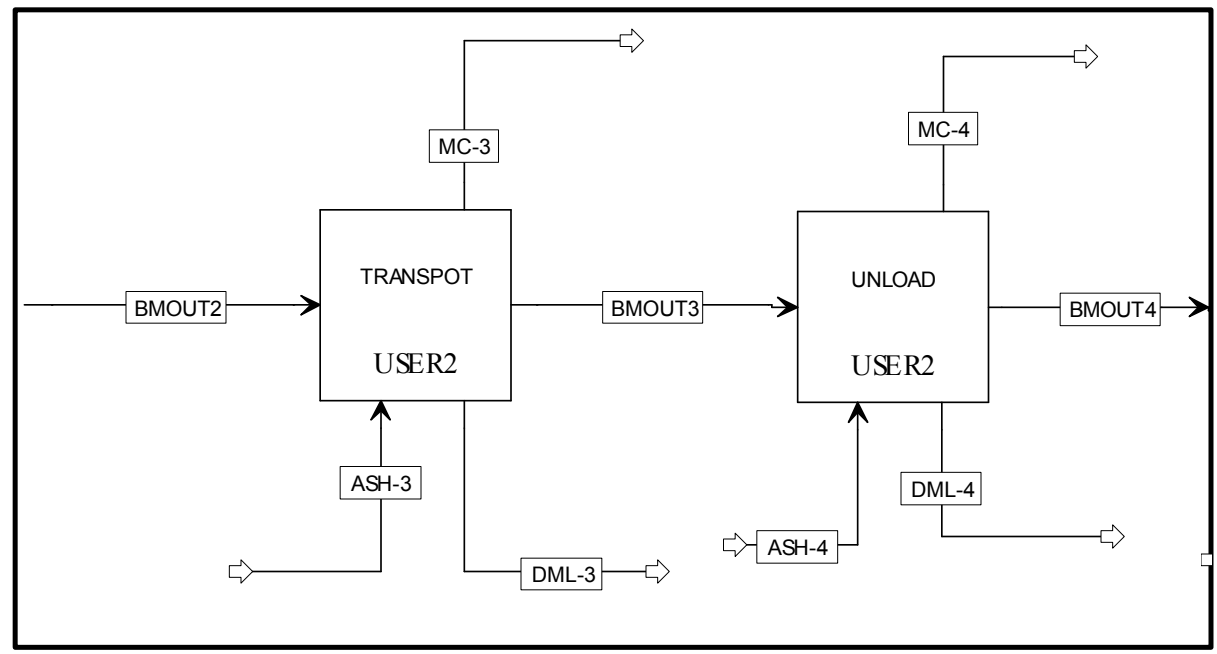

Figure L-3. Detailed process flow diagram for area L200 - Transport. 

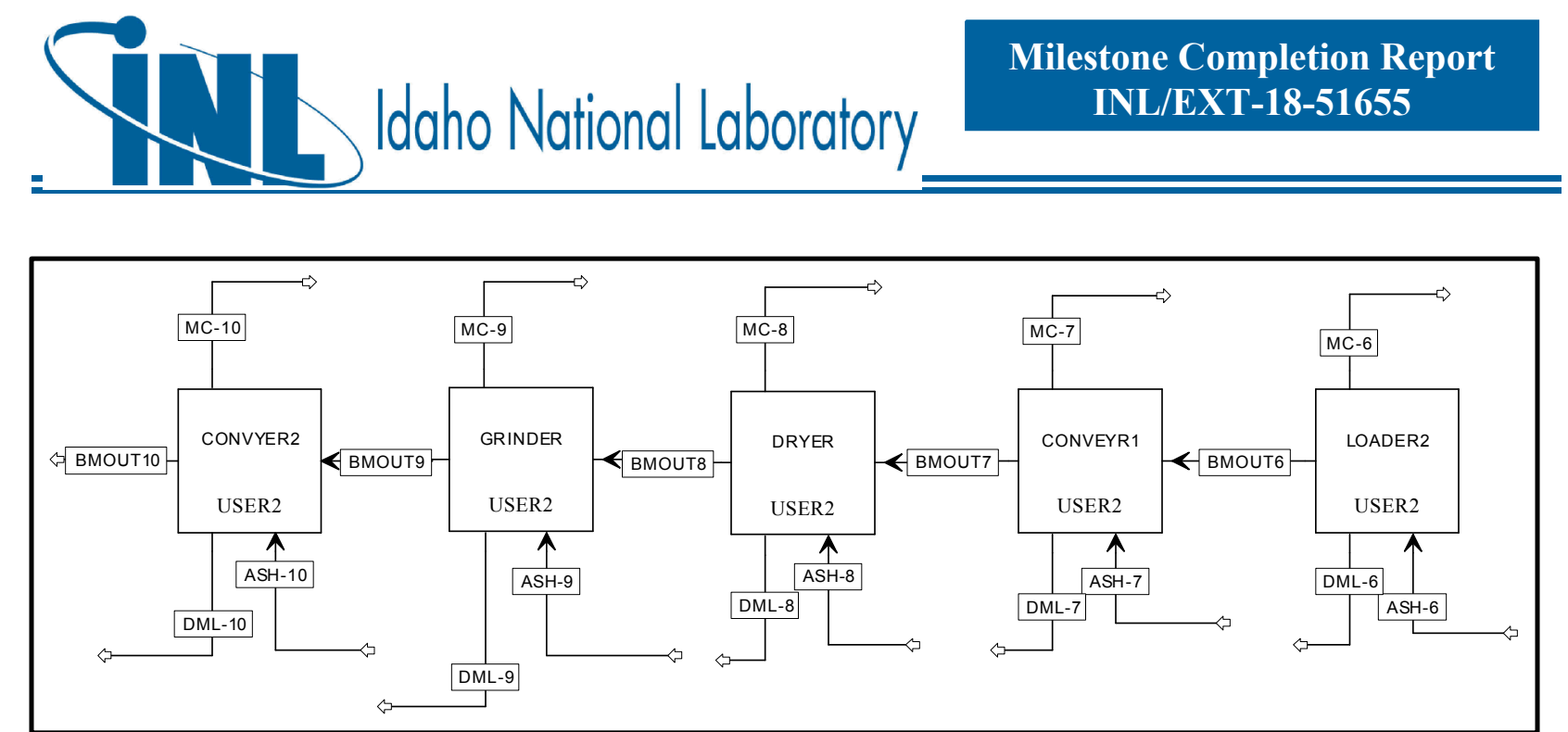

Figure L-4. Detailed process flow diagram for area L300 - Preprocessing - Drying \& Grinding. 
TII Idaho National Laboratory

Milestone Completion

Report INL/EXT-18-

Table L-1. Forest residue Aspen Plus mass balances for the Algae-Hydrothermal Liquefaction Pathway (AHTL) 2022

Projection.

\begin{tabular}{|c|c|c|c|c|c|c|c|c|c|c|c|c|}
\hline Component & Unit & BIOMIN & DML-1 & MC-1 & BMOUT1 & DML-2 & MC-2 & BMOUT2 & $\begin{array}{l}\text { DML- } \\
3\end{array}$ & MC- & BMOUT3 & $\underset{4}{\text { DML- }}$ \\
\hline $\begin{array}{l}\text { Overall Flow (moisture } \\
\text { and dry matter) }\end{array}$ & $\mathrm{kg} / \mathrm{hr}$ & 17,790 & 0 & 0 & 17,790 & 623 & 846 & 16,321 & 0 & 0 & 16,321 & 0 \\
\hline Moisture Flow & $\mathrm{kg} / \mathrm{hr}$ & 5,337 & 0 & 0 & 5,337 & 0 & 846 & 4,491 & 0 & 0 & 4,491 & 0 \\
\hline Total Flow (dry matter) & $\mathrm{kg} / \mathrm{hr}$ & 12,453 & 0 & 0 & 12,453 & 623 & 0 & 11,830 & 0 & 0 & 11,830 & 0 \\
\hline C6 & $\mathrm{kg} / \mathrm{hr}$ & 4,981 & 0 & 0 & 4,981 & 249 & 0 & 4,732 & 0 & 0 & 4,732 & 0 \\
\hline C5 & $\mathrm{kg} / \mathrm{hr}$ & 3,362 & 0 & 0 & 3,362 & 168 & 0 & 3,194 & 0 & 0 & 3,194 & 0 \\
\hline LIGNIN & $\mathrm{kg} / \mathrm{hr}$ & 3,362 & 0 & 0 & 3,362 & 168 & 0 & 3,194 & 0 & 0 & 3,194 & 0 \\
\hline ASH & $\mathrm{kg} / \mathrm{hr}$ & 124 & 0 & 0 & 124 & 6 & 0 & 118 & 0 & 0 & 118 & 0 \\
\hline PROTEIN & $\mathrm{kg} / \mathrm{hr}$ & 0 & 0 & 0 & 0 & 0 & 0 & 0 & 0 & 0 & 0 & 0 \\
\hline EXTRACTIVES & $\mathrm{kg} / \mathrm{hr}$ & 623 & 0 & 0 & 623 & 31 & 0 & 592 & 0 & 0 & 592 & 0 \\
\hline OTHERS & $\mathrm{kg} / \mathrm{hr}$ & 0 & 0 & 0 & 0 & 0 & 0 & 0 & 0 & 0 & 0 & 0 \\
\hline Temperature & $\mathrm{K}$ & 298 & 298 & 298 & 298 & 298 & 298 & 298 & 298 & 298 & 298 & 298 \\
\hline Pressure & atm & 1 & 1 & 1 & 1 & 1 & 1 & 1 & 1 & 1 & 1 & 1 \\
\hline Vapor Frac & & 0 & 0 & 0 & 0 & 0 & 0 & 0 & 0 & 0 & 0 & 0 \\
\hline
\end{tabular}


Milestone Completion

Report INL/EXT-18-

Table L-1. Continued

\begin{tabular}{|c|c|c|c|c|c|c|c|c|c|c|c|}
\hline Component & Unit & $\mathrm{MC}-4$ & BMOUT4 & DML-5 & MC-5 & BMOUT5 & DML-6 & MC-6 & BMOUT6 & DML-7 & MC-7 \\
\hline $\begin{array}{l}\text { Overall Flow (moisture } \\
\text { and dry matter) }\end{array}$ & $\mathrm{kg} / \mathrm{hr}$ & 0 & 16,321 & 0 & 0 & 16,321 & 0 & 0 & 16,321 & 0 & 0 \\
\hline Moisture Flow & $\mathrm{kg} / \mathrm{hr}$ & 0 & 4,491 & 0 & 0 & 4,491 & 0 & 0 & 4,491 & 0 & 0 \\
\hline Total Flow (dry matter) & $\mathrm{kg} / \mathrm{hr}$ & 0 & 11,830 & 0 & 0 & 11,830 & 0 & 0 & 11,830 & 0 & 0 \\
\hline C6 & $\mathrm{kg} / \mathrm{hr}$ & 0 & 4,732 & 0 & 0 & 4,732 & 0 & 0 & 4,732 & 0 & 0 \\
\hline C5 & $\mathrm{kg} / \mathrm{hr}$ & 0 & 3,194 & 0 & 0 & 3,194 & 0 & 0 & 3,194 & 0 & 0 \\
\hline LIGNIN & $\mathrm{kg} / \mathrm{hr}$ & 0 & 3,194 & 0 & 0 & 3,194 & 0 & 0 & 3,194 & 0 & 0 \\
\hline ASH & $\mathrm{kg} / \mathrm{hr}$ & 0 & 118 & 0 & 0 & 118 & 0 & 0 & 118 & 0 & 0 \\
\hline PROTEIN & $\mathrm{kg} / \mathrm{hr}$ & 0 & 0 & 0 & 0 & 0 & 0 & 0 & 0 & 0 & 0 \\
\hline EXTRACTIVES & $\mathrm{kg} / \mathrm{hr}$ & 0 & 592 & 0 & 0 & 592 & 0 & 0 & 592 & 0 & 0 \\
\hline OTHERS & $\mathrm{kg} / \mathrm{hr}$ & 0 & 0 & 0 & 0 & 0 & 0 & 0 & 0 & 0 & 0 \\
\hline Temperature & $\mathrm{K}$ & 298 & 298 & 298 & 298 & 298 & 298 & 298 & 298 & 298 & 298 \\
\hline Pressure & $\mathrm{atm}$ & 1 & 1 & 1 & 1 & 1 & 1 & 1 & 1 & 1 & 1 \\
\hline Vapor Frac & & 0 & 0 & 0 & 0 & 0 & 0 & 0 & 0 & 0 & 0 \\
\hline
\end{tabular}


Milestone Completion

Report INL/EXT-18-

Table L-1. Continued

\begin{tabular}{|c|c|c|c|c|c|c|c|c|c|c|c|}
\hline Component & Unit & BMOUT7 & $\begin{array}{c}\text { DML- } \\
8\end{array}$ & MC-8 & BMOUT8 & DML-9 & MC-9 & BMOUT9 & DML-10 & MC-10 & BMOUT10 \\
\hline $\begin{array}{l}\text { Overall Flow (moisture } \\
\text { and dry matter) }\end{array}$ & $\mathrm{kg} / \mathrm{hr}$ & 16,321 & 0 & 3,176 & 13,146 & 237 & 26 & 12,883 & 0 & 0 & 12,883 \\
\hline Moisture Flow & $\mathrm{kg} / \mathrm{hr}$ & 4,491 & 0 & 3,176 & 1,316 & 0 & 26 & 1,289 & 0 & 0 & 1,289 \\
\hline Total Flow (dry matter) & $\mathrm{kg} / \mathrm{hr}$ & 11,830 & 0 & 0 & 11,830 & 237 & 0 & 11,594 & 0 & 0 & 11,594 \\
\hline C6 & $\mathrm{kg} / \mathrm{hr}$ & 4,732 & 0 & 0 & 4,732 & 95 & 0 & 4,637 & 0 & 0 & 4,637 \\
\hline C5 & $\mathrm{kg} / \mathrm{hr}$ & 3,194 & 0 & 0 & 3,194 & 64 & 0 & 3,130 & 0 & 0 & 3,130 \\
\hline LIGNIN & $\mathrm{kg} / \mathrm{hr}$ & 3,194 & 0 & 0 & 3,194 & 64 & 0 & 3,130 & 0 & 0 & 3,130 \\
\hline ASH & $\mathrm{kg} / \mathrm{hr}$ & 118 & 0 & 0 & 118 & 2 & 0 & 116 & 0 & 0 & 116 \\
\hline PROTEIN & $\mathrm{kg} / \mathrm{hr}$ & 0 & 0 & 0 & 0 & 0 & 0 & 0 & 0 & 0 & 0 \\
\hline EXTRACTIVES & $\mathrm{kg} / \mathrm{hr}$ & 592 & 0 & 0 & 592 & 12 & 0 & 580 & 0 & 0 & 580 \\
\hline OTHERS & $\mathrm{kg} / \mathrm{hr}$ & 0 & 0 & 0 & 0 & 0 & 0 & 0 & 0 & 0 & 0 \\
\hline Temperature & K & 298 & 298 & 298 & 298 & 298 & 298 & 298 & 298 & 298 & 298 \\
\hline Pressure & $\mathrm{atm}$ & 1 & 1 & 1 & 1 & 1 & 1 & 1 & 1 & 1 & 1 \\
\hline Vapor Frac & & 0 & 0 & 0 & 0 & 0 & 0 & 0 & 0 & 0 & 0 \\
\hline
\end{tabular}


